\title{
A gyülölet-büncselekményekkel szembeni fellépés jelentősége és lehetőségei
}

Nemzetközi és hazai jogalkotási, jogalkalmazási és adatgyüjtési kérdések

$\mathrm{PhD}$ értekezés

Témavezető: Dr. Tóth Judit tanszékvezető egyetemi docens

SZTE Állam- és Jogtudományi Kar, Alkotmányjogi Tanszék

Írta: Dinók Henriett Éva

SZEGEDI TUDOMÁNYEGYETEM

ÁLLAM- ÉS JOGTUDOMÁNYI KAR

ALKOTMÁNYJOGI TANSZÉK 


\section{Tartalom}

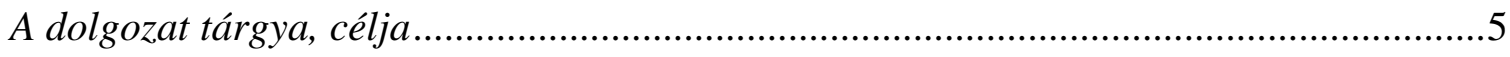

A vizsgált országok kiválasztása során irányadó szempontok ........................................8

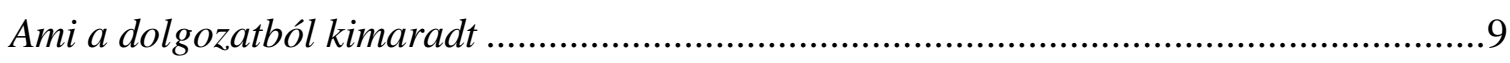

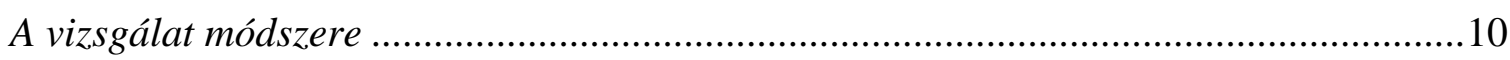

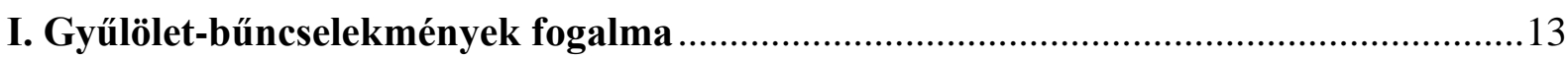

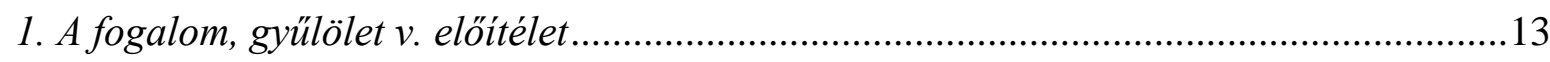

2. Elhatárolás más elöitélet vezérelte cselekményektöl ....................................................16

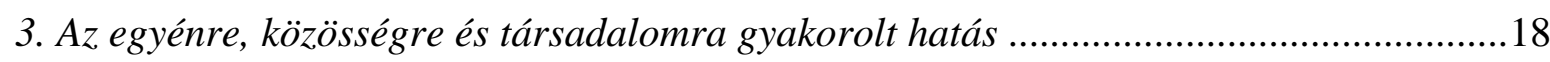

3.1. Gyülölet-büncselekmények az egyéni áldozat szintjén ..........................................18

3.2. Gyülölet-büncselekmények második szintje, a védett csoport. Gyülöletbüncselekmények, mint üzenet-büncselekmények.....................................................21

3.3. A gyülölet-bűncselekmények hatásainak harmadik dimenziója, a társadalmi

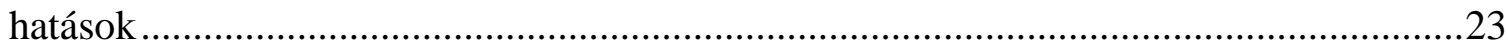

3.4. Gyülölet-büncselekmények az emberi jogok szintjén ..............................................28

3.5. A megkülönböztetett figyelem indokai ................................................................ 34

II. A gyülölet-büncselekmények szabályozásának általános kérdései - érvek a

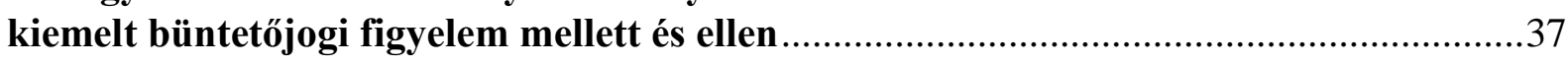

1. Egy társadalmi probléma visszaszorítása büntetöjogi eszközökkel ................................37

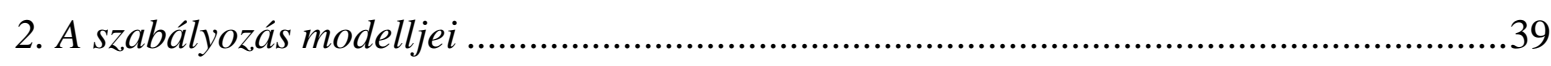

2.1. A szabályozási modellek büntetőjog-tudományi csoportosítása ................................39

2.2. A szabályozási modellek elterjedtsége, tartalma, valamint az egyes modellek

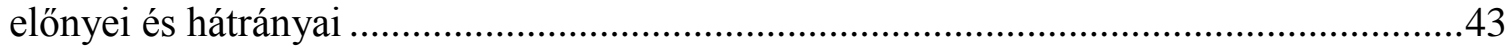

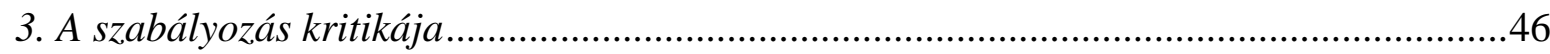

3.1. A gyülölet-büncselekmények és alapcselekmények egyénre, védett csoportra és társadalomra gyakorolt hatásával kapcsolatos érvek ....................................................47

3.2. Alkotmányellenesség, a szólásszabadság határa .................................................... 51

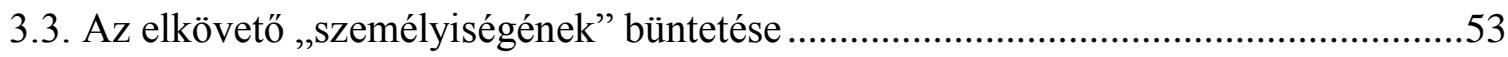

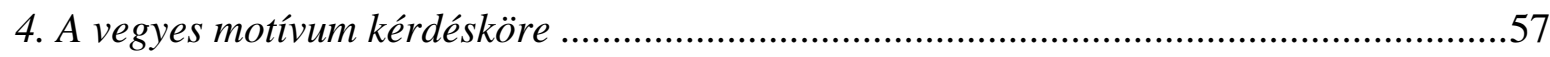

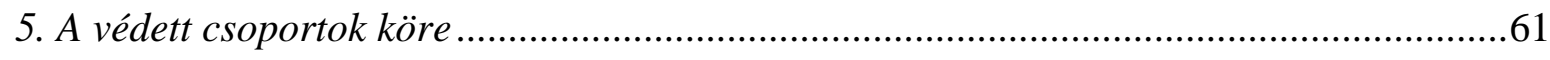

5.1. A szabályozás kisebbség- vagy identitásvédő intézkedés jellege .............................61

5.2. A védett csoportok szabályozásának módszerei - Nyílt vagy zárt végü lista .............66

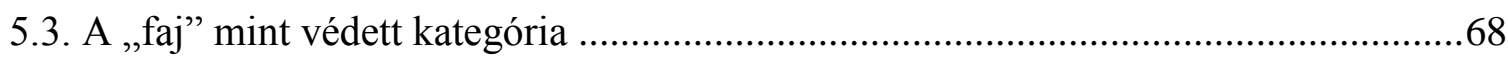

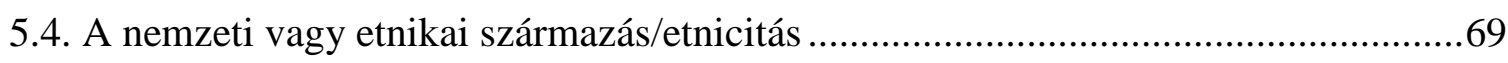




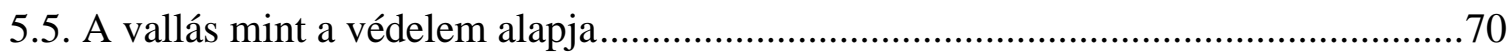

5.6. Fogyatékosság mint védett tulajdonság .............................................................. 70

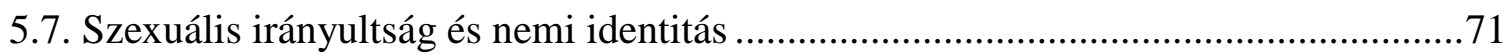

III. Magyarország nemzetközi jogi és európai uniós kötelezettségei a gyülöletbüncselekményekkel szembeni fellépésre vonatkozóan .................................................74

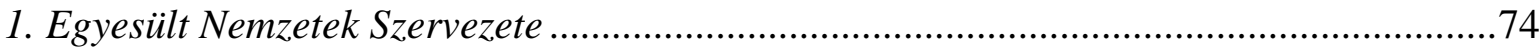

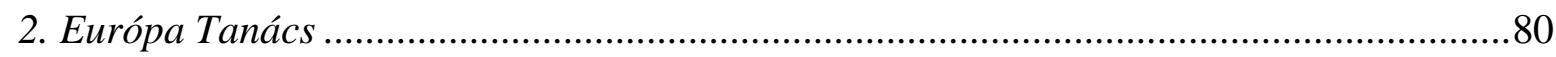

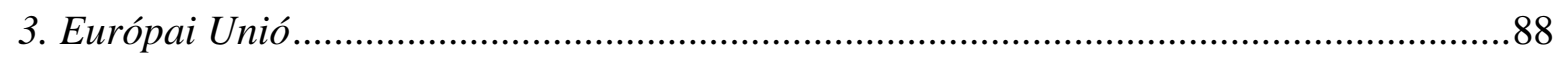

4. Európai Biztonsági és Együttmüködési Szervezet ......................................................95

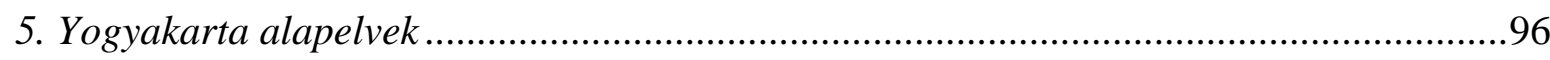

IV. Szabályozási és jogalkalmazási nemzetközi kitekintés ..........................................99

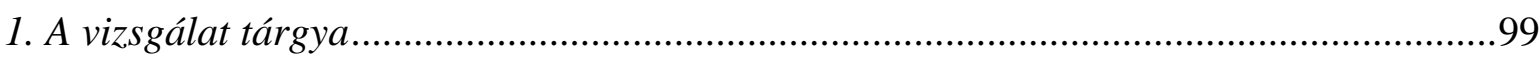

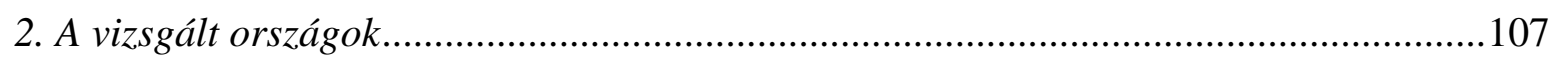

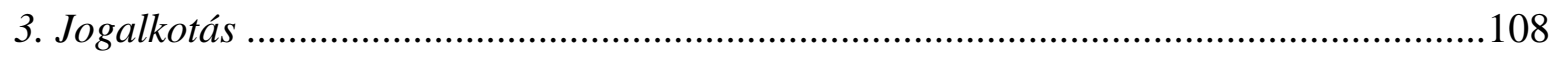

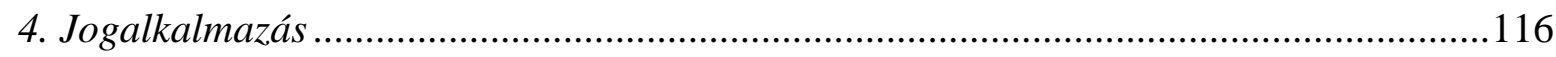

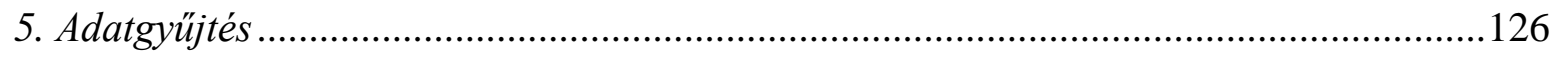

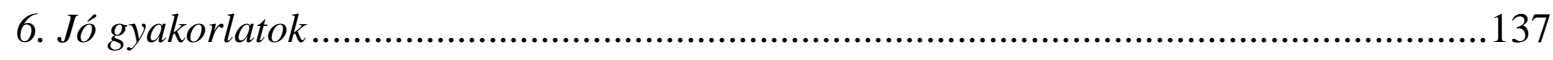

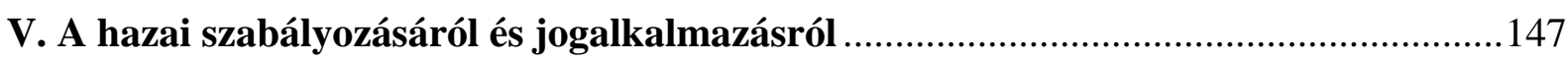

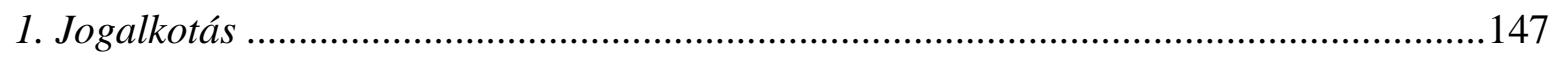

1.1. A sui generis tényállás - a tényállás kialakulása...................................................149

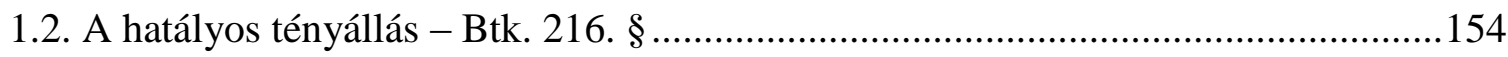

1.2.1. Btk. 216. § (1) bekezdés, a kihívóan közösségellenes magatartással megvalósított közösség tagja elleni erőszak …….....................................................155

1.2.2. Btk. 216. § (2) bekezdés, a bántalmazással vagy kényszerítéssel elkövetett

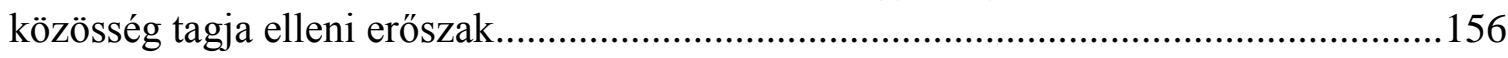

1.2.3. Btk. 216. § (3) bekezdés, a közösség tagja elleni erőszak minősített esetei...........160

1.2.4. Btk. 216. § (4) bekezdés, a közösség tagja elleni erőszak elökélszülete .................162

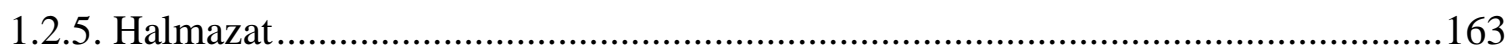

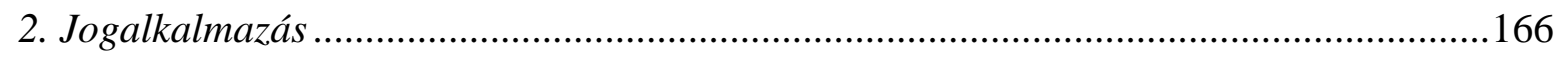

2.1. Hatáskör, gyülölet-büncselekmények elleni szakvonal és ügyészségi protokoll .....166

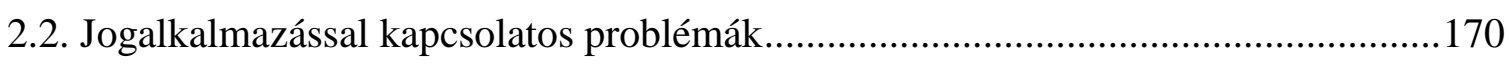

2.2.1. Btk. 216. § (1) bekezdéssel kapcsolatos jogalkalmazási problémák......................174

2.2.2. Btk. 216. § (2) bekezdéssel kapcsolatos jogalkalmazási problémák......................184

2.2.3. Hatáskörrel kapcsolatban felmerülő problémák .................................................186

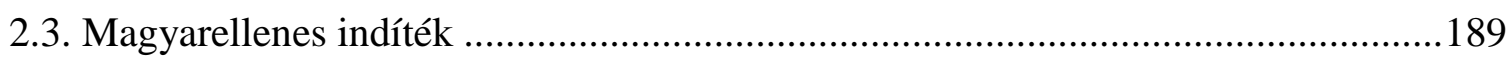

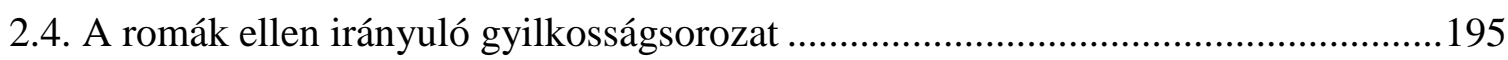




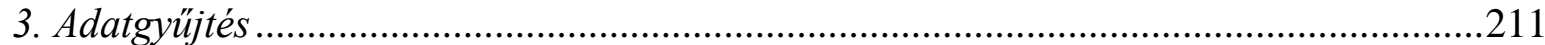

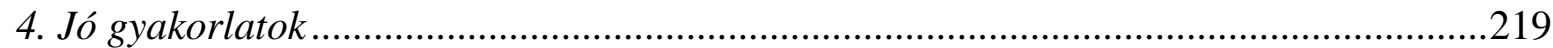

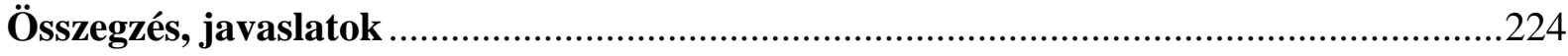

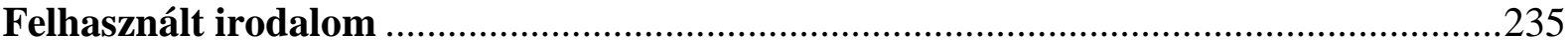




\section{A gyülölet-büncselekményekkel szembeni fellépés jelentősége és lehetőségei \\ Nemzetközi és hazai jogalkotási, jogalkalmazási és adatgyüjtési kérdések}

\section{A dolgozat tárgya, célja}

Munkám - a magyar jogrendszerben és közbeszédben viszonylag új keletü - gyülöletbüncselekmények jelenségét és szabályozását vizsgálja. A dolgozat kiinduló pontja, hogy a gyülöletvezérelte büncselekmények számos szempontból megkülönböztethetőek más büncselekményektől. E jelenség hatásai három különböző szinten ragadhatók meg: az egyén, azaz a sértett; a közösség, azaz a védett csoport; valamint a társadalom szintjén. A gyülöletmotiválta büncselekmények súlyosabb hatásokkal járhatnak mind az egyénre, mind a közösségre nézve pszichés-érzelmi, emberi jogi, társadalmi, gazdasági szempontból és üzenet-büncselekmény jellegükből fakadóan nem csupán az áldozatra és az érintett csoportra nézve fejtik ki hatásukat. A gyülölet-büncselekmények az egész társadalomra nézve komoly következményekkel járhatnak: magukban hordozzák annak veszélyét, hogy a csoportok között ellenségeskedés alakulhat ki, aminek következtében elszabadulhatnak az indulatok.

A szabályozással kapcsolatban gyakran hivatkozott érv, hogy megalkotásának nem csupán a gyülölet-büncselekmények visszaszorítása a célja, hanem egy toleránsabb társadalmi közeg megteremtése is; azáltal, hogy a különböző csoportok közötti erőszakot társadalmi problémaként kezelik, és ezzel egyfajta üzenetet küld az áldozat, az áldozati csoport, az elkövető és a társadalom számára. ${ }^{1}$ Így a gyülöletbüncselekményekkel kapcsolatos szabályozást a rasszizmussal, a homofóbiával, az antiszemitizmussal és hasonló jelenségekkel szembeni eszközként használják, azaz nem csupán a konkrét erőszakos cselekményekben manifesztálódott intolerancia szankcionálására, hanem magának az intoleráns társadalmi közegnek a „kezelésére” is. Persze azzal kapcsolatban lehetnek és léteznek is szkeptikus nézetek, hogy szükséges-e üzenetet küldeni a teljese társadalomnak, de amint Kállai Ernő is rámutatott: a gyülölet-

\footnotetext{
${ }^{1}$ Ld pl.: James B. JACOBS: "The Emergence and Implications of American Hate Crime Jurisprudence" in Barbara Perry (szerk.): Hate and Bias Crime, A Reader (New York: Routledge 2003) 409-426.
} 
büncselekményekkel kapcsolatos veszélyforrásokkal szembeni társadalompolitikai védekezés eszközrendszere természetesen sokrétü és ezen az adekvát büntetőjogi eszközök megválasztása csak szerény részt képvisel. Ennek ellenére az országgyülési biztos már 2011-ben úgy gondolta, hogy „elöállt egy olyan társadalompolitikai helyzet, amikor a büntetökódexnek a jelenleginél jóval egyértelmübben és szigorúbban kell kifejeznie az állam negatív értékítéletét a faji cselekményekkel kapcsolatban". ${ }^{2}$

Tagadhatatlan, hogy a gyülölet-büncselekmények az intolerancia erőszakos megnyilvánulási formái, és erre tekintettel elfogadhatónak tünik azon állítás, hogy hatásai nem csupán az egyéni áldozat tekintetében jelentősek, hanem a védett csoport és a teljes társadalom is érintetté válik, és így hatással lehetnek mind a közösségek közötti kapcsolatokra, mind a társadalmi stabilitásra. Az elöítélet állam általi elítélése fontos üzenetet közvetít az elkövető, a társadalom és áldozat, illetve a védett csoport tagjai felé is: azt hogy az ilyen cselekmények nem megtürtek egy demokratikus társadalom keretei között. ${ }^{3}$ Az egyéni áldozatot ért sérelem elismerésével pedig azt közvetítik, hogy a bünügyi szervek védelmet biztosítanak, mind az áldozat, mind a csoport tagjai számára. Ha pedig elfogadjuk azt a nézetet, hogy a jog - különösen a büntetőjog - kifejezi a társadalmi értékeket, akkor a gyülölet-büncselekmények szabályozása egyaránt jelzi az egyenlőség társadalmi értékének felismerését, támogatását és az előmozdítása iránti szándékot. ${ }^{4}$

A kontinentális jogokban a büntetőjog közvetíti a minimum morált. ${ }^{5}$ Ebből következően a büntetőjog értékvédő, értékteremtő és értékhordozó is. ${ }^{6}$ Ehhez az értékhordozó szerephez pedig azáltal jutott, hogy mindig függött az adott kor közjogi-alkotmányjogi rendszerétől. Éppen ezért és emiatt alakultak ki garanciális szabályai. A modern büntetőjog közjogi és alkotmányjogi függése mellett legitimitását azáltal is megalapozta, hogy a kor kultúrájának szellemét hordozta: a felvilágosodás eszméit, a humanizmust, a liberális toleranciát és a szabadságeszményeket. Korunkban, az

\footnotetext{
${ }^{2}$ Kállai Ernő, a nemzeti és etnikai kisebbségi jogok országgyülési biztosának levele a közigazgatási és igazságügyi miniszterhez. Nek-439/2011. 2011. április 5. 1. http://www.kisebbsegiombudsman.hu/data/files/202083196.pdf (2015. június 26.)

${ }^{3}$ Ld. pl.: Barbara PERRY: „Counting - and Countering - Hate Crime in Europe”, European Journal of Crime, Criminal Law and Criminal Justice Vol. 18 No. 4. 349-367.

${ }^{4}$ Office for Democratic Institutions and Human Rights of OSCE (ODIHR): Hate Crime Laws. A Practical Guide, 2009, 11. www.osce.org/odihr/36426

${ }^{5}$ Belovics [et al.]: Büntetöjog I. - A 2012. évi C. törvény alapján. Budapest: HVG Orac Kiado, 2012.

${ }^{6}$ Bővebben lásd: Németh Imre: „Elmélkedés a büntetendővé nyilvánítás értéktartalmáról” in SzoboszlaiKiss Katalin-Deli Gergely (szerk.): Tanulmányok a 70 éves Bihari Mihály tiszteletére, Györ: UniversitasGyőr Nonprofit Kft., 2013, 361-368.
} 
alkotmányos jogállamok, a jogállami demokráciák korában, az emberi jogi és az alkotmányos alapjogok, amelyek védelme, és amelyek követelményrendszerének beteljesítése a büntetőjog alapvető funkciója. ${ }^{7}$ Mindebből kifolyólag pedig érdemes a büntetőjogra nem csak, mint az elrettentés-megtorlás területére, hanem a társadalmi értékek kinyilvánításának tartományára tekinteni.

A gyülölet-büncselekmények esetében tehát adott egy társadalmi jelenség, amelyre a normatív rendszer reagál valamiképp. Amikor a társadalmi kohézió nem müködik, illetve - a gyülöletvezérelte büncselekmények esetében - a legkevésbé müködik, a büntetőjog végső eszközként, értékvédőként és értékőrzőként vállalja magára az indulatok csatornába terelését. A büntető igazságszolgáltatás pedig az a tevékenység, amelyen keresztül az állam a legnagyobb mértékben beavatkozik az emberek életébe. „Sokat elárul egy társadalomról, egy államról, illetve az igazságszolgáltatás szereplöiröl, hogy hogyan viszonyulnak ennek a tevékenységnek a hibáihoz."8 A kutatás éppen ebből kifolyólag meghatározó szerepet szán a büntetőjognak, de a dolgozat egyben önkorlátozást is végez e ponton. A gyülölet-büncselekmények, illetve az alapjául szolgáló társadalmi problémák vizsgálata áll a középpontban, amelyek tanulmányozásához jelen körülmények között a büntetőjogi megközelítés szolgál alapul, az értékvédő funkcióból eredően. Ebből fakadóan a dolgozat célja annak vizsgálata, hogy az értékőrző jogág megfelelően reagál-e a társadalom problémáira. A büntetőjog fejlesztése legfeljebb másodlagos célként szerepelhet, a kutatás során feltárt anomáliákra vonatkozó ajánlások megfogalmazása révén.

Mindezekre tekintettel a dolgozat elsődleges célja, hogy az említett megkülönböztető szempontokat szem előtt tartva mutassa be a gyülölet-büncselekmények elsősorban hazai és nemzetközi szabályozását, a hazai szabályozáson belül elsődlegesen a Btk. speciális tényállása, a „közösség tagja elleni erőszak” kapcsán felmerülő jogalkotási és jogalkalmazási kérdéseket és anomáliákat -, és e kérdésekre válaszul megoldási javaslatokkal szolgáljon a gyülölet-büncselekmények hatékonyabb megelözése és kezelése tekintetében, figyelembe véve a különféle létező megoldásokat a társadalom, a civil szervezetek és az állam részéről.

\footnotetext{
${ }^{7}$ Szabó András: Recepció és kreativitás a büntetőjogban. http://www.phil-inst.hu/recepcio/htm/7/704.htm (2015. május 5.)

${ }^{8}$ Hack Péter: Az igazságszolgáltatás kudarcai. Vizgyálatok és megoldások az angolszász jogrendszerben. 2007. Az előadás elhangzott a Magyar Büntetőjogi Társaság rendezvényén, 2007. április 19-én. http://www.mbjt.hu/HackPeter20070419.pdf (2015. május 10.)
} 
A dolgozat a következő struktúra szerint épül fel: a dolgozat első felében áttekintem a gyülölet-büncselekmények fogalmával kapcsolatban kialakult különböző nézeteket, valamint e büncselekmények egyénre, közösségre és társadalomra gyakorolt hatásait. Ezt követően a dolgozat azt próbálja meg bemutatni, hogy az adott ország történelmi és társadalmi sajátosságait figyelembe véve, a jogalkotónak mely kérdésekben kell állást foglalni a gyülölet vezérelte büncselekményekre vonatkozó szabályozás kialakítása során, elsősorban az egyes szabályozási modellek és védett csoportok kapcsán. Ehhez kapcsolódóan pedig igyekszik rámutatni az egyes szabályozási modellek előnyeire és hátrányaira, valamint ismerteti a kiemelt büntetőjogi figyelemre vonatkozó különböző pro és kontra nézeteket. Majd elsősorban azokkal a - Magyarország szempontjából jelentőséggel bíró - fontosabb nemzetközi emberi jogi dokumentumokkal és közösségi jogi szabályokkal foglalkozik a dolgozat, amelyek a diszkrimináció különböző formáinak tilalmához és gyülölet-büncselekményekhez kapcsolódnak. A szabályozási és jogalkalmazási nemzetközi kitekintés a különböző nemzeti mintákat ismerteti és hasonlítja össze jogalkotás, jogalkalmazás, hivatalos adatgyüjtési rendszer és jó gyakorlatok szempontjából, annak reményében, hogy a vizsgált országok tapasztalatai a gyülölet-büncselekmények hazai szabályozásának és az azokkal kapcsolatos jogalkalmazás hatékonyságát növelő javaslatok megfogalmazásához is hozzájárulnak.

A dolgozat második nagyobb egységének célja, hogy átfogó képet nyújtson a gyülöletbűncselekményekkel kapcsolatos hazai tapasztalatokról elsősorban a közösség tagja elleni erőszak tényállása kapcsán, a jogalkotás, a jogalkalmazás, a hivatalos adatgyüjtési rendszer és a jó gyakorlatok szempontjából. Illetve figyelembe véve a társadalom, a civil szervezetek és az állam részéröl létező különféle megoldásokat, megoldási javaslatokkal szolgál a fenti kérdésekben a gyülölet-büncselekmények hatékonyabb megelőzése és kezelése érdekében.

\section{A vizsgált országok kiválasztása során irányadó szempontok}

Az államok kiválasztásánál két főszempontot vettem figyelembe: elsődleges célom az volt, hogy bizonyos szempontból összehasonlítható, más szempontból eltérő helyzetben lévő országokat vizsgáljak. A dolgozat jelen fejezete az összehasonlító büntetőjog egyik 
legalapvetőbb módszerére, a funkcionalista módszertanra ${ }^{9}$ támaszkodik. A gyülöletvezérelte büncselekmények szabályozását tekintve eltérő modellek terjedtek el, amelyeket a büntető-jogtudományban ismert fogalmak szerint két fő csoportra, valamint négy alcsoportra bontottam. Ezen fogalmak használata lehetővé teszi a különböző jogrendszerek gyülölet-büncselekményekkel kapcsolatos szabályainak összehasonlítását. A funkcionalizmus módszere megköveteli, hogy a jogösszehasonlítás során ne önmagukban a vizsgált jelenségekre fókuszáljunk, hanem hogy ezeket a jelenségeket mindig egy nagyobb egység kontextusába beágyazva alapvetően céljuk vagy feladatuk irányából közelítsük meg. ${ }^{10}$ A dolgozat jelen fejezetében éppen ezért a fenti büntetö-jogtudományi fogalmakat veszi alapul és nem csak magára a jelenségre fókuszál, hanem arra, hogy a jelenséget szabályozó rendelkezések milyen formában hatnak a büntetőjogi felelősségre és a jogkövetkezményekre. A vizsgálatot pedig megkönnyíti, hogy a büntetőjog ezen szabályai nem csupán céljukban, de struktúrájukban és formájukban is igen hasonlóak.

Alapvetően a magyar szabályozás elemzése, kritikai értékelése áll érdeklődésem középpontjában, így igyekeztem olyan országokat választani, amelyek például szolgálhatnak. Kézenfekvő megoldás lett volna a környező országokat választani, azonban ezek - Magyarországhoz hasonlóan - nem rendelkeznek jelentős múltú szabályozással és jogalkalmazási tapasztalattal e területen.

Végül igyekeztem úgy kiválasztani az országokat, hogy a szabályozás és joggyakorlat tekintetében az eltérő megoldásokra is felhívhassam a figyelmet.

\section{Ami a dolgozatból kimaradt}

A gyülöletvezérelte büncselekményekhez szorosan kapcsolódnak más, hasonló tartalmú jelenségek és büncselekmények, amelyeket már a dolgozat első fejezetében kizárok a vizsgálat köréből. Másrészt ezek kétségtelenül egymástól nehezen elválasztható kategóriák, így elkerülhetetlen, hogy egyes fejezetekben legalább említés szintjén megjelenjenek.

\footnotetext{
${ }^{9}$ Lásd például: Ralf Michaels: „The Functional Method of Comparative Law” in Mathias ReimannReinhard Zimmermann (szerk.): The Oxford Handbook of Comparative Law, Oxford: Oxford University Press, 2006. 339-382.

10 Lásd Fekete Balázs: A modern jogösszehasonlítás paradigmái. Kísérlet a jogösszehasonlítás történetének új értelmezésére. Budapest: Gondolat Kiadó, 2011, 131.
} 
A gyülölet-büncselekményeket első sorban meg kell különböztetni a gyülöletincidensektöl. A nemzetközi útmutatók ${ }^{11}$ gyülöletvezérelte incidensnek tekintenek minden olyan cselekményt, amely ugyan előítélet motiválta, de nem büncselekmény.

Emellett léteznek olyan büncselekmények, amelyek ugyan magukon viselik az gyülöletvezérelte büncselekmények ismertető jegyeit, de egy-egy jellemzőjük megkülönbözteti azokat a dolgozatban tárgyalt gyülölet-büncselekmény fogalomtól. Vannak olyan büncselekmények, amelyek önmagában a gyülölet kifejeződését büntetik, így azokat legfeljebb a gyülölet-büncselekmények speciális típusának tekinthetjük, így nem is képezik a kutatás fókuszát. Ide tartozik például a gyülöletbeszéd (uszítás, izgatás), ${ }^{12}$ tehát azon megnyilvánulások, amelyekkel valaki - általában elöítélettől, vagy gyülölettől vezérelve - a társadalom csoportjairól vagy azok egyes tagjairól (a csoporthoz tartozásukra tekintettel) szóban vagy írásban olyan állításokat közöl, amelyek sértheti a csoport tagjait, és gyülöletet kelthetnek a társadalomban a csoporttal szemben. ${ }^{13}$

A gyülölet-büncselekmények kapcsán szintén sokszor felmerül a népirtás és az apartheid büncselekménye is, de ezek sem képezik jelen dolgozat fókuszát. Ugyan szintén a közösségek védelmét hivatottak szolgálni, de olyan speciális jellemzőkkel bírnak, amelyek jelentős mértékben megkülönböztetik azokat a Btk.-ban szabályozott más büncselekményektől.

\section{A vizsgálat módszere}

Az értekezés megírása során törekedtem a fellelhető magyar szakirodalmat a lehető legteljesebb körben felhasználni, valamint a téma szempontjából vizsgálom és elemezem a Bírósági Határozatokban, a Büntetőjogi Döntvénytárban közzétett vonatkozó eseti döntéseket, valamint civil szervezetek (Háttér Társaság, Társaság a Szabadságjogokért) által mintegy 25 különböző ügyben rendelkezésemre bocsátott, 2010-2012 közötti nyomozások során keletkezett iratokat.

${ }^{11}$ Ld. pl. EBESZ/DIEJH: Hate Crimes in the OSCE Region: Incidents and Responses. Annual Report for 2012. Varsó, 2013. 13. http://tandis.odihr.pl/hcr2012/pdf/Hate_Crime_Report_full_version.pdf (2014. szeptember 20.) ill. Association of Chief Police Officers (ACPO): Hate Crime Operational Guidance. 2014 , http://www.acpo.police.uk/documents/edhr/2014/140509\%20Hate\%20Crime\%20Op\%20Guidance.pdf (2014. szeptember 20.)

${ }^{12}$ A magyar Btk. közösség ellni uszításként szabályozza (Btk. 332. §).

${ }^{13}$ Lásd Halmai Gábor: Kommunikációs jogok. Budapest: Új Mandátum, 2002. 114. 
A nemzetközi szakirodalmat illetően angol nyelvü munkákat használtam fel, tekintettel arra, hogy a kutatásaim egy részét egy éves kanadai doktori ösztöndíjam ideje alatt végeztem az Albertai Egyetemen. A doktori ösztöndíj keretében az elmélet tanulmányozása mellett a gyakorlat részletes vizsgálatára is lehetőségem nyílt a gyülölet-büncselekmények elleni egységnél végzett kutatások, interjúk és a rendőrség Ride-Along programjában ${ }^{14}$ való részvételem útján.

A szabályozástörténeti kérdésekben nagy jelentőséget tulajdonítok a kodifikációs anyagok és a miniszteri indokolások hasznosításának. A jogalkotási kérdésekkel szoros kapcsolatban az Alkotmánybíróság releváns határozatait is figyelembe vettem, egy-egy részkérdés kapcsán pedig részletesebben elemzem az Alkotmánybíróság álláspontját.

A jogösszehasonlításba bevont angol, dán, kanadai és német büntetőjog esetén szintén a szakirodalom, illetve szekunder irodalom széles körét veszem figyelembe. Néhány esetben az adott ország legfelsőbb bíróságának publikált döntéseit is közvetlenül bevontam a vizsgálatba. Emellett Kanada esetében felhasználtam a kutatásom alatt gyülölet-büncselekmény nyomozócsoport tagjával készített interjúkat és a terepmunkán tapasztaltakat. A jogösszehasonlítás az értekezésnek elsősorban nem a tárgya, hanem szándékom szerint - sokkal inkább a módszere. A dolgozatban ugyan igyekeztem az adott ország szabályozásának minél részletesebb és átfogóbb bemutatására, de az elsődleges cél a magyar helyzettel való összehasonlítás a konkrét kérdés továbbgondolása érdekében.

Amint korábban említettem az értekezés fő célkitüzése a gyülölet-büncselekmények mint jelenség és az azzal kapcsolatos szabályozás és joggyakorlat vizsgálata. Ebből eredően a dolgozatnak egyaránt vannak alapjogi és büntetőjogi vonásai. A dolgozat interdiszciplináris jellegét tovább erősítik a széles körben felhasznált kriminálstatisztikai adatok.

Mindemellett az értekezés nagyban támaszkodik a nemzetközi szervezetek és hazai civil szervezetek állásfoglalásaira, útmutatóira és egyéb dokumentumaira. A magyar szabályozás és joggyakorlat esetében pedig széles körben használtam fel azokat a dokumentumokat, statisztikákat, amelyek a Gyülölet-büncselekmények Elleni

\footnotetext{
${ }^{14} \mathrm{Az}$ edmontoni rendőrség délnyugati részlegének két tagját kísértem egy teljes éjszakai müszakban, amelynek során a munkájuk megfigyelése mellett a részleg számos tagjával készítettem interjút. RideAlong programra lásd bővebben http://www.fyrefly.ualberta.ca/Auction2013Item52 (2015. április 29.)
} 
Munkacsoport egyéni szakértő tagjaként - föként közérdekü adatigénylések és a rendvédelmi szervekkel folytatott megbeszélések keretében - jutottak birtokomba. 


\section{Gyülölet-büncselekmények fogalma}

\section{A fogalom, gyülölet v. elöítélet}

A gyülölet-büncselekmények olyan büncselekmények, amelyeket részben vagy egészben egy csoporttal szembeni elöítélet motivál. A szakirodalom illetve a nemzetközi dokumentumok ${ }^{15}$ egy része sokszor használja az „elöítélet-büncselekmény” kifejezést („bias crime”) a gyülölet motiválta büncselekmény (,hate crime”) helyett, mivel egy társadalmi csoporttal szemben érzett elöítélet a büncselekmény mozgatórugója. Egyes nézetek szerint valamilyen szintű ellenséges érzülettel mindig rendelkezik az elkövető, viszont nem szükséges, hogy az érzelmi állapota elérje a gyülölet szintjét. ${ }^{16}$ Más nézetek szerint elegendő, hogy a büncselekmény mozgatórugója az elöítélet, amely nem feltétlenül az elkövető által érzet elöítéletben nyilvánul meg, hanem a társadalomban meglévő elöítéletekre alapoz. Így például az elkövető azért választ rablás célpontjának meleg áldozatot, aki szexuális orientációját titkolja, mert feltételezi, hogy az áldozat nem mer majd feljelentést tenni, mert akkor bizonyos körülmények - mondjuk, ha a büncselekmény helyszíne egy melegbár volt leleplezhetnék. Tehát elkövető a társadalomban élő előítéletekre, illetve azok hatására alapozza a stratégiáját, és ebben az esetben indifferens, hogy ő maga elöítéletes-e.

Ez a fajta megkülönböztetés az alapja a prototipikus és opportunista gyülöletvezérelte büncselekmények ('prototypical/opportunistic hate crime') elkülönítésének: ${ }^{17} \mathrm{a}$ prototipikus gyülölet-büncselekmény során az elkövetőt a csoport iránti ellenséges érzések motiválják, míg opportunista gyülölet-büncselekmény esetében a társadalomban meglévő elöítéletek jelentik a motiváció bázisát. Ha egy elkövető például, hogy férfiasságát bizonyítsa barátai előtt, egy amish vallású férfit inzultál, mert úgy gondolja, hogy az kiszemelt áldozat nem fog erőszakosan reagálni a konfliktus során, pacifista vallási meggyőződése miatt.

\footnotetext{
15 Lásd például az Európai Biztonsági és Együttműködési Szervezet (EBESZ/OSCE - Organization for Security and Co-operation in Europe) 2009. december 2-án elfogadott 9/09. számú Miniszter Tanácsi határozatát.

${ }^{16}$ Balogh Lídia-Pap András László: „A homofób és transzfób indíttatású gyülölet-büncselekmények előfordulása, valamint a jogi fellépés keretei Magyarországon” in Takács Judit (szerk.): Homofóbia Magyarországon. Budapest: L’Harmattan, 2011. 129.

17 Jordan Blair Woods: „Taking the »Hate« Out of Hate Crimes: Applying Unfair Advantage Theory to Justify the Enhanced Punishment of Opportunistic Bias Crimes", UCLA Law Review, 2008/2. 491.
} 
A differenciálás egy másik fajtája, a „rasszista indíttatású” ('racial animus') és diszkriminációs szelekción alapuló ('discriminatory selection') gyülöletmotiválta büncselekmények. ${ }^{18}$ Az előbbi kategória esetében az elkövető olyan ellenséges érzelem által motiválva követi el a cselekményt, amelyet az áldozat csoportja, illetve az áldozat iránt érez annak csoporttagsága miatt, akárcsak a prototipikus gyülöletvezérelte büncselekmények esetében. A második esetkörbe pedig azok az esetek tartoznak, amikor az áldozat kiválasztását a társadalomban egy adott csoporttal szemben meglévő elöítéletekre alapozza az elkövető. Azonban a rasszista indíttatású büncselekmények esetében sem arról van szó, hogy az adott ellenérzésnek el kell érnie a gyülölet szintjét; elegendő, ha az elkövető ellenséges érzelmeket táplál az áldozat és csoportja iránt. Ha a gyülöletvezérelte büncselekmények esetében kizárólag a gyülölet általános jelentésére szorítkoznánk - heves ellenszenv, nagyfokú ellenséges indulat, ${ }^{19}$ illetve tartós, agresszív impulzusok -, akkor az elkövetők köre leszükülne a legextrémebb gyülölet-indíttatású cselekményekre. Éppen ezért a gyülölet-büncselekmény kifejezést ebben a tágabb értelemben használom; nem leszükítve a gyülöletre mint szélsőséges érzelemre, inkább szinonimaként az elöítélet-vezérelte büncselekményekre.

A harmadik megkülönböztetés szerint elkülöníthetőek az ún. szimbolikus ('symbolical') és az aktuárius ('actuarial') gyülölet-büncselekmények. ${ }^{20}$ Ezen két elnevezés is kitünően szemlélteti az elkövető motivációjának alapjait. Hiszen, míg a szimbolikus gyülöletbüncselekmények esetén az áldozat egyértelmüen jelképezi az elkövető számára mindazt, amire az ellenérzései irányulnak, addig a második kategória esetében az elkövető társadalmi sztereotípiákra építve követi el a büncselekményt, leginkább annak érdekében, hogy nagyobb és/vagy könnyebb „haszonhoz” jusson. ${ }^{21}$ A két kategória közötti különbség felvázolja a lehetséges határokat a gyülöletvezérelte és egyéb bűncselekmények között. A szimbolikus büncselekmények szinte minden ésszerü megközelítés alapján gyülöletmotiválta cselekményeknek tekinthetők, míg az aktuárius cselekményeket sok esetben érdemes más kategóriába sorolni: ugyanis a gyülöletbűncselekmények fogalma alapjában véve az elkövető motivációjára épül, az aktuárius

\footnotetext{
${ }^{18}$ Frederick M. Lawrence: Punishing Hate: Bias Crimes Under American Law, Cambridge, Ma: Harvard University Press, 1999, 30.

${ }^{19}$ Magyar Értelmező Kéziszótár, Budapest: Akadémia Kiadó, 1992. 491.

20 Sara Steen-Mark A. Cohen: “Assessing the Public's Demand for Hate Crime Penalties”, Justice Quarterly, 2004/1.94.

${ }^{21}$ Például: egy zsebtolvaj csupán nőktől lop, mert úgy gondolja, hogy női táskából könnyebb kivenni egy pénztárcát, mint egy férfi nadrágzsebéből.
} 
cselekmények esetén viszont az elkövetők a társadalmi elöítéleteket nem szimbolikus cél eléréséhez „használják”. Természetesen a gyakorlatban közel sem ilyen egyszerü különbséget tenni a kategóriák között;22 illetve szinte lehetetlen olyan definíciót alkotni, amely teljes egészében lefedné a gyülölet-büncselekmények összes típusát. A fogalom függ a társadalmi és történelmi kontextustól, a jelenség pedig kontextusonként is dinamikusan változónak tekinthető. ${ }^{23}$

A gyülület-büncselekmény megvalósulásához két együttes feltétel fennállására van szükség: egy „alapbüncselekmény” megvalósulására (amely lehet személy vagy dolog elleni erőszak is, így pl. emberölés, testi sértés, rongálás, garázdaság), másrészt az ezen cselekményt motiváló előítéletre. Ezáltal a gyülölet-büncselekmény inkább a motiváció, és nem a tett által meghatározott cselekmény.

A gyülölet-büncselekmény áldozatait az elkövető az áldozat egy vagy több vélt vagy valós tulajdonsága - például vallása, etnikai hovatartozása, szexuális orientációja, fogyatékossága - alapján választja ki. Így nem szükséges, hogy az áldozat valóban az adott csoporthoz tartozzék, akkor is megilleti a védelem, ha valójában nem is tartozik az adott csoporthoz, csupán az elkövető percepciója alapján sorolódott a csoporthoz. Így például Németországban a 16 éves Marinus Schoberl gyilkosság áldozatává vált vélt zsidó származása miatt. Csehországban egy török férfi vált szkinhedtámadás áldozatává vélt roma származása miatt. ${ }^{24}$ Ugyancsak gyülölet-büncselekménynek tekinthető a dolog elleni erőszak, amikor a büncselekményt a védett csoportokhoz vagy ilyen csoportok tagjához tartozó vagy ezekkel azonosított vagyontárgyak, ingatlanok, azaz a társadalmi csoporttal összefüggésbe hozható dolog sérelmére követik el.

A gyülöletvezérelte büncselekmények fogalmának kialakítását az indokolja, hogy az emberek egyes tulajdonságai - például a bőrszín, a vallás, a szexuális orientáció - a személyiség olyan lényeges elemének tekinthetőek, amelyek a kiemelt, speciális védelem igényét is hordozzák. Ezek az úgynevezett védett tulajdonságok, amelyek alapján az egyébként összehasonlítható helyzetben lévő személyek között tilos különbséget tenni - néhány kivételtől eltekintve, amikor a különbségtétel kifejezetten

${ }^{22}$ Richard A. Berk-Elizabeth A. Boyd-Karl M. Hamner: ,Thinking More Clearly About Hate-Motivated Crimes" in Barbara Perry (szerk.): Hate and Bias Crime, A Reader. New York: Routledge, 2003, 52.

${ }^{23}$ Ld. Barbara Perry (szerk.): Hate and Bias Crime, A Reader, New York: Routledge, 2003, 4. (Introduction).

${ }^{24}$ Lásd.: OSCE - Office for Democratic Institutions and Human Rights (ODIHR/DIEJH): Hate Crime Laws. A Practical Guide. 2009, 50. http://www.osce.org/odihr/36426 (2013. december 3.) 
megjelölt társadalmi csoport tárgyilagos értékelésen alapuló esélyegyenlőtlenségének felszámolására irányul. Az, hogy mi számít a védett tulajdonságnak, térben és időben, társadalmi és politikai körülmények függvényében változhat. ${ }^{25}$

Álláspontom szerint az egyik legkomplexebb fogalmat az Európai Biztonsági és Együttmüködési Szervezet (továbbiakban: EBESZ) ${ }^{26}$ Miniszteri Tanácsának a gyülöletbűncselekmények elleni küzdelemről szóló határozatában ${ }^{27}$ találhatjuk, mely szerint elöítéletes büncselekmény:

\begin{abstract}
„A) minden olyan büncselekmény, ideértve a személy vagy vagyon elleni büncselekményeket, ahol a büncselekmény áldozatának, helyszínének vagy tárgyának kiválasztása mögött ezen áldozatok, helyszínek vagy tárgyak B pontban meghatározott csoporthoz való vélt vagy valós tartozása, e csoporthoz füzödö kapcsolata, vagy e csoport számára nyújtott támogatása áll;
\end{abstract}

B) egy csoport bármely olyan tulajdonságon alapulhat, amelyben a csoport tagjai osztoznak, így például a tagok vélt vagy valós faji hovatartozása, nemzeti vagy etnikai származása, nyelve, börszíne, vallása, neme, kora, értelmi vagy testi fogyatékossága, szexuális irányultsága vagy más hasonló tulajdonsága. "28

\title{
2. Elhatárolás más előítélet vezérelte cselekményektől
}

\section{A) Gyülölet-incidens}

\footnotetext{
${ }^{25}$ Ezek többnyire olyan tulajdonságokhoz kötődnek, amelyeket illetően az egyénnek nincs döntése. Ettől függetlenül a védelem jogosultsága nem kérdőjeleződik meg például a vallási hovatartozás esetén sem, noha az érintettek dönthetnének úgy is, hogy más vallás követőivé válnak - ez azonban olyan „magas költséggel" (a személyiségük lényegéhez tartozó meggyőződésük, az identitásuk feladásával) járna, amelynek viselése nem várható el az egyéntől. Ugyanígy, a bőrszín alapú diszkrimináció attól még nem válna megengedetté, ha egy biotechnológiai eljárásnak köszönhetően valamennyi fekete bőrpigmentációja megváltoztathatóvá válna. Ld. Balogh - Pap, i.m. 129. ill. Pap András László: „Overruling Murphy’s law on the free choice of identity and the racial-ethnic-national terminology-triad: Notes on how the legal and political conceptualization of minority communities and membership boundaries is induced by the groups' claims" in Kristin Henrard (szerk.): The interrelation between the right to identity of Minorities and their Socio-economic Participation, Leiden - Boston: Brill, 2013. 115-155.

${ }^{26}$ Organization for Security and Co-operation in Europe, OSCE. http://www.osce.org

${ }^{27}$ EBESZ 9/09. számú Miniszter Tanácsi határozat.

28 A fogalom fordítását ld.: Dombos Tamás „Gyülölet-büncselekmények Magyarországon: Jogi szabályozás, statisztikai adatok, sértetti csoportok" c. előadása, elhangzott: Magyar Tudományos Akadémia IX. Osztály Állam- és Jogtudományi Bizottság Rendészeti Albizottsága, 2013. március 8. A gyülölet-büncselekmények - dogmatika és joggyakorlat címü tudományos ülés; ill. ld. Dinók Henriett: „A gyülölet-büncselekmények: dogmatika és joggyakorlat” Belügyi Szemle, 2013/12. 52-67.
} 
A gyülölet-büncselekményeket meg kell különböztetni a gyülölet-incidensektől. A nemzetközi útmutatók ${ }^{29}$ gyülöletvezérelte incidensnek tekintenek minden olyan incidens, cselekményt, amely ugyan elöítélet motiválta, de nem büncselekmény. Nem büncselekmény azért például, mert a cselekmény nem büncselekmény a hatályos jogszabályok.

\section{B) Gyülöletbeszéd}

Léteznek olyan büncselekmények, amelyek ugyan magukon viselik az elöítéletvezérelte büncselekmények ismertető jegyeit, de egy-egy jellemzőjük megkülönbözteti azokat a dolgozatban tárgyalt gyülölet-büncselekmény fogalomtól. Vannak olyan büncselekmények, amelyek önmagában a gyülölet kifejeződését büntetik, így azokat legfeljebb a gyülölet-büncselekmények speciális típusának tekinthetjük, így nem is képezik a kutatás fókuszát. Ide tartozik például a gyülöletbeszéd (uszítás, izgatás), ${ }^{30}$ tehát azon megnyilvánulások, amelyekkel valaki - általában elöítélettől, vagy gyülölettől vezérelve - a társadalom csoportjairól vagy azok egyes tagjairól (a csoporthoz tartozásukra tekintettel) szóban vagy írásban olyan állításokat közöl, amelyek sértheti a csoport tagjait, és gyülöletet kelthetnek a társadalomban a csoporttal szemben. ${ }^{31}$ Noha a legtöbb jogrendszerekben, így a magyarban is a gyülöletbeszéd büncselekménynek számítanak, azonban ezek esetében hiányzik a gyülöletbüncselekmény fogalmának egyik lényegi eleme, az alapbüncselekmény (például testi sértés, garázdaság, rongálás stb.). Ehelyett a gyülölet kinyilatkoztatásának formáját rendelik büntetni. ${ }^{32}$

C) Népirtás és apartheid büncselekménye

A fogalomnak a népirtás és az apartheid büncselekménye is megfelel, de ezek sem képezik jelen dolgozat fókuszát. Ugyan szintén a közösségek védelmét hivatottak

\footnotetext{
${ }^{29}$ Ld. pl. EBESZ/DIEJH: Hate Crimes in the OSCE Region: Incidents and Responses. Annual Report for 2012. Varsó, 2013. 13. http://tandis.odihr.pl/hcr2012/pdf/Hate_Crime_Report_full_version.pdf (2014. szeptember 20.) ill. Association of Chief Police Officers (ACPO): Hate Crime Operational Guidance. 2014 ,

http://www.acpo.police.uk/documents/edhr/2014/140509\%20Hate\%20Crime\%20Op\%20Guidance.pdf (2014. szeptember 20.)

${ }^{30}$ A magyar Btk. közösség ellni uszításként szabályozza (Btk. 332. §).

${ }^{31}$ Halmai Gábor fogalom meghatározása alapján. Ld. Halmai Gábor: Kommunikációs jogok. Budapest: Új Mandátum, 2002. 114.

32 Gyülöletbeszédre lásd bővebben Koltay András (szerk.): A gyülöletbeszéd korlátozása Magyarországon, Budapest: CompLex Kiadó, 2013.
} 
szolgálni, de olyan speciális jellemzőkkel bírnak, amelyek jelentős mértékben megkülönböztetik azokat a Btk.-ban szabályozott más büncselekményektől. Ezen cselekmények az adott csoport teljes vagy részleges megsemmisítésére, elnyomására irányulnak, volumenükben teljesen eltérnek más büncselekményektől. A magyar szabályozásban az emberiesség elleni büncselekmények között szerepelnek, jogi tárgyuk az emberiség legalapvetőbb morális értékei, adott esetben az emberiség békéje és biztonsága. ${ }^{33}$ Mindebből kifolyólag pedig egészen más jogalkotási és eljárásjogi szempontok érvényesülnek e cselekményekre vonatkozóan, mint például a közösség tagja elleni erőszakra.

\section{Az egyénre, közösségre és társadalomra gyakorolt hatás}

Számos szempont létezik, amelyek alapján gyülöletvezérelte büncselekmények megkülönböztetőek más büncselekményektől. A gyülölet-büncselekmények hatásai három különböző szinten ragadhatók meg: az egyén, azaz a sértett; a közösség, azaz a védett csoport; valamint a társadalom szintjén.

\subsection{Gyülölet-büncselekmények az egyéni áldozat szintjén}

Az egyénre gyakorolt hatások tekintetében a kutatások azt mutatják, hogy az áldozatra gyakorolt pszichikai hatás súlyosabb, mint más bűncselekmények esetében. ${ }^{34}$ A British Crime Survey ${ }^{35}$ eredményei szerint a rasszista motivációból elkövetett büncselekmények áldozatainál magas szintü érzelmi reakciók figyelhetők meg a büncselekményt követően, így többek között félelemérzet, sokk, depresszió, illetve alvási nehézségek. ${ }^{36} \mathrm{~A}$ gyülöletvezérelte büncselekmények áldozatainak nagyobb része számolt be - összehasonlítva a nem rasszista büncselekmények áldozataival - arról, hogy aggódik, illetve nagyon aggódik amiatt, hogy ismét áldozattá válhat. Az egyetlen

${ }^{33}$ Lásd Görgényi Ilona [et al.]: Magyar Büntetőjog - Különös rész. Budapest: Complex Kiadó, 2013. XIII. fejezet, Az emberiesség elleni büncselekmények.

${ }^{34}$ Lásd pl. Paul Iganski-Sporidoula Lagou: "How Hate Crimes Hurt More: Evidence from the British Crime Survey" in Barbara Perry and Paul Iganski (szerk.): Hate Crimes: The Consequences of Hate Crime, Vol 2. Westport: Praeger, 2009. 1-13. ill. Jack McDevitt [et al.]: „Consequences for Victims. A Comparison of Bias- and Non-Bias-Motivated Assaults" American Behavioral Scientist, 2001/4. 139151.

351982 óta folytatott, bünözéssel kapcsolatos felmérés, amely Angliára és Walesre terjed ki, és amelynek során arról kérdezik a lakosság tagjait, hogy az elmúlt egy évben büncselekmény áldozataivá váltak-e; az egyes bűncselekménytípusok elterjedtségének és természetének vizsgálata érdekében. 2012 és 2013-as év során 50.000 háztartás vett részt a felmérésben, amely a fel nem jelentett esetekre is kiterjed. Ld. http://www.crimesurvey.co.uk

36 EBESZ/DIEJH: Prosecuting Hate Crimes: A Practical Guide. 2014. http://www.osce.org/odihr/prosecutorsguide?download=true 
kivételt ez alól a szexuális erőszak áldozatai jelentették, akik a rasszista erőszak áldozataival azonos arányban tartottak az ellenük elkövetett büncselekmény megismétlődésének veszélyétől. ${ }^{37}$

Iganski és Lagou tanulmányukban a British Crime Survey 2002-2005-es adatait vizsgálták. Az említett időszakban angol és walesi háztartások 16 év feletti tagjait kérdezték arról, hogy a felmérést megelőző tizenkét hónapon belül büncselekmény áldozataivá váltak-e ő maguk vagy a velük egy háztartásban élők, és ha igen, akkor hány alkalommal. A felmérés során, sajnos, csak a rasszista motivációra kérdeztek rá a gyülölet vezérelte büncselekmények körében, egyéb (például antiszemita vagy homofób) motivációra nem. A gyülölet-büncselekmények áldozatainak többsége egyszeri incidenst jelentett, de jó néhány esetben ismétlődő viktimizációról volt szó. A felmérés módszertanát illetően megjegyzendő, hogy ha tizenkét hónapon belül több mint hat különböző incidens történt a válaszadóval, akkor csak az első hat jelent meg az eredmények között; illetve, ha egy bizonyos büncselekmény többször fordult elö, akkor sorozatos cselekményként tüntették fel.

A felmérés kitért arra is, hogy milyen változásokat eredményezett a családok életében a bűncselekmény megtörténte, különösen a védelmi intézkedések terén. ${ }^{38} \mathrm{~A}$ kutatási eredményekből kiderül, hogy a súlyosabb következmények különösen a pszichés, érzelmi hatások terén jelentkeztek. Vegyünk például egy családot, amely folyamatosan rasszista zaklatásoknak van kitéve: a zaklatások eredményeként a család mentális és pszichikai egészsége egyaránt sérülhet; illetve, a gyerekek mentális, fizikai egészsége és szocializációja egyaránt veszélyeztetett, mert a szülők nem merik elengedni őket otthonról játszani, alulteljesítenek az iskolában az otthoni stressz hatására, szélsőséges esetben a szülök a félelem hatására teljesen bezárkóznak, és még iskolába sem engedik a gyerekeket. Az ilyen családoknak közösségi támogatásra is szüksége van - a lakóközösségtől, a rendőröktől, az iskolai személyzettől és egyéb intézményektől - a félelem feloldása érdekében. ${ }^{39}$ Kitünő példa a közösségi kezdeményezésekre a gyülöletbüncselekmények megelőzése terén a „Not In Our Town” elnevezésű kezdeményezés, amely az amerikai egyesült államokbeli Billingsböl (Montana) indult, egy olyan eset kapcsán, amikor szkinhedek megfélemlítettek egy afroamerikaikból álló vallási

\footnotetext{
${ }^{37}$ Iganski - Lagou 2009, 9.

${ }^{38}$ Iganski-Lagou 2009, 3.

${ }^{39}$ Iganski-Lagou 2009, 6.
} 
közösséget: a billingsi lakosok közösen kezdték őrizni a gyülekezet tagjait. Később, mikor egy őslakos család házának falára fújtak rasszista graffitit, a városbeliek újrafestették a házat, majd amikor egy hatéves zsidó gyermek szobájának ablakát kővel dobták be,tízezer ember helyezett el menórát ${ }^{40}$ az ablakában, hogy így tiltakozzanak a tett ellen, és így biztosítsák a megtámadott családot a támogatásukról. A kezdeményezés - amely mára már mozgalommá nőtte ki magát Észak-Amerikában - célja, hogy a helyi közösségek tagjainak bevonásával felderítsen minden gyülöleten alapuló tevékenységet, biztosítsa az áldozatokat a közösség támogatásáról, valamint például közösségi akcióterveket alakítson ki, szem elött tartva a közösségek sokszínűségét mint kiemelt értéket. ${ }^{41}$

Az egyénre és családra gyakorolt hatások kapcsán érdemes megemlíteni, hogy a mindennapi diskurzusban sokszor felmerülő érv a gyülölet-büncselekményeknek kapcsán, hogy elkövetésüket gyakran különös kegyetlenség jellemzi. Valójában inkább az jellemző, hogy a kegyetlenebb esetek kapnak nagyobb figyelmet éppen e jellegükből kifolyólag, míg a nagyobb számban megjelenő például rongálási, garázdasági esetek kevésbé. Azonban pont ezek a kisebb súlyú cselekmények, amelyek legtöbbször befolyásolhatják az áldozat és a család mindennapjait.

Herek, Gillis és Cogan ${ }^{42}$ összehasonlító kutatásokat végeztek, amelynek keretében meleg férfiakat és leszbikus nöket kérdeztek arról, hogy követtek-e el ellenük homofób büncselekményeket az utóbbi öt évben. A kutatás eredményeként megállapították, hogy az áldozatoknál sokkal nagyobb arányban jelent meg depresszió, düh és poszttraumás stressz-zavar.

A legátfogóbb kutatást a pszichológiai hatások tekintetében McDevitt, Balboni, Garcia és $\mathrm{Gu}^{43}$ készítették, 1991 és 1997 közötti bostoni eseteket vizsgálva. A kutatásban gyülölet-büncselekmények és más büncselekmények áldozatai egyaránt részt vettek. A kérdőívek kifejezetten a pszichológiai hatások mérésére készültek. A tizenkilencből hat tétel szignifikáns eltérést mutatott a gyülölet-büncselekmények és párhuzamos

\footnotetext{
${ }^{40}$ Hétágú gyertyatartó; zsidó vallási szimbólum.

${ }_{41}$ Bővebben ld. http://www.niotbillings.org/; vagy About Not In Our Town http://www.youtube.com/watch?v=1Q4fLMZnFfA (2013. december 2.); vagy https://www.niot.org/front (2015. január 12.)

${ }^{42}$ Herek [et al]: Victim Experiences in Hate Crimes Based on Sexual Orientation, Journal of Social Issues, 2002/2. 243-259.

${ }^{43}$ Lásd Jack McDevitt [et al.] 2001, 139-151.
} 
büncselekmények áldozatai között (depresszió, idegesség, koncentrációs problémák, az esetről való önkéntelen gondolkodás, jelentéktelenségérzet stb.).

\subsection{Gyülölet-büncselekmények második szintje, a védett csoport. Gyülölet-} büncselekmények, mint üzenet-büncselekmények

Az egyénre gyakorolt hatások mellett a gyülölet-büncselekmények sajátossága, hogy nem csupán az individuum ellen irányul a támadás, hanem a közösség valamennyi tagja veszélyeztetve érezheti magát. Hasonló a megközelítés a szexuális erőszak esetében is (ha egy nő szexuális erőszak áldozatává válik, a többi nőben is a felmerülhet, hogy akár ő is lehetett volna az áldozat). ${ }^{44}$ Az egyéni és közösségi hatásokhoz is egyaránt köthető, sokszor emlegetett jellemzője a gyülölet-büncselekményeknek, hogy „üzenetbüncselekmény”-eknek tarthatóak, ${ }^{45}$ mert az áldozatok nem egyénként válnak célponttá, hanem mint szimbólumok, a közösség megtestesítői - így a büncselekmény egy üzenetnek tekinthető a teljes közösség felé. Emiatt a gyülölet-büncselekmények velejárója a félelem átvetülése a csoportra. Weinstein ${ }^{46}$ in terrorem-hatásnak nevezi ezt a jelenséget, amikor egy csoport megfélemlítése egy vagy több tag viktimizációján keresztül történik.

Mivel áldozat - feltételezett hovatartozása miatt - szimbolikus jelentőséggel bír a tettes számára, ezért az áldozattal nem mint személlyel foglalkozik, hanem annak személyiségét néhány valós vagy vélt tulajdonságára redukálja. ${ }^{47}$ Ezt a megközelítést támasztja alá egy 2012-es magyar homofób gyülölet-büncselekmény, amely különös kegyetlensége ellenére csak szük körben vált ismertté. Az ítéletben foglalt tényállás szerint: az elkövető

“[a] büncselekmény elkövetését megelözően kb. egy évvel korábban olvasott újságban, illetve a teletexten sok olyan hirdetést, amelyben férfi keresett férfi partnert magának, ezért ez a gyülölet erösödött benne olyan szinten, hogy szeretett volna többet is »kinyírni«,

\footnotetext{
${ }^{44}$ Iganski-Lagou 2009, 2.

45 Lásd pl. Barbara Perry: In the Name of Hate. Understanding Hate Crimes. New York - London: Routledge 2001. ill. Barbara Perry-Shahid Alvi: 'We are vulnerable': The in terrorem effects of hate crimes, International Review of Victomology, 2011/18. 57-71. ill. Danka Anita: „Rossz helyen lenni rossz időben, avagy mit üzennek a gyülölet-büncselekmények?”, Föld-rész, 2009 /3-4. 92-96.

46 James Weinstein: „First Amendment challenges to hate crime legislation: Where's the speech?” Criminal Justice Ethics, 1993/ 2. 12-13.

${ }^{47}$ Utasi Judit: „A gyülöletbünözés háttere”, Kriminológiai Tanulmányok, 48. kötet, 2011. 115-126.
} 
méghozzá úgy, hogy fegyvert vesz magának. Végül is erröl letett, mert nem volt pénze fegyverre, nem is tudta, hogy hogyan szerezzen. Ezek után a vádlott úgy döntött, hogy nem egyszerre többet, hanem csak egyszerre egyet próbál megölni, azért, hogy fogyjanak. (...) A vádlott (...) felkelt, és reggeli után eszébe jutott homoszexuális személyekkel szemben érzett gyülölete. Majd eltervezte, »a mai nap tökéletes hogy egyet végre megöl belölük«. Bekapcsolta a televíziót ahol a ... Teletext ... oldalán véletlenül rátalált a sértett a $06 / . .$. -as telefonszámára. A vádlottban tudatosult, hogy ö lesz a mai »áldozata«. Azt is eltervezte, hogy hogyan fogja megölni. ',48

Ahogy az eset is mutatja az elkövető véletlenszerüen választotta ki áldozatát annak csoporttagsága alapján, az áldozatra nem mint egyénre, hanem a csoport megtestesítőjére tekintett.

Az egy-egy társadalmi csoporttal szembeni előítélet nemcsak motivációt jelenthet, de az elkövetők számára igazolásul is szolgálhat a tettre. A kiválasztott áldozatok az elkövetők szemében egymással „helyettesíthetők” (és ebben is gyökereznek a közösséget is érintő hatások); az ilyen büncselekmények jelentős részét az áldozatok számára ismeretlenek követik el, és az áldozatok sokszor éreznek frusztrációt amiatt, hogy nem tehetnek semmit egy újabb büncselekmény elkerülése érdekében, hiszen csak „rossz helyen voltak rossz időben”. 49

Helen $\mathrm{Ah} \mathrm{Lim}^{50}$ a gyülölet-büncselekmények hatásai körében abból indul ki, hogy a gyülölet-büncselekmények esetében a felsőbbrendüség érzete vezérli az elkövetőt, az erőszakot és egyenlőtlenséget egyfajta „mi és ők” gondolkodásmóddal igazolja. Az elkövetők úgy gondolják, hogy kívülállók ellen harcolnak, akik nem osztják az értékeiket, akik a szabadságukat és a jogaikat fenyegetik. Ezért úgy érzik, hogy üzenetet kell küldeniük a teljes csoport felé. A szerző 2002-2003 során mélyinterjúkat készített negyvenöt ázsiai-amerikai személlyel: a válaszadók értelmezésében a gyülöletbűncselekmények kívülállók elleni büncselekményekként jelentek meg, amelyek azt közvetítik, hogy a megcélzottak „mások”, „nem egyenlők”. A gyülölet vezérelte

\footnotetext{
${ }^{48}$ A Háttér Társaság által kutatási célból átadott ügyek. Debreceni Törvényszék, 25.B.48/2013/23. sz.

${ }^{49}$ Danka 2009, 95.

${ }^{50}$ Helen Ahm Lim: "Beyond the Immediate Victim: Understanding Hate Crimes as Message Crimes", in Barbara Perry and Paul Iganski (szerk.): Hate Crimes: The Consequences of Hate Crime, Vol 2, Westport: Praeger, 2009. 107-122.
} 
büncselekmény a csoporthoz tartozás miatt célozza az áldozatát; illetve egy olyan csoporthovatartozás miatt, amely az elkövető percepcióján alapszik. ${ }^{51}$

A gyülölet-büncselekmények esetében az első két dimenzió, az egyénre valamint a közösségre gyakorolt hatások közül többnyire csak az első - az áldozatra gyakorolt pszichikai hatás - kap figyelmet, és az sem a szükséges mértékben. Hogy megértsük a kollektív és kumulatív hatásait a cselekménynek; azt, hogy hogyan hat az erőszak az etnikai, vallási és egyéb védett tulajdonságok alapján meghatározott társadalmi csoportok közötti kapcsolatokra, az első lépés, hogy képet kapjunk a viktimizáció hatásairól a közvetlen érintettek tekintetében. Nem véletlenül hangzik el sokszor az az értelmezés, amelyet az egyéni beszámolók is megerösítenek, hogy a gyülöletbüncselekmények üzenet-büncselekmények, ${ }^{52}$ amelyek jelzésértéküek az érintett csoport számára; azt üzenik a csoport közvetlenül nem érintett tagjainak, hogy „,te is ott feküdhettél volna a földön, megalázva, vérbe fagyva”.

\subsection{A gyülölet-büncselekmények hatásainak harmadik dimenziója, a társadalmi hatások}

$\mathrm{Az}$ első két dimenzióval párhuzamosan jelenik meg a gyülöletvezérlte büncselekmények hatásainak harmadik területe, a társadalmi hatások. Az elöítéletvezérelte büncselekményekkel kapcsolatos tapasztalatok azt mutatják, hogy az aggodalom és a félelem adott esetben kiválthatja a megtámadott csoportban a megtorlás iránti vágyat, végső soron társadalmi csoportok közötti feszültséghez, agresszióhoz vagy akár összecsapásokhoz vezethet.

Az Egyesült Államokban a Wisconsin kontra Mitchell (1993) ügyben ${ }^{53}$ Rehnquist fóbíró rámutatott arra, hogy a gyülölet-büncselekményeknek szentelt kiemelt figyelem azért is fontos, mert az ilyen büncselekmények további erőszakhoz vezethetnek. A nevezett ügy rövid tényállása szerint: 1989. október 7-én éjjel fiatal fekete férfiak és fiúk egy lakásban gyültek össze Kenoshaban (Wisconsin), és a Lángoló Mississippi címü film egy megrázó jelenetéről társalogtak, amelyben egy fehér férfi egy fekete fiút ütlegel imádkozás közben. Végül a beszélgetés hatására az utcára mentek, és megtámadták az első feléjük sétáló fehér fiút. Ezt a hatást illusztrálják az alábbi példák is: 1989-ban New

\footnotetext{
${ }^{51} \operatorname{Lim} 2009,107$.

${ }^{52}$ Lásd Lim 2009, ill. pl. James B. Jacobs: "The Emergence and Implications of American Hate Crime Jurisprudence”, In. Barbara Perry (ed.): Hate and Bias Crime, A Reader, New York: Routledge, 2003. 409-426.

${ }^{53}$ Bővebben lásd: http://www.law.cornell.edu/supct/html/92-515.ZO.html (2013. december 7.)
} 
York városában egy fiatal afroamerikai meggyilkolását követően faji összetüzésekre került sor; Carson Cityben (Nevada) pedig 2002-ben tizenkét őslakos férfi támadott meg két hispán férfit, mert úgy vélték, hogy részük volt egy korábbi támadásban, amely őslakos ellen irányult. Ez a két eset kifejezetten arra példa, amikor a megtorlási vágy eluralkodik a megtámadott csoportok tagjain és végül egy másik csoporttal szembeni erőszakban csúcsosodik ki.

Egyes nézetek szerint az ilyen jellegű megtorló motiváció is a gyülöletbüncselekmények körébe vonható; egy kutatás például kimutatta, hogy a feljelentett ügyek egy része korábbi támadásokra adott válasz volt. ${ }^{54}$ Ha a megtámadott csoport nem is fordul közvetlenül az elkövető csoportja ellen, a gyülölet vezérelte büncselekmények akkor is egyértelmüen ártalmasak a közösségek közötti kapcsolatokra nézve.

A közelmúltból pedig egy igen komplex példa Michael Brown esete mutatja, hogy a gyülölet-büncselekmény gyanúja is kiválthat társadalmon belüli feszültségeket. Michael Brownt, 18 éves, fegyvertelen, afroamerikai fiút 2014. augusztus 9-én, Ferguson városában (Missouri) Darren Wilson, fehér rendőr intézkedés közben - vitatott körülmények között - lött le, a fiú belehalt a sérülésekbe. Az esetet hatalmas köz- és média érdeklődés kísérte. Az eset kapcsán indult eljárásban úgy döntöttek, hogy nem emelnek vádat Wilson rendőrrel szemben. A Fergusonban megindult demonstráció sorozatban a javarészt afroamerikai tüntetők álltak szemben a többnyire fehér rendőrökkel (53 fös állomány, 4 fő afroamerikai). Az eset országos szinten társadalmi csoportok közötti feszültségeket is eredményezett. ${ }^{55}$

Az irodalom és a filmmüvészet bőséges és szemléletes példával szolgálhat mind társadalmi, mind jogi kérdésekre. A társadalmi csoportok közötti konfliktusok és a gyülölet, illetve a bosszú motívumának megjelenítésére remek példákat találhatunk Quentin Tarantino munkáiban: a Becstelen brigantyk (2009) címü filmjében például a második világháború idején amerikai zsidók egy csoportja náci katonákat kínoz meg és végez ki könyörtelenül. A zsidó csoport tagjai ügynökként vadásznak a nácikra, akiket megölnek és megskalpolnak a zsidóság elleni tetteik megtorlásaként. Az erőszak

${ }^{54}$ Perry - Olsson 2009, 179.

55 Bővebben lásd pl. What happened in Ferguson? New York Times, 2014. november. http://www.nytimes.com/interactive/2014/08/13/us/ferguson-missouri-town-under-siege-after-policeshooting.html?_r=0 (2015. január 14.) 
ilyesfajta fordított megjelenítése egyébként nem jellemző az ismertebb holokausztfilmekben: ugyanis azt a helyzetet láthatjuk, amikor a megtámadott csoport tagjai a megfélemlítés, erőszak és kegyetlenség hatására kialakult bosszúvágytól vezérelve elkövetőkké válnak, és áldozataikon a csoporthoz tartozásuk alapján, válogatás nélkül állnak bosszút. Megjegyzem, hogy mindezt úgy jeleníti meg a rendező, hogy a néző szemében a nácik továbbra is megmaradnak kegyetlen elkövetőknek, akikre lehetetlen áldozatként tekinteni. 
Emellett bizonyos szempontból ide sorolom (nem kifejezetten a megtorló erőszak megnyilvánulásaként, hanem az megtámadott csoportra gyakorolt hatások, illetve a társadalmi csoportok közötti konfliktusok példájaként) a romák elleni 2008-2009-es támadássorozathoz $^{56}$ kapcsolódó azon eseteket, amelyek kapcsán a bíróság roma embereket ítélt el közösség tagja elleni eröszak büncselekménye, azaz gyülöletbüncselekmény miatt. ${ }^{57}$ A legismertebb eset 2009 márciusában történt. A Miskolcon olyan hírek terjedtek el, hogy cigányellenes támadások várhatók, a helyi roma közösség ezen félelmét csak tovább erősítette a fokozott rendőri készültség. Többségében romák lakta városrészen a családjaik védelmére készülődő férfiak egy autó utasaira támadtak. Az autó utasai közül - akik nyolc napon belül gyógyuló sérüléseket szenvedtek egynek bizonyítottan szkinhed-kötődése volt. Állításuk szerint azért járták autójukkal hajnali fél kettőkor a föként romák lakta területet, egy több liter gázolajat tartalmazó kannával, mert éjjel-nappali boltot kerestek. A Miskolci Városi Bíróság összesen harmincnégy év szabadságvesztést szabott ki a roma vádlottakra közösség tagja elleni erőszak büncselekménye miatt. A bíróság indokolása szerint a magyarok elleni elöítéletes indítékot két bizonyíték támasztotta alá: egy „halál a magyarokra” feliratú bot, továbbá az egyik vádlott vallomása, aki a támadáskor (egyedüliként) magyarellenes szidalmakat kiabált. Ezt a vallomást - amelyet állítása szerint rendőri kényszerítés hatására tett - a vádlott a bíróságon visszavonta. A 2010 őszén az ügyben hozott elsőfokú ítéletet a Borsod-Abaúj-Zemplén Megyei Bíróság iratellenesség, indokolási kötelezettség megsértése és megalapozatlanság miatt hatályon kívül helyezte, és az elsőfokú bíróságot új eljárás lefolytatására utasította. Az újabb elsőfokú ítélet valamennyi, közösség tagja elleni erőszakkal vádolt személyre végrehajtandó

\footnotetext{
56 2008. július 21-re virradó éjszaka lövéseket adtak le három, romák által lakott házra a Pest megyei Galgagyörkön, a támadásban senki nem sérült meg. 2008. augusztus 8-án a Szabolcs megyei Piricsén több Molotov-koktélt dobtak két, egymás mellett álló házra, majd lábon lőttek egy, a házból kilépő nőt. Szeptember 5-én Nyíradonyban lövéseket adtak le egy házra, amelyben romák aludtak, de nem sérült meg senki. Szeptember 29-én a Heves megyei Tarnabodon ismét Molotov-koktélokat dobtak és rálőttek romák házaira. 2008. november 3-án a Borsod megyei Nagycsécsen egy negyvenhárom éves férfi és egy negyven éves nő halt meg, amikor elöbb benzines palackokat dobtak a házukra, majd több lövést adtak le rá. Egy tizenkilenc éves fiatalember életveszélyesen megsérült, amikor 2008. december 15-én Alsózsolcán favágás közben rálőttek a saját háza udvarán. 2009. február 23-án, a Pest megyei Tatárszentgyörgyön egy férfit és ötéves kisfiát lőtték agyon, akik megpróbáltak kimenekülni felgyújtott házukból, két másik gyerek is megsérült. 2009. április 22-én este a Szabolcs megyei Tiszalökön agyonlőttek egy cigány férfit, aki éppen kilépett a saját háza ajtaján, hogy munkába menjen. 2009. augusztus 3-án a Szabolcs megyei Kislétán egy asszonyt megöltek, tizenhárom éves kislányát pedig életveszélyesen megsebesítették - sörétes puskával arcon lőtték - a támadók. Lásd például Tábori Zoltán: Cigány rulett, Budapest: Európa Könyvkiadó, 2014.

${ }^{57}$ Ålláspontom szerint a minősítés téves volt, tekintettel arra, hogy a közösség tagja elleni eröszak megállapításának feltétele, hogy a büncselekményt egy csoport elleni elöítélet motiválja. Jelen esetben azonban az elkövetőket nem elöítélet, hanem félelem, önvédelem motiválta.
} 
szabadságvesztés büntetést szabott ki. ${ }^{58}$ Ezzel a bíróság egy kisebbségeket védő szabályt a többséget védő szabállyá „alakított” és ekképp alkalmazott.

2013 októberében a Miskolci Törvényszék megváltoztatta az elsőfokú ítéletet, ${ }^{59}$ és kimondta: „,nem bizonyítható, hogy a vádlottakat a cselekmény elkövetésében magyarellenes érzület motiválta, ezért öket elsösorban garázdaság miatt terheli felelösség, és ennek megfelelöen a kiszabott büntetéseket enyhitette." ${ }^{\circ 0}$ A jogalkalmazás szempontjából előremutató, hogy a bíróság fontosnak tartotta, hogy a cselekmény motivációját egyenként vizsgálják a vádlottaknál. A bíróság megállapította, hogy nem bizonyítható az, hogy a ,halál a magyarokra” feliratú botot a vádlottak valamelyike készítette volna, és az sem, hogy azt a támadás során bármelyikük használta volna. Az sem volt bizonyítható, hogy az állítólagos magyarellenes fenyegetés a vádlottak valamelyikének szájából hangzott volna el, hiszen ismeretlen elkövetők is voltak.

A bíróság sajnos nem mondta ki, hogy a vádlottakat cselekményükben egy rasszista támadástól való félelem, és nem elöítélet motiválta, tehát emiatt sem lett volna megállapítható közösség tagja elleni erőszak, vagyis gyülölet-büncselekmény elkövetése. ${ }^{61}$ Jelen esetben figyelembe kellett volna venni azt a körülményt, hogy az eset csupán három héttel a tatárszentgyörgyi kettős cigánygyilkosság után történt, amikor a roma közösségekben rendkívüli feszült volt a légkör: országszerte esti járőrözéseket, egyéb önvédelmi akciókat szerveztek, újabb rasszista támadásoktól tartva. Jelen eset annyiban különbözik a fent ismertetett másik két esettől, hogy itt nem megtorlás iránti vágy vezetett a csoportok közötti konfliktushoz, hanem a gyülöletbüncselekmények miatti félelem által kiváltott önvédelmi reakciók jelentek meg - így ez az eset nem tekinthető gyülölet-büncselekménynek, mindazonáltal jól szemlélteti, hogy a gyülölet-büncselekmények magukban hordozzák annak veszélyét, hogy a

\footnotetext{
58 Társaság a Szabadságjogokért (TASZ): Miskolci ítélet: az ügyészség nem bizonyította a magyarellenes indítékot. http://tasz.hu/romaprogram/miskolci-itelet-az-ugyeszseg-nem-bizonyitotta-magyarellenesinditekot (2013. december 5.)

59 Miskolci Járásbíróság (megismételt I. fok) 22. B.2418/2011, Miskolci Törvényszék (megismételt II. fok) 3. Bf. 2023/2012.

${ }^{60}$ Társaság a Szabadságjogokért (TASZ): Miskolci ítélet: az ügyészség nem bizonyította a magyarellenes indítékot.

${ }^{61}$ Lásd uo. ill. Jovánovics Eszter-Pap András László: „Kollektív bünösség a 21. század Magyarországán: magyarellenesség vádja cigányokkal szemben két emblematikus perben” Fundamentum, 2013/3. 154.
} 
csoportok között ellenségeskedés, bizalmatlanság alakulhat ki, ami erőszakhoz is vezethet. $^{62}$

\subsection{Gyülölet-büncselekmények az emberi jogok szintjén}

A gyülölet-büncselekmények tehát jellegüknél fogva nem csupán az egyént, és a teljes közösséget, hanem, végső soron, a teljes társadalmat érintik, és mint ilyenek nem csupán büntetőjogi, de emberi jogi szempontból is megkülönbözött figyelmet érdemelnek, hiszen az egyenlőség elvének, valamint a diszkrimináció tilalma elvének súlyos sérelmével járnak ${ }^{63}$

Az emberi jogok szempontjából közelít a gyülöletvezérelte büncselekményekhez Sandholtz, ${ }^{64}$ aki „eröteljes és kitartó, kampányszerü emberijogsértési akciók”-ként (,,massive and sustantained campaings of human rights violation”) jellemzi a gyülöletbüncselekményeket. Ezen elmélet inkább a szisztematikus, szervezett erőszakra és elnyomásra - például a népirtás eseteire - vonatkozik. A marginalizált csoportokra például vallási csoportokra, etnikai és nemzeti kisebbségekre, szexuális kisebbségekre, őslakos csoportokra - nehéz terhet ró az állandó félelem, folyamatos fenyegetettség, a stigmatizáltság, a mindennapos zaklatások. ${ }^{65}$ Az ilyen típusú erőszakot - amikor egyes kisebbségi csoportok olyan rendszerességgel válnak verbális zaklatás, garázdaság vagy akár az életüket fenyegető támadások (pl. gyújtogatás) célpontjaivá, hogy nem látnak más esélyt, mint elhagyni a többségi, „fehér” közösséget - „elüző eröszak”-nak (,,movein violence”) tekinthetjük. Az ilyen kontextusokban a sorozatos gyülöletbüncselekmények hasonló megközelítésen és szándékon alapulnak, mint a genocídiumok: az elkövetők tudatosan és szisztematikusan választják ki az áldozatokat (azok feltételezett csoporthovatartozása alapján) ${ }^{66}$ - a megfélemlítés céljával.

\footnotetext{
62 Dinók 2013, 67.

${ }^{63}$ Barbara Perry-Patrik Olsson: "Hate Crime as a Human Rights Violation", in Barbara Perry and Paul Iganski (szerk.): Hate Crimes: The Consequences of Hate Crime, Vol 2, Westport: Praeger, 2009. 175.

${ }^{64}$ Wayne Sandholtz: „Humanitarian Intervention: Global Enforcement of Human Rights?” in Alison Brysk (szerk.): Globalization and Human Rights., Berkeley: University of California Press, 2002. 201225.

${ }^{65}$ Perry-Olsson 2009, 180.

${ }^{66}$ Perry-Olsson 2009, 181.
} 
Stanko a „célzott erőszak”-ra (,targeted violence”) vonatkozó elméletét arra használja, ${ }^{67}$ hogy megragadja a csoport tagjainak sebezhetőségét, amely a támadóhoz viszonyított hátrányos helyzetükből fakad. Ez a fogalom egyértelmüvé teszi, hogy az ilyen jellegü erőszakos cselekmények a hatalmi viszonyok rendszerében gyökereznek. Az efféle konfrontációk szükségképpen tükrözik a tágabb kulturális és politikai berendezkedésről, a jogokról, privilégiumokról.

Young a „rendszerszerü erőszak” (,systematic violence”) kifejezést használja, amely olyan - személy vagy dolog elleni - támadásokat takar, amelyeknek nincs más célja, mint a pusztítás, megalázás, rombolás. ${ }^{68} \mathrm{Ez}$ a fogalom is rávilágít a gyülöletbüncselekmények és az emberi jogok közötti kapcsolatra. Mindkettőt azzal a szándékkal követik el, hogy terrorizálják és ellehetetlenítsék az áldozatokat; azáltal, hogy megkérdőjelezik ,értéküket”. A gyülölet vezérelte erőszak több mint néhány, adott esetben rasszista egyén megnyilvánulása: normarendszereket, társadalmi feltételezéseket, magatartásokat, elveket jelképez, amelyek a faji és nemi egyenlőtlenségek újratermelésére, hierarchikus viszonyok fenntartására irányulnak. Az elkövetők az elnyomó erőszakot alkalmazzák saját megerősítésükre, annak érdekében, hogy nekik kedvező rendet alakítsanak ki. Az erőszak a hatalom iránti vágy megnyilvánulási formája, amely megfosztja az elnyomottat szabadságától és méltóságától, ${ }^{69}$ azaz megfosztja emberi jogaitól - adott esetekben pedig az életétől is. ${ }^{70}$

A kisebbségi csoportokkal szembeni gyülölet-büncselekmények és diszkrimináció minden társadalomban megtalálhatóak, csak a társadalmi válaszok eltérők. Ebből a szempontból kétféle társadalmat különböztethetünk meg: vannak a gyülölet iránt nyitottabb, illetve a gyülölettel szemben zártabb társadalmak. A gyülölettől elhatárolódó társadalmak problémaként kezelik a gyülölet motiválta cselekményeket, így egy ilyen társadalomban a rasszizmus legenyhébb megnyilvánulása is a munkahelyébe kerülhet valakinek. Az ilyen társadalmakban a rasszizmusra adott válasz nem feltétlenül csupán

${ }^{67}$ Lásd Elizabeth A. Stanko: „Re-conceptualising the Policing of Hatred: Confessions and Worrying Dilemmas of a Consultant" Law and Critique, 2001/13. 309-329.

${ }^{68}$ Iris Marion Young: „Five Faces of Oppression” in Dean Harris (szerk.): Multiculturalism from the margins, Westport: Bergin and Garvey, 1995. 65-86.

${ }^{69}$ Perry-Olsson 2009, 181.

${ }^{70}$ A fenti elméleteknek a gyülölet-büncselekmények jogi szabályozása kapcsán is kiemelt jelentösége van. Amikor a jogalkotó a védett csoportok kialakítását illetően dönt, akkor mindenképp érdemes figyelembe venni, hogy az adott társadalomban melyek azok csoportok, amelyek ilyen rendszerszintü erőszaknak áldozataivá válhatnak. Erre lásd a dolgozat $A$ hazai szabályozásról és jogalkalmazásról szóló fejezetet. 
jogi, hanem alapvetően kulturális kérdés is. Mindeközben a gyülöletre nyitott társadalmakban a polgári társadalmak alapvető értékei - például az egyenlőség korlátozottan vannak jelen, így ezen értékek megsértése esetén nem történik számonkérés a társadalom tagjai részéről. Nem meglepő, hogy e társadalmak esetében nehéz hatékony szabályozást kialakítani a gyülölet-büncselekményekkel szemben, hiszen a társadalom tagjai, így a jogalkotók sem értékelik alapvető jelentőségüként a szélsőségek és a gyülölet-büncselekmények elleni fellépést. ${ }^{71}$

Háborús időkben a gyülölet-büncselekmények rendkívül kegyetlen formában jelenhetnek meg. A boszniai etnikai tisztogatások idején például nők ezreit erőszakolták meg rendkívüli kegyetlenséggel és brutalitással szerb katonák, hogy megalázzák az áldozatokat, és - ahogy Neil Kressel szociálpszichológus rámutatott ${ }^{72}$ - így mutassák meg az ellensége csoporttal szembeni megvetésüket és undorukat. A gyülöletbüncselekmények többnyire aktuális társadalmi konfliktusokhoz kapcsolódnak, és az elkövetők célja az, megfosszák emberi méltóságuktól az áldozataikat. Ezen a ponton a gyülölet-büncselekményeket ismételten a szexuális erőszakkal kapcsolatos pszichológiai elméletekhez köthetjük, illetve ez a gondolatmenet visszavezet ahhoz, miszerint a gyülölet-büncselekmények a hatalmi viszonyok rendszerében gyökeredzik és egyfajta alá-fölérendeltségi helyzetet vázol. Hiszen a szexuális erőszak esetében gyakran hangoztatott érv, ${ }^{73}$ hogy a szexuális erőszak nem más, mint a hatalom gyakorlás eszköze. Ennek egyik legszemléltetőbb példája a férfi büntetés-végrehajtási intézeteken belüli szexuális erőszak, amely nem más, mint férfiak közötti hatalmi szerepek megtestesülése egy tekintélyelvü környezetben, ahol a fiatalabb, gyengébb elítélt arra kényszerül a külvilágban nökre „osztott” szerepet töltsön be az elnyomás rendszerében.

Az állam nem minden esetben tesz megfelelő lépéseket a gyülölet-büncselekmények megelőzése és felszámolása érdekében, és a „hanyagság” révén mintegy megtüri az erőszakot. Szemléletes példája az erőszak állam általi megtürésének a latin-amerikai utcagyerekekkel - a társadalom által kitaszított, az utcán élő, alvó, dolgozó gyerekekkel

${ }^{71}$ Krémer Ferenc hozzászólása, Magyar Tudományos Akadémia IX. Osztály Állam- és Jogtudományi Bizottság Rendészeti Albizottsága, 2013. március 8. A gyülölet-büncselekmények - dogmatika és joggyakorlat címü tudományos ülésen, ld. Dinók 2013, 52-67.

${ }_{72}$ Neil Kressel: Mass Hate: The Global Rise of Genocide and Terror, Cambridge: Westview Press, 2002. 13-45.

${ }^{73}$ Lásd: Susan Brownmiller: Against Our Will. Men, Women and Rape. New York: Simon and Schuster, 1975. 256-282. 
- szembeni erőszakhullám. ${ }^{74}$ Ezen gyerekek nagy része a családon belüli erőszak legkülönfélébb formái elől menekült el; elhanyagolás, mentális, fizikai és szexuális erőszak elől. Bogota, Rio de Janeiroé São Paulo bőséges példát szolgálnak a gyülöletbüncselekményekre, amelyet spanyolul ,limpieza social”, angolul pedig "social cleansing”-nek, azaz társadalmi tisztogatásnak is neveznek. Amint a gyülöletbüncselekmények minden formája, a társadalmi tisztogatás is a társadalom legsebezhetőbb csoportjai ellen irányul, olyanok ellen, akik már eleve kirekesztettek, diszkrimináltak és nem kívánatosak a társadalom számára szocioökonómiai státuszokból kifolyólag. A utcagyerekek folyamatosan rettegésben élnek, a felfegyverzett polgárőrök és rendőrök által megfélemlítve. Az ellenük elkövetett emberi jogi jogsértértéseket és gyülölet-bűncselekményeket rendkívül nehéz nyomon követni; sok esetben nem tesznek feljelentést az áldozatok, nincsenek szemtanúk sem, illetve, ezek az anonimitásba burkolózott gyerekek a társadalom peremén élnek, nincs semmilyen információjuk még arról sem, hogy hogyan tölthetnének ki egy formanyomtatványt vagy kérhetnének jogi segítséget. A „halálosztag”-okba (,death squad”) szerveződött elkövetők sokszor szolgálaton kívüli rendőrök, akiket helyi vállalkozások bérelnek fel (mert üzletmenetüket zavarja az utcagyerekek jelenléte), hogy „gondoskodjanak” a gyerekekről. A „társadalmi tisztogatás” lényegében az utcagyerekek és a prostituáltak megsemmisítésére irányul. A társadalom problémaként, zavaró körülményként tekint az utcagyerekekre, akik számára nincs kiépítve megfelelő támogató rendszer, amely biztosítaná számukra az emberhez méltó életet, életkörülményeket.

A gyülölet-büncselekmények kétségkívül tovább erősítik a kiegyensúlyozatlan erőviszonyokat a társadalom tagjai közötti. A gyarmatosító múltú nyugati kultúrák mint az Egyesült Államok, Nagy-Britannia, Kanada - példaként szolgálnak a mélyen beágyazott különbségeken, alá-fölérendeltségi viszonyokon alapuló társadalmi berendezkedésre, amely a kirekesztés és marginalizáció megerősödéséhez vezet illetve a társadalmi csoportok egymással való szembenállásához. Az ilyen társadalmakban ahogyan azt péládul Orwell leírja, ${ }^{75} \mathrm{a}$, ,kevésbé értékes” csoporthoz tartozókkal szemben

\footnotetext{
${ }^{74}$ Perry - Olsson 2009, 182.

${ }^{75}$ Lsd. például George Orwell: Burmai napok (ford. Máthé Elek), Budapest: Terebess Kiadó, 1998. 2425. ,„ Istenemre mondom, azt vártam volna, hogy amikor ilyen fontos kérdésröl van szó, mindnyájan gondolkodás nélkül mellém álltok. Elképzelhetetlenül szörnyü dolognak tartanám, ha ezeket a piszkos szineseket beengednénk magunk közé. Téged külön is kérlek, Flory, hogy ne sunyits. Igenis, szidom a feketéket, mégha a te drágalátos doktor kebelbarátodról van is szó. Semmi közöm sincs ahhoz, hogy kivel
} 
megengedett a rendszerszerű erőszak. A „különbözők rendszeré”-ben a felek szükségképpen besorolódnak a ,jók” és a „rosszak” kategóriájába. Ennek eredményeként a „másik” már nemcsak különböző, hanem a normáktól eltérő abnormális -, alárendelt. Az elnyomó rendszerek a dualizmus talaján müködnek: jógonosz, alá-fölérendelt, erős-gyenge stb. - és az egyik fél mindig az másikhoz viszonyítva létezik. ${ }^{76} \mathrm{Az}$ alárendelt csoport tagjai a „másik” státuszukból fakadóan potenciális áldozattá válnak. Az alárendelt csoporthoz tartozók esetében teljesen mindegy, hogy mit tesznek vagy nem tesznek, megfelelnek-e az „elvárásoknak” - így is, úgy is értéktelenek. Az erőszakos kölcsönhatások az alárendelt és domináns csoportok között olyan helyzetet eredményeznek, amelyben mindkét fél versenyez az előjogért, hogy a különbséget úgy definiálhassa, hogy azáltal állandósítsa a társadalmi erők hierarchiáját. Ebben a helyzetben a támadók igyekeznek megerősíteni a domináns szerepüket és előjogaikat a forrásokhoz való hozzáférésben, valamint korlátozni a "másik" csoport lehetőségeit a szükségletek kielégítése tekintetében. A gyülölet vezérelte erőszak megerősíti a fennálló alá-fölérendeltségi viszonyokat, korlátozza a „kevésbé értékesek” mobilitását, bizonytalanságban és félelemben tartja őket. Ez pedig az emberi jogok korlátozódásához vezet: ahogy Ashworth rámutat, ${ }^{77}$ a személyi szabadság és az emberi méltóság korlátozásának szélsőséges formája a megfélemlítés és az erőszak. A gyülölet vezérelte erőszak korlátozza és kényszeríti az áldozatot: a bántalmazó hatalmába kerül, gyakran fizikailag is képtelen a védekezésre vagy szökésre. A gyülölet-büncselekmények elkövetésének leggyakoribb forgatókönyve szerint általában több támadó áll szemben egy vagy két áldozattal - és valahogyan, valahonnan mindig elökerül egy újabb kéz, amely az áldozatot a földön tarthatja.

Szintén fontos szempont, hogy a gyülölet-büncselekmények az áldozat személyes szabadságát és mozgási szabadságát is korlátozzák. Ami az érzelmi következményeket

barátkozol a klubon kívïl. Ez egyedül a te dolgod. Mit bánom én, ha mindennap elmégy is Veraswami házába és együtt isztok whiskyt fekete kebelbarátoddal. De az egészen más dolog, ha azt akarnád, hogy az orvost ide hozd be közénk a klubba. Mondtam már és el fogom százszor is mondani, hogy lehetetlen magunk közé beengedni ezeket a pókhasú és fokhagymaszagú feketéket. Ha mégis ide mered közénk hozni, én leszek az elsö, aki szó nélkül kirúgom a klubból, hogy csak úgy repül.« Ellis hangos dührohama perceken át tartott. Gyülölete az ázsiaiak ellen öszinte és szenvedélyes volt. Mint fakitermelö vállalat alkalmazottjának, állandóan közvetlen összeköttetésben kellett állnia a burmaiakkal. De ez nem használt semmit és gyülölete a színesek ellen változatlanul vak szenvedélyként élt benne. Egyébként nagyon értelmes ember volt és munkáját tehetséggel végezte, de õ is azok közül az angolok közül való volt sajnos, ez a típus nagyon gyakori —, akiket soha nem szabadna kiengedni Anglia távolkeleti birtokaira."

${ }^{76}$ Perry-Olsson 2009, 184.

77 Lásd Georgina Ashworth: Of Violence and Violation Women and Human Rights, London: Change, 1986. 
illeti, az áldozatot sok esetben gyakorlatilag megbénítja a további bántalmazástól való félelem; ami attól is visszatarthatja, hogy a többségi társadalom tagjaival bármiféle kapcsolatot létesítsen. Az erőszak, illetve a fenyegetettség korlátozza az áldozat mozgásterét: úgy érezheti, hogy lehetőségei beszükültek, hogy kiszorul a társadalomból. A többségi társadalom előítéleti által sújtott amerikai őslakosok arról számolnak be, hogy félnek elköltözni a rezervátumból, vagy akár csak elhagyni a rezervátum. Állításuk szerint a rezervátumban élők azért nem keresnek kinn állást, mert közvetlen tapasztalataik, illetve családtagjaik, barátaik beszámolói alapján úgy ítélik meg, hogy túl sok kockázatot rejt számukra a külvilág. ${ }^{78}$

Tehát, a gyülölet-büncselekmények szándékolt eredménye az áldozat szegregálása és marginalizálása. A gettók kialakulásának történelmi gyökerei arra vezethetők vissza, hogy az embereket „biztonságos”, izolált zónákban tartsák, és az elkövetett erőszakos cselekmények hatására a csoport tagjai inkább az elszigetelt közösségi életet „válasszák”. Napjainkban a rasszista erőszak továbbra is ezt a szerepet tölti be, tekintve, hogy az erőszakos cselekmények jelentős része olyan kisebbségi egyének ellen irányul, akik meg merik tenni azt a lépést, hogy - átlépve a társadalmi határokat - beköltöznek egy „fehérek” által lakott szomszédságba. ${ }^{79} \mathrm{~A}$ lakhatási szegregáció veszélye, hogy megteremtheti, illetve megerősítheti a társadalomban a szegregáció és a marginalizáció mintázatait. A lakhatási szegregáció akadályát képezi a társadalmi mobilitásnak, ${ }^{80}$ mivel a lakóhely determinálja a további lehetőségeket: elzárhatja a gyerekeket a minőségi oktatástól, a büncselekmények számának növekedéséhez vezethet, korlátozhatja a közszolgáltatások való hozzáférést, végső soron generációkra előre meghatározhatja a szegregátumokban lakó emberek sorsát. A fizikai marginalizációnak egyenes következménye a társadalmi marginalizáció: olyan társadalmi határokat hoz létre, amelyeket az emberek nem mernek, és nem tudnak átlépni. Az ellenséges légkör, a zaklatás és az erőszak a Wachtel ${ }^{81}$ által felvázolt „önkéntes szegregáciő” (,voluntary segregation”) jelenségéhez vezet: a diszkrimináció és erőszak célpontjai inkább úgy döntenek, hogy nem hagyják el a viszonylagos biztonságot nyújtó közeget, ami pedig a gettósodás folyamatát eredményezi.

\footnotetext{
${ }^{78}$ Perry-Olsson 2009, 186.

${ }^{79}$ Perry-Olsson 2009, 186.

${ }^{80}$ Perry-Olsson 2009, 185.

${ }^{81}$ Paul L. Wachtel: Race in the Mind of America: Breaking the Vicious Circle Between Blacks and Whites. New York: Routledge. 1999. 221-222.
} 
Chapman megállapítása ${ }^{82}$ a nők elleni erőszakról - hogy globálisan elterjedt és sok esetben tolerált jelenségről, egyúttal súlyos emberi jogi jogsérelmekről van szó - a gyülölet-büncselekményekre is alkalmazható. A gyülölet-büncselekmények sértik az Emberi Jogok Egyetemes Nyilatkozatában lefektetett alapvető elveket. A gyülöletbüncselekmények az áldozat biztonsága és integritása ellen irányulnak; illetve arra, hogy fenntartsák a strukturális egyenlőtlenségeket a társadalom csoportjai között.

Ha a gyülölet-büncselekményekkel kapcsolatos diskurzust az emberi jogok szintjére emeljük, ezáltal elismerjük a fenyegetés komolyságát, amelyet a gyülöletbüncselekmények jelentenek. Ez a fajta erőszak nem csupán az egyén elleni erőszak, illetve és egyéni támadók szintjén létezik, hanem a társadalmi struktúrákban, hierarchizált viszonyokban gyökerezik. Ezért be kell látni, hogy a jogi mechanizmusok - még a legdemokratikusabb államok esetében is - önmagukban csupán korlátozott védelmet nyújthatnak az áldozatok számára, ám szimbolikus jelentőségük mindenképpen lehet. Noha a jog a védett csoportok számára akkor müködhet igazán, ha az érintettek rendelkeznek erőforrásokkal, befolyással és ismeretekkel, mindazonáltal tagadhatatlanul szerepe lehet a jognak a védelem kiterjesztése területén. Hasznos kiindulópont lehet a kirekesztés megnyilvánulási formái ellen irányuló jogalkotás annak érdekében, hogy az érintett közösségek ne stigmatizált, sebezhető csoportnak lássák önmagukat. A nyugati társadalmakban hagyománya van annak, hogy a kialakult helyzetet, a sürgető társadalmi problémákat jogszabállyal kíséreljék meg rendezni. A gyülölet-büncselekményekre vonatkozó jogalkotás üzenetet küld a társadalom számára, hogy mi a megengedhető és mi nem. Rendkívül komplex, a további fejezetekben részletezett kérdés, hogy a gyülölet-büncselekmények szankcionálása és a diszkrimináció állami tiltása, illetve az ezek elleni hatékony állami fellépés mennyiben jelent egyben társadalmi elutasítást is.

\subsection{A megkülönböztetett figyelem indokai}

Az elöítélet-vezérelte büncselekményeket hatásaik mellett éppen a fogalom lényegi eleme, a motiváció különbözteti meg más büncselekményektől, és ennek föként jogalkalmazási szempontból van jelentősége. Sok esetben a gyülöletvezérelte büncselekmény, így például a magyar közösség tagja elleni erőszak, a bizonyítás

82 Jane Roberts Chapman: "Violence Against Women as a Violation of Human Rights" Social Justice, 1990/2. 54. 
szempontjából különlegesnek számít, mert - a legtöbb büncselekménytől eltérően - a tényállás tisztázásához hozzátartozik az elkövető indítékának, motivációjának a bizonyítása is. A motiváció alapvetően az elkövető szubjektív tudati állapotához kapcsolódik, ebből fakadóan a büntetőeljárás során a motiváció bizonyítása számos nehézséget vethet fel. Miután a tudati állapot tartalmára vonatkozóan közvetlen bizonyítékot gyakran nem lehetséges találni, ezért az indíték feltárásánál az áltlagosnál is fontosabb a büncselekmény személyi és tárgyi oldali ismérveinek vizsgálata: ezek ugyanis azok ,a körülmények, amelyek objektívan megitélhetök, a külsö szemlélö által is érzékelhetöek és értékelhetöek". ${ }^{83}$ A sértett védett csoporthoz való tartozása és az elkövető cselekménye közötti okozati összefüggés fennálltának, az elöítéletes indítéknak vizsgálata során különlegesen fontos lehet az elkövető, illetve a sértett személye és az elkövetés körülményei. ${ }^{84}$ Nemzetközi útmutatók ${ }^{85}$ alapján ilyen alapvető jelentőségű faktor például: az áldozat és a szemtanúk beszámolója a büncselekményről; a feltételezett elkövető megjegyzései, gesztusai, amelyek elöítéletre utalhatnak; egybeesett-e a büncselekmény az érintett csoport/közösség valamilyen ünnepével vagy más kiemelt fontosságú eseményével; valamely szervezett gyülöletcsoport tagjainak a feltételezhető közremüködése vagy más motiváció - mint például nyereségvágy hiánya.

Összefoglalva a gyülölet-büncselekmények más bűncselekményekhez való különbségeit megállapítható, hogy:

- a gyülölet-büncselekmények súlyosabb hatásokkal jár mind az egyénre, mind a közösségre nézve pszichés-érzelmi, emberi jogi, társadalmi, gazdasági szempontból és üzenet-büncselekmény jellegükből fakadóan nem csupán az áldozatra és az érintett csoportra nézve fejtik ki hatásukat.

- a gyülölet-büncselekmények az egész társadalomra nézve komoly következményekkel járhatnak: magukban hordozzák annak veszélyét, hogy a csoportok között ellenségeskedés alakulhat ki, aminek következtében elszabadulhatnak az indulatok;

${ }^{83}$ Átol Dorottya [et al.]: „Közösség tagja elleni erőszak. Alternatív kommentár”, Fundamentum, 2013/3. 89.

${ }^{84}$ Átol [et al.] 2013, 89.

${ }^{85}$ International Association of Chiefs of Police (IACP): Responding to Hate Crimes: A Police Officer's Guide to Investigation and Prevention. http://www.theiacp.org/HateCrimesOfficerGuide (2015. február 5.) 
végső soron és mindezek következtében az ilyen jellegü büncselekmények súlyos közbiztonsági kockázatot jelentenek;

- a gyülölet-büncselekmények iránti kiemelt figyelem indoka többek között az is, hogy a motiváció mint lényegi elem kapcsán jelentős bizonyítási nehézségek merülhetnek fel, amelyet csak megfelelően képzett szakemberek képesek felismerni és kezelni. Emellett a motiváció alapján azért is sajátos büncselekmények, mert a szubjektív elem valamiképp objektivizálódik az áldozatok kiválasztása és az elkövető által reprezentált hatalmi dominancia révén. 


\section{A gyülölet-büncselekmények szabályozásának általános kérdései - érvek a kiemelt büntetőjogi figyelem mellett és ellen}

A gyülölet-büncselekmények fogalma az elmúlt két évtized során a világ számos részén tünt fel és eresztett gyökeret a politikai és jogi színtéren. Mára számos országban teremtették meg a gyülölet-büncselekményekre vonatkozó szabályozás alapjait, azonban még mindig heves viták zajlanak a szabályozás megfelelő módjairól, e módok alkotmányosságának kérdéseiről; illetve eleve a gyülölet-büncselekmények fogalmáról. Jelen fejezet azt próbálja meg bemutatni, hogy a jogalkotónak mely kérdésekben kell állást foglalni a gyülölet vezérelte büncselekményekre vonatkozó szabályozás kialakítása során, elsősorban az egyes szabályozási modellek és védett csoportok kapcsán. Ehhez kapcsolódóan pedig igyekszik rámutatni az egyes szabályozási modellek előnyeire és hátrányaira, valamint ismertetni a kiemelt büntetőjogi figyelemre vonatkozó különböző pro és kontra nézeteket.

\section{Egy társadalmi probléma visszaszorítása büntetőjogi eszközökkel}

A szabályozás megalkotásának nem csupán a gyülölet-bűncselekmények visszaszorítása lehet a célja, hanem egy toleránsabb társadalmi közeg megteremtése is: azáltal, hogy a különböző csoportok közötti erőszakot társadalmi problémaként kezelik, és ezzel egyfajta üzenetet küldenek az áldozat, az áldozati csoport, az elkövető és a társadalom számára. ${ }^{86}$ Így a gyülölet-büncselekményekkel kapcsolatos szabályozást a rasszizmussal, a homofóbiával, az antiszemitizmussal és hasonló jelenségekkel szembeni eszközként használják, azaz nem csupán a konkrét, erőszakos cselekményekben manifesztálódott intolerancia szankcionálására, hanem magának az intoleráns társadalmi közegnek a „kezelésére” is. Tagadhatatlan, hogy a gyülöletbűncselekmények az intolerancia erőszakos megnyilvánulási formái, és erre tekintettel elfogadhatónak tünik az az állítás, hogy hatásai nem csupán az egyéni áldozatot tekintve jelentősek, hanem a védett csoport és a teljes társadalom is érintetté válik, és így hatással lehetnek mind a közösségek közötti kapcsolatokra, mind a társadalmi stabilitásra.

\footnotetext{
${ }^{86}$ Lásd pl. Jacobs 2003, 409--426.
} 
Az előítélet állam általi elítélése fontos üzenetet közvetíthet az elkövető, a társadalom és áldozat, illetve a védett csoport tagjai felé: azt, hogy az ilyen cselekmények nem megtürtek egy demokratikus társadalom keretei között. ${ }^{87} \mathrm{Az}$ egyéni áldozatot ért sérelem elismerésével pedig az közvetíthető, hogy a bünügyi szervek védelmet biztosítanak, mind az áldozat, mind a csoport tagjai számára. Ha pedig elfogadjuk azt a nézetet, hogy a jog - különösen a büntetőjog - kifejezi a társadalmi értékeket, akkor a gyűlölet-büncselekmények szabályozása egyaránt jelzi az egyenlőség társadalmi értékének felismerését, támogatását és az előmozdítása iránti szándékot. ${ }^{88}$

A kontinentális jogokban a büntetőjog közvetíti a minimum morált. ${ }^{89}$ Ebből következően a büntetőjog értékvédő, értékteremtő és értékhordozó is. ${ }^{90}$ Ehhez az értékhordozó szerephez pedig azáltal jutott, hogy mindig függött az adott kor közjogialkotmányjogi rendszerétől. Éppen ezért és emiatt alakultak ki garanciális szabályai. A modern büntetőjog közjogi és alkotmányjogi függése mellett legitimitását azáltal is megalapozta, hogy a kor kultúrájának szellemét hordozta: a felvilágosodás eszméit, a humanizmust, a liberális toleranciát és a szabadságeszményeket. Korunkban, az alkotmányos jogállamok, a jogállami demokráciák korában, az emberi jogi és az alkotmányos alapjogok, amelyek védelme és amelyek követelményrendszerének beteljesítése a büntetőjog alapvető funkciója. ${ }^{91}$ Mindebböl kifolyólag pedig érdemes a büntetőjogra nem csak, mint az elrettentés-megtorlás területére, hanem a társadalmi értékek kinyilvánításának tartományára tekinteni.

A gyülölet-büncselekmények esetében tehát adott egy társadalmi jelenség, amelyre a normatív rendszer reagál valamiképp. Amikor a társadalmi kohézió nem müködik, illetve - a gyülöletvezérelte büncselekmények esetében - a legkevésbé müködik, a büntetőjog végső eszközként, értékvédőként és értékőrzőként vállalja magára az indulatok csatornába terelését.

A gyülölködő kifejezésekkel szembeni állami és társadalmi fellépés szükségességéről a magyar Alkotmánybíróság is kifejtette álláspontját az egyik gyülöletbeszéddel

${ }^{87}$ Lásd pl. Barbara Perry: „Counting - and Countering - Hate Crime in Europe”European Journal of Crime, Criminal Law and Criminal Justice 2010/4. 349-367.

${ }^{88}$ EBESZ/DIEJH 2009, 11.

${ }^{89}$ Belovics [et al.]: Büntetőjog I. - A 2012. évi C. törvény alapján. Budapest: HVG Orac Kiado, 2012.

${ }^{90}$ Bövebben lásd Németh Imre 2013, 361-368.

91 Szabó András: Recepció és kreativitás a büntetöjogban. http://www.philinst.hu/recepcio/htm/7/704.htm (2015. május 5.) 
kapcsolatos polgári jogi tárgyú határozatában. ${ }^{92}$ Álláspontom szerint a határozatban foglaltak a gyülöletmotiválta cselekményeket tekintve is helytállók. A határozatban foglaltak szerint a szabályozás célja, hogy védelmet biztosítson bizonyos közösségekhez tartozó egyének számára az adott közösséget sértő megnyilvánulásokkal szemben. Az ilyen megnyilvánulások

„, totalitárius ideológiák elemeit idézik, mivel egy adott közösség és az ahhoz tartozó egyének ellen irányulnak, a közösség és az ahhoz tartozó személyek identitását alapvetöen meghatározó tulajdonság becsmérlésével arra törekednek, hogy e közösséget és az ahhoz tartozó személyeket negatív színben tüntessék fel a társadalom elött. Ezzel pedig tudatosan és folyamatosan megkérdöjelezzék ahhoz való jogukat, hogy öket egyenlö méltóságúnak tekintsék, és ekként kezeljék. A tendenciózus magatartásokból összeálló folyamat szélsöséges körülmények között az adott közösség teljes kiszolgáltatottságához vezethet. Az ilyen megnyilvánulások elleni védekezés a társadalom közügye. Az ilyen megnyilvánulások ugyanis ellentétesek a demokratikus jogállamok értékrendjével". 93

Az Alkotmánybíróság tehát általánosságban véve a kirekesztő szóbeli megnyilvánulások szabályozása kapcsán fejtette ki véleményét, így ha a gondolatok és szóbeli megnyilvánulásaik kapcsán elmondható, hogy a társadalom közügye, akkor ezen kirekesztő nézetek erőszakos cselekményekben való megnyilvánulása esetén még fokozottabban indokolt a fellépés és a jogi szabályozás megalkotásának szükségessége az adott közösség védelme érdekében.

\section{A szabályozás modelljei}

\subsection{A szabályozási modellek büntetöjog-tudományi csoportosítása}

A gyülöletvezérelte büncselekmények szabályozása kapcsán elsőként az a kérdés tisztázandó, hogy van-e külön szabályozás az adott jogrendszerben. Ha nincs is külön gyülölet-büncselekményekkel kapcsolatos szabályozás, a jogalkalmazó akkor is súlyosító körülményként veszi figyelembe az elöítélet motivációt. A gyülöletvezérelte büncselekmények szabályozását tekintve eltérő modellek terjedtek el, amelyek a büntetőjog-tudomány által ismert fogalmak szerint két nagyobb egységre bonthatók: a

92 96/2008. (VII. 3.) AB határozat, ABH 2008. 816-837.

93 96/2008. (VII. 3.) AB határozat, 819. 
büntetési tételt érintő és nem érintő szabályozási típusok. Ennek megfelelően a jogalkotó az alábbi lehetőségek közül választhat:

A) Büntetési tételt érintő szabályozási megoldások

i. sui generis tényállás;

ii. minősítő körülmény és

iii. (általános részi) büntetési tételt megemelő rendelkezés.

B) Büntetési tételt nem érintő súlyosító körülményként való szabályozás.

A különféle szabályozási modellek megértéséhez először a büntetőjog-tudományban használt fenti kategóriák tisztázása szükséges.

A) Büntetési tételt érintő szabályozási megoldások

i) Sui generis büncselekmény, amely egy másik büncselekményhez hasonló képet mutat, de önálló büncselekményt képez. A gyülölet-büncselekmények esetében a jogalkotó alapul vesz egy már létező tényállást (leggyakrabban: garázdaság, testi sértés, rongálás stb.), és lényegében újrafogalmazza az elöítélet motiváció beillesztésével.

ii) Emellett számos büncselekménynek nemcsak az alapesetét határozza meg a törvény, hanem a minősített (súlyosabban minősülö) alakzatait is szabályozza. A jogalkotó úgyis dönthet, hogy egy büncselekmény különböző eseteihez eltérő büntetési tétel alkalmazását rendeli. A minősítő körülmények dogmatikai szempontból a tényállási elemek körébe tartoznak. $^{94}$ A minősített esetek törvényi meghatározása a büncselekmény tárgyára, az elkövetési módra, az elkövető személyét jellemző körülményekre, vagy a passzív alany sajátosságára tekintettel, valamint az alanyi oldalon jelentkező motívumok és célzat alapján törtéhet. ${ }^{95}$

iii) A határozott tartamú szabadságvesztés különös részben szereplő büntetési tételét a büntető törvénykönyvek általános (kevésbé gyakrabban különös) részének számos rendelkezése módosíthatja. ${ }^{96}$ A büntetési tételkeretet emelő rendelkezések mellett megkülönböztetjük az azt csökkentő rendelkezéseket is, amelyeknek a gyülölet-

\footnotetext{
${ }^{94}$ Lásd Kis Norbert-Hollán Miklós: Büntetőjog I., Az anyagi büntetőjog általános része - Alapismeretek a közigazgatási szakemberképzés számára. 2. átdolgozott kiadás, Budapest: Dialóg Campus Kiadó, 2013. 107.

95 3/2013. számú BJE határozat

${ }^{96}$ Lásd Kis-Hollán 2013, 267.
} 
büncselekmények súlyosabb büntetésének kérdéskörében nincs jelentőségük. A magyar Btk. alapján a szabadságvesztés büntetési tételének felső határát megemelő rendelkezések például: halmazati büntetés (Btk. 81. §), különös, többszörös, illetve erőszakos többszörös visszaesőkre vonatkozó szabályok (Btk. 89-90. §), illetve bűnszervezetben történő elkövetésnél alkalmazott szabályok (Btk. 91. §). ${ }^{97}$ A magyar Btk.-ban például a különös és a többszörös visszaesővel szemben az újabb büncselekmény büntetési tételének felső határa szabadságvesztés esetén a felével emelkedik (de nem haladhatja meg a huszonöt évet). ${ }^{98}$

B) Büntetési tételt nem érintő súlyosító körülményként való szabályozás

A büntetés kiszabás elsődlegesen a súlyosító és enyhítő körülmények figyelembevétele alapján történik. A súlyosító és enyhítő körülményeket együttesen szokták büntetést befolyásoló, illetve büntetéskiszabási körülményeknek nevezni. ${ }^{99}$ Az enyhítő és súlyosító körülmények a különös részben meghatározott tételkereten belüli „elmozdulásra” vannak hatással, az enyhítő körülmények az alkalmazásra kerülő mértéke lefelé befolyásolják, a súlyosítók pedig felfelé. ${ }^{100}$ A bíróság által megállapított minősítéshez kapcsolódó büntetési keret - figyelembe véve az általános rész rendelkezéseit is - jelöli ki azokat a határokat, amelyek között a súlyosító és enyhítő azaz a büntetést befolyásoló - körülmények a büntetést alakíthatják. ${ }^{101}$ A büntetést befolyásoló tényezőkről taxatív listát összeállítani szinte lehetetlen vállalkozás, mivel ugyanazon tény egy-egy cselekmény vagy elkövető kapcsán akár ellenkező hatású is lehet. A magyar Btk. még példálózó jelleggel sem határozza meg ezeket a körülményeket, azonban a Kúria Büntető Kollégiuma általános iránymutatást adott 56. BK véleményében, felsorakoztatva mindazt, aminek felderítését és értékelését a bíróságoktól indokoltnak tartja. Ehhez képest vannak olyan büntető kódexek, amelyek kifejezetten rendelkeznek a gyülölet motivációról mint súlyosító körülményröl, ezzel orientálva a jogalkalmazót. Az elöítélet motiváció mint súlyosító körülmény jogszabályban való tételes megjelölése képezi a negyedik szabályozási megoldást.

\footnotetext{
${ }^{97}$ Részletesebben lásd Kis-Hollán 2013. 247-248.

${ }^{98}$ Btk. 97. § (1) bek.

${ }^{99}$ Kis-Hollán 2013, 251.

100 Lásd bővebben: Molnár Sándor: „A büntetés kiszabása során figyelembe vehető körülmények” Jogi Fórum, 2011.

http://www.jogiforum.hu/files/publikaciok/molnar_sandor bunteteskiszabas\%5Bjogi_forum\%5D.pdf (2015. február 18.)

10156 . BK vélemény a büntetéskiszabás során értékelhető tényezőkről
} 
A két csoport elemei az alapján is csoportosíthatók, hogy a büntetőjogi felelősséget vagy jogkövetkezmények tanát érintőek-e. A büntetőjogi felelösség (a büncselekmény és a büntethetőség) ${ }^{102}$ körébe tartoznak általában a tényállási elemek, így a minősítő körülmények. Míg a büntetőjogi jogkövetkezmények tanába tartoznak az általános részben szereplő a büntetési tétel megemelő rendelkezések, illetve a súlyosító körülmények. $^{103}$ Mindazonáltal a büntetőjogi felelősség és a büntetőjogi jogkövetkezmények kérdéskörei között szoros összefüggés mutatkozik. Amint arra Hollán Miklós is rámutatott ,, a két téma elhatárolása amúgy is (...) viszonylagos, hiszen a minösitö körülmények (...) megvalósulása végső soron - az általános részben szereplö a büntetési tétel megemelö rendelkezésekhez egyébként hasonlóan - nem a büntethetöséget, hanem csak a szankció mértékét befolyásolja”. ${ }^{104}$

A magyar Legfelsőbb Bíróság gyakorlata alapján például az üzletszerüség a felbujtó vonatkozásában lehet büntetési tételt érintő (minősítő körülmény) vagy nem érintő (súlyosító) körülmény a tettesi cselekménytől függően. A Legfelsőbb Bíróság szerint „[a]mennyiben a felbujtó rendszeres haszonszerzésére törekedve több tettest bír rá [...] egy-egy olyan bűncselekmény elkövetésére, amelynek az üzletszerü elkövetés a minősítő körülménye, e minősített esetért felelősséggel csak akkor tartozik, ha az üzletszerüség a tettesi büncselekmény tekintetében is megállapítható. Egyébként a felbujtó ilyen magatartása kizárólag a büntetés kiszabása körében értékelendő. [...]"105 A részesség járulékosságából adódóan a részes cselekményének a jogi minősítése a tettes cselekményéhez igazodik, vagyis a tettes és a részes cselekménye ugyanannak a törvényi tényállásnak a keretei között minősül. ${ }^{106}$ Amint ezt a Legfelsőbb Bíróság többször kihangsúlyozta a bünrészesség - a felbujtás és a bünsegély is - mint járulékos jellegü közremüködés, a büncselekményben való tettesi alapcselekményt tételez fel, és csakis azzal összefüggésben valósulhat meg. ${ }^{107}$ A felbujtói cselekmények üzletszerüsége nem alapozza meg a Különös Részben üzletszerüen elkövetettként minősített eset megállapítását. Ugyanis a fentiekből eredően a felbujtó tényállási elemet nem valósíthat meg, márpedig az ületszerüség mint minősítő körülmény a törvényi

\footnotetext{
${ }^{102}$ Ezek viszonya vonatkozásában lásd Kis-Hollán 2013, 71.

${ }^{103}$ Hollán Miklós: „A személyes tulajdonságok és körülmények tana” in Hajdó József (szerk.): 90 éves a szegedi jogászképzés, Szeged, 2013. 61-82.

104 Hollán „A személyes tulajdonságok...” 2013, 63.

105 BJE 3/2011. II. pont

106 BH 2000/186

${ }^{107}$ BH 1999/53., 2000/185.
} 
tényállás része. A felbujtó a minősítő körülményért felelősséggel csak akkor tartozik, ha az üzletszerüség a tettesi büncselekmény tekintetében is megállapítható. Ennek hiányában az üzletszerüség értékelésére csak a büntetés kiszabására vonatkozó parifikációs rendelkezés keretei között van mód, a felbujtás üzletszerűségét súlyosító körülményként értékelve. ${ }^{108}$

2.2. A szabályozási modellek elterjedtsége, tartalma, valamint az egyes modellek elönyei és hátrányai

A legritkább megoldás szerint az elöítélet motiválta cselekmény a többi büncselekménytől elkülönült, sui generis tényállást képez. Erre a megoldásra találhatunk példákat Angliában ${ }^{109}$, Csehországban ${ }^{110}$ és Magyarországon ${ }^{111}$. A külön tényállás megalkotásának előnye, hogy ,gyülölet-büncselekmény”-ként (a magyar szabályozás például „közösség tagja elleni erőszak”-ként) nevezi meg az ilyen jellegü magatartásokat, és eleget tesz az oly sokszor hangsúlyozott szimbolikus funkciónak. A jogalkotó határozottabban fejez ki egy negatív értékítéletet, ha nem kizárólag a jogalkalmazásra bízza a motívum értékelését, hanem kifejezetten nevesíti azt. Ehhez képest pedig fokozottabban jelképes az állami elutasítás sui generis tényállásban szabályozott. A külön tényállás a megvetés szimbolikus kifejezésének leghangsúlyosabb formája, akár a társadalomnevelő-felvilágosító funkcióról (valamennyi állampolgár és az elkövető vonatkozásában egyaránt), akár az állami szolidaritás sértett irányába történő kifejezéséről szól. Végül az állam szimbolikusan azt is elismeri, hogy a társadalmi feszültségeket nem volt képes feloldani és ezeknek pusztán egy nem megválasztható tulajdonsága miatti csoport-hovatartozása miatt bárki áldozatává válhat. ${ }^{112}$

\footnotetext{
${ }^{108}$ BJE 3/2011. II. pont B) alpont

109 Lásd Crime and Disorder Act 1998. 29-32. $\quad$ szakasz. http://www.legislation.gov.uk/ukpga/1998/37/part/II (2014. június 15.)

${ }^{110}$ Btk. 352. §-a szabályozza egy csoport vagy annak tagja elleni erőszakot és fenyegetést

${ }^{111}$ Btk. 216. § Közösség tagja elleni erőszak

112 Bárd Petra: „A gyülölet-büncselekmények hatékony üldözésének társadalmi feltételrendszere” in Borbíró Andrea [et al.] (szerk.): A büntető hatalom korlátainak megtartása: a büntetés mint végső eszköz. Tanulmányok Gönczöl Katalin tiszteletére. Budapest: ELTE Eötvös Kiadó, 2014. 29-30. http://www.eltereader.hu/media/2014/05/Gonczol_READER.pdf (2015. március 5.)
} 
A külön tényállásban nevesítés megkönnyíti a statisztikai adatgyüjtést, valamint a külön hatásköri szabályok megalkotását is. ${ }^{113}$ Ezzel a típusú jogalkotással kapcsolatban azonban nehézségek is felmerülhetnek, hiszen az elkövetési magatartások rendkívül széles körét kell felölelniük a külön tényállásoknak, ideértve a személy és vagyon elleni büncselekményeket egyaránt. ${ }^{114}$ Emellett a motiváció kapcsán felmerülő bizonyítási nehézségek adott esetben „elriaszthatják” az ügyészséget a tényállás alkalmazásától. A legtöbb jogrendszerben a vádhoz kötöttségből kifolyólag a bíróság csak annak a személynek és csak azokért a cselekményekért való büntetőjogi felelősségéről dönthet, melyet a vádló a vádban indítványoz. ${ }^{115} \mathrm{Ez}$ pedig egyes jogrendszerekben annyira szüken értelmezett, hogy az adott esetben a bíróság kizárólag a vádban szereplő büncselekmény tekintetében állapíthatja csak meg a felelősséget, így ha a vádemelés a sui generis büncselekmény miatt történik, de a motiváció bizonyítása sikertelen, akkor a bíróság nem állapíthatja meg a felelősséget az alapbűncselekmény tekintetében. Éppen a motiváció bizonyítási nehézségeiből fakadóan az ügyészség végső soron elkerüli a gyülölet-büncselekmény tényállás alkalmazását és - az elkövető által többnyire beismert -alapcselekményt teszi a vád tárgyává. ${ }^{116}$

A második és egyben leggyakoribb szabályozási módszer ${ }^{117}$ valójában a három különböző megoldást tartalmazhat: minősítő körülményként; általános részi büntetési tételt emelő rendelkezésként; vagy súlyosító körülményként szabályozhatja a jogalkotó az elöítélet motivációt. Minősítő körülmény esetében az elöítélet motiváció a tényállás elemeként szerepel meghatározott különös részi tényállások keretében. Ezt a megoldást alkalmazza például részben a belga ${ }^{118}$, valamint a bosnyák büntetőkódex ${ }^{119}$. A büntetési

\footnotetext{
${ }^{113} \mathrm{Pl}$. a magyar szabályozásban a 25/2013 (VI. 24.) BM rendelet 1. mellékletének 13.1. pontja alapján megyei (fövárosi) rendörkapitányságok hatáskörébe tartozik a közösség tagja elleni erőszakkal kapcsolatos eljárások lefolytatása.

114 Gyülölet-büncselekmények Elleni Munkacsoport (GYEM): Az új Büntető Törvénykönyv gyülöletbüncselekményekre vonatkozó rendelkezéseinek kialakitása során figyelembe veendö szempontok, 2012, 11. gyuloletellen.hu/sites/default/files/hatteranyag_2012-02-22.pdf

115 Bővebben lásd: Belovics Ervin-Tóth Mihály: Büntető eljárásjog. Budapest: HVG-ORAC, 2013. 244 246.

116 Bővebben lásd Elizabeth Burney-Gerry Rose: "Racist offences - how is the law working? Implementation of the legislation on racially aggravated offences in the Crime and Disorder Act 1998", Home Office Research Study 2002. http://webarchive.nationalarchives.gov.uk/20110218135832/rds.homeoffice.gov.uk/rds/pdfs2/hors244.pdf (2015. február 24.)

${ }^{117}$ Lásd például EBESZ/DIEJH Hate Crime Laws... 2009, 33.

118 A belga büntetőkódex több tényállás esetében - többek között testi sértés, szexuális erőszak, emberölés - minősítő körülményként szabályozza az előítélet motivációt a szabadságvesztés büntetés kiszabása tekintetében. Emellett büntetési tételt emelő rendelkezéseket tartalmaz az intézkedések
} 
tételt emelő rendelkezést többnyire az általános részi rendelkezések között helyez el a jogalkotó, de elöfordulhat a különös rész rendelkezései között is. Utóbbit alkalmazza például a belga büntető törvénykönyv, elöírva, hogy bizonyos büncselekményeknél elöítélet motiváció esetén kétszeresére emelt intézkedési tételt alkalmazhat a bíróság. Végül súlyosító körülményként számos európai büntető törvénykönyv rendelkezik az elöítélet motivációról, így többek között a brit, spanyol és svéd kódex.

A súlyosító körülményként történő általános meghatározás elönye, hogy nem igényel átfogó kodifikációs tevékenységet, hiszen az előítélet motivációt csak egyszer, általános érvénnyel kell elhelyezni a büntető jogszabályokban. Hátránya, hogy a szabályozás a fent említett szimbolikus funkcióját kevésbé tölti be, és jelentősen megnehezíti a statisztikai adatgyüjtést, mert nem csupán egy tényállásnál kell nyomon követni az elöítéletes motivációt, hanem valamennyi szóba jöhető tényállás esetében. Ugyanezen hátrányok, ugyan kevésbé fokozottan, de a büntetési tételt megemelő rendelkezések vonatkozásában is elmondhatók. Minősítő körülményként szabályozás estében a szimbolikus funkció erőteljesebben érvényesül, mindazonáltal nehézségként merülhet fel annak eldöntése, hogy mely büncselekmények esetében indokolt a minősítő körülmény beillesztése. ${ }^{120}$

A harmadik megközelítés alapján a jogalkotó egyáltalán nem alkot a gyülöletbüncselekményekkel kapcsolatos szabályozást, hanem a meglévő jogszabályi keretek között veszi figyelembe az elöítéletes motivációt a büntetés kiszabása során. Megjegyzendő, hogy ebben az esetben is elöírható a jogalkalmazók számára a gyülöletbüncselekményekre vonatkozó adatgyüjtés. E modell előnyeként legfeljebb azt mondhatjuk el, hogy nem igényel kodifikációs munkát, ezzel szemben megnehezíti a statisztikai adatgyüjtést, és kiaknázatlan marad a szabályozás szimbolikus jellege. ${ }^{121}$

A fent ismertetett modellek nem feltétlenül tisztán léteznek, a gyakorlatban inkább a vegyes rendszerek jellemzőek. Így például a gyülölet-büncselekmények terén rendkívül kiépült szabályozással, átgondolt rendészeti szervezetrendszerrel, egyre szélesebb körü adatgyüjtési rendszerrel és számos jó gyakorlattal rendelkező Egyesült Királyság a

kapcsán, ahol többnyire kétszerezést ír elő. Lásd http://www.wipo.int/wipolex/en/text.jsp?file_id=262695 (2015. február 23.)

${ }^{119}$ Lásd EBESZ/DIEJH Hate Crime Laws ... 2009, 33.

${ }^{120}$ GYEM Az új Büntetö Törvénykönyv... 2012, 11.

${ }^{121}$ EBESZ/DIEJH 2009, 31-37 és GYEM Az új Büntető Törvénykönyv... 2012, 11-12. 
vegyes modellt követi. A jogi szabályozás három pilléren nyugszik az angol jogrendszerben: a rasszista és vallási elöítélet tanúsításával, illetve ilyen motivációból elkövetett testi sértés, rongálás, garázdaság és zaklatás sui generis tényállást képeznek; a rasszizmuson, vallási elöítéleten, szexuális irányultságon, fogyatékosságon, nemi identitáson alapuló ellenérzések súlyosító körülményt képeznek; továbbá arra az esetre, ha olyan védett csoport tagja a sértett, amelyet a jogszabály nem sorol fel, akkor külön rendelkezés tartalmaz iránymutatást a bíróságok számára súlyosító körülményként történő figyelembevételre.

Szintén vegyes és a magyar szabályozáshoz hasonló rendelkezéseket tartalmaz a cseh büntető törvénykönyv. A Btk. 352. §-ában sui generis tényállás keretében szabályozzák a fenyegetéssel és erőszakkal megvalósított gyülölet-büncselekményeket; minősítő körülményként szerepel az elöítélet motiváció például az emberölés (140. §) és testi sértés (145. §) tényállásában; végül súlyosító körülményként is megjelenik a 42 . § b) pontjában a büntetéskiszabás elvei között.

\section{A szabályozás kritikája}

A gyülöletvezérelte cselekmények más büncselekményekhez viszonyított különbségei képezik a szabályozásbeli megkülönböztetést. Sokat hangoztatott érv, ${ }^{122}$ hogy a gyülölet-büncselekmények súlyosabb hatásokkal járnak mind az egyénre, mind a közösségre nézve pszichés-érzelmi, emberi jogi, társadalmi, gazdasági szempontból. Emellett üzenet-büncselekményjellegükből fakadóan nem csupán az áldozatra és az érintett csoportra nézve fejtik ki hatásukat, hanem az egész társadalomra nézve komoly következményekkel járhatnak: magukban hordozzák annak veszélyét, hogy a csoportok között ellenségeskedés alakulhat ki, aminek következtében elszabadulhatnak az indulatok; végső soron és mindezek következtében az ilyen jellegü büncselekmények súlyos közbiztonsági kockázatot jelentenek. ${ }^{123}$

De a súlyosabb büntetési tétel igazolására például már gazdasági elemzés keretében is találhatunk példát. ${ }^{124} \mathrm{Az}$ alapfeltevés, hogy a lehetséges elkövető „haszna” az áldozat csoportidentitásában gyökerezik, és feltételezi, hogy a potenciális áldozatnak lehetősége

\footnotetext{
122 Bővebben lásd Iganski-Lagou 2009, 1-14; Lim 2009, 107-122; Lawrence 1999, 11; Danka 2009, 9296.

${ }^{123}$ Lásd pl. Perry-Olsson 2009, 175-192.

124 Dhammika Dharmapala-Nuno Garoupa: „Penalty Enhancement for Hate Crimes: An Economic Analysis"American Law and Economics Review, 2004/1. 185-207.
} 
van magára vállalni a társadalmi szempontból költséges, viktimizációt elkerülő tevékenységet. A vizsgálat eredménye alapján a gyülölet-büncselekmények aránytalan mértékben célozzák az adott csoportot és ezzel nagyobb károkat okoznak társadalmi szinten (még akkor is, ha elfogadjuk, hogy a gyülölet-büncselekmény áldozatát ért sérelem azonos a nem gyülöletmotiválta büncselekmény áldozatáéval).

A joggyakorlatot tekintve az Emberi Jogok Európai Bírósága Šečić Horvátország elleni ügyében ${ }^{125}$ rámutatott az államot terhelő kötelezettségekre előítéletes motiváció gyanúja esetén, és kifejtette, hogy ha az államok a faji indokból elkövetett eröszakot és brutalitást a nem rasszista indítékú bűncselekményekkel azonos módon kezelnék, azzal szemet hunynának az alapvető jogok érvényesülésére különösen veszélyes cselekmények sajátos természete felett.

A gyülölet-büncselekményekkel kapcsolatos jogszabályokra vonatkozóan számos kritika fogalmazódott meg. Ezek egy része eleve tagadja a megkülönböztetett figyelem szükségességét, illetve létjogosultságát, vagy éppen valamelyik szabályozási modell mellett/ellen érvelnek (külön tényállás vagy minősített eset), más részük a szabályozás alkotmányosságát vonja kétségbe vagy a súlyosabb büntetés indokoltságával száll szembe.

3.1. A gyülölet-büncselekmények és alapcselekmények egyénre, védett csoportra és társadalomra gyakorolt hatásával kapcsolatos érvek

A megkülönböztetett figyelem szükségességét tagadók körében ${ }^{126}$ általános érv, hogy nem bizonyított, hogy a gyülölet-büncselekmények nagyobb sérelmet okoznának az áldozatnak, mint a „hétköznapi” büncselekmények. Ezzel szemben egyrészt számos kutatás látott napvilágot, amely a sérelem fokozott súlyosságának feltételezését támasztja alá. Így például az említett British Crime Survey ${ }^{127}$ eredményei szerint a rasszista motivációból elkövetett büncselekmények áldozatainál intenzív érzelmi

\footnotetext{
${ }^{125}$ ECtHR, Case of Šečić v. Croatia, Judgement of 31 May 2007, No. 40116/02, § 67.

${ }^{126}$ Lásd pl. Heidi M. Hurd: „Why Liberals Should Hate »Hate Crime Legislation«”Law and Philosophy, 2001/2. 215-232. ill. Dan M. Kahan: „Two Liberal Fallacies in the Hate Crimes Debate”Law and Philosophy, 2001/2. 175-193.

1271982 óta folytatott, bűnözéssel kapcsolatos felmérés, amely Angliára és Walesre terjed ki, és amelynek során arról kérdezik a lakosság tagjait, hogy az elmúlt egy évben büncselekmény áldozataivá váltak-e; az egyes büncselekménytípusok elterjedtségének és természetének vizsgálata érdekében. A 2012. és 2013-as év során 50.000 háztartás vett részt a felmérésben, amely a fel nem jelentett esetekre is kiterjed. Lásd www.crimesurvey.co.uk.
} 
reakciók figyelhetők meg a büncselekményt követően, így többek között félelemérzet, sokk, depresszió, illetve alvási nehézségek. Herek, Gillis és Cogan ${ }^{128}$ összehasonlító kutatásokat végeztek meleg férfiak és leszbikus nők körében, és megállapították, hogy a homofób büncselekmények áldozatainál sokkal nagyobb arányban jelent meg depresszió, düh és poszttraumás stressz-zavar, mint a nem homofób büncselekmények meleg és leszbikus áldozatainál.

Emellett létezik olyan megközelítés, miszerint az elöítéletvezérelte büncselekmények speciális sérelmet okoznak, ${ }^{129}$ és ez indokolja a megkülönböztetett figyelmet és a magasabb büntetési tételt kiszabását. Az elmélet arra épül, hogy a leginkább sérülékeny csoportokkal szembeni erőszak történelmileg bevett eszköze a hierarchikus társadalmi viszonyok fenntartásának. A történelem során elnyomott csoportok hosszú ideje küzdenek annak érdekében, hogy közel egyenlö helyzetbe kerüljenek a többségi társadalom tagjaival; a gyülölet-büncselekmények által okozott speciális sérelem pedig éppen abban rejlik, hogy ezt az eleve bizonytalan státuszt kérdőjelezi meg, a közérdek pedig azt követeli, hogy az állam ezekkel szemben fellépjen, és biztosítsa az emberi méltóság elvének érvényesülést, valamint a hátrányos megkülönböztetéstől mentes együttélés feltételeit. ${ }^{130}$

A gyülöletvezérelte bủncselekményekkel kapcsolatos szabályozás támadható azon az alapon is, hogy „többet árt, mint használ a kisebbségek számára”. ${ }^{131}$ A gyülöletbüncselekményekkel kapcsolatos jogszabályok által biztosított védelem sok esetben nem csupán a tradicionálisan elnyomott, hátrányos helyzetü, sérülékeny csoportokra terjed ki, hanem a többségi társadalom tagjaira is. A tradicionálisan elnyomott csoportok, amelyeket látszólag védeni hivatott a szabályozás, olykor aránytalanul felülreprezentáltak elkövetőként, és ezért talán több elnyomást, mint védelmet teremt a szabályozás. ${ }^{132}$ Azonban a tradicionálisan elnyomott csoportok tagjainak statisztikákban elkövetőként való felülreprezentáltsága számos körülményböl fakadhat, így például a gyűlölet-büncselekmények statisztikáját leginkább befolyásoló tényezőből, miszerint a

\footnotetext{
${ }^{128}$ Iganski-Lagou 2009, 6.

${ }^{129}$ Karen Franklin: „Good Intentions: The Enforcement of Hate Crime Penalty-Enhancement Statutes"American Behavioral Scientist. 2002/1. 154-172.

${ }^{130}$ Franklin 2002, 166.

${ }^{131}$ Lásd pl. Gregory R. Nearpass: „The Overlooked Constitutional Objection and Practical Concerns to Penalty-Enhancement Provisions of Hate Crime Legislation"Albany Law Review, 2003/2. 547-573. ill. Franklin 2002, 154-172.

${ }^{132}$ Lásd Franklin 2002, 159-161.
} 
tradicionálisan elnyomott csoportok tagjai körében alacsony a jelentési hajlandóság. Emellett ez az érv nem is feltétlenül a gyülölet-büncselekményeknek szentelt kiemelt büntetőjogi figyelem indokoltságát kérdőjelezi meg végső soron, hanem egy másik vitához vezet, nevezetesen indokolt-e a tradicionális elnyomott csoportok mellett más csoportokat is védelemben részesíteni.

Mindemellett a szabályozás hatékonytalanságának látszatát keltheti, hogy egyre több gyülölet-büncselekmény jelenik meg a statisztikákban. ${ }^{133}$ Természetesen tagadhatatlan, hogy a statisztikák szerint minden országban történnek gyülölet-büncselekmények, és a regisztrált esetek száma többnyire emelkedő tendenciát mutat az elmúlt két évtizedben. Mindazonáltal azt is látni kell, hogy a hatékony adatgyüjtési rendszert alkalmazó államokban általában magasabb arányban jelennek meg a gyülöletvezérelte büncselekmények a statisztikákban, mint a kevésbé hatékony adatgyüjtést folytató államok esetében.

Az Európai Unió Alapjogi Ügynöksége (Fundamental Rights Agency -- FRA) három kategóriába sorolja az európai uniós tagállamokat a gyülöletvezérelte büncselekmények esetében érvényesülő hivatalos ${ }^{134}$ adatgyüjtési mechanizmusok szempontjából: 1 . átfogó adatgyüjtés, 2. jó színvonalú adatgyüjtés, 3. korlátozott adatgyüjtés. Az első kategóriába tartozó országok - mint az Egyesült Királyság, Finnország, Hollandia, Svédország esetében széles körben állnak rendelkezésre adatok a gyülölet-büncselekményekre vonatkozóan (pl. motiváció, büncselekmény típus, a büncselekmény jellemzői), és ezeket az adatokat nyilvánosságra is hozzák. A második csoportot alkotó államok mint például Ausztria, Belgium, Dánia, Lengyelország - többnyire nagy arányban rögzítenek adatot az elöítéletes motivációról, és többnyire nyilvánosságra is hozzák. Az utolsó csoportba tartozó országok - mint például Írország, Magyarország, Spanyolország - csak szűk körben gyüjtött, korlátozott esetszámra vonatkozó statisztikával rendelkeznek, és többnyire nem is publikálják ezeket az adatokat. ${ }^{135} \mathrm{~A}$ növekvő számok inkább utalhatnak az adatgyüjtési rendszerek egyre hatékonyabb működésére, mint a gyülölet-bűncselekmények előfordulásának drasztikus növekedésére.

\footnotetext{
${ }^{133}$ Lásd Franklin 2002, 160.

134 Hivatalos adat alatt a FRA azon adatokat érti, amelyeket valamely jogalkalmazási szerv gyüjt (rendőrség, ügyészség, bíróság), ill. egyéb államigazgatási szerv (pl. minisztériumok).

135 FRA: Making hate crime visible in the European Union: acknowledging victims' rights, $2012,36$. fra.europa.eu/sites/default/files/fra-2012_hate-crime.pdf (2014. március 30.)
} 
Azonban az egyre hatékonyabb adatgyüjtési rendszerek ellenére továbbra is rendkívül magas a gyülölet-büncselekmények látenciája. ${ }^{136}$ A Magyar Tudományos Akadémia Szociológiai Kutatóintézetének az Egyenlő Bánásmód Hatóság megbízásából készített jogtudatvizsgálat eredményei ${ }^{137}$ azt mutatják, hogy a sokoldalúan, rendkívül erőteljesen és differenciáltan elöítéletes magyar társadalomban jelen van az elöítéletes gondolkodás és a diszkriminatív magatartásra való hajlandóság. E magatartási formák minősített esetének, következő szintjének tekinthetjük a gyülölet-büncselekményeket is. A kutatás során a megkérdezettek tizenkét százaléka válaszolt igennel arra a kérdésre, hogy élete folyamán valaha érte már súlyos sérelem, erőszakos támadás vagy zaklatás valamilyen tulajdonsága miatt. A sérelmek leggyakoribb formája a szóbeli zaklatás volt, de a sérelem megnyilvánulásának formái között - a sérelmet elszenvedők arányának megfelelően - a tettleges bántalmazás és az erőszakkal fenyegetés is (azonos aránnyal) az ötödik helyen szerepelt. A válaszadók közül az erőszakos támadást, sérelmet elszenvedők alig tettek hivatalos panaszt. A panasztétel elmulasztását a következő okokkal magyarázták: senki sem tud rajtuk segíteni; nem tudják, pontosan kihez fordulhatnának; a történetet utólag bagatellizálták, sérelmüket az áldozatok később a valóságosnál kisebbként észlelték. ${ }^{138}$

A gyülölet-büncselekmények látenciája mögött számos oka húzódik meg, amelyek közül a legjelentősebbek: az állampolgárok jogismeretének hiánya; szégyenérzet; félelem a védett tulajdonság kiderülésétől; hatóság elöítéletes fellépésétől (másodlagos viktimizációtól) való félelem; a hatóságok munkájába vetett alacsony bizalom; illetve a különféle jogalkalmazói anomáliák (alulminősítés, rendőri intézkedések elmulasztása stb.). ${ }^{139}$ A jogalkalmazói anomáliák mellett ${ }^{140}$ a közintézmények, a közhatalom reprezentánsai iránti bizalom alacsony szintjének van jelentős hatása a látenciára. A magyar társadalom alapvetően bizalmatlan. Ez a magánszemélyek egymás közötti

\footnotetext{
${ }^{136}$ Lásd bővebben Jan van Dijk [et al.]: The Burden of Crime in the EU. Research Report: A Comparative Analysis of the European Crime and Safety Survey (EU ICS) 2005. http://www.unicri.it/services/library_documentation/publications/icvs/publications/EUICS__The_Burden_of_Crime_in_the_EU.pdf (2015. március 10.) ill. Dombos 2013.

${ }^{137}$ Neményi Mária [et al.]: Az egyenlö bánásmóddal kapcsolatos jogtudatosság növekedésének mértéke fókuszban a nők, a romák, a fogyatékos és az LMBT emberek. Kutatási zárójelentés. Budapest, 2011. április 30. http://www.egyenlobanasmod.hu/tamop/data/MTA_1hullam.pdf (2015. március 10.)

${ }^{138}$ Uszkiewicz Erik: „Mit (nem) mutatnak a számok?” Belügyi szemle, 2013/12. 84-85.

139 Lásd például: Shea W. Cronin [et al.]: „Uncertainty, and Infrequency in Eight Police Departments Bias-Crime Reporting: Organizational Responses to Ambiguity” American Behavioral Scientist, Vol. 51. 2007. 213-231.

${ }^{140}$ A jogalkalmazási problémákkal a dolgozat A hazai szabályozásról és jogalkalmazásról c. fejezete foglalkozik részletesen.
} 
viszonyaiban is kimutatható, de megnyilvánul a közintézményekre vonatkozóan, így a rendőrség esetében is. Egy 2010-es felmérés eredményei azt mutatják, hogy a bizalmatlanság apátiával, lemondással és az állami mechanizmusok elleni hatástalanság érzésével párosul. Az igazságszolgáltatás elfogadottságával kapcsolatos kérdésekre adott válaszok alapján alapvetően a következő attitüdök voltak meghatározóak: szkepticizmus, bizalmatlanság, negatív értékelés, az igazságosság iránti erős vággyal szemben álló jogszerüség, direkt befolyásoltság és az egyenlőség követelményének hiánya. ${ }^{141}$ Ezek a magyar társadalomnak az igazságszolgáltatással kapcsolatos meggyőződései, amelyek a gyülölet-büncselekmények esetében a fokozott sérülékenység és az említett hatások miatt még jelentősebben befolyásolhatja az áldozatok jelentési hajlandóságát.

\subsection{Alkotmányellenesség, a szólásszabadság határa}

Az elöítéletvezérelte büncselekmények súlyosabb büntetése megkérdőjelezhető abból a szempontból is, hogy vajon összeegyeztethetö-e a szabályozás az alkotmányos mércékkel. Kérdésként vetődik fel, hogy a gyülölet-büncselekmények súlyosabb büntetéssel fenyegetése indokolatlanul korlátozza-e a szólásszabadságot. A korlátozó jelleg mellett érvelők ${ }^{142}$ párhuzamot vonnak a gyülöletbeszéd és a gyülöletbüncselekmények között, és utóbbira is érvényesnek tekintik bizonyos mértékben a gyülöletbeszéd esetében már részletesen kimunkált elveket. Természetesen az alapul szolgáló tényállás büntetésének szükségességét nem, csupán a büntetés súlyosításának lehetőségét vitatja ez a megközelítés, amely szerint a gyülölet-büncselekmények esetében az elkövető cselekményével lényegében véleményét, meggyőződését juttatja kifejezésre az elöítélet formájában.

Az egyik legtöbbet hivatkozott ügy, ahol felmerült a gondolat büntetésének kérdésköre, az amerikai legfelső bíróság korábban hivatkozott Wisconsin kontra Mitchell ügye (Todd Mitchellt két év letöltendö börtönbüntetésre ítélték súlyos testi sértés miatt, és további két évre az előítéletes motiváció miatt). Az ügy során a vádlott védője kifejtette, hogy a gyülölet-büncselekményekkel kapcsolatos szabályozás a - kormányzat által helytelenített - gondolatot bünteti. A védő álláspontja szerint a vádlott elöítéletes

\footnotetext{
${ }^{141}$ Uszkiewicz 2013, 88-90.

${ }^{142}$ Lásd pl. Tim J. Berard: „Hate Crimes and Their Criminalization” Research in Social Problems and Public Policy, 2010/17. 24-27; Nearpass 2003, 554-558; Kahan 2001, 184--192.
} 
nézetei durvák és visszataszítóak ugyan, de ha Mitchellt a nézetei miatt büntetik, akkor fel kell készülni arra, hogy bármely más nézeteket is büntetni fognak. A védő a gyülöletvezérelte büncselekmények büntetésére úgy tekint, mint a szólásszabadság korlátozására.

A védelem álláspontjára tekintettel a bíróság nem kerülhette el a gyülöletbüncselekmények büntetése és az Alkotmány szólásszabadságról szóló Első Kiegészítése kapcsolatának vizsgálatát. A bíróság e kapcsolatot tekintve két kérdésre is kitért: egyrészt arra, hogy a gyülölet-büncselekmény nem puszta véleménynyilvánítás, másrészt arra, hogy alapvetően elfogadott, hogy a jogalkalmazó figyelembe vesz olyan látszólag szubjektív körülményeket is, mint a szándék, illetve motívum. A bíróság az első érv kapcsán idézte a Roberts kontra United States Jaycees (1984) precedensben kifejtetteket, miszerint az erőszak és más cselekmények, amelyek a kommunikációs hatástól elkülönülő speciális sérelmet okoznak, nem jogosultak az alkotmányos védelemre. Tehát, adott esetben egy büncselekmény kifejezi ugyan az elkövetőnek egy másik személlyel szemben meglévő elöítéleteit, de ugyanakkor a kommunikációs hatástól elkülönülő sérelmet is okoz, és ez az, ami a véleménynek biztosított alkotmányos védelmet megszünteti. A második érv kapcsán a bíróság kimondta, hogy az ítélkező bíró minden esetben számos tényezőt értékel a bünösség eldöntése körében, és e tényezők egyike a motívum. A bíróság megjegyezte, hogy az első alkotmánykiegészítés nem tiltja a beszéd felhasználását a szándék vagy motívum bizonyítása kapcsán. ${ }^{143}$

Tehát az amerikai legfelső bíróság úgy foglalt állást, hogy ha el is fogadjuk a gyülöletbűncselekmények esetében, hogy az elöítélet egyfajta vélemény, az nem jogosult az alkotmányos védelemre, ha a verbális véleménynyilvánítás erőszakos cselekménnyel párosul. A szólásszabadsággal való összeegyeztethetőséget az amerikai legfelső bíróság mondta ki, annak ellenére, hogy a társadalmi rendet megzavaró kifejezések korlátozhatóságát tekintve az Egyesült Államok jogrendszere igen sajátos megoldást alakított ki. E kifejezések ugyanis példátlanul széles védelmet élveznek az Egyesült Államokban; olyannyira széles védelmet, hogy az európai mércével idegenül is hathat, noha a megközelítés egyes elemei megjelentek az európai kontinensen. ${ }^{144}$ Éppen a

\footnotetext{
${ }^{143}$ Berard 2010, 25-26.

${ }^{144}$ Koltay András (szerk.): A gyülöletbeszéd korlátozása Magyarországon. Budapest: CompLex, 2013. 138.
} 
példátlanul szükre szabott amerikai korlátozási keretek miatt lenne nehéz úgy érvelni, hogy más országok jogrendszerében nem állja meg a helyét a szólásszabadsággal való alkotmányos összeegyeztethetőség a súlyosabb büntetéstilletően. Hiszen amennyire közkedvelt hivatkozási alap az amerikai „,clear and present danger” („,nyilvánvaló és közvetlen” vagy „világos és jelenvaló” veszély) mércéje ${ }^{145}$ a szólásszabadság korlátozása esetén - mint legszigorúbb viszonyítási alap -, úgy a gyülöletbüncselekmények szólásszabadságot nem korlátozó jellege esetében is érdemes lehet figyelembe venni az amerikai ítéletben foglalt álláspontot.

\subsection{Az elkövetö „, személyiségének” büntetése}

Egy másik megközelítés szerint azért megengedhetetlen a magasabb büntetési tétel, mert azok a szankciók, amelyek egy személy nézeteit célozzák, egyben a természetét is célozzák, és igazságtalanul fókuszálnak egy személy olyan tulajdonságaira, amelyek felett nem rendelkezik ellenőrzéssel. ${ }^{146}$ A szabályozás a tudati állapot mellett figyelembe veszi az elkövető bizonyos személyes tulajdonságait, és lényegében egy nemkívánatos tulajdonsága miatt bünteti. A kiindulópontot az jelenti jelen esetben, hogy a gyülölet-büncselekményhez kapcsolódó tudati állapot nem esetiként jellemezhető, hanem egy, az idők folyamán a személyiséggel együtt kialakuló állandó állapotról beszélhetünk. Noha valóban nehezen elképzelhető, hogy valaki csupán egyszeri alkalommal érez gyülöletet egy adott csoport - és így a csoport tagja - iránt, de ez nem igazolja az álláspont megalapozottságát.

Az egyik legextrémebb megközelítés Heidi Hurdtól származik, ${ }^{147}$ aki szerint a gyülöletbüncselekményekkel kapcsolatos szabályozás az érzelmekre fókuszál, és az ilyen érzelem inkább állandó, a személyiségez tartozó ismertetőjegy, mint aktuális tudati állapot. A szerző a gyávasághoz hasonlítja a gyülöletet; annyiban, hogy a gyávaság például, arra készteti az embert, hogy bizonyos szituációkat elkerüljön, és ugyanúgy nem kontrollálható, akár a gyülölködés. Mivel álláspontja szerint az ilyen tulajdonságok szorosan kötődnek az egyén jelleméhez, ezért a jogszabály a gyülölet-büncselekmény elkövetőjét „rossz tulajdonsága” miatt bünteti. Hurd azt hangsúlyozza, hogy a „rossz

145 Magyar joggyakorlatban való megjelenésére lásd például Koltay András: „A nagy magyar gyülöletbeszéd-vita: A »gyülöletre uszítás« alkotmányos mércéjének azonosítása felé” Állam- és Jogtudomány, 2013/1-2. 91-123.

${ }^{146}$ Mohamed Al-Hakim: „Making Room for Hate Crime Legislation in Liberal Societies”Criminal Law \& Philosophy, 2010/3. 341.

${ }^{147}$ Lásd Hurd 2001, 215-232. 
tulajdonságainkat" nem tudjuk kontrollálni, mert elválaszthatatlanul kapcsolódnak a jellemünkhöz. Ebből fakadóan pedig az állam szükségszerűen ,jó és rossz” értékek és gondolatok közötti döntést is hoz, mert egyben az elkövető által vallott értékeket is bünteti, és ezért végső soron a jogszabály ellentétben áll a politikai liberalizmus alapelveivel. Hiszen az állam nem csupán azt határozza meg, hogy mit tehetünk, hanem azt is, hogy kik lehetünk. A Rawls által felvázolt politikai liberalizmus ${ }^{148}$ alapgondolatából indul ki, miszerint az állam a társadalmi együttélés kereteit szabhatja meg, de teret kell hagynia az állampolgárok számára az egyéni jóról vallott nézeteik kialakítására. Álláspontja szerint az, hogy valakit a „rossz tulajdonságaiért” büntet az állam, szükségszerüen együtt jár azzal, hogy a jóról vallott nézeteit bünteti, mert nem hagyja meg a teret számára arra, hogy szabadon vallhasson adott esetben rasszista nézeteket, és végső soron ez összeegyeztethetetlen a liberális eszmékkel. ${ }^{149}$

A Hurd által képviselt álláspont kritikájának kiindulópontja, hogy az elmélet azért megalapozatlan, mert feltételezi, hogy a személyes tulajdonságaink és a jellemünk, illetve a jóról vallott nézeteink teljes egészében egybeesnek. Az ellenkező álláspontot képviselő Mohamed Al-Hakim ${ }^{150}$ a kanadai Alberta állam fellebbviteli bíróságának $R$. kontra Sandouga ügybenhozott ítéletén keresztül mutatja be, hogy a két fogalom nem esik teljesen egybe. Yousef Ishag Sandouga gyülölet által motiválva Molotovkoktélokkal gyújtott fel egy edmontoni zsinagógát, ezzel kívánva hangot adni a zsidó közöséggel szembeni dühének. ${ }^{151}$ A bíróság döntése nem az elkövető jóról vallott nézeteit vagy értékeit, hanem csupán a személyiségének azon részét érintette, amely a bűncselekmény elkövetésére késztette. A bíróság nem vette figyelembe ugyanis az elkövető muzulmán közösséghez való tartozását, világnézetét - amely vallási nézeteiből fakadt -, de végképp nem a jóról való nézeteit bírálta vagy mérlegelte (így például a családról, vallásról alkotott nézeteit vagy erkölcsi értékrendszerét), hanem a zsidó

\footnotetext{
${ }^{148}$ A politikai liberalizmusnak arra szabad törekednie, hogy az igazságos együttmüködés feltételeit kereső egyének megegyezhessenek az elveiben. Rawls kifejezésével élve: ,a politikai elmélet megvan az igazságra vonatkozó elképzelés nélkül.” Azaz a politikai liberalizmusszerint „az egyenlő bánásmód követelményéből egy kétágú semlegességi elv következik. Egyik ága az a norma, amely megtiltja az államnak, hogy polgárai közt meggyőződéseik és életfelfogásuk alapján tegyen különbséget. Másik ága azon a megfontoláson nyugszik, mely szerint az állami aktusok igazolásának közös alapokra kell épülnie: mivel az átfogó doktrínák nem szolgálhatnak közös alap gyanánt, ezért - így Rawls - vitáikban az igazolásnak semlegesnek kell lennie”. Lásd Kis János: „Az állam semlegessége. Újabb nekifutás” Fundamentum, 2011/3. 10.

${ }^{149}$ Lásd Hurd 2001, 222--229.

${ }^{150}$ Al-Hakim 2010, 350.

151 Bővebben lásd www2.albertacourts.ab.ca/jdb/1998-2003/ca/Criminal/2002/2002abca0196.pdf (2014. május 5.)
} 
közösséggel szemben tanúsított magatartását értékelte. ${ }^{152}$ Ez a megközelítés természetesen nem a jóról vallott nézeteink és a jellemünk közötti kapcsolatot tagadja, csupán azt, hogy a kettő teljes egészében egybeesik.

A különbséget Al-Hakim két hipotetikus esettel szemlélteti. ${ }^{153}$ Az egyik eset szereplője Sami, aki számára az elsődleges értéket a másoknak való segítségnyújtás jelenti, és emiatt tüzoltó szeretne lenni -- hogy vészhelyzetben lévő embereknek segíthessen. A terve egybeesik az általa vallott értékekkel, de van egy probléma: vészhelyzetben rendszerint megijed, és leblokkol. Ezt a hátráltató tulajdonságát felismerve mindent megtesz annak leküzdése érdekében; még hipnózisnak is aláveti magát. A másik képzeletbeli eset szereplője Omar, aki hithű muzulmán, és a vallási tanításokat tekinti az élete elsődleges értékeinek, így ezeknek megfelelően kíván békességben élni. Rájön viszont arra, hogy zsidók jelenlétében dühöt érez. Nem kedvelve e tulajdonságát, mindent megtesz annak érdekében, hogy a vallásról - és annak fényében a békességről - vallott nézeteinek megfelelően éljen, és igyekszik úrrá lenni a zsidókkal szembeni ellenérzésein. ${ }^{154}$

A két eset szemlélteti, hogy a jóról vallott nézetek inkább az elvek, értékek területén mozognak, míg a tulajdonságaink bizonyos magatartásra, cselekményekre késztetnek. Mindkét képzeletbeli személy észlel magában egy nemkívánatos tulajdonságot, amelyek összeegyeztethetetlenek a jóról vallott nézeteikkel. Ezzel mutat rá a szerző arra, hogy az értékrendszer és a tulajdonságok kölcsönösen befolyásolják egymást, de korántsem azonosak; és ez alapján vonja kétségbe, hogy a „rossz tulajdonságok” büntetése az értékrendszer büntetését, illetve a liberális eszmék megsértését jelentené.

Emellett a szerző arra is rámutat, hogy a Hurd által képviselt nézet filozófiai és jogi abszurdumhoz vezet: azt feltételezni ugyanis, hogy a tulajdonságaink olyan mértékben meghatározzák cselekedeteinket, hogy azok felett lényegében ellenőrzéssel sem rendelkezünk, már-már azt sugallja, hogy még talán enyhébben is kellene büntetni a gyülöletvezérelte büncselekményeket. Tehát például egy antiszemita személy, aki gyülölettől vezérelve bántalmaz egy zsidót, lényegében nem rendelkezik választási lehetőséggel, azaz erkölcsileg nem tekinthető felelősnek. Egy homofób büncselekmény

\footnotetext{
${ }^{152}$ Al-Hakim 2010, 350.

${ }^{153}$ Lásd Al-Hakim 2010, 350--351.

${ }^{154}$ Lásd Al-Hakim 2010, 351.
} 
elkövetője pedig érvelhetne azzal, hogy homofób környezetben nőtt fel, mindvégig arra tanították, hogy a homoszexualitás rossz, erkölcstelen, és emiatt vált homofóbbá: a környezetét nem maga választotta, hanem beleszületett, és erre tekintettel enyhébb büntetést érdemelne. ${ }^{155}$

Ez pedig továbbgondolva akár a büntetőjog felelősségi rendszerének alapjaiban való megkérdőjelezését jelentené: hiszen annak a feltételezése, hogy bizonyos tulajdonságaink felett annyira nincs ellenőrzésünk, hogy a büncselekmény elkövetésétől való tartózkodás sem várható el az érintettektől, azt sugallná, hogy a személyiségjegyek bünösséget kizáró oknak számíthatnak. Ha a jogalkotó a tényállásszerü és jogellenes cselekmény elkövetőjét nem kívánja büntetőjogi jogkövetkezményekkel sújtani, akkor ezekre a kivételes szituációkra bünösséget kizáró okot alkot. Amint erre a magyar büntetőjog általános részi tankönyvek rámutatnak, ezek „a bünösséget kizáró okok alapvetően olyan pszichés állapotot írnak le, amely miatt a tényállásszerü és jogellenes cselekménytől való tartózkodás az elkövetőtől nem várható el”, „más esetekben a bünösséget kizáró okok olyan objektív szituációkat szabályoznak, amelyeknél a jogalkotó a tényállásszerü és jogellenes cselekménytől való tartózkodást nem tartja elvárhatónak" 156 Ilyen például a magyar jogban, amikor valaki elmebetegségére tekintettel képtelen cselekménye következményeit számításba venni, más esetekben a bűnösséget kizáró okok olyan objektív szituációkat szabályoznak, amelyeknél a jogalkotó a tényállásszerü és jogellenes cselekménytől való tartózkodást nem tartja elvárhatónak. Ilyen esetekben a bünösség akkor is kizárt, ha az elkövető in concreto olyan pszichés állapotban van, amely alapján elvárható lenne tőle a jogszerü magatartás. Így például a tizenkettedik vagy tizennegyedik életévét be nem töltött gyermek nem büntethető, akkor sem, ha belátja cselekménye jogellenes (tiltott) jellegét -- például egy tíz éves elkövető a rablásét. Azonban a magyar jogrendszerben ismert bünösséget kizáró okok $^{157}$ egyike sem fedi le a személyiség feletti kontroll hiányát. Abszurd maga a felvetés is, hogy például egy féltékenységre hajlamos személytől nem várható el a féltékenység kontrollálása, és amennyiben féltékenység által vezérelve lelövi vetélytársa

\footnotetext{
${ }^{155}$ Lásd Al-Hakim 2010, 352.

${ }^{156}$ Lásd pl. Hollán Miklós-Kis Norbert: Büntetőjog I. -- Az anyagi büntetőjog általános része, Büntetőjogi ismeretek a közszolgálati szakemberképzés számára. Budapest: Dialóg Campus, 2008. 154-156.

157 Gyermekkor, kóros elmeállapot, kényszer és fenyegetés, jogellenesség hiányában való tévedés, az elhárítás szükséges mértékének túllépése jogos védelemnél, a mentési (menekülési) cselekmény arányosságának túllépése, ill. a különös részben szabályozott bünösséget kizáró okok. Lásd Hollán-Kis 2008, 154-156.
} 
gyermekeit, az aljas indokot nem minősített esetként szabályozná a jogalkotó, hanem egyenesen büntethetőséget kizáró okként -- ami persze képtelenség lenne; erre utal AlHakim is azzal, hogy a Hurd által felvázoltak filozófiai és jogi abszurdumhoz vezethetnek.

Mindezek alapján szükséges látni azt, hogy a gyülöletvezérelte büncselekmények esetében sem a gyülölködő gondolatot vagy a gyülölködő, „rossz személyiséget” rendeli büntetni a jogalkotó, hanem azt, hogy valaki gyülölettöl vezérelve követi el a büncselekményt.

\section{A vegyes motívum kérdésköre}

A szabályozási modellek kérdéskörétől elválaszthatatlan az elöítéletvezérelte büncselekményeket az „alapbüncselekményektöl” megkülönböztető tényállási elem, a motívum kérdése. A motívum értékelése ugyan javarészt jogalkalmazói kérdés, és nem is jellemző, hogy a büntető törvénykönyv definiálja a gyülölet- vagy elöítéletmotivációt, de a gyülölet-büncselekmények tényállásának alapvető elemét képezi az alapcselekmény mellett.

A bírák nem csupán az elkövető tudatától független objektív elemeket (például elkövetési magatartás, elkövetési tárgy, passzív alany, eredmény stb.) vizsgálják, hanem az elkövető tudatát körülíró szubjektív ismérveket is (például szándék és gondatlanság, illetve célzat és motívum). Amint erre a magyar büntetőjog általános részét feldolgozó tankönyvek is rámutatnak, ${ }^{158}$ a motívum olyan indok, amelyet a törvényi tényállás értékel, így például a sértett valamely nemzeti, etnikai, faji, vallási csoporthoz tartozása. A motívum és tévedés kapcsán ebben a körben érdemes rámutatni, hogy a motívum alapjául szolgáló tényekben való tévedés irreleváns. Éppen ezért a sértettnek nem kell az adott védett csoporthoz tartoznia; elég, ha az elkövető az adott csoporthoz tartozónak véli. Ugyanígy például egy emberölés esetén, ha az elkövető bosszúból lelövi szerelmi vetélytársa gyermekeit, de később kiderül, hogy féltékenysége alaptalan volt, attól még ugyanúgy aljas indokból elkövetett emberölés büntettéért felel, mintha a féltékenység alapos lett volna. ${ }^{159}$

${ }^{158}$ Lásd Hollán-Kis 2008, 154-156.

${ }^{159}$ BH. 1982. 74. 
Közelebbről megvizsgálva a motívum fogalmát, a magyar Legfelsőbb Bíróság rámutatott, hogy az indíték vagy motívum az a „,belső buzditás, hajtóerö, amely a személyt a cselekménynél irányítja, az az érzelmi vagy értelmi mozzanat, amely a konkrét cselekmény elkövetésére készteti. Az inditóok valójában a bünös szándékot kialakitó ok”. Ennek megfelelően a magyar joggyakorlat konzekvensen amellett foglal állást, hogy például emberölés esetén az elöítélet-motívum aljas indokból elkövetést képez.

Az aljas indokból elkövetés kapcsán pedig a magyar Legfelsőbb Bíróság rámutatott, hogy az

„, aljas indokból vagy célból elkövetett emberölésen az erkölcsileg elvetendö motívumból fakadó, valamint ilyen célból megvalósított cselekményeket kell érteni. [...] Amennyiben az aljas cél megállapítható, az magában foglalja az indok aljasságát is, ennél fogva a minösités kapcsán csupán az elöbbi körülményre kell hivatkozni”. 160

Erre tekintettel hozta meg döntését a Debreceni Törvényszék is, amelyben kétséget kizáróan megállapította, hogy a vádlott cselekménye aljas indokból, célból történt, tekintettel arra, hogy az ölési cselekményt a homoszexuális személyek iránti gyülölete motiválta, melyet az ölési cselekmény során általa tett nyilatkozat alátámaszt. ${ }^{161}$

A motívum bizonyítása korántsem egyszerü feladat, hiszen az elkövető tudattartalmára vonatkozó információkat kell feltárni. Mindazonáltal az előítélet motívum sokszor a „külvilágban” is megjelenik, mert az elkövető elöítélete jellemzően tartósan van jelen az életében. Így például olyan faktorok, mint szélsőséges csoporttagság, ilyen csoportok rendezvényei keretében elkövetés, különböző rasszista szimbólumok viselése stb. az eset összes körülményeivel egybevetve bizonyíthatják az előítélet motívumot. ${ }^{162}$ Amint arra a Miskolci Törvényszék is rámutatott ítéletében a motívum nem eseti jelleggel, „azaz csak a konkrét cselekvéskor, hanem állandó jelleggel van jelen az elkövetö tudatában, annak nézetrendszerében gyökerezik. Mindezek következtében a motívum feltárásakor nem mellözhető az elkövetö általános gondolkodásmódjának, mindennapi

\footnotetext{
160 3/2013. BJE határozat. www.kuria-birosag.hu/hu/joghat/32013-szamu-bje-hatarozat (2014. május 4.) ${ }^{161}$ A Háttér Társaság által kutatási célból átadott ügyek. Debreceni Törvényszék, 25.B.48/2013/23. sz. 162 Bővebben lásd IACP: Responding to Hate Crimes...
} 
életben tanúsitott magatartásának, elözetes kijelentéseinek, illetve a cselekménnyel érintett csoport egyéb tagjaihoz való viszonyulásának vizsgálata."163

Sok esetben találkozhatunk több, egymás mellett megjelenő motívummal egy-egy büncselekmény esetében. A vegyes motiváció kapcsán kérdésként merül fel, hogy több motivációs faktor esetében is lehetőség van-e a gyülölet-büncselekmény megállapítására. A joggyakorlat mind hazai, mind nemzetközi viszonylatban azt mutatja, hogy az elöítéletes motivációnak lényegesnek, avagy elsődlegesnek kell lennie az ilyen típusú büncselekmény megállapításához. Az előítéletes motiváció akkor tekinthető lényegesnek, ha arra a kérdésre, hogy a büncselekmény elkövetésére az áldozat adott csoporthoz tartozása hiányában is sor került volna, a válasz nemleges.

Az amerikai joggyakorlatból példa egy nagy sajtónyilvánosságot kapott eset, amely 1991-ben Atlantic Beach városában (New York államban) történt. A híradások szerint $^{164}$ a történet egyértelműen gyülöletvezérelte büncselekmény látszatát keltette. Eszerint egy fehér középiskolásban, Shannon Siegelben hirtelen indulatok támadtak, amikor meglátta, hogy egy afroamerikai fiú flörtöl egy fehér nővel egy évzáró buli alkalmával. Rasszista sértéseket követően Siegel rátámadt a sértette, verekedni kezdtek, amíg a jelenlévők le nem állították őket. Később ugyanazon az estén az elkövető négy barátjával baseballütőkkel támadt az afroamerikai fiúra. A bíróság előtt a motiváció nem volt teljesen egyértelmü. Kiderült, hogy az ügyben szereplö lány az elkövető volt barátnője, az elkövető és a sértett pedig barátok voltak. Az elkövető apja azt vallotta, hogy a fia barátainak háromnegyede fekete, akikkel baráti viccelődésként rendszeresen rasszista sértéseket mondtak egymásnak. Az esküdtek elutasították az elöítéletes motivációt, mert álláspontjuk szerint a bűncselekmény egyébként is megtörtént volna, tekintettel a féltékenységre és megsértett büszkeségre. ${ }^{165}$

A Miskolci Törvényszék ${ }^{166}$ egy 2014-es ítéletében részletesen kitért a vegyes motiváció kérdéskörére, és rámutatott, hogy az elöítéletes motiváció akkor állapítható meg, ,ha $a z$ elkövetöt a csoporthoz tartozó személy ellen tanúsított eröszakos magatartására nem a konkrét személlyel szembeni sérelme, hanem e személynek az adott csoporthoz való

${ }^{163}$ Fkf.1099/2013/10.

164 Erről lásd pl.,A Better Response to Hate Crimes” The New York Times June 8, 1991. www.nytimes.com/1991/06/08/opinion/a-better-response-to-hate-crimes.html (2014. október 2.)

${ }^{165}$ Franklin 2002, 5.

${ }^{166}$ A Társaság a Szabadságjogokért által rendelkezésemre bocsátott ügyek egyike. Miskolci Törvényszék, 14.Fkf.1099/2013/10. sz. 
tartozása miatti ellenséges érzület inditotta”. A bíróság kimondta, hogy a motívum lehet vagylagos is, azaz az ellenséges érzület mellett más körülmény is megjelenhet motivációként, de a cselekmény ,elsődleges vezérlö motívumának a közösséghez való tartozás miatti ellenséges érzületnek kell lennie. Ez a motívum pedig nem eseti jelleggel, hanem állandó jelleggel van jelen az elkövetö tudatában, annak nézetrendszerében gyökerezik”. A bíróság a bizonyítás kapcsán arra is rámutatott, hogy -- éppen a nézetrendszerben gyökerező ellenséges érzület miatt -- a motívum feltárása érdekében elengedhetetlen „az elkövetö általános gondolkodásmódjának, mindennapi életben tanúsitott magatartásának, elözetes kijelentéseinek, illetve a cselekménnyel érintett csoport egyéb tagjaihoz való viszonyulásának vizsgálata”. Ahogyan ezt tette a bíróság a fenti amerikai esetben is, hiszen az eljárás során részletesen feltárták az elkövető kapcsolatrendszerét, mindennapi életben tanúsított magatartását, és arra jutottak, hogy a baráti köre és nézetrendszere --valamint a büncselekmény elkövetésének egyéb körülményei -- alapján nem állapítható meg a rasszista motiváció elsődleges motivációként. Amint annak a Miskolci Törvényszék is hangot adott, több lehetséges motívum fennállása esetén kizárólag az elkövető személyiségének megismerését követően lehet megalapozottan állást foglalni azt illetően, hogy az elkövető erőszakos cselekményét ,,másnak valamely csoporthoz való tartozása miatti ellenséges érzülete vagy egy konkrét sérelem indította”. ${ }^{167} \mathrm{Ha}$ az erőszakos fellépés motívuma elsősorban egy konkrét sérelem (mint például a fenti esetben, ahol az elkövető szubjektíve sérelemnek élte meg, hogy a volt barátnőjét egy másik férfi társaságában találta), és a sértett adott csoporthoz való tartozásához kapcsolódóan elhangzott szidalmazás mintegy az indulat levezetésének tekinthető, úgy gyülöletvezérelte büncselekményről - a magyarországi szabályozás alapján „,közösség tagja elleni erőszak”-ról ${ }^{168}$ - álláspontom szerint nem beszélhetünk.

Hasonló következtetésre jutott az ügyészség egy 2012-es nyomozás felfüggesztése ellen bejelentett panasz elutasításáról szóló határozatában. ${ }^{169}$ Az ügyben két férfi a trolin hangoskodott, majd amikor a sértett többször is rájuk nézett, szidalmazni kezdték. A sértettel együtt a két ismeretlen személy is leszállt a jármüröl, majd a sértettet többször ököllel arcon ütötték, valamint rugdosták, miközben káromkodtak, és a sértett szexuális

\footnotetext{
167 Fkf.1099/2013/10.

168 Btk. 216. §.

${ }^{169}$ A Háttér Társaság a Melegekért által rendelkezésemre bocsátott ügyek egyike. Budapesti VI. és VII. kerületi Ügyészség, B. VI--VII. 3541/2012/2.
} 
irányultságára utaló kifejezéseket használtak. Az ügyészség határozatában rámutatott, hogy az „elkövetők által használt trágár kifejezések az ittas állapotban elkövetett, garázda jellegü, gátlástalan támadások során sajnálatos módon igen széles teret nyertek, elszaporodtak, azt agresszivan, kötekedöen fellépö elkövetök válogatás nélkül használják”. Azaz a homofób sértéseket a mindennapi káromkodás körébe tartozónak tekintette az ügyészség az ügy körülményeire tekintettel, illetve, a támadás elsődleges motivációjaként nem a sértett szexuális irányultságát azonosította.

\section{A védett csoportok köre}

A jogalkotónak amellett, hogy milyen formában szabályozza a gyülöletvezérelte büncselekményeket (sui generis tényállás, minősítő körülmény vagy büntetéskiszabási elvek körében), a védett csoportok köréről is döntést kell hoznia.

A védett csoportok meghatározása közel sem egyszerü kérdés, és az elöítéletvezérelte büncselekmények természetének, valamint az adott állam történelmi hagyományainak mélyebb vizsgálata nélkül nehezen eldönthető. Az elöítélet sok esetben társadalmi kontextusban is létezik, és nem feltétlenül az elkövető saját tapasztalatai és nézetei képezik az alapokat, hanem társadalmi szinten létező szemléletmód határozza meg az elkövetőnek a cselekménnyel érintett csoport tagjaival kapcsolatos nézetrendszerét. Így például, előfordulhat, hogy A már egy találkozás elött nem kedveli B-t zsidó származása miatt, mert A úgy gondolja, hogy a zsidók megbízhatatlanok, így B-ben sem lehet megbízni. Tehát, a feltételezés egy vallási csoporttal kapcsolatos, a társadalomban elterjedt sztereotípiára épül. ${ }^{170}$

\subsection{A szabályozás kisebbség- vagy identitásvédö intézkedés jellege}

A sértetti kör szabályozása kapcsán elsősorban arról kell dönteni, hogy mely tulajdonságokat kell egyáltalán fontolóra venni, illetve melyeket foglalja jogszabályba a jogalkotó. Alapvetően kétféle álláspont létezik a védett tulajdonságok meghatározására vonatkozóan. Az egyik nézet szerint a gyülölet-büncselekményekkel kapcsolatos szabályozás, úgymond, „kisebbségvédő intézkedés”, vagyis kifejezetten egy adott társadalomban hátrányos helyzetü, diszkriminált, nagyfokú előítéletességgel sújtott, avagy tradicionálisan elnyomott csoportokat véd, éppen e helyzet ellensúlyozása

${ }^{170}$ Lawrence 1999. 29-44. 
érdekében. ${ }^{171}$ Tehát a szabályozás a kiszolgáltatottságot igyekszik ellensúlyozni a speciális védelemmel.

Mindeközben, a másik álláspont szerint a fokozott büntetőjogi fellépés indoka kizárólag az elöítéletes motiváció, függetlenül attól, hogy a büncselekmény sérülékeny csoport ellen irányul vagy sem. Tehát a szabályozás egyfajta ,identitásvédő” funkciót tölt be ez esetben. ${ }^{172} \mathrm{Az}$ amerikai és magyar joggyakorlat is egyaránt ebbe az irányba mozdult el, ahogyan ezt például az amerikai legfelső bíróság Wisconsin kontra Mitchell ügye ${ }^{173}$ vagy a magyar Tavaszmező utcai ügy néven elhíresült -- és jogvédő szervezetek által sokat kritizált -- eset $^{174}$ szemlélteti.

A magyar Alkotmánybíróság egy a gyülöletbeszéddel kapcsolatos határozatában ${ }^{175}$ is rámutatott, hogy ha a jogalkotó csak a kisebbségekhez tartozó személyeket védi a gyülöletbeszéddel szemben, az sérti a megkülönböztetés tilalmát. Az Alkotmánybíróság gyakorlata alapján a megkülönböztetés tilalma arra vonatkozik, hogy a jognak mindenkit egyenlőként, egyenlő méltóságú személyként kell kezelnie. Alanyi jogok esetén a szabályozás a megkülönböztetés tilalmába ütközik, ha az adott szabályozási koncepción belül a homogén csoportba tartozókra vonatkozóan -- tárgyilagos mérlegelés szerinti ésszerű indok nélkül, azaz önkényesen -- eltérő szabályozást tartalmaz. Az ilyen szabályozás végső soron sérti az emberi méltósághoz füződő alapjogot, mert a jogalkotó nem kezeli az érintetteket azonos méltóságú személyként.

A 2008-as határozattal megvizsgált szabályozás alapját azt képezte volna, hogy elismerhetők-e olyan, a személyiségbe beépült tulajdonságok, amelyek egyben közösségteremtő funkcióval is rendelkeznek, azonban a szabályozás ez alapján a védelem körét leszükítette volna a kisebbséghez tartozó személyekre. A törvényjavaslat pontos szövege szerint:

\footnotetext{
${ }^{171}$ Átol Dorottya [et al.] 2013, 83.

172 Átol [et al.] 2013, 83.

173 1989. október 7-én éjjel fiatal fekete férfiak és fiúk egy lakásban gyültek össze Kenosha-ban (Wisconsin) és a Lángoló Mississippi címü film egy megrázó jelenetéről társalogtak, amelyben egy fehér férfi egy fekete fiút ütlegel imádkozás közben. Végül a beszélgetés hatására az utcára mentek, és megtámadták az első feléjük sétáló fehér fiút. Bővebben lásd www.law.cornell.edu/supct/html/92515.ZO.html (2014. május 7.)

${ }^{174}$ Egy nem roma fiatalembert a Budapest VIII. kerületi jórészt romák által lakott utcában romák támadtak meg, az ítéleti tényállás szerint káromkodó „magyarozás” közepette. „A Kúria valamennyi vádlottat magyarellenes erőszakért vonta felelősségre.” Lásd Jovánovics-Pap 2013, 155.

175 96/2008. (VII. 3.) AB határozat, ABH 2008, 831-832.
} 
„, a személyhez füződő jog sérelmét jelenti különösen az a sértö megnyilvánulás, amely faji hovatartozásra, nemzeti vagy etnikai kisebbséghez való tartozásra, vallási vagy világnézeti meggyőződésre, szexuális irányultságra, nemi identitásra vagy a személyiség más lényegi vonására irányul, és személyek e vonással rendelkezö, a társadalmon belül kisebbségben lévö körére vonatkozik." 176

Az indokolásban hangsúlyozták, hogy a törvényjavaslat nyílt végü taxációval határozza meg a védett tulajdonságokat, lehetőséget adva arra, hogy a bíróságok további tulajdonságokat is a személyiség lényegi vonásának minősítsenek.

Az Alkotmánybíróság álláspontja szerint viszont a fenti esetben nincs meg az ésszerü indoka annak, hogy a csoportképző tulajdonságok csak kisebbségi helyzetü személyösszességet jellemezhetnek. Ha a védelem tárgya olyan közösséget jellemző tulajdonság, amely a társadalom egészéhez viszonyított többséget jellemzi, a magukat a közösséghez tartozónak tekintő személyek -- csupán számbeli többségükre tekintettel -védelem nélkül maradnának. Ez pedig azt jelentené, hogy „, a szabályozás nem kezeli az érintetteket egyenlö méltóságú személyként, ugyanakkor az eltérö kezelésnek nincs a tárgyilagos mérlegelés szerint ésszerü indoka". 177

Kérdéses, hogy az Alkotmánybíróság fenti döntése helytálló-e a gyülöletbüncselekmények kapcsán is. Azaz a testület döntése irányadó-e, amikor arról kell dönteni, hogy például beszélhetünk-e „magyarellenes” büncselekményekről Magyarországon, amely kérdés például a Tavaszmező utcai és a Miskolci ítélet kapcsán is felmerült.

Az Alkotmánybíróság álláspontom szerint lényegében csupán a többség-kisebbség mint szükítő feltétel alkalmazásának tárgyilagos mérlegelés szerinti ésszerü indokot nélkülöző voltára mutatott rá: arra, hogy a „kisebbségben lévők köre” mint számszerü szükítés nélkülözi az ésszerü indokokat. A törvényjavaslat szövege egyértelmüen felsorolja azon védett csoportokat, amelyekkel kapcsolatban az Alkotmánybíróság korábbi gyakorlata során már megállapította, hogy a vallási és más világnézeti meggyőződést, illetve a nemzeti vagy etnikai hovatartozást a személyiség lényegi

176 96/2008. (VII. 3.) AB határozat, ABH 2008, 818-819.

177 96/2008. (VII. 3.) AB határozat, ABH 2008, 832. 
vonásának tekinti, a Legfelsőbb Bíróság pedig az EBH 2005. 1216. számú határozatában a szexuális irányultságot is e körbe tartozónak minősítette. Az Alkotmánybíróság a fenti döntésében nem utal arra, hogy magát a személyiség lényegi vonása alapján történő csoportképzést tekintené alkotmányellenesnek, hanem csak az utolsó fordulatról, azaz „, a társadalmon belül kisebbségben lévők körére” szükítésről szólt, amely a társadalmon belüli számbeli arányokat tekintve utal a kisebbségekre. Az Alkotmánybíróság megállapítása ilyen formában pedig határozottan ésszerünek tűnik, hiszen a múlt eseményei bebizonyították már, hogy egy számbeli kisebbség is megszerezheti a hatalmat, és veszélyt jelenthet a többség számára, ahogyan ez DélAfrikában is történt. ${ }^{178}$

Trócsányi László alkotmánybíró maga is rámutatott párhuzamos indokolásában, hogy az Alkotmánybíróság korábban két olyan tulajdonságot nevezett meg, amelyek egyrészt a teljes személyiséget meghatározzák, másrészt csoportképző tulajdonságok. Ez a két tulajdonság a vallási meggyőződés és a nemzeti vagy etnikai kisebbséghez tartozás. Érvelése szerint ezek mellett természetesen létezhetnek más releváns csoportképző tulajdonságok is.

„Ha a csoport éppen abból képzödik, hogy tagjainak valamilyen objektív, netán külsöleg is megnyilvánuló, vagy természetadta, levetközhetetlen, de legalábbis semmiképpen sem társadalmi funkcióját, szociális szerepét érintö olyan tulajdonsága van, amely másoktól megkülönbözteti; továbbá a sértés éppen ezt a csoportképzö tulajdonságot veszi célba, akkor föltehetjük, hogy a csoportot ért sértés eleve az alacsonyabb rendüséget fejezheti ki csak, vagy az önazonosság megkérdőjelezésére irányul. [...] A bíróságok és végső soron a Legfelsőbb Bíróság feladata, hogy a kollektív defamáció jogvédelmi tesztjét/az átsugárzás intenzitásával kapcsolatos szempontokat az esetjog kialakítása során meghatározzák. Ennek keretében a joggyakorlat meghatározhat olyan szempontokat, mint pl. a) a konkrét jogsértésnek az egyén élethelyzetét alapvetöen meghatározó közösséget kell érnie, amely közösséghez tartozásnak a megszüntetése a közösség tagja számára nem lehetséges, vagy az emberi méltóságának feladásával (önfeladással),

\footnotetext{
${ }^{178} \mathrm{~A} \quad$ dél-afrikai apartheidre lásd pl. gepeskonyv.btk.elte.hu/adatok/Tortenelem/AfrikanisztikaMA/b\%FArg\%E1bor/21.b\%FAr.Apartheid.pdf (2014. május 14.)
} 
illetöleg jelentös sérelmével járna; b) a társadalom értékitélete szerint a konkrét sérelem alkalmas-e arra, hogy a sérelemmel célzott közösség tagjaiban a jogsérelem ismételt bekövetkezése miatti félelmet keltsen. "179

A hivatkozott párhuzamos indokolás is azt a szemléletmódot tükrözi, amely szerint egy csoport megsértése elnyomó hatású lehet, az alacsonyabbrendűség érzékeltetésére szolgálhat, illetve a csoport tagjait identitásérzetükben sértheti -- ami újra visszavezet az eredeti dilemmához: azaz, hogy 'kisebbségvédő' vagy 'identitásvédő' szabályozásként tekinthetünk a gyülölet-büncselekményekkel kapcsolatos jogszabályokra. Figyelembe véve az Alkotmánybíróságnak a pozitív diszkrimináció területén kialakult gyakorlatát, amely szerint „a diszkrimináció tilalma nem jelenti azt, hogy minden, még a végsö soron nagyobb társadalmi egyenlöséget célzó megkülönböztetés is tilos , ${ }^{180}$ felveti annak kérdését, hogy az Alkotmánybíróság vajon a 'kisebbségvédő' vagy 'identitásvédő' funkció mellett foglalna-e állást.

„A megkülönböztetés tilalma arra vonatkozik, hogy a jognak mindenkit egyenlöként (egyenlö méltóságú személyként) kell kezelnie, azaz az emberi méltóság alapjogán nem eshet csorba, azonos tisztelettel és körültekintéssel, az egyéni szempontok azonos mértékü figyelembevételével kell a jogosultságok és a kedvezmények elosztásának szempontjait meghatározni.",181

Az Alkotmánybíróság emellett megállapította, hogy:

„, az azonos személyi méltóság jogából esetenként következhet olyan jog is, hogy a javakat és esélyeket mindenki számára (mennyiségileg is) egyenlöen osszák el. De ha valamely -- az Alkotmányba nem ütközö -- társadalmi cél, vagy valamely alkotmányos jog csakis úgy érvényesithetö, hogy e szükebb értelemben vett egyenlöség nem valósitható meg, akkor az ilyen pozitív diszkriminációt nem lehet alkotmányellenesnek minösíteni. A pozitív diszkrimináció korlátjának a tágabb értelemben leirt, tehát az egyenlö méltóságra vonatkozó megkülönböztetés tilalma, illetve az Alkotmányban pozitívan megfogalmazott alapjogok tekintendök. Bár a társadalmi

\footnotetext{
179 96/2008. (VII. 3.) AB határozat, ABH 2008, 836-837.

180 9/1990. (IV. 25.) AB határozat, ABH 1990, 48.

181 9/1990. (IV. 25.) AB határozat, ABH 1990, 46, 48.
} 
egyenlöség mint cél, mint társadalmi érdek, megelőzhet egyéni érdekeket, de nem kerülhet az egyén alkotmányos jogai elé." 182

Kérdés tehát, hogy jelen esetben vajon tárgyilagos mérlegelés szerinti ésszerü indokot képezhetne-e, ha a kisebbségekre szükítené le a jogalkotó a gyülölet-büncselekmények szabályozását; de nem a számszerü kisebbség értelmében, hanem a sérülékenység, a hátrányos helyzet, a történelmi tapasztalatok, a stigmatizáltság, a jelenkori társadalom előítéletessége, valamin a rendszerszintű diszkrimináció fogalmi síkjain értelmezve. Egy ilyen álláspont esetén pedig a nemzeti többséghez, a magyar nemzethez való tartozást Magyarországon nem lehetne a személyiség olyan elemének tekinteni, amely stigmatizáltságot, kiszolgáltatottságot, fenyegetettséget hordozna, és ezáltal a kiemelt büntetőjogi védelemre igényt tarthatna. ${ }^{183}$

Álláspontom szerint azáltal, hogy az Alkotmánybíróság a számszerüséget tekintve alkotmányellenesnek nyilvánította a szükítést, nem foglalt egyben állást a fenti érvek alapján történő szükítés alkotmányellenessége mellett is. Emellett a testület a gyülöletbeszéd vonatkozásában hozott döntést, és nem a közösség tagja elleni erőszak (gyülölet-büncselekmény) vonatkozásában, amelynek alapcselekménye mindenkor büncselekmény.

\subsection{A védett csoportok szabályozásának módszerei - Nyílt vagy zárt végü lista}

Ami a sértetti kör szabályozásának módszerét illeti, a jogalkotó számára két lehetőség kínálkozik, nevezetesen dönthet a nyílt vagy a zárt végü lista alkalmazása mellett. Nyílt listát alkalmaz a jogalkotó, amikor nem (csupán) taxatív listát ad a védett tulajdonságokról, hanem az általában leggyakoribb tulajdonságok mellé beiktat egy általános kategóriát, amelynek tartalommal megtöltését a jogalkalmazóra bízza. Ilyen például a magyar szabályozás, amely a nemzeti, etnikai, faji és vallási csoportok mellett a „lakosság egyes csoportjaihoz tartozás” kitételt tartalmazza, amelyet tovább részletez azzal, hogy ilyen különösen a fogyatékosság, a nemi identitás és a szexuális irányultság. ${ }^{184}$ Nyílt listát tartalmaz például a finn büntető törvénykönyv is, amely a büntetés kiszabásról szóló rendelkezések között általános minősítő körülményként szabályozza az előítéletes motivációt, és a faj, bőrszín, születési helyzet, nemzeti vagy

\footnotetext{
182 9/1990. (IV.25.) AB határozat, ABH 1991, 47-48.

${ }^{183}$ Ez az álláspont jelenik meg a védendő csoportokkal kapcsolatban pl. Jovánovics-Pap 2013, 156.

${ }^{184}$ Btk. 216. §.
} 
etnikai hovatartozás, vallás vagy meggyőződés, szexuális irányultság és fogyatékosság mellett nyitva hagyja a jogalkalmazó számára a védett tulajdonságok körét a más hasonló ok kitétellel. ${ }^{185}$

A nyílt végü lista azonban túl tágra szabja a védett csoportok körét, és olyan csoportok is védelmet kaphatnak, amelyek nem érdemelnek speciális védelmet, azaz túl tág jogértelmezésre ad lehetőséget, és jogbizonytalanságot okoz, ezzel nehezítve a hatékony jogalkalmazást. ${ }^{186}$ Ezáltal pedig lényegében kiüresítik a gyülölet-büncselekményekkel kapcsolatos szabályozást, mivel az elveszti eredeti szimbolikus funkcióját.

Ez a káros hatás kiküszöbölhető a védett tulajdonságok körének pontos meghatározásával, azaz a zárt végü lista alkalmazásával. A védett csoportok zárt végü listájának alkalmazását ajánlja az EBESZ is, arra hivatkozva, hogy a nyílt végü lista jogalkalmazási bizonytalanságot teremthet, amellyel végeredményben szubjektív értékelésre és önkényes döntésre bízza a jogalkotó, hogy mely csoportokat illeti meg a gyülölet-büncselekményekkel szembeni speciális védelem. Ezzel szemben, ha túl szük listát hoz létre a jogalkotó, akkor növeli a kockázatát, hogy olyan csoportokat rekeszt ki, amelyek gyakran válnak gyülöletvezérelt büncselekmény áldozatává. ${ }^{187}$

Tehát a jogalkotónak gondosan mérlegelnie kell, hogy mely csoportokat részesít védelemben. ${ }^{188}$ A különböző történelmi tapasztalatok, az adott állam társadalmi berendezkedésének sajátosságai eltérő listák megalkotásához vezetnek, de vannak klasszikus kategóriák: faj, bőrszín, nemzeti vagy etnikai hovatartozás, vallás, szexuális irányultság, nem, fogyatékosság. Az amerikai tapasztalatok a rabszolgaság és az afroamerikai csoportok elnyomása kapcsán értelemszerüen indokolták a faj mint védett kategória beiktatását -- míg Európában a romák üldöztetése, valamint napjainkban a muzulmánokkal és bevándorlókkal szembeni támadások megnövekedett száma egyértelmüen indokolja e csoportok védelemben részesítését. ${ }^{189} \mathrm{Az}$ EBESZ negyvenhárom tagállama által biztosított adatok alapján az alábbiak szerint alakulnak a védett csoportok: az etnikai vagy nemzeti hovatartozás harmincöt; a vallás harmincöt;

\footnotetext{
${ }^{185}$ Lásd The Criminal Code of Finland. www.finlex.fi/en/laki/kaannokset/1889/en18890039.pdf. ${ }^{186}$ Lásd bővebben Bárd Petra: „Gyülölt csoportok” http://szuveren.hu/jog/gyulolt-csoportok (2014. május 10.), ill. GYEM: Javaslatok az új Büntetö Törvénykönyv gyülölet-büncselekményekre vonatkozó szabályozására, 2012, 3.

${ }^{187}$ EBESZ/DIEJH 2009, 39.

${ }^{188}$ Lásd Pap 2013, 115-155.

${ }^{189}$ Lásd Pap 2013, 140.
} 
faj, illetve bőrszín harmincnégy; szexuális irányultság húsz; állampolgárság tizennyolc; nem tizenöt; nyelv tizenhárom; fogyatékosság tizenhárom; nemi identitás kilenc; egyéb kategória tizenöt tagállam szabályozásában szerepel. ${ }^{190}$

\subsection{A ,faj” mint védett kategória}

A faj mint védett kategória kapcsán le kell szögezni, hogy a faj fogalma a nemzetközi és nemzeti dokumentumokban kizárólag társadalmi konstrukcióként jelenik meg, mivel a különböző emberi „fajok” létére alapozott, biologizáló elméletek egyértelmüen elutasítandók. A faj fogalmát leginkább azért használja számos dokumentum a mai napig, hogy azok a személyek, akiket ,egy másik fajhoz” tartozónak tekintenek, a jogszabályok által biztosított védelemből semmiképp ne legyenek kizárva. Az UNESCO $^{191}$ állásfoglalása ${ }^{192}$ alapján az emberi faj esetében kerülendő lenne a „faj” terminus használata, és inkább az etnikai csoport megnevezés lenne javasolt. Mindazonáltal tagadhatatlan, hogy az angol „faj” kifejezéshez ('race') szorosan kapcsolódó fogalmak, mint a rasszizmus ('racism') és rasszista/faji diszkrimináció ('racial discrimination') aligha helyettesíthetőek olyan más kifejezéssel, amely ilyen átfogóan egyesítené az etnikai diszkrimináció valamennyi megnyilvánulási formáját. A faji megkülönböztetés valamennyi formájának kiküszöböléséről szóló nemzetközi egyezmény ${ }^{193}$ 1. cikke által meghatározott fogalom jól szemlélteti a faji megkülönböztetés fent említett komplexitását. Az egyezmény szerint faji megkülönböztetés minden olyan

„,különbségtételt, kizárást, megszoritást vagy elönyben részesitést jelent, amelynek alapja a faj, a szín, a leszármazás, a nemzetiségi vagy etnikai származás, és amelynek célja vagy eredménye politikai, gazdasági, társadalmi, kulturális téren vagy a közélet bármely más terén az emberi jogok és alapvetö szabadságjogok elismerésének, egyenrangú élvezetének vagy gyakorlásának megsemmisítése vagy csorbitása”.

\footnotetext{
${ }^{190}$ EBESZ/DIEJH: Hate Crimes in the OSCE Region - Incidents and Responses, Annual Report for 2010, 2010, 18. tandis.odihr.pl/hcr2010/pdf/Hate_Crime_Report_full_version.pdf (2014. március 7.)

${ }^{191}$ United Nations Educational, Scientific and Cultural Organization, UNESCO. en.unesco.org.

192 UNESCO: Four Statements on the Race Questions, 1969. unesdoc.unesco.org/images/0012/001229/122962eo.pdf (2014. szeptember 3.)

${ }^{193}$ Nemzetközi egyezmény a faji megkülönböztetés valamennyi formájának kiküszöböléséröl. Kihirdette az 1969. évi 8. törvényerejü rendelet a faji megkülönböztetés valamennyi formájának kiküszöböléséröl New Yorkban 1965. december 21 -én elfogadott nemzetközi egyezmény kihirdetéséről.
} 
Az Európa Tanács Rasszizmus és Intolerancia elleni Bizottságának ${ }^{194}$ 7. számú ajánlása ${ }^{195}$ által meghatározott rasszizmus azt a

„,meggyözödést jelenti, amely szerint a faj, a börszín, a nyelv, a vallás, az állampolgárság vagy a nemzeti vagy etnikai származás igazolja valamely személynek vagy személyek valamely csoportjának a lealacsonyítását, vagy valamely személynek vagy személyek valamely csoportjának a felsőbbrendüségét”.

Ez utóbbi meghatározás is magában foglalja a gyülölet-büncselekmények szabályozásában leggyakrabban megjelenő védett csoportokat; jelen írás a rasszizmus terminust ebben az átfogó jelentéstartalmában használja.

\subsection{A nemzeti vagy etnikai származás/etnicitás}

A nemzeti vagy etnikai származás/etnicitás fogalmak jelentéstartalma szintén függ az adott társadalmi környezettől, és sokszor egymást átfedő kategóriákról beszélhetünk. ${ }^{196}$ Az ,etnikai csoport” fogalmának nincs pontos, általánosan elfogadott szociológiai meghatározása. Az egyes definíciók közös és meghatározó eleme a közös eredet, hagyományok, múlt, illetve a kultúra, valamint a csoportidentitást olyan meghatározó szimbolikus elemeire fókuszálnak, mint a származás, vallás, nyelv, származási ország, külső megjelenés. ${ }^{197}$ A nemzetfogalom kapcsán az Európa Tanács Parlamenti Közgyülése 1735. (2006.) számú ajánlásában ${ }^{198}$-- harmincöt ország parlamenti delegációja által kitöltött kérdöív adatain, valamint jog- és politikatudományi szakértők véleményei alapján -- megállapította, hogy csaknem lehetetlen a nemzet fogalmának általános definícióját kialakítani. A nemzet kifejezés mélyen a népek kultúrájában és történelmében gyökerezik. Egyaránt jelölhet állampolgárságot vagy olyan szerves

\footnotetext{
194 European Commission against Racism and Intolerance, ECRI. www.coe.int/t/dghl/monitoring/ecri/default_en.asp.

195 ECRI 7. sz. általános ajánlása: A rasszizmus és a faji megkülönböztetés elleni küzdelem a nemzeti jogalkotásban (ECRI General Policy Recommendation No. 7: National Legislation to Combat Racism and Racial Discrimination) CRI(2003) 08, 13 December 2002. www.europatanacs.hu/pdf/ECRI_7.pdf (2014. február 19.)

${ }^{196}$ Lásd pl. Pap 2013, 130-155.

${ }^{197}$ ECRI: „Ethnic” statistics and data protection in the Council of Europe countries, Study Report by $\begin{array}{llll}\text { Patrick Simon, } & \text { Strasbourg, } & 27 .\end{array}$ www.coe.int/t/dghl/monitoring/ecri/activities/themes/Ethnic_statistics_and_data_protection.pdf (2014. február 19.)

${ }^{198} \mathrm{Az}$ Európa Tanács Parlamenti Közgyülése 1735 (2006) sz. ajánlása, A nemzet fogalma, 2. www.mtaki.hu/data/files/208.pdf (2014. április 29.)
} 
közösséget, amely közös nyelvet beszél, közös kulturális hagyomány, közös múltértelmezés, illetve közös törekvések és jövőkép jellemzi. Az állampolgárság azonban megkülönböztetendő az etnikai hovatartozástól, hiszen mindig valamely magánszemély és valamely állam közötti jogi kapcsolatot jelent, amint azt az állampolgárságról szóló Európai Egyezmény is tartalmazza, az állampolgárság „valamely személy és egy állam közötti jogi kötelék, és nem utal a személy etnikai származására”. 199

\subsection{A vallás mint a védelem alapja}

A vallás mint védett kategória esetében a gyülölet-büncselekményekkel kapcsolatos jogszabályok nem meghatározott vallásokat védenek, függetlenül attól, hogy jogilag elismert egyházhoz kötődik-e. Némely szabályozás az értelmező rendelkezések között meghatározza, hogy a „vallás” fogalma magában foglalja a vallási nézetek követésének hiányát is. Belgiumban például a vallás kifejezés a vallásos és filozófiai meggyőződés valamennyi formájára vonatkozik, amely egy isten/istenek létezéséhez vagy nemlétezéséhez kötődik; a máltai büntető törvénykönyv alapján pedig vallási csoportot megillető védelem jár a vallási meggyőződés megléte és a vallási meggyőződés hiánya esetén is. $^{200}$

\subsection{Fogyatékosság mint védett tulajdonság}

További gyakori védett tulajdonság még a fogyatékosság, a szexuális irányultság és a nemi identitás. A fogyatékossággal élő személyek jogairól szóló egyezmény ${ }^{201} 1$. cikke alapján fogyatékossággal élő személy ,,minden olyan személy, aki hosszan tartó fizikai, értelmi, szellemi vagy érzékszervi károsodással él, amely számos egyéb akadállyal együtt korlátozhatja az adott személy teljes, hatékony és másokkal egyenlö társadalmi szerepvállalását”.

\footnotetext{
${ }^{199} \mathrm{Az}$ Európa Tanács keretében, 1997. november 6-án kelt, az állampolgárságról szóló Európai Egyezmény kihirdetéséröl szóló 2002 évi www.complex.hu/kzldat/t0200003.htm/t0200003.htm (2014. május 8.) ${ }^{200}$ EBESZ/DIEJH 2009, 43.

${ }^{201}$ A fogyatékossággal élő személyek jogairól szóló egyezmény. Kihirdette: a Fogyatékossággal élő személyek jogairól szóló egyezmény és az ahhoz kapcsolódó Fakultatív Jegyzőkönyv kihirdetéséről szóló 2007. évi XCII. tv.
} 


\subsection{Szexuális irányultság és nemi identitás}

A szexuális irányultság alatt az egyén azon képességét értjük, hogy azonos nemü vagy más nemü, vagy bármely nemü személyek iránt képes mély érzelmi és szexuális vonzalmat érezni, illetve velük intim és szexuális kapcsolatot kialakítani. ${ }^{202}$ Ez alapján beszélhetünk homo-, hetero-, illetve biszexuális szexuális irányultságról. A nemi identitás alatt minden ember mélyen és egyedi módon megélt társadalmi nemét értjük, amely megegyezhet a személynek születéskor tulajdonított biológiai nemmel, vagy eltérhet attól, és amelybe beletartozik az egyén személyes testérzete (amelyhez kapcsolódhat a testi megjelenés vagy müködés saját szándékból történő megváltoztatása orvosi-mütéti vagy egyéb úton) és a társadalmi nem egyéb kifejezési eszközei, mint például az öltözködés, a beszédstílus vagy a gesztusok. ${ }^{203}$ A biológiai nemüktől eltérő nemi azonosságtudattal rendelkező személyek átfogó megnevezésére a transznemü kifejezést használjuk. Azokra a személyekre, akik biológiai nemükkel ellentétes nemüként azonosulnak, és testüket ennek megfelelően kívánják átalakítani, a transzszexuális kifejezést használjuk. Arra a személyre, aki veleszületett biológiai adottságait tekintve férfi és női jellemzőkkel egyaránt rendelkezik, az interszexuális kifejezést használjuk. ${ }^{204}$

A jogalkotónak tehát két alapvető kérdésben kell döntenie a gyülöletvezérelte büncselekmények kapcsán, ha a szabályozás megalkotása mellett határoz. Először is azt kell meghatározni, hogy milyen formában szabályozza a gyülölet-büncselekményeket: külön tényállást hoz-e létre; minősítő körülményként; általános részi büntetési tételt emelő rendelkezésként; vagy súlyosító körülményként szabályozza az elöítéletmotivációt. A második lényeges kérdés, hogy a gyülölet-büncselekményekkel kapcsolatos jogszabályok kikre alkalmazandók, azaz a jogalkotó miként határozza meg a védett csoportokat, mely sértetti körre terjedjen ki a szabályozás.

A gyülölet-büncselekményekkel szembeni fellépés terén egészen eltérő megoldások alakultak ki a szabályozást illetően. A fent vázolt kritikák és bizonytalanságok ellenére számos ország úgy ítélte meg, hogy szükség van kiemelt figyelemre és súlyosabb

\footnotetext{
${ }^{202}$ Háttér Társaság, YogYakarta alapelvek: Alapelvek a nemzetközi emberi jogi szabályok alkalmazásáról a szexuális irányultsággal és a nemi identitással kapcsolatban, 2010. november $8 . \quad 8$. ypinaction.org/files/03/30/yogyakarta_hungarian.pdf (2014. május 5.)

${ }^{203}$ Lásd YogYakarta alapelvek, 8.

${ }^{204}$ Átol [et al.] 2013, 85.
} 
büntetésre a gyülölet-büncselekmények kapcsán, és meg is teremtették az ehhez szükséges szabályozás alapjait. A különböző jogalkotási modellek mindegyikére, illetve vegyes rendszerekre is találunk példákat. Így például az Egyesült Királyság a vegyes modellt követi; Németországban semmilyen szinten nincs külön gyülöletbüncselekményekkel kapcsolatos szabályozás, az elöítéletes motivációt a bírák a büntetés kiszabása során veszik figyelembe. ${ }^{205}$

A magyar gyülölet-büncselekményekkel kapcsolatos szabályozásban külön tényállás szerepel az elöítéletvezérelte büncselekményekre nézve, amely a garázda jellegü magatartásokat és a testi sértést foglalja magában (Btk. 216. §, közösség tagja elleni erőszak). Ezen kívül a Btk. nem tartalmaz közvetlenül más rendelkezést a gyülöletvezérelte büncselekményekre vonatkozóan. Minősített körülményként az elöítélet motiváció önmagában nem szerepel, de vannak olyan büncselekmények, amelyek minősített körülményként tartalmazzák az aljas indokból elkövetést. Bizonyos szempontból a népirtás (Btk. 142. §) és az apartheid (Btk. 144. §) tényállását is a gyülölet-büncselekményekkel kapcsolatos rendelkezések körébe sorolhatjuk, de ezek nem képezik jelen írás fókuszát. ${ }^{206}$ Végül vannak olyan bűncselekmények, amelyek önmagában a gyülölet kifejeződését büntetik, így azokat legfeljebb a gyülöletbüncselekmények speciális típusának tekinthetjük, így nem is képezik jelen írás és a kutatás fókuszát. Ide tartozik például a gyülöletbeszéd (közösség elleni uszítás), valamint a gyülöletbeszéd ilyen jellegű sajátosságát osztó tényállások: ${ }^{207}$ közösség elleni uszítás (Btk. 332. §); a nemzetiszocialista vagy kommunista rendszer büneinek nyilvános tagadása (Btk. 333. §); nemzeti jelkép megsértése (Btk. 334. §); önkényuralmi jelkép használata (Btk. 335. §). Álláspontom szerint a vegyes rendszer alkalmazásával, például az Egyesült Királyság mintájára, megszüntethetőek lennének a jelenlegi jogszabályi hiányosságok és a részben azokból fakadó jogalkalmazási problémák.

\footnotetext{
205 Bővebben lásd Human Rights Watch: „The State Response to »Hate Crimes« in Germany”Human Rights Watch Briefing Paper, 2011. http://www.hrw.org/news/2011/12/09/state-response-hate-crimesgermany (2014. november 5.)

${ }^{206}$ Ugyan szintén a közösségek védelmét hivatottak szolgálni, de olyan speciális jellemzőkkel bírnak, amelyek jelentős mértékben megkülönböztetik azokat a Btk.-ban szabályozott másbüncselekményektől.

207 A gyülöletbeszédet ilyen szempontból szintén tágan értelmezi Koltay András, és a kategóriához tartozónak tartja a nemzeti és önkényuralmi jelképekkel, valamint a holokauszttagadással kapcsolatos kérdéseket. Lásd Koltay 2013, 17.
} 
A védett csoportok kialakítását illetően kiemelten igaz az az állítás, hogy egy jogszabály akkor válhat a leghatékonyabbá és egyben kikényszeríthetővé, ha figyelemmel van az adott ország történelmi tapasztalataira, társadalmi berendezkedésére. Amint arra Koltay András is rámutat ${ }^{208}$ a gyülöletbeszéd kapcsán, a szabályozás jelentős részben függ az adott ország társadalmi, kulturális állapotától és közelmúltbeli történelmétől. A gyülölködés kérdésére adott jogalkotói válaszoknak igazodnia a társadalmi realitásokhoz, és az átültetett jogi szabályoknak beilleszthetőnek kell lenniük a jogrendszer egyéb szabályi közé. Ha a jogalkotó elmulasztja ezeket a körülményeket figyelembe venni, valamint adott esetben a jogalkalmazók is ezen az úton maradnak, és kiterjesztik a gyülölet-büncselekmények által biztosított védelmet társadalmi csoportok már-már korlátlan körére, akkor az a gyülölet-büncselekményekkel kapcsolatos szabályozás teljes kiüresedéséhez vezethet, és az eredetileg biztosítani kívánt társadalomnevelö,-felvilágosító, állami és társadalmi szolidaritást kifejező, a társadalomban meglévő egyenlőtlenségeket mérséklő és társadalmi feszültséget csökkentő funkciói elenyésznek.

A szabályozási modell és a védett csoportok meghatározása mellett persze egyéb kérdéseket is jogszabályba fektethet a jogalkotó: így a gyülöletvezéreltség mint motívum meghatározását; az elkövetői tévedés tényállásban értékelését; illetve a bizonyítottság szempontjainak meghatározását ${ }^{209}$ is - annak ellenére, hogy ezek nem szükségszerüen jogalkotási kérdések. A motívum értékelése javarészt jogalkalmazói kérdés és nem is jellemzö, hogy a büntető törvénykönyv definiálja a gyülölet- vagy elöítélet-motivációt. A bizonyítottság kérdésköre komplexitásából és eljárásjogi jellegéből adódóan szintén inkább a jogalkalmazásra tartozó kérdéskör, így például nyomozati protokollokban emelendőek ki azok a faktorok, amelyek a gyülöletbüncselekmény gyanúját támasztják alá. Így álláspontom szerint a fenti két kérdéskör képezi azt a minimumot, amelyben a jogalkotónak szükségszerüen állást kell foglalnia a szabályozás kialakítása során.

${ }^{208}$ Koltay András: „A gyülöletbeszéd korlátozásának elméleti szempontjai” Iustum aequum salutare, 2011/3. 111-124.

${ }^{209}$ Novoszádek Nóra-Rácz Dominika: „Gyülöletvezérelt büncselekmények európai szabályozási mintái"Föld-rész, 2009/3--4. 63-80. 


\section{Magyarország nemzetközi jogi és európai uniós kötelezettségei a gyülölet-büncselekményekkel szembeni fellépésre vonatkozóan}

Számos nemzetközi dokumentum tartalmaz általános szabályokat a diszkrimináció tilalma kapcsán, illetve foglalkozik a gyülölet-büncselekmények definiálásával, felszámolásával és egyéb kapcsolódó kérdéskörökkel, így a megkülönböztetett figyelem és a kiemelt büntetőjogi védelem bizonyos szempontok tekintetében a nemzetközi kötelezettségekből is fakad. Jelen fejezet a továbbiakban elsősorban azokkal a Magyarország szempontjából jelentőséggel bíró - fontosabb nemzetközi emberi jogi dokumentumokkal és közösségi jogi szabályokkal foglalkozik, amelyek a diszkrimináció különböző formáinak tilalmához és gyülölet-büncselekményekhez kapcsolódnak. Így többek között az ENSZ és az Európa Tanács keretében elfogadott nemzetközi emberi jogi szerződéseket veszi sorra, amelyek, miután belső jogszabályokkal kihirdették őket, segítségül hívhatók, azaz hivatkozási alapul szolgálhatnak a gyülölet-büncselekményekkel szembeni küzdelemben, valamint azon elsődleges és másodlagos közösségi jogi forrásokat ismerteti, amelyek a diszkrimináció és gyülölet motiválta cselekmények elleni küzdelem terén fontos kiindulópontot jelentenek.

\section{Egyesült Nemzetek Szervezete}

A Polgári és Politikai Jogok Nemzetközi Egyezségokmányának ${ }^{210}$ részes államként - a 2. cikk 1. pont alapján - Magyarország kötelezi magát, hogy az Egyezségokmányban elismert jogokat minden megkülönböztetés, így különösen ,faj, szín, nem, nyelv, vallás, politikai vagy más vélemény, nemzeti vagy társadalmi származás, vagyoni, születési, vagy egyéb helyzet szerinti különbségtétel nélkül' biztosítja. Emellett a 26. cikk kimondja a diszkrimináció tilalmát, amely értelmében , ,a törvény elött minden személy egyenlö és minden megkülönböztetés nélkül joga van egyenlö törvényes védelemre", és „erre tekintettel a törvénynek minden megkülönböztetést tiltania kell és minden személy számára egyenlö és hatékony védelmet kell biztositania bármilyen megkülönböztetés ellen, mint amilyen például a faj, szín, nem, nyelv, vallás, politikai vagy egyéb

${ }^{210}$ Polgári és Politikai Jogok Nemzetközi Egyezségokmánya (International Covenant on Civil and Political Rights) U.N.T.S. No. 14668, Vol. 999, 1966, 172. (Magyarországon kihirdette az 1976. évi 8. törvényerejü rendelet.) 
vélemény, nemzeti vagy társadalmi származás, vagyoni, születési vagy más helyzet alapján történö megkülönböztetés". A cikk ugyan nem említi például a szexuális irányultságot, nemi identitást, de - az egyezségokmány végrehajtásának ellenőrzését végző - Emberi Jogi Bizottság ${ }^{211}$ számos esetben kinyilvánította, ${ }^{212}$ hogy a szexuális irányultság is egy olyan tényező, amelyre kiterjed az Egyezségokmány által biztosított védelem. A Bizottság például Lengyelország jelentése kapcsán kiemelte, hogy az új alkotmányból a diszkrimináció tilalmát megfogalmazó rendelkezésből - a tervezettől eltérően - kimaradt a szexuális irányultság mint védett tulajdonság, és ez az Egyezségokmány 17. és 26. cikkének sérelmével járhat. ${ }^{213}$ Emellett az ENSZ Emberi Jogi Tanácsának az emberi jogokról, szexuális irányultságról és nemi identitásról szóló határozata ${ }^{214} \mathrm{az}$ első olyan ENSZ-határozat, amely külön a szexuális irányultsággal és nemi identitással foglalkozik. Ugyanezen évben az ENSZ Emberi Jogi Főbiztosa ${ }^{215}$ jelentést készített az egyének szexuális irányultságán és nemi identitásán alapuló diszkriminatív törvényekről, gyakorlatokról és erőszakos cselekményekről, ${ }^{216}$ amelyben rámutatott a gyülölet-büncselekmények egyes sajátosságaira, például a homofób büncselekmények sokszor különös kegyetlenséggel történő megvalósítására; illetve az adatgyüjtési rendszerek hiányosságaira, valamint az alacsony jelentéstételi hajlandóság (azaz a látencia) problémájára.

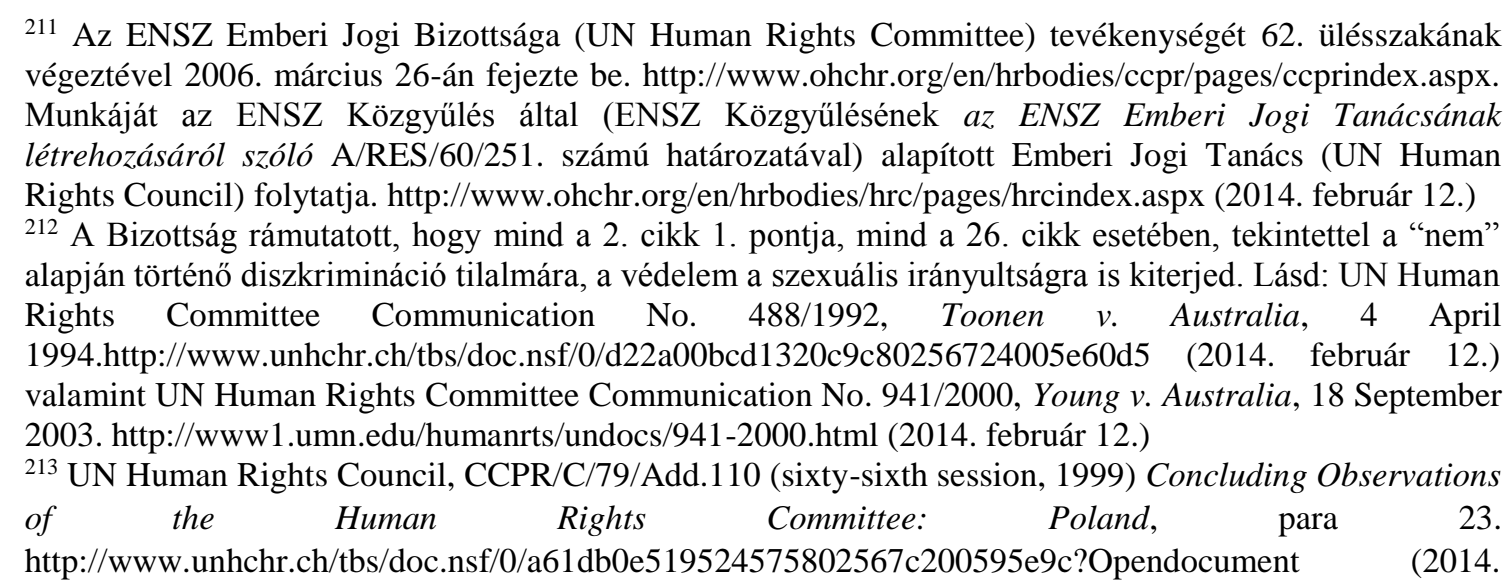
február 12.)

${ }^{214}$ UN Human Rights Council, A/HRC/17/19 (seventeenth session, 2011) Human rights, sexual orientation and gender identity. ny.un.org/doc/UNDOC/GEN/G11/148/76/PDF/G1114876.pdf?OpenElement (2014. február 17.)

${ }^{215}$ UN High Commissioner for Human Rights. http://www.ohchr.org/EN/Pages/WelcomePage.aspx

${ }^{216}$ Report of the UN High Commissioner for Human Rights, A/HRC/19/41 (nineteenth session, 2011) Discriminatory laws and practices and acts of violence against individuals based on their sexual orientation and gender identity.http://www2.ohchr.org/english/bodies/hrcouncil/docs/19session/A.HRC.19.41_English.pdf (2014. február 19.) 
Az ENSZ Emberi Jogi Tanácsának 2008 óta müködő, az emberi jogok betartásának ellenőrzését célzó, egyetemes időszakos felülvizsgálata ${ }^{217}$ az első olyan ellenőrzési mechanizmus, amely az ENSZ valamennyi tagállamában ellenőrizni tudja az emberi jogok betartását. Az eljárás során minden ENSZ-tagállam ellenőrzés alá kerül minden negyedik évben.

Magyarország első jelentése 2011-ben készült el. ${ }^{218}$ A javaslatok interaktív párbeszéd során fogalmazódtak meg, amelynek során például az Egyesült Államok azt javasolta, hogy Magyarország helyezzen nagyobb hangsúlyt a homofóbia által motivált büncselekményekkel szembeni védelemre, és szervezzen az ilyen típusú erőszakkal kapcsolatban tudatosságnövelő kampányokat, a nyomozóhatóság munkatársainak bevonásával. A Koreai Köztársaság álláspontja szerint konkrét intézkedésekre van szükség az előítélet motiválta bűncselekmények megelőzése terén, különös tekintettel a romákkal szembeni rasszista cselekményekre. Indonézia javaslata szerint a rasszista és gyülöletmotiválta büncselekmények esetében biztosítani kell, hogy ezen cselekmények nyomozása hatékony és teljes körü legyen, és a magyar büntető törvénykönyvben meghatározott tényállásokat alkalmazni kell a vádemelés során. Emellett rámutatott a roma nemzetiségi önkormányzatokkal és civil szervezetekkel való együttműködés és az országos szintü adatgyüjtés jelentőségére. Ausztria javasolta, hogy Magyarország biztosítsa az áldozatok számára a jogi segítségnyújtáshoz és védelemhez való teljes körü hozzáférést. Kanada mint a gyülölet-büncselekmények elleni állami fellépés terén kiterjedt tapasztalatokkal rendelkező állam javasolta, hogy biztosítsanak képzést a rendőrségi, ügyészségi és bírósági szakemberek számára a gyülölet-bűncselekményekre vonatkozóan, különös tekintettel a motiváció felismerésére.

2011-ben válasz is született Magyarország részéről a jelentésre és az abban foglalt javaslatokra vonatkozóan. ${ }^{219}$ Azonban a válasza érdemi reakciókat lényegében nem

${ }^{217}$ Universal Periodic Review, UPR. http://www.ohchr.org/en/hrbodies/upr/pages/uprmain.aspx (2014. február 12.)

${ }^{218}$ UN Human Rights Council, A/HRC/18/17 (eighteenth session, 2011) Report of the Working Group on the Universal Periodic Review Hungary. http://daccess-ddsny.un.org/doc/UNDOC/GEN/G11/145/34/PDF/G1114534.pdf?OpenElement (2014. március 3.)

${ }^{219}$ UN Human Rights Council, A/HRC/18/17/Add.1 (Eighteenth session) Report of the Working Group on the Universal Periodic Review. Hungary. Addendum. Views on conclusions and/or recommendations, voluntary commitments and replies presented by the State under review. 14 September 2011. http://www2.ohchr.org/english/bodies/hrcouncil/docs/18session/A-HRC-18-17-Add1.pdf (2014. március 3.) 
tartalmaz a gyülöletvezérelte büncselekményekkel kapcsolatos felvetésekre vonatkozóan. Egy ponton említi a válasz a gyülölet-büncselekményeket: „a magyar bünügyi nyilvántartási rendszer és a bűnügyi statisztikai rendszer már gyüjt adatokat a rasszista és gyülölet-büncselekményekre vonatkozóan". ${ }^{20}$ Kétségtelen, hogy már akkoriban is gyüjtöttek szük körben ${ }^{221}$ adatokat az elöítélet-vezérelte büncselekményekre vonatkozóan. De tekintettel arra, hogy az indonéz fél javaslata arra vonatkozott, hogy Magyarország hozzon létre és müködtessen egy országos adatgyüjtési rendszert a rasszista incidensekre és gyülölet-büncseleményekre vonatkozóan, ${ }^{222}$ erős túlzás és már-már cinizmus az magyar állam részéről akként reagálni e javaslatra, hogy már van ilyen működő rendszer.

A faji megkülönböztetés valamennyi formájának kiküszöböléséről szóló nemzetközi egyezmény ${ }^{223}$ értelmében Magyarország kötelezi magát arra, hogy lépéseket tesz annak érdekében, hogy fajra, nemre, nyelvre vagy vallásra való különbség nélkül elömozdítsa és segítse az emberi jogok és alapvető szabadságjogok egyetemes tiszteletben tartását és biztosítását. A 4. cikk a) pontja értelmében az államok kötelesek a csoportoknak a faji vagy etnikai alapú gyülölettel és erőszakkal szembeni védelmét célzó törvényhozási intézkedéseket elfogadni, így kötelezettséget vállalnak, hogy büntetendő cselekménnyé nyilvánítják „bármely faj, illetve más színü vagy más etnikai származású személyek csoportja elleni irányuló minden erőszakos cselekedetet vagy arra való izgatását, továbbá fajgyülölö tevékenység mindenféle támogatását, annak pénzelését is beleértve”. Az egyezményben foglalt kötelezettségek ellenőrzésére a felek létrehozták a faji megkülönböztetés megszüntetéséért felelős bizottságot, a CERD-et, ${ }^{224}$ amely értékeli a tagállamok által benyújtott jelentéseket, valamint hatáskörébe tartozik az egyéni panaszok kivizsgálása is. ${ }^{225}$

\footnotetext{
${ }^{220}$ UN Human Rights Council, A/HRC/18/17/Add.1. 2.

221 Ezek az adatok közel sem adtak teljes képet a gyülölet-büncselekmények magyarországi valós kiterjedéséről. Erre lásd bővebben a dolgozat $A$ hazai szabályozásról és jogalkalmazásról c. fejezetét.

${ }^{222}$ UN Human Rights Council, A/HRC/18/17. 95.19. para.

223 Nemzetközi egyezmény a faji alapú hátrányos megkülönböztetés valamennyi formájának kiküszöböléséröl (International Convention on the Elimination of All Forms of Racial Discrimination) U.N.T.S. No. 9464, Vol. 660, 1969, 212. (Magyarországon kihirdette az 1969. évi 8. törvényerejü rendelet.)

224 Committee on the Elimination of Racial Discrimination, CERD. http://www2.ohchr.org/english/bodies/cerd/ (2014. február 12.)

225 Majtényi Balázs: Az ENSZ és a kisebbségek védelme, Kisebbségkutatás, 12. évf., 2003/1. http://www.hhrf.org/kisebbsegkutatas/kk_2003_01/cikk.php?id=489 (2014. február 11.)
} 
A Bizottság rámutatott, hogy amennyiben az állam nem nyújt hatékony védelmet a rasszista támadásokkal szemben, illetve nem veszi figyelembe megfelelően a rasszista motivációt a nyomozás során, akkor ezzel megfosztja az adott személyt a hatékony védelemhez és jogorvoslathoz való jogától, amely pedig az egyezmény 6. és 2. cikk 1. pont d) alpont sérelmét jelenti. ${ }^{226}$ A CERD L.K. Hollandia elleni ügyében ${ }^{227}$ rámutatott, hogy nem csupán erőszak, hanem erőszakkal való fenyegetés esetében is terheli az államot a nyomozás gyors és kellő körültekintéssel történő lefolytatásának kötelezettsége. Megemlíthető ezen kívül a CERD azon ajánlása, ${ }^{228}$ amelyben arra hívja fel a részes államok figyelmét, hogy a faji megkülönböztetés bizonyos formái - például az erőszakos cselekmények - sok esetben eltérő módon, illetve eltérő mértékben sújtják a férfiakat és a nőket. ${ }^{229}$

A nőkkel szembeni megkülönböztetés minden formájának felszámolásáról szóló nemzetközi egyezmény ${ }^{230}$ létrehozta a nőkkel szemben alkalmazott megkülönböztetések kiküszöbölésének kérdéseivel foglalkozó bizottságot, a CEDAW-t, ${ }^{231}$ amely 19. számú általános állásfoglalásában ${ }^{232}$ rámutatott, hogy az egyezmény 1 . cikkében meghatározott megkülönböztetés fogalmába beletartozik a nemen alapuló erőszak valamennyi formája, azaz amikor egy nő ellen irányuló erőszak a neme miatt éri az áldozatot. Az egyezmény 2. cikk e) pontja kimondja, hogy az államoknak minden szükséges intézkedést meg kell tenniük, hogy kiküszöböljék a nőkkel szembeni megkülönböztetést. Ezzel kapcsolatban a CEDAW rámutatott, hogy az általános érvényü nemzetközi jogi szabályok és emberi jogi egyezmények értelmében az államot a magánszemélyek, szervezetek és vállalatok

${ }^{226}$ UN CERD Communication No. 46/2009 (eightieth session, 2012), Dawas and Shava $v$. Denmark.http://www2.ohchr.org/english/bodies/cerd/docs/jurisprudence/CERD-C-80-D-46-2009_en.pdf (2014. február 12.)

${ }^{227} \mathrm{UN}$ CERD, Communication No. 4/1991 (forty-second session, 1993), L.K. v. The Netherlands.http://www1.umn.edu/humanrts/country/decisions/CERD-DLR.htm (2014. február 17.)

${ }^{228}$ UN CERD General Recommendation No. 25 (fifty-sixth session, 2000) Gender related dimensions of Racial discrimination. http://www.unhchr.ch/tbs/doc.nsf/0/76a293e49a88bd23802568bd00538d83?Opendocument (2014. február 12.)

\footnotetext{
${ }^{229}$ Balogh Lídia [et al.]: Antidiszkriminációs és esélyegyenlöségi alapismeretek, L’Harmattan, Budapest, 2009, 31 .

${ }^{230}$ A nökkel szembeni megkülönböztetés minden formájának felszámolásáról szóló egyezmény (Convention on the Elimination of All Forms of Discrimination against Women), U.N.T.S. Vol. 1249, 1979, 13. (Magyarországon kihirdette az 1982. évi 10. törvényerejü rendelet.)
}

231 Committee on the Elimination of Discrimination against Women, CEDAW. http://www.un.org/womenwatch/daw/cedaw/committee.htm (2014. február 12.)

${ }^{232}$ UN CEDAW General Recommendation No. 19 (eleventh session, 1992), Violence against women. http://www.un.org/womenwatch/daw/cedaw/recommendations/recomm.htm (2014. február 19.) 
cselekményei esetében is felelősség terhelheti, amennyiben elmulasztott kellő körültekintéssel eljárni az ilyen típusú megkülönböztetés, illetve erőszak megelőzése, felderítése, szankcionálása, illetve a kárenyhítés biztosítása során. Az állásfoglalás egy széles körben osztott nemzetközi aggodalmat is megfogalmazott:hogy a nők - nemük okán - továbbra is többszörös diszkrimináció áldozatai.

A kínzás és más kegyetlen, embertelen vagy megalázó büntetés vagy bánásmód elleni nemzetközi egyezmény ${ }^{233}$ létrehozta a kínzás elleni bizottságot, a CAT-ot, ${ }^{234}$ amely egyrészt figyelemmel kíséri az egyezmény betartását, másrészt kivizsgálja a kínzással kapcsolatos vádakat, az érintett államokkal együttmüködve. A 2. cikk átültetése kapcsán született általános állásfoglalásában ${ }^{235}$ a Bizottság rendelkezik a diszkrimináció vagy marginalizáció által sújtott, sérülékeny egyének és csoportok védelméről. Az államok kötelezettsége, hogy az egyezményben foglalt jogokat minden személy számára; fajra, bőrszínre, etnikai származásra, korra, vallási hovatartozásra vagy meggyőződésre, nemzeti vagy társadalmi származásra, nemre, szexuális irányultságra, nemi identitásra, szellemi vagy más fogyatékosságra, egészségügyi állapotra, a fogva tartás indokaira ideértve politikai büncselekmények, terrorcselekmények elkövetőit is -, illetve más helyzetre tekintet nélkül biztosítsa; menedékkérők, menekültek vagy más nemzetközi védelem alatt állók számára is. Az államoknak azáltal is biztosítani kell a védelmet e csoportok tagjai számára, hogy minden erőszakos cselekményt teljes körüen kivizsgálnak és megbüntetnek, valamint további intézkedéseket tesznek a megelőzés és védelem érdekében.

A 2008-ban elfogadott, fogyatékossággal élő személyek jogairól szóló egyezmény 236 16. cikke rendelkezik a kizsákmányolástól, erőszaktól és visszaéléstől való védelemről, figyelembe véve a nemi szempontokat is.

\footnotetext{
233 Nemzetközi egyezmény a kínzás és más kegyetlen, embertelen vagy megalázó büntetések vagy bánásmódok ellen (Convention Against Torture and Other Cruel, Inhuman or Degrading Treatment or Punishment) U.N.T.S. No. 24841, Vol. 1465, 1987, 85. (Magyarországon kihirdette az 1988. évi 3. törvényerejü rendelet.)

${ }^{234}$ Committee against Torture, CAT. http://www.ohchr.org/en/hrbodies/cat/pages/catindex.aspx (2014. február 12.)

${ }^{235}$ UN CAT General Comment 2, U.N. Doc. CAT/C/GC/2/CRP. 1/Rev.4. (thirty-ninth session, 2007), Implementation of article 2 by States Parties. http://www1.umn.edu/humanrts/cat/general_comments/catgencom2.html (2014. február 17.)

${ }^{236}$ A fogyatékossággal élö személyek jogairól szóló egyezmény (Convention on the Rights of Persons with Disabilities) A/61/611 (Magyarországon kihirdette e a 2007. évi XCII. törvény.)
} 


\section{Európa Tanács}

Az Emberi Jogok és Alapvető Szabadságok Európai Egyezményének ${ }^{237}$ (Emberi Jogok Európai Egyezménye) 14. cikke kimondja, hogy az Egyezményben meghatározott jogokat „minden megkülönböztetés, például nem, faj, szín, nyelv, vallás, politikai vagy egyéb vélemény, nemzeti vagy kisebbséghez tartozás, vagyoni helyzet, születés szerinti vagy egyéb helyzet alapján történő megkülönböztetés nélkül’' kell biztosítani.

Az Egyezmény értelmezésének jogával felruházott Emberi Jogok Európai Bírósága 238 számos döntésében e cikk alapján mondta ki a fokozott büntetőjogi védelem kötelezettségét. A gyülölet-büncselekményekkel kapcsolatos gyakorlat alapjait Nachova és mások Bulgária elleni ügyében ${ }^{239}$ teremtette meg a Bíróság, amelyben kimondta, hogy a bolgár hatóságok elmulasztották kellő körültekintéssel vizsgálni az ügy esetleges rasszista motívumait, ami megvalósította az élethez való jog és a hátrányos megkülönböztetés tilalma együttes sérelmét. Emellett rámutatott, hogy az erőszakos büncselekmények - így különösen az élet elleni cselekmények - esetében, ha azt hivatalos személy követi el, az államot kiemelt kötelezettség terheli, hogy minden lehetséges lépést megtegyen az esetleges rasszista motiváció feltárása és annak megállapítása érdekében, hogy a gyülölet vagy előítélet szerepet játszott-e az ügyben.

Ugyanezen érvelést alkalmazta a Bíróság Šečić Horvátország elleni ügyében, ${ }^{240}$ ahol szintén rámutatott az államot terhelő kötelezettségekre elöítélet-motiváció gyanúja esetén, valamint kifejtette, hogy ha az államok a faji indokból elkövetett erőszakot és brutalitást a nem rasszista indítékú bűncselekményekkel azonos módon kezelnék, azzal szemet hunynának az alapvető jogok érvényesülésére különösen veszélyes cselekmények sajátos természete felett.

237 Egyezmény az emberi jogok és alapvető szabadságok védelméröl (European Convention for the Protection of Human Rights and Fundamental Freedoms) E.T.S. No. 005. (Magyarországon kihirdette az 1993. évi XXXI. törvény.)

${ }^{238}$ European Court of Human Rights, ECtHR. http://www.echr.coe.int/Pages/home.aspx?p=home (2014. február 12.)

${ }^{239}$ ECtHR, Case of Nachova and Others v. Bulgaria, Nos. 43577/98 and 43579/98, 6 July 2005. http://hudoc.echr.coe.int/sites/eng/pages/search.aspx?i=001-69630\#\{"itemid":["001-69630"]\} (2014. február 16.)

${ }^{240} \mathrm{ECtHR}, \quad$ Case of Šečić v. Croatia, No. 40116/02, 31 August 2007. http://hudoc.echr.coe.int/sites/eng/pages/search.aspx?i=001-80711\#\{"itemid":["001-80711"]\} (2014. február 15.) 
A fent említett tételre hivatkozott a Bíróság Milanović Szerbia elleni ügyében ${ }^{241}$ is, és elfogadhatatlannak ítélte, hogy a vallási gyülöleten alapuló motiváció alapos gyanúja ellenére az ügyben éveken keresztül nem történt meg az elkövetők azonosítása és vád alá helyezése. A Bíróság több ponton rámutatott a nyomozó szervek mulasztásaira, tekintettel arra, hogy a sértettet számos támadás érte 2001 és 2007 között, és annak ellenére, hogy nyilvánvaló volt a vallási hovatartozással kapcsolatos indíték, például az, hogy a támadások többnyire június-július hónapban történtek - egyidőben vagy nem sokkal egy fö vallási ünnepet követően -, a hatóságok nem tettek semmit a megelőzés érdekében: nem helyeztek ki megfigyelő kamerát, nem alkalmaztak járöröket, illetve nem vezettek be semmilyen speciális védelmi intézkedést,amellyel megakadályozhatták volna a későbbi támadásokat.

Vejdeland és mások Svédország elleni ügyében ${ }^{242}$ a Bíróság rámutatott, hogy a szexuális irányultság ugyanúgy a személyiség lényeges elemének tekintendő, és a faji, etnikai vagy vallási hovatartozással azonos elbírálás alá esik.

A Bíróság több más ügy mellett Smith és Grady Egyesült Királyság elleni ügyében ${ }^{243}$ is megállapította a 14. cikk sérelmét a kérelmezőket szexuális irányultságuk alapján ért diszkrimináció okán, és döntésében ismételten arra az álláspontra helyezkedett, hogy a szexuális irányultság azonos elbírálás alá esik más védett tulajdonságokkal.

Az Európa Tanács nemzeti kisebbségek védelméről szóló keretegyezményének ${ }^{244} 6$. cikkében a felek kötelezettséget vállalnak, hogy „,megfelelö intézkedéseket hoznak az olyan személyek védelmében, akik hátrányosan megkülönböztetö, ellenséges vagy eröszakos fenyegetések és cselekedetek áldozatai lehetnek etnikai, kulturális, nyelvi vagy vallási identitásuk miatt”.

\footnotetext{
${ }^{241}$ ECtHR, Case of Milanović v. Serbia, No. 44614/07, 14 December 2010. http://echr.ketse.com/doc/44614.07-en-20101214/view/ (2014. február 15.)

242 ECtHR, Case of Vejdeland and Others v. Sweden, No. 1813/07, 9 August 2012. http://hudoc.echr.coe.int/sites/eng/pages/search.aspx?i=001-109046\#\{"itemid":["001-109046"]\} (2014. február 14.)

${ }^{243}$ ECtHR, Case of Smith and Grady v. The United Kingdom, Nos. 33985/96 and 33986/96, 27 September 1999. http://hudoc.echr.coe.int/sites/eng/pages/search.aspx?i=001-58408\#\{"itemid":["001-58408"]\} (2014. február 14.)

${ }^{244}$ Keretegyezmény a nemzeti kisebbségek védelméröl (Framework Convention for the Protection of National Minorities) ETS. No. 157, 1995. (Magyarországon kihirdette az 1999. évi XXXIV. törvény) http://www.hungarian-human-

rights.eu/Strasbourgi\%20keretegyezmeny\%20a\%20kisebbsegek\%20vedelmerol\%201995.pdf február 19.)

$(2014$.
} 
A Miniszteri Bizottság CM/Rec (2010) 5. számú ajánlása a szexuális irányultság, illetve nemi identitás alapján történő diszkrimináció leküzdését célzó intézkedésekről ${ }^{245}$ szóló, I. számú mellékletének A. pontja kifejezett ajánlásokat fogalmaz meg mind a jogalkotás, mind a jogalkalmazás számára a gyülölet-büncselekmények és egyéb gyülölet által motivált incidensekre vonatkozóan. Így az ajánlás értelmében a tagállamoknak biztosítaniuk kell gyülöletmotiváció gyanúja esetén a hatékony, gyors és pártatlan kivizsgálást, valamint - figyelemmel a Bíróság gyakorlatára - az ajánlás rámutat arra, hogy a kivizsgálást különös figyelemmel kell kísérni, ha a cselekményt a gyanú szerint rendvédelmi szervek munkatársai vagy más hivatalos személyek követték el. Az ajánlás utal a büntetés-végrehajtás során tapasztalható incidensekre, büncselekményekre, és felhívja a tagállamokat a bebörtönzött vagy szabadságuktól más módon megfosztott személyek - beleértve leszbikus, meleg, biszexuális és transznemü személyek - biztonságának és méltóságának biztosítására, illetve arra, hogy tegyenek óvintézkedéseket a többi fogvatartott és a személyzet által elkövetett fizikai bántalmazás, nemi erőszak, valamint szexuális visszaélés egyéb formái ellen,megfelelő védelmet biztosítva a transznemü személyek számára is. Az ajánlás kitér a jogalkalmazó szervek tagjainak speciális képzettsége, valamint a megfelelő adatgyüjtés jelentőségére.

Az Európa Tanács Parlamenti Közgyülése is több ajánlást, határozatot bocsátott ki a rasszizmus, idegengyülölet, antiszemitizmus és intolerancia tárgyában, ${ }^{246}$ felhívva a Miniszteri Bizottságot és a tagállamokat e jelenségek megelőzését, illetve kezelését szolgáló intézkedések megtételére.

Az Európa Tanács Rasszizmus és Intolerancia elleni Bizottságának ${ }^{247}$ - 1993-ban való létrejötte óta - a rasszizmus, az idegengyülölet, az antiszemitizmus és az intolerancia

\footnotetext{
${ }^{245}$ A Miniszteri Bizottság CM/REC(2010)5. sz. ajánlása a tagállamok felé a szexuális irányultság, illetve nemi identitás alapján történő diszkrimináció leküzdését célzó intézkedésekröl (Recommendation $\mathrm{CM} / \operatorname{Rec}(2010) 5$ of the Committee of Ministers to member stateson measures to combat discrimination on grounds of sexual orientation or gender identity)1081st meeting of the Ministers' Deputies, 2010. http://www.kormany.hu/download/3/8d/80000/CM-Rec-2010-5-ajanlas.pdf (2014. február 16.)
}

${ }^{246}$ Lásd pl. Parliamentary Assembly Recommendation 1222 (1993) on the fight against racism, xenophobia and intolerance. http://www.assembly.coe.int//Main.asp?link=http://www.assembly.coe.int/Documents/AdoptedText/TA9 3/EREC1222.HTM (2014. március. 5.) ill. Parliamentary Assembly Recommendation 1275 (1995) on the fight against racism, xenophobia, anti-Semitism and intolerance. http://assembly.coe.int/Main.asp?link=/Documents/AdoptedText/ta95/EREC1275.htm (2014. február 12.)

${ }^{247}$ European Commission against Racism and Intolerance, ECRI. http://www.coe.int/t/dghl/monitoring/ecri/default_en.asp (2014. február 12.) 
elleni küzdelem a legfőbb feladata. ${ }^{248} \mathrm{Az}$ évek során a Bizottság számos általános ajánlást és országjelentést bocsátott ki, amelyek általános érvényü ajánlásokat fogalmaznak meg a tagországok számára. Az 1. számú általános ajánlás 249 hangsúlyozza, hogy a rasszizmus, intolerancia és antiszemitizmus jelenségének leküzdéséhez a jogi eszközök kiemelkedő jelentőségüek, és a hatályos jogszabályok végrehajtásának elmulasztása e jelenségek elleni fellépést hiteltelenné teszi. Felhívja a tagállamokat, hogy a rasszista és idegengyülöletből fakadó cselekedeteket szigorúan büntessék, például önálló tényállások létrehozása révén, illetve az elöítélet-motivációt vegyék figyelembe a büntetések kiszabása során. Az ajánlás szerint a tagállamoknak biztosítaniuk kell, hogy az ilyen büncselekmények kivizsgálása elsőbbséget élvezzen, az eljárást hatékonyan és következetesen folytassák le és, hogy pontos adatok és statisztikai kimutatások készüljenek és jelenjenek meg.

A 3. számú általános ajánlás ${ }^{250}$ kifejezetten a romákkal szembeni rasszizmus és intolerancia elleni küzdelem vonatkozásában hívja fel a tagállamokat, hogy a roma kisebbség tagjaival szemben elkövetett büncselekmények ne maradjanak büntetlenül, és az ilyen esetek kapjanak publicitást. Az ajánlás rávilágít, hogy kiemelt figyelmet kell szentelni a roma nők helyzetére, akiket a hátrányos megkülönböztetés gyakran kétszeresen is sújt.

Az ECRI 4. számú általános ajánlása ${ }^{251}$ javasolja a tagállamok kormányainak, hogy végezzenek országos felméréseket a potenciális áldozatok rasszizmussal és hátrányos megkülönböztetéssel kapcsolatos tapasztalatairól és benyomásairól.

${ }^{248}$ Nemzeti és Etnikai Kisebbségi Jogok Országgyülési Biztosa: Beszámoló a Nemzeti és Etnikai Kisebbségi Jogok Országgyülési Biztosának tevékenységéröl, 1998. január 1.-1998. december 31. http://www.kisebbsegiombudsman.hu/word/08-06-2008_13_55_16/beszámoló_2008.html (2014. február 19.)

${ }^{249}$ ECRI 1. sz. általános ajánlása: Küzdelem a rasszizmus, az idegengyülölet, az antiszemitizmus és az intolerancia ellen (ECRI General Policy Recommendation No. 1: Combating racism, xenophobia, antisemitism and intolerance) CRI(96)43 rev. 1996. http://www.europatanacs.hu/pdf/ECRI_1.pdf (2014. február 19.)

${ }^{250}$ ECRI 3. sz. általános ajánlása: Küzdelem a romákkal/cigányokkal szembeni rasszizmus és intolerancia ellen (ECRI General Policy Recommendation No. 3: Combating racism and intolerance against Roma/Gypsies) CRI(98)29 rev. 1998. http://www.europatanacs.hu/pdf/ECRI_3.pdf (2014. február 19.)

${ }^{251}$ ECRI 4. sz. általános ajánlása: A potenciális áldozatok hátrányos megkülönböztetéssel és rasszizmussal kapcsolatos tapasztalatairól és benyomásairól végzett országos felmérések (ECRI General Policy Recommendation No. 4: National surveys on the experience and perception of discrimination and racism 
Az 5. számú ajánlás ${ }^{252}$ kifejezetten a muszlimokkal szembeni intolerancia és diszkrimináció elleni küzdelemről szól, míg a 7. számú ajánlás ${ }^{253}$ a rasszizmusra és a faji megkülönböztetésre vonatkozó nemzeti jogalkotásra tesz javaslatokat; többek között sürgeti a faj, bőrszín, nyelv, vallás, állampolgárság, nemzeti és etnikai származás miatti fenyegetés kriminalizálását.

A 9. számú általános ajánlás ${ }^{254}$ az antiszemitizmus elleni küzdelemről szól: felhívja a tagállamokat annak biztosítására, hogy a rasszizmussal kapcsolatban megalkotott büntető jogszabályok az antiszemitizmusra is terjedjenek ki, és a - súlyosító vagy minősítő körülményként meghatározott - rasszista indíték az antiszemita indítékot is foglalja magába. Az ajánlás megjelöl bizonyos cselekményeket, amelyek szándékos elkövetés és antiszemita motiváció esetén antiszemita büncselekményt valósítanak meg; ebbe a körbe vonva a rágalmazást, becsületsértést, fenyegetést, holokauszttagadást, dolog elleni erőszakos cselekményeket (zsidó tulajdon, illetve müemlék antiszemita indítékú megszentségtelenítése, meggyalázása). Az ajánlás felszólítja a tagállamokat arra, hogy nyújtsanak megfelelő képzést a büntető igazságszolgáltatás területén dolgozók számára az antiszemita büncselekményekről, illetve az azokkal szembeni fellépésről.

A 11. számú ajánlás ${ }^{255}$ a rendészet területére vonatkozóan fogalmaz meg javaslatokat; ennek során kitér a rendőrség szerepére a rasszista büncselekményekkel szembeni küzdelemben és a rasszista indcidensek monitorozásában. A nyomozás alaposságára, a bejelentések ösztönzésére és az adatgyüjtési rendszerre vonatkozó ajánlások mellett

\begin{tabular}{lllllll}
\hline from the point of view of potential victims) & CRI(98)30, 1998.
\end{tabular}
http://www.europatanacs.hu/pdf/ECRI_4.pdf (2014. február 19.)

${ }^{252}$ ECRI 5. sz. általános ajánlása: A muszlimokkal szembeni intolerancia és diszkrimináció elleni küzdelemröl(ECRI General policy recommendation No. 5: Combating intolerance and discrimination against Muslims) CRI(2000)21, 2000. http://www.europatanacs.hu/pdf/ECRI_5.pdf (2014. február 19.)

${ }^{253}$ ECRI 7. sz. általános ajánlása: A rasszizmus és a faji megkülönböztetés elleni küzdelem a nemzeti jogalkotásban (ECRI General Policy Recommendation No. 7: National Legislation to Combat Racism and Racial Discrimination) CRI(2003)8, 2002. http://www.europatanacs.hu/pdf/ECRI_7.pdf (2014. február 19.)

${ }^{254}$ ECRI 9. sz. általános ajánlása: Az antiszemitizmus elleni küzdelemröl (ECRI General Policy Recommendation No. 9: The fight against antisemitism) CRI(2004)37, 2004. http://www.europatanacs.hu/pdf/ECRI_9.pdf (2014. február 19.)

${ }^{255}$ ECRI 11. sz. általános ajánlása: A rasszizmus és a faji megkülönböztetés ellen a rendfenntartás területén folytatott küzdelemröl(ECRI General Policy Recommendation No. 11: Combating racism and racial discrimination in policing) CRI(2007)39, 2007. http://www.europatanacs.hu/pdf/ECRI_11.pdf (2014. február 20.) 
felhívja a tagállamokat, hogy alkalmazzák az ajánlásban szereplő fogalommeghatározást, amely szerint rasszista incidens „bármely incidens, amelyet a sértett vagy bármely más személy rasszistának érzékel".

A 13. számú általános ajánlás ${ }^{256}$ a romaellenesség és a romákkal szembeni diszkrimináció elleni küzdelem kapcsán többek között hatékony adatgyüjtési rendszer felállítását sürgeti, illetve azt, hogy szervezzenek speciális képzéseket a büntető igazságszolgáltatás területén dolgozóknak a jogalkalmazás elősegítése érdekében.

Az ECRI Magyarországról szóló első jelentése ${ }^{257}$ rámutatott, hogy a magyar büntetőjog nem fedi le a faji megkülönböztetés és erőszak minden területét, nincsen tiltva például a faji alapon történő rágalmazás és becsületsértés, a mindennapi életben történő megkülönböztetés vagy a hivatali személyek általi diszkrimináció; illetve, hogy a hatályos jogszabályok nem adnak kellő útmutatást a rendőrség számára a gyülöletbüncselekmények azonosításához. A Bizottság kijelentette, hogy nagyobb figyelmet kell szentelni a büntetőeljárás területén dolgozók képzésének.

A második jelentés ${ }^{258}$ rámutatott, hogy még mindig előfordul rendőri bántalmazás a roma kisebbség tagjaival szemben, illetve - ahogy az első jelentés is említette - a bünüldöző szervek képviselői nem mindig viselkednek előírásszerüen, az információk szerint a hatóságok rendszerint nem hajlandóak elismerni a támadások rasszista vagy antiszemita indíttatását, az ilyen jellegü támadásokkal kapcsolatban csak ritkán tesznek feljelentést, és ha van is vádemelés, az nem faji indíttatású támadásra vonatkozik. Figyelembe véve a föként a roma közösség tagjai ellen irányuló, fajilag motivált erőszak és fenyegetés elterjedtségét, az ECRI a releváns büntetőjogi rendelkezések erőteljesebb alkalmazását ajánlotta. A Bizottság álláspontja szerint a jogalkalmazás javítása érdekében kiegészítő intézkedésekre van szükség, beleértve a társadalmi

256 ECRI 13. sz. általános jelentése: Cigányellenesség és a romákkal szembeni diszkrimináció elleni küzdelem (ECRI General Policy Recommendation No. 13: Combating anti-Gypsyism and discrimination against Roma) CRI(2011)37, 2011. http://www.coe.int/t/dghl/monitoring/ecri/activities/gpr/en/recommendation_n13/e-RPG\%2013\%20\%20A4.pdf (2014. március 1.)

${ }^{257}$ ECRI Magyarországról szóló első jelentés (ECRI's country-by-country approach: Report on Hungary) CRI (97) 53, 1997. http://www.coe.int/t/dghl/monitoring/ecri/Country-by-country/Hungary/HUN-CbC-I1997-053-HU.pdf (2014. február 12.)

${ }^{258}$ ECRI Magyarországról szóló második jelentés (Second Report on Hungary) CRI (2000) 5, 2000. http://www.coe.int/t/dghl/monitoring/ecri/country-by-country/hungary/HUN-CbC-II-2000-005-HUN.pdf (2014. február 12.) 
tudatosság növelését a faji erőszak és fenyegetés tilalmával kapcsolatban. A jelentés sajátos akadályként említette, hogy az áldozatok nem bíznak a jogorvoslati lehetőségekben, főként az intézményes rasszizmus miatt, ugyanis a rendőrség sokszor maga is részes a roma közösség tagjai ellen elkövetett erőszakos, illetve fenyegető cselekményekben. Ezért az ECRI hangsúlyozta, hogy különleges figyelmet kell fordítani az áldozatok támogatására és segítésére.

A harmadik jelentésben ${ }^{259}$ a Bizottság az időközben megvalósított intézkedések ellenére aggályát fejezte ki, hogy a helyzet nem sokat változott a büntetőjogi elöírások alkalmazása terén: 1999 és 2002 között nem sok személy ellen folyt eljárás, és kevés esetben hoztak ítéletet rasszizmuson alapuló erőszakos cselekmény kapcsán, azonban ezzel egy időben több forrás is a roma közösségek tagjaival szemben (olykor rendörség tagjai által) elkövetett cselekményekröl számolt be. A javaslatok körében útmutatás található az oktatási kezdeményezésekre, valamint roma rendőrök toborzására vonatkozóan.

A negyedik jelentés ${ }^{260}$ nyomatékosan javasolta, hogy a hatóságok folyamatosan értékeljék a rasszista megnyilvánulások elleni jogszabályok alkalmazhatóságát. A jelentés megállapította, hogy a magyar jogrendszerből hiányzik egy olyan konkrét elkövetési alakzat vagy súlyosbító körülmény, amely a gyülöletindíttatású vagyon elleni büncselekményeket büntetné, következésképpen a tulajdon védelme során nem érvényesül az áldozatok különleges jellemzőinek figyelembe vétele. A jelentés értelmében ajánlott lenne olyan rendelkezések beiktatása a büntető jogszabályok közé, amelyek kifejezetten súlyosító vagy minősítő körülménynek nyilvánítják a faji indíttatást ilyen esetekben.

Nils Muižnieks az Európa Tanács emberi jogok biztosának 2014. július 1. és 4. közötti magyarországi látogatását követően megjelent jelentés ${ }^{261}$ érintette a gyülölet-

\footnotetext{
${ }^{259}$ ECRI Magyarországról szóló harmadik jelentése (Third Report on Hungary) CRI (2004) $25,2004$. http://www.coe.int/t/dghl/monitoring/ecri/Country-by-country/Hungary/HUN-CbC-III-2004-25-HUN.pdf (2014. február 12.)

${ }^{260}$ ECRI Magyarországról szóló negyedik jelentése (ECRI Report on Hungary, fourth monitorting cycle) CRI (2009) 3, 2009. http://www.coe.int/t/dghl/monitoring/ecri/Country-by-country/Hungary/HUN-CbCIV-2009-003-HUN.pdf (2014. február 19.)

${ }^{261}$ Report by Nils Muižnieks Commissioner for Human Rights of the Council of Europe Following His Visit to Hungary from 1 to 4 July 2014. CommDH(2014)21, Strasbourg, 16 December 2014.
} 
büncselekmények kérdéskörét is. A jelentés megállapítja, hogy a gyülöletbüncselekmények száma az elmúlt években fokozatosan nőtt, aminek hátterében a gazdasági válság és a növekvő nacionalista attitüd áll. Az emberi jogi biztos aggodalmát fejezi ki a szélsőséges paramilitáris csoportok müködésével kapcsolatban. A jelentés kiemeli, hogy az elmúlt években a magyar jogalkotó törekedett a gyülöletbeszéd és a gyülölet-büncselekmények visszaszorítására. Ehhez kapcsolódóan példaként említi a holokauszttagadás büntettének beemelését a Btk.-ba, illetve pozitívumként értékeli, hogy az új Btk. több védett csoportra kiterjesztette a közösség tagja elleni erőszak tényállásában biztosított védelmet. A jogi szabályozás hiányosságának tartja viszont a jelentés, hogy a gyülölet-büncselekmények egyes típusai nem szerepelnek a Btk.-ban; így például az előítélet motiválta zaklatás és rongálás. További hiányossága a magyar szabályozásnak, hogy nincs egyértelmüen meghatározva, melyek azok a büncselekmények, amelyek esetében az elöítélet motivációt vizsgálni és minősítő körülményként kellene értékelni.

A jelentés kiemelkedő fontosságúnak tartja a rendőrségen belül felállított, speciálisan a gyülölet-büncselekmények felderítésére szakosodott nyomozókból álló szakvonalat. A jelentés kritikát fogalmaz meg a jogi minősítésekkel kapcsolatban és kiemeli, hogy nagyon kevés gyülölet-büncselekményt regisztrálnak és kevés jut el a vádemelésig. A gyülölet-büncselekményekkel kapcsolatos alulminősítések okaként a speciális képzés hiányát, a váderedményesség magas szintjének elvárását és a túlterhelt bűnüldöző szervezeteket jelöli meg. Ehhez kapcsolódva kiemeli, hogy aggodalomra ad okot az a tendencia, hogy az ügyészség a közösség tagja elleni erőszak bűncselekményét roma elkövetők esetében indokolatlanul is alkalmazza, de üdvözli a bíróságok döntését, hogy egyes ügyekben korrigálták a minősítést. A biztos egyetért a civil szervezetekkel, amelyek a kettős mérce alkalmazásának kockázatára hívták fel a figyelmét: a romák nem kapnak megfelelö védelmet a gyülölet-büncselekményekkel szemben, azonban olykor megalapozatlanul büntetik őket az ilyen támadásokra adott reakcióik miatt. Mindezekből kifolyólag a biztos szorgalmazza, hogy a rendőröknek, ügyészeknek és bíróknak a nemzetközi és hazai civil szervezetekkel együttmüködve szervezzenek képzéseket. Reméli, hogy az oktatással az áldozatvédelem is hangsúlyosabbá válik, illetve a bizalom is növekedni fog az igazságszolgáltatás szervei iránt. 
Végül a jegyzőkönyv kitér arra, hogy a gyülölet-büncselekmények áldozatai nem kapnak megfelelő jogi és pszichológiai támogatást az állami áldozatsegítő rendszertől. Javaslatában megfogalmazza, hogy biztosítani kell az áldozatoknak az igazságszolgáltatás szerveihez való akadálytalan hozzáférést és a megfelelő védelmet. Emellett a jegyzőkönyv javasolja az elöítélet elleni fellépés kérdésében nemzeti akcióterv kidolgozását.

Mindemellett a jelentés külön említi az Emberi Jogok Európai Egyezménye 12. kiegészítő jegyzőkönyvét ${ }^{262}$ - amelyet Magyarország a mai napig nem ratifikált -, és egyben felhívja Magyarországot a ratifikálásra.

\section{Európai Unió}

A hátrányos megkülönböztetés tilalma kezdetben leginkább gazdasági céloknak alárendelten jelent meg az Európai Közösség keretei között. Bármennyire is nem tekintette eredendően céljának az ilyen irányú szerepvállalást az EK, a diszkrimináció tilalmának kiszélesítése az emberi jogi vonatkozású kérdésekre idővel elkerülhetetlenné vált. ${ }^{263}$ Első lépésként 1977-ben deklarálta ezzel kapcsolatos álláspontját az EK, amikor az Európai Parlament, a Tanács és a Bizottság közös nyilatkozatot ${ }^{264}$ tett az emberi jogokról, kifejezve az emberi jogok és szabadságok iránti elkötelezettségüket. 1986-ban a Közösség nyilatkozatot adott ki a rasszizmus és idegengyülölet ellen, ${ }^{265}$ majd a védelem az EU létrejöttével szélesedett ki: az Európai Parlament 1994-ben és 1995-ben is állásfoglalást ${ }^{266}$ bocsátott $\mathrm{ki}$ a rasszizmus, idegengyülölet és antiszemitizmus jelenségei kapcsán, amelyekben olyan felhívásokat intéz a tagállamokhoz, hogy például támogassák anyagilag az állampolgárok és civil szervezetek kezdeményezéseit, a

${ }^{262}$ Protocol No. 12 to the Convention for the Protection of Human Rights and Fundamental Freedoms. CETS No.: 177, Rome, 4 November 2000. http://conventions.coe.int/Treaty/en/Treaties/Html/177.htm (2015. február 10.)

263 Szajbély Katalin-Tóth Judit: „Kisebbségvédelem az Európai Unióban” Kisebbségkutatás, 2002/2. http://www.hhrf.org/kisebbsegkutatas/kk_2002_02/cikk.php?id=1134 (2014. február 12.)

${ }^{264}$ Joint Declaration by the European Parliament, the Council, OJ C 103 1, 27.4.1977. http://www.europarl.europa.eu/charter/docs/pdf/jointdecl_04_77_en_en.pdf (2014. március 5.)

${ }^{265}$ Joint Declaration by the European Parliament, the Council and the Commission against racism and $\begin{array}{llll}\text { xenophobia, } & \text { OJ } & \text { C } & \text { 25.6.1986. }\end{array}$ http://www.europarl.europa.eu/workingpapers/libe/102/text5_en.htm\#annex1 (2014. március 5.)

${ }^{266}$ Resolution of the European Parliament on racism, xenophobia, and anti-semitism, OJ C 323/154, 20.11.1994 and Resolution of the European Parliament on racism, xenophobia and anti-semitism, OJ C 308/140, 20.11.1995. http://www.europarl.europa.eu/workingpapers/libe/102/text5_en.htm\#annex1 (2014. március 5.) 
rasszizmus, idegengyülölet és antiszemitizmus elleni küzdelem terén, fektessenek különös hangsúlyt az intézményes rasszizmus visszaszorítására, ratifikálják a rasszizmus valamennyi formájának leküzdését célzó nemzetközi jogi dokumentumokat, illetve támogassák a Bizottsággal együttmüködve az e jelenségekkel kapcsolatos figyelemfelhívó és tudatosságnövelő oktatásokat, kampányokat, csereprogramokat és hasonló kezdeményezéseket.

Az Európai Unió müködéséről szóló szerződés ${ }^{267}$ 19. cikke rendelkezik a nemen, faji vagy etnikai származáson, valláson vagy meggyőződésen, fogyatékosságon, életkoron vagy szexuális irányultságon alapuló diszkrimináció tilalmáról. A rendelkezést az Amszterdami Szerződés elfogadásával iktatták be az alapító szerződések rendelkezési közé, azzal a körülménnyel, hogy a cikk felhatalmazta a Tanácsot, hogy - az Európai Parlament egyetértését követően - intézkedéseket tegyen a diszkrimináció elleni küzdelem terén. ${ }^{268}$ Emellett a 67. cikk kimondja, hogy az Unió a gyülöletbüncselekmények, a rasszizmus és az idegengyülölet megelőzésére és leküzdésére irányuló intézkedések révén a biztonság magas szintjét kívánja biztosítani.

A személyek közötti, faji- vagy etnikai származásra való tekintet nélküli egyenlő bánásmód elvének alkalmazásáról szóló 2000/43/EK irányelv ${ }^{269}$ szintén a megkülönböztetés tilalmával kapcsolatos rendelkezéseket tartalmaz, tiltva mind a közvetlen, mind a közvetett diszkriminációt.

Az Európai Unió Alapjogi Chartája ${ }^{270}$ 21. cikkében tilt minden megkülönböztetést, „,́gy különösen a nem, faj, szín, etnikai vagy társadalmi származás, genetikai tulajdonságok, nyelv, vallás vagy meggyözödés, politikai vagy más vélemény, nemzeti kisebbséghez tartozás vagyoni helyzet, születés, fogyatékosság, kor vagy szexuális irányultság alapján

\footnotetext{
${ }^{267}$ Az Európai Unió müködéséröl szóló szerzödés egységes szerkezetbe foglalt változata (Treaty on the Functioning of the European Union) HL C 326/47, 2012.10.26. http://eurlex.europa.eu/LexUriServ/LexUriServ.do?uri=OJ:C:2012:326:0047:0200:HU:PDF (2014. február 28.) ${ }^{268}$ Szajbély - Tóth 2002.

${ }^{269}$ A Tanács 2000/43/EK irányelve a személyek közötti, faji- vagy etnikai származásra való tekintet nélküli egyenlö bánásmód elvének alkalmazásáról (Council Directive 2000/43/EC Implementing the principle of equal treatment between persons irrespective of racial or ethnic origin) HL L 180, 2000.07.19. http://eur-lex.europa.eu/LexUriServ/LexUriServ.do?uri=CELEX:32000L0043:hu:HTML (2014. február 16.)

${ }^{270}$ Európai Unió Alapjogi Chartája (Charter of Fundamental Rights of the European Union) HL C 326/391, 2012.10.26. http://eurlex.europa.eu/LexUriServ/LexUriServ.do?uri=OJ:C:2012:326:FULL:HU:PDF (2014. március 5.)
} 
történő megkülönböztetést", ezzel kötelezve az uniós tagállamokat arra, hogy fellépjenek a rasszizmusból, idegengyülöletből, vallási intoleranciából vagy egy személy fogyatékosságával, szexuális irányultságával vagy nemi identitásával kapcsolatos elöítéletből eredő büncselekmények ellen.

Az Európai Parlament 2006-os, „A rasszista és homofób erőszak fokozódásáról Európában" címü állásfoglalásában ${ }^{271}$ mélyen elítél minden rasszista és gyülöletből fakadó támadást, valamint sürgeti a hatóságokat, hogy minden lehetséges lépést tegyenek meg a felelősök megbüntetése érdekében, és vessenek véget a büntetlenség légkörének, amely a támadásokkal kapcsolatban tapasztalható. A Parlament felhívja az Unió valamennyi intézményét, tagállamát, demokratikus európai pártját, hogy ítéljék el az intolerancia minden megnyilvánulását és a zaklatás és rasszista erőszak valamennyi formáját. A nemzeti és nemzetközi együttmüködés jelentőségét elismerve, a tagállamokat a rasszizmus, szexizmus, idegengyülölet és homofóbia elleni küzdelemben való együttmüködésre ösztönzi. Végül emlékezteti a tagállamokat, hogy a gyülöletbüncselekményekkel szembeni hatékony küzdelem érdekében egyértelmü meghatározásokra, valamint statisztikai adatokra van szükség.

A rasszizmussal és idegengyülölettel összefüggő büncselekmények elleni egységes fellépés érdekében 2008. november 28-án elfogadták a Tanács 2008/913/IB kerethatározatát; ${ }^{272}$ azzal a szándékkal, hogy a büntető jogszabályok közelítése és a tagállamok közötti igazságügyi együttmüködés elősegítése révén a rasszista és idegengyülöletből fakadó büncselekmények elleni küzdelem hatásosabb legyen. A határozat - 1. és 2. cikke keretében meghatározott - a rasszizmussal és idegengyülölettel kapcsolatos, szándékos cselekmények ${ }^{273}$ büntetendővé nyilvánítása mellett a tagállamok kötelezettséget vállalnak, hogy meghozzák a szükséges intézkedéseket annak biztosítására, hogy a rasszista és idegengyülölő indíték súlyosbító

${ }^{271} \mathrm{Az}$ Európai Parlament állásfoglalása a rasszista és homofób erőszak fokozódásáról Európában (European Parliament resolution on the increase in racist and homophobic violence in Europe) P6_TA(2006)0273, 2006. http://www.europarl.europa.eu/sides/getDoc.do?pubRef=//EP//NONSGML+TA+P6-TA-2006-0273+0+DOC+PDF+V0//HU (2014. február 18.)

${ }^{272}$ A Tanács 2008/913/IB kerethatározata a rasszizmus és az idegengyülölet egyes formái és megnyilvánulásai elleni, büntetőjogi eszközökkel történö küzdelemröl (Council Framework Decision 2008/913/JHA on combating certain forms of expressions of racism and xenophobia by means of criminal law) HL $\quad$ L $\quad 328, \quad 2008.12 .16 . \quad$ http://eurlex.europa.eu/LexUriServ/LexUriServ.do?uri=CELEX:32008F0913:HU:HTML (2014. február 12.)

${ }^{273}$ Rasszizmussal és idegengyülölettel kapcsolatos büncselekmények többek között a nyilvánosság előtti erőszakra vagy gyülöletre uszítás, továbbá a népirtás, emberiesség elleni vagy háborús bủncselekmények nyilvánosság előtti védelmezése, tagadása vagy jelentéktelen színben való feltüntetése. 
körülménynek számítson, illetve, hogy az ilyen indítékot a bíróságok a büntetés kiszabásánál figyelembe vehessék (4. cikk). A kerethatározat említi, hogy a rasszista és idegengyülöletből fakadó büncselekmények áldozatai különösen sebezhetőek lehetnek,ami visszatarthatja őket az eljárás kezdeményezésétől.

Az Európai Parlament és a Tanács 2012/29/EU áldozatvédelmi irányelvének ${ }^{274} 22$. cikke kimondja, hogy az elöítéleten vagy megkülönböztetésen alapuló indítékkal elkövetett büncselekmények áldozatai különleges védelemre szorulnak, ezért védelmüket a büntetőeljárás során speciális intézkedésekkel kell biztosítani. Az irányelv 23. cikke szól a különleges védelemre szoruló áldozatok jogairól a büntetőeljárás során. E rendelkezés értelmében például a nyomozás során az áldozatok kihallgatását speciális kialakítású helyiségben, speciális képzettségű szakemberek részvételével kell végezni; a bírósági eljárás során biztosítani kell, hogy a tanúvallomás megtételekor az áldozat és az elkövető ne kerüljenek vizuális kapcsolatba, illetve tartózkodni kell az áldozat magánéletére vonatkozó, a büncselekményhez nem kapcsolódó,irreleváns kérdések feltevésétől.

\section{Az Esélyegyenlőségi Szervezetek Nemzetközi Hálózata ${ }^{275}$ (EQUINET) 32 európai} ország 42 egyenlő bánásmód szervezetét tömöríti. A magyar ombudsmani hivatal a hálózat létrejötte (2002-2004) óta részt vesz annak munkájában, melynek célja az európai esélyegyenlőségi jogok megvalósítása elsődlegesen a tagszervezetek képességfejlesztése útján. ${ }^{276} \mathrm{Az}$ ombudsmani hivatal mellett az Egyenlő Bánásmód Hatóság $(\mathrm{EBH})^{277}$ is tagja a hálózatnak Magyarországról. Az EQUINET rendszeresen szervez tréningeket tagszervezetei számára. A magyar nemzetiségi különbiztosok korábbi tagságát megújítva az egységes ombudsmani intézmény munkatársai rendszeresen

\footnotetext{
${ }^{274}$ Az Európai Parlament és a Tanács 2012/29/EU irányelve a büncselekmények áldozatainak jogaira, támogatására és védelmére vonatkozó minimumszabályok megállapításáról és a 2001/220/IB tanácsi kerethatározat felváltásáról (Directive 2012/29/EU of the European Parliament and of the Council establishing minimum standards on the rights, support and protection of victims of crime, and replacing Council Framework Decision 2001/220/JHA). HL L 315/57, 2012.11.14. http://eurlex.europa.eu/LexUriServ/LexUriServ.do?uri=OJ:L:2012:315:0057:0073:HU:PDF (2014. február 17.) 275 European Network of Equality Bodies, EQUINET. http://www.equineteurope.org/

276 Alapvető jogok biztosának hivatala: Beszámoló az alapvetö jogok biztosának és helyetteseinek tevékenységéröl 2014. https://www.ajbh.hu/documents/10180/2119301/AJBH+Besz\%C3\%A1mol\%C3\%B3\%202014/e4cb6abb2b16-4f67-bcdf-e24ccb74cca2;jsessionid=A007B79F919184B39100BAEFFBD8C291?version=1.0 (2015. február 10.)

${ }^{277}$ Egyenlő Bánásmód Hatóság (EBH). http://www.egyenlobanasmod.hu/
} 
vettek részt a nemzetközi szervezet munkájában. ${ }^{278}$ Az Equinet szervezésében például 2013 májusában, Brüsszelben a Faji irányelv és a Foglalkoztatási keretirányelv alkalmazásáról tartott jogi szemináriumon gyakorló jogászok vettek részt a különböző esélyegyenlőséggel és egyenlő bánásmóddal foglalkozó nemzeti testületektől. ${ }^{279}$ Emellett az Equinet Esélyegyenlőségi jog a gyakorlatban (Equality Law in Practice) nevü munkacsoportra 2013 márciusában tartott megbeszélésének témáját a faji irányelv alkalmazásáról szóló jelentés képezte. ${ }^{280}$

Az 1997-es évet a tagállamok az Rasszizmus Elleni Európai Évnek nyilvánították, majd az EU és az Európa Tanács együttmüködésében létrejött a Rasszizmus és Idegengyülölet Európai Megfigyelőközpontja. ${ }^{281}$ A Tanács 1035/97/EK rendeletével ${ }^{282}$ létrehozott központ célja az volt, hogy objektív, megbízható és európai szinten összehasonlítható információkat nyújtson a Közösség és a tagállamok számára a rasszizmus, az idegengyülölet és az antiszemitizmus jelenségeiről. A Tanács 168/2007/EK rendelete ${ }^{283}$ a Megfigyelőközpontra építve létrehozta az Európai Unió Alapjogi Ügynökségét, ${ }^{284}$ amelynek munkája továbbra is kiterjed a rasszizmus, az idegengyülölet és az antiszemitizmus jelenségeire, valamint a kisebbségekhez tartozó személyek jogainak védelmére, továbbá a nemek közötti egyenlőségre.

A FRA két jelentést adott ki a gyülölet-büncselekményekről, amelyek összehasonlító elemzést adnak a meglévő jogi keretekről, az elöítéletből eredő büncselekményekre vonatkozó egyéni tapasztalatokról és 27 uniós tagállamban folyó hivatalos adatgyüjtés

278 Alapvető jogok biztosának hivatala: Beszámoló az alapvetö jogok és helyetteseinek 2012. évi tevékenységéröl.

http://www.ajbh.hu/documents/10180/129110/AJBH+Besz\%C3\%A1 mol\%C3\%B3\%202012/9215dc04-

4031-451e-b79c-eff2e2e63925 (2015. február 10.)

279 EBH: Egyenlő Tájékoztató az Egyenlő Bánásmód Hatóság 2013. évi tevékenységéröl. http://www.egyenlobanasmod.hu/article/view/tajekoztato-az-egyenlo-banasmod-hatosag-2013-evitevekenysegerol-3 (2015. február 10.)

${ }^{280}$ Lásd uo.

${ }^{281}$ European Monitoring Centre of Racism and Xenophobia, EUMC. http://europa.eu/legislation_summaries/other/c10411_en.htm (2014. február 17.)

${ }^{282}$ A Tanács 1035/97/EK rendelete a Rasszizmus és Idegengyülölet Európai Megfigyelöközpontjának létrehozásáról [Council Regulation (EC) No 1035/97 establishing a European Monitoring Centre on Racism and Xenophobia] HL L 151, 1997.6.2. http://eurlex.europa.eu/LexUriServ/LexUriServ.do?uri=OJ:L:1997:151:0001:001:HU:HTML (2014. február 17.)

${ }^{283}$ A Tanács 168/2007/EK rendelete az Európai Unió Alapjogi Ügynökségének létrehozásáról [Council Regulation (EC) No. 168/2007 establishing a European Union Agency for Fundamental Rights] HL L 53/1, 2007.2.22. http://fra.europa.eu/sites/default/files/fra_uploads/351-reg_168-2007_hu.pdf (2014. február 25.)

${ }^{284}$ European Union Agency for Fundamental Rights, FRA. http://fra.europa.eu/en 
állásáról. Az egyik jelentés ${ }^{285}$ a gyülölet-büncselekmények alapjogi aspektusára hívja fel a figyelmet, összehasonlító elemzéssel mutatva be a hivatalos adatgyüjtési mechanizmusokat, valamint a hivatalos adatgyüjtés hatókörének kiterjesztési lehetőségeit vizsgálva. A másik, a „Kisebbségek mint a büncselekmények áldozatai” címü jelentés (amely az „EU MIDIS - Középpontban az adatok” címü sorozat 6. részeként jelent meg) a betöréses lopástól a zaklatásig öt büncselekménytípus tekintetében közöl adatokat a válaszadók áldozattá válással kapcsolatos tapasztalatairól. ${ }^{286}$

A FRA álláspontja szerint a gyülölet-büncselekményekkel szembeni hatékonyabb fellépés érdekében az EU-nak és tagállamainak növelniük kell az ilyen bűncselekmények láthatóságát, és fokozni az elkövetők felelősségre vonását. A FRA olyan jogszabályok elfogadását szorgalmazza, amelyek kötelezik a tagállamokat a gyülölet-büncselekményekre vonatkozó statisztikai adatok gyüjtésére és közzétételére. Ezekben az adatbázisokban szerepelnie kellene a lakosság által bejelentett és a hatóságnál nyilvántartásba vett incidensek számának, az elkövetők elleni ítéletek számára vonatkozó adatoknak, az indítékoknak, valamint a kiszabott büntetéseknek. Az Ügynökség álláspontja szerint a bünüldöző szerveknek és az igazságszolgáltatási rendszer egészének kiemelt figyelemmel kell kísérniük az elöítélet által motivált cselekményeket; a jogalkotóknak pedig érdemes lenne mérlegelni a nagyobb büntetési tételek lehetőségét. A bírósági eljárásokat elöítélet indíték esetén nagyobb figyelem kellene, hogy kísérj a annak érdekében, hogy felhívják a figyelmet a gyülöletbüncselekményekre, és nyilvánvalóvá tegyék, hogy az ilyen cselekmények elkövetése szigorúbb büntetést von maga után. ${ }^{287}$

Az Ügynökség jelentésben összegzi egy online felmérés eredményeit, amelyet nyolc európai uniós tagállamban végeztek a zsidóknak a hátrányos megkülönböztetés és gyülölet-büncselekmények terén szerzett tapasztalatairól. ${ }^{288}$ A FRA álláspontja szerint az uniós tagállamoknak biztosítaniuk kell, hogy az antiszemita motivációból elkövetett

\footnotetext{
${ }^{285}$ FRA: Making hate crime visible in the European Union: acknowledging victims' rights, 2012. http://fra.europa.eu/sites/default/files/fra-2012_hate-crime.pdf (2014. március 30.)

${ }^{286}$ FRA: Gyülölet-büncselekmények az Európai Unióban, 2013. http://fra.europa.eu/sites/default/files/frafactsheet_hatecrime_hu_final.pdf (2014. március 30.)

${ }^{287}$ FRA 2013 (Gyülölet-büncselekmények az Európai Unióban), 2.

288 FRA: Discrimination and Hate Crimes against Jews in EU Member States: experiences and perceptions of antisemitism, 2013. http://fra.europa.eu/sites/default/files/fra-2013-discrimination-hatecrime-against-jews-eu-member-states_en.pdf (2014. március 5.)
} 
büncselekmények indítékát a bünüldöző hatóságok megfelelően dokumentálják, és azt a teljes eljárás során figyelembe vegyék. Az Ügynökség arra is rámutatott többek között, hogy az ún. "harmadik fél általi bejelentés" ('third party report') gyakorlata, amelynek keretében civil szervezetek jelentik be az eseteket, illetve segítik az esetek bejelentését a rendőrségen, több veszélyeztetett csoport esetében is növelheti a bejelentési rátát. ${ }^{289}$

Az Európai Parlament és a Tanács 1922/2006/EK rendelete ${ }^{290}$ létrehozta a Nemek Közötti Egyenlőség Európai Intézetét, az EIGE-t, ${ }^{291}$ amelynek feladatait a rendelet 3. cikkében pontosan meghatározták. Az EIGE átfogó céljai a nemek közötti egyenlőség előmozdításához való hozzájárulás és ennek megerősítése, beleértve a nemek közötti esélyegyenlőség érvényesítését valamennyi közösségi politikában és az abból eredő nemzeti politikákban, továbbá a nemen alapuló megkülönböztetés elleni küzdelem és az uniós polgárokban a nemek közötti egyenlőség tudatosításának növelése a közösségi intézményeknek - különösen a Bizottságnak - és a tagállamok hatóságainak nyújtott technikai segítség révén. ${ }^{292} \mathrm{Az}$ Intézet 2010-ben - a müködés megkezdésének évében prioritássá tette a nemi alapú erőszakra vonatkozó kiinduló adatok összegyüjtésének kezdeményezést, és a pekingi mutatók ${ }^{293}$ vonatkozó problématerületének megerősítése érdekében megkezdte a nemi alapú erőszakkal kapcsolatos munkáját, valamint megállapodást kötött a FRA-val, annak érdekében, hogy nemspecifikus szaktudásával és információval támogatást nyújt a FRA részére többek között egy a nőkkel szembeni erőszakról készülő felmérés elkészítéséhez.

\footnotetext{
${ }^{289}$ FRA: Zsidók hátrányos megkülönböztetéssel és gyülölet-büncselekményekkel kapcsolatos tapasztalatai az Európai Unió tagállamaiban, 2013. 3-4. http://fra.europa.eu/sites/default/files/fra-2013-factsheetjewish-people-experiences-discrimination-and-hate-crime-eu_hu.pdf (2014. március 3.)

${ }^{290} \mathrm{Az}$ Európai Parlament és a Tanács 1922/2006/EK rendelete a Nemek Közötti Egyenlöség Európai Intézetének létrehozásáról [Regulation (EC) No 1922/2006 of the European Parliament and of the Council establishing a European Institute for Gender Equality]. HL L 403, 2006.12.30. http://eurlex.europa.eu/LexUriServ/LexUriServ.do?uri=OJ:L:2006:403:0009:0017:HU:PDF (2014. március 31.)

${ }^{291}$ European Institute for Gender Equality, EIGE. http://eige.europa.eu (2014. március 31.)

${ }^{292}$ EIGE: A Nemek Közötti Egyenlöség Európai Intézetének éves jelentése, 2010. http://eige.europa.eu/sites/default/files/AR-HU.pdf (2014. március 31.)

${ }^{293}$ A Pekingben (Kína) 1995-ben megrendezett negyedik Nőügyi Világkonferencián elfogadták a pekingi cselekvési platform néven is ismert „Pekingi nyilatkozat és cselekvési platform az egyenlőségért, a fejlődésért és a békéért" címü dokumentumot. A nők helyzetének javítása és érdekérvényesítési képességük növelése, valamint a nök és a férfiak közötti egyenlőség megvalósítása érdekében a dokumentum stratégiai célkitüzéseket, illetve a nemzetközi közösség a nemzeti kormányok és civil társadalom által végrehajtandó fellépéseket állapít meg. A célkitüzéseket 12 ,problématerület” szerint csoportosították, amelyek közül a nők sérelmére elkövetett erőszak elleni fellépés az egyik terület.
} 


\section{Európai Biztonsági és Együttmüködési Szervezet ${ }^{294}$}

$\mathrm{Az}$ uniós szabályozást tovább árnyalja, hogy például az Európai Biztonsági és Együttmüködési Szervezet (EBESZ) kisebbségvédelemmel kapcsolatos dokumentumai a tagállamokban jogilag kötelezőnek tekintendők, mivel az Unió közös kül- és biztonságpolitikája hivatkozik ezekre. ${ }^{295} \mathrm{Az}$ EBESZ 4/03 számú minisztertanácsi határozatában ${ }^{296}$ felszólítja a tagállamokat, hogy gyüjtsenek adatokat a gyülöletbüncselekményekre vonatkozóan, beleértve a rasszizmus, xenofóbia, diszkrimináció és antiszemitizmus valamennyi erőszakos formájára vonatkozóan. A határozat értelmében az államok vállalják, hogy tájékoztatják az EBESZ-t a meglévő jogszabályi keretekről, és amennyiben szükséges, kikérik az EBESZ szerveinek segítségét a jogszabályok megalkotása és véleményezése során.

A Minisztertanács 621. számú határozatában ${ }^{297}$ a részes államok elkötelezik magukat, hogy a jövőben a gyülölet-büncselekményre vonatkozóan megfelelö adatgyüjtést folytatnak, ami alapján évente jelentést készítenek az Demokratikus Intézmények és Emberi Jogok Hivatalának (DIEJH), ${ }^{298}$ valamint a nyilvánosság számára is hozzáférhetővé teszik e statisztikákat. Emellett a részes államok vállalják, hogy törekszenek a nyomozó hatóság és bírósági szervezet tagjainak továbbképzésére a gyülölet-büncselekmények elleni hatékonyabb fellépés érdekében. A képzések fontosságát a Minisztertanács - többek között - 10/05. számú határozatában ${ }^{299}$ is hangsúlyozta.

Az EBESZ 9/09 számú, a gyülölet-büncselekmények elleni küzdelem tárgyában született minisztertanácsi határozata ${ }^{300}$ felhívja a részes államokat a gyülölet-

\footnotetext{
294 Organization for Security and Co-operation in Europe, OSCE. http://www.osce.org (2014. február 17.) 295 Szajbély-Tóth 2002.

296 OSCE Ministerial Council Decision No. 4/03 Tolerance and non-discrimination, 2 December 2003. http://www.osce.org/mc/19382 (2014. február 18.)

297 OSCE Ministerial Council Decision No. 621 Tolerance and the fight against racism, xenophobia and discrimination, 29 July 2004. http://www.osce.org/pc/35610 (2014. február 18.)

298 OSCE Office for Democratic Institutions and Human Rights, ODIHR. http://www.osce.org/odihr (2014. február 17.)

${ }^{299}$ OSCE Ministerial Council Decision No. 10/05 Tolerance and non-discrimination: promoting mutual respect and understanding, 6 December 2005. http://www.osce.org/mc/17462 (2014. február 18.)

300 OSCE Ministerial Council Decision No. 9/09 Combating hate crimes, 2 December 2009. http://www.osce.org/cio/40695 (2014. február 14.)
} 
büncselekményekre vonatkozó adatok gyüjtésére, valamint a nyilvánosság számára hozzáférhetővé tételére, ilyen adatgyüjtés hiánya esetén pedig a jogrendszerrel összeegyeztethető adatgyüjtés megfontolására, ezzel is hangsúlyozva az adatgyüjtés fontosságát a további intézkedések foganatosítása érdekében. A határozat 2. pontja felhívja a részes államokat a gyülölet-büncselekmények súlyához igazodó, kellő visszatartó erővel rendelkező jogszabályok megalkotására. Tekintettel arra, hogy a gyülölet-büncselekményeknél tapasztalható alacsonyabb jelentési hajlandóság is akadályozza a hatékony fellépést, a határozat további intézkedések bevezetését sürgeti, amellyel ösztönözhetőek, illetve bátoríthatók az áldozatok a feljelentések megtételére. Felismerve a szakmai képzések jelentőségét, a határozat felhívja a részes államokat a jogalkalmazók számára szóló képzési programok kidolgozására és végrehajtására. Emellett a nyomozások kapcsán rámutat a hatékony, gyors nyomozás és a gyülöletbűncselekmények nyilvános elítélésének jelentőségére.

\section{Yogyakarta alapelvek}

2006 novemberében huszonkilenc emberi jogi szervezet és az ENSZ szakértőinek részvételével Yogyakartában (Indonézia) elfogadták a „Yogyakarta alapelvek a nemzetközi emberi jogi szabályok alkalmazásáról a szexuális irányultsággal és nemi identitással kapcsolatban" címü dokumentumot. ${ }^{301}$ A dokumentum huszonkilenc alapelv mentén tekinti át, hogy a nemzetközi emberi jogi normák alapján az államoknak milyen kötelezettségei vannak a szexuális irányultsággal és nemi identitással kapcsolatban. A 2. alapelv rendelkezik az egyenlöséghez és a hátrányos megkülönböztetéstől való mentességhez való jogról. Az 5. alapelv kimondja, hogy „Szexuális irányultságtól és nemi identitástól függetlenül mindenkinek joga van a személyes biztonsághoz, valamint az erőszakkal és a fizikai bántalmazással szembeni állami védelemhez, akár állami tisztségviselö, akár más egyén vagy csoport követi el $a z t t^{\prime \prime}$.

Az alapelvek érvényesülése érdekében az államok vállalják, hogy mindent elkövetnek a megelözés érdekében, valamint azért, hogy védelmet nyújtsanak a szexuális irányultsággal és nemi identitással kapcsolatos erőszakkal és zaklatással szemben,

\footnotetext{
301 Yogyakarta alapelvek: Alapelvek a nemzetközi emberi jogi szabályok alkalmazásáról a szexuális irányultsággal és a nemi identitással kapcsolatban Háttér Társaság (ford.). 2010.. http://ypinaction.org/files/03/30/yogyakarta_hungarian.pdf (2014. február 17.)
} 
illetve minden szükséges jogalkotási intézkedést megtesznek az ilyen típusú erőszak, erőszakkal való fenyegetés, erőszakra való felbujtás, valamint zaklatás megfelelő szankcionálása érdekében. Ezen kívül annak biztosítása érdekében is vállalják a szükséges jogalkotási, közigazgatási egyéb intézkedések megtételét, hogy ne lehessen felhasználni az áldozat szexuális irányultságát vagy nemi identitását az ilyen típusú erőszak igazolására, az elkövető felmentésére vagy a büntetés enyhítésére. Emellett biztosítaniuk kell, hogy az ilyen típusú erőszak eseteit alaposan kivizsgálják, a felelősöket vád alá helyezzék, és megfelelő büntetést szabjanak ki, az áldozatok pedig jogorvoslatban és megfelelő kárenyhítésben részesüljenek.

A dokumentum az állami vállalások körében kitér az szexuális irányultsággal és nemi identitással kapcsolatos erőszakra vonatkozó, tudatosságnövelö kampányok szervezésének kérdéskörére is.

A 9. alapelv - a fogva tartás alatti emberi bánásmódhoz való jog - értelmében az államoknak biztosítaniuk kell, hogy a fogva tartás ne vezessen a védett tulajdonságon alapuló további marginalizációhoz, és ne tegye ki erőszak, bántalmazás, fizikai, lelki vagy szexuális erőszak veszélyének a fogvatartottakat. Az államoknak óvintézkedéseket kell foganatosítaniuk minden olyan fogvatartott esetében, akik szexuális irányultságuk, nemi identitásuk vagy nemi önkifejezésük miatt erőszak veszélyének vannak kitéve.

Összefoglalóan megállapítható, hogy 1945 óta az egyre erősödő kodifikációs törekvések eredményeként számos nemzetközi emberi jogi egyezményt, illetve más dokumentumot fogadtak el, számos állam vált ezek részesévé, illetve a szervezeti felépítés terén is jelentős előrelépések történtek. Annak ellenére, hogy számos dokumentumnak nincs kötelező jogi hatása, ezeket a formális megnyilvánulásokat a nemzetközi közösség által széles körben elfogadott elvek kinyilatkoztatásának tekinthetjük, az elfogadásukat támogató államoktól - így Magyarországtól - is elvárható, hogy az általuk szabadon vállalt politikai kötelezettségeknek megfeleljenek. ${ }^{302} \mathrm{~A}$ nemzetközi emberi jogi normák számos kötelezettséget rónak az államokra mind jogalkotói, mind jogalkalmazói tevékenységük tekintetében, ezen normák értelmében kötelesek védelmet biztosítani a gyülölet és elöítélet által motivált büncselekményekkel szemben. A nemzetközi emberi jogi normák által az államokra rótt kötelezettségek esetében nem feledkezhetünk meg

302 Az ENSZ kisebbségi kézikönyve, Európai Összehasonlító Kisebbségkutatások Közalapítvány, Budapest, 2004. 43. http://www.hunsor.se/dosszie/kissebbsegiKK.pdf (2014. március 5.) 
arról, hogy az emberi jogok gyakorlásának előmozdításából, védelméből és biztosításából fakadó kötelezettségek elsősorban az államok, illetve a kormányok felelőssége, így ezen elvek hatásköre elsősorban Magyarországra hárul. 


\section{Szabályozási és jogalkalmazási nemzetközi kitekintés}

Jelen fejezet célja, hogy a különböző nemzeti mintákat jogalkotás, jogalkalmazás, hivatalos adatgyüjtési rendszer és jó gyakorlatok szempontjából mutassa be és hasonlítsa össze, annak reményében, hogy a vizsgált országok tapasztalatai a gyülöletbüncselekmények hazai szabályozásának és az azokkal kapcsolatos jogalkalmazás hatékonyságát növelő javaslatok megfogalmazásához is hozzájárulnak.

\section{A vizsgálat tárgya}

A gyülölet-büncselekményekkel kapcsolatos jogszabályok elfogadása az elsődleges lépés a probléma hatékony kezelése érdekében. Számos nemzetközi szervezet vázol fel lehetséges irányokat ajánlásaiban a hatékony szabályozás kialakítása érdekében, ösztönözve az államokat a történelmi és társadalmi kontextus figyelembevételével történő büntető jogalkotásra. ${ }^{303}$

Amint azt a korábbi fejezete tárgyalták, a jogalkotónak két alapvető kérdésben kell döntenie, ha a szabályozás megalkotása mellett határoz. Elöször is azt kell meghatározni, hogy milyen formában szabályozza a gyülölet-büncselekményeket: külön tényállást hoz-e létre; minősítő körülményként; általános részi büntetési tételt emelő rendelkezésként; vagy súlyosító körülményként szabályozza az előítélet-motivációt.

Másodszor szükség van a védett tulajdonságok meghatározására. Egy nem kellően átgondolt szabályozás akár a gyakran áldozattá váló csoportok kirekesztéséhez vagy akár túl tág védett csoporti kör kialakításához is vezethet. A jogalkotó ennek megfelelően két módszer közül választhat: vagy zárt végü listát hoz létre, amellyel pontosan meghatározza a védelemben részesülő csoportokat, szem előtt tartva az adott ország történelmi és társadalmi sajátosságait és az előítélet-motiválta bűncselekményekkel szembeni fellépés tapasztalatait (leggyakoribb áldozati csoportok

\footnotetext{
${ }^{303}$ Lsd. pl.: Az Európa Tanács Miniszteri Bizottságának CM/REC(2010)5. sz. ajánlása a tagállamok felé a szexuális irányultság, illetve nemi identitás alapján történö diszkrimináció leküzdését célzó intézkedésekröl (Recommendation CM/Rec(2010)5 of the Committee of Ministers to member states on measures to combat discrimination on grounds of sexual orientation or gender identity) 1081st meeting of the Ministers' Deputies, 2010. vagy European Commission against Racism and Intolerance, ECRI 7. sz. általános ajánlása: A rasszizmus és a faji megkülönböztetés elleni küzdelem a nemzeti jogalkotásban (ECRI General Policy Recommendation No. 7: National Legislation to Combat Racism and Racial Discrimination) CRI(2003)8, 2002.
} 
meghatározásával); vagy nyílt végü listát alkalmaz, akként, hogy a tipikus védett tulajdonságok mellé elhelyez egy feltételt - mint például egyéb társadalmi csoportok, a lakosság egyes csoportjai -, amellyel lényegében a jogalkalmazóra bízza a védett tulajdonságok körének kialakítását. ${ }^{304}$

Álláspontom szerint ez a két kérdéskör képezi azt a minimumot, amelyben a jogalkotónak szükségszerüen állást kell foglalnia a szabályozás kialakítása során. Ehhez persze egyéb meghatározandó szempontok is hozzáadhatók: így a gyülöletvezéreltség mint motívum meghatározására; az elkövetői tévedés tényállásban értékelésére; illetve a bizonyítottság szempontjainak meghatározására ${ }^{305}$ is vállalkozhat a jogalkotó - bár ezek nem szükségszerüen jogalkotási kérdések. A motívum értékelése javarészt jogalkalmazói kérdés és nem is jellemző, hogy a büntető törvénykönyv definiálja a gyülölet- vagy elöítélet-motivációt. A motívum és tévedés kapcsán pedig megjegyezendő, hogy - a magyar büntetőjog alapján - a motívum alapjául szolgáló tényekben való tévedés irreleváns. ${ }^{306}$ Így a sértettnek nem kell az adott csoporthoz tartoznia elég, ha az elkövető az adott csoporthoz tartozónak véli. Természetesen, ha a jogrendszer sajátosságai vagy egyéb indokok alapján a jogalkotó szükségesnek véli, akkor a tényállásban kihangsúlyozható. Végül a bizonyítottság kérdésköre komplexitásából és eljárásjogi jellegéből adódóan szintén inkább a jogalkalmazásra tartozó kérdéskör, így például nyomozati protokollokban emelendőek ki azon faktorok, amelyek a gyülölet-büncselekmény gyanúját támasztják alá.

A második legfontosabb lépés annak biztosítása, hogy a jogalkalmazók, így a rendőrök, ügyészek és bírák kellően képzettek és kellően felszereltek a hatékony fellépés érdekében. A gyülölet-büncselekmények elleni fellépés terén a jogszabályi hiányosságoknál is súlyosabb problémát jelent, ha a jogalkalmazó szervek, elsősorban a rendőrség, nem képes a vonatkozó jogszabályokat a gyakorlatban hatékonyan alkalmazni. A gyülölet-büncselekmények sajátosságai (elsősorban a motiváció bizonyíthatóságának nehézsége és az áldozati csoportok fokozott érzékenysége) számos ország rendőrségét arra vezették, hogy külön irányelveket fogadjanak el a gyülöletbüncselekményekkel kapcsolatos nyomozásokra. Gyakorlati tapasztalatok azt mutatják,

304 GYEM Javaslatok az új Büntetö Törvénykönyv... 2012, 3. ill. EBESZ/DIEJH Hate Crime Laws... 2009, 39.

305 Novoszádek-Rácz 2009, 3-4. és 63-80.

${ }^{306}$ Hollán-Kis 2008, 137. 
hogy az ilyen nyomozati protokollok akkor igazán hatékonyak, ha nem csupán az általános megállapításokat tartalmaznak, hanem konkrét segítséget nyújtanak az ilyen ügyekben folytatandó nyomozási vagy kihallgatási munkában. Emellett nagyban elősegítheti a hatékonyságot, ha az anyag kidolgozásába a civil szervezeteket is bevonják, és áttekintik az ilyen irányú külföldi jó példákat. Szintén fontos, hogy a protokoll hivatalos formát öltsön, és így a létezése a rendőrségen belül is széles körben ismertté váljon, valamint számon kérhetővé váljon. Természetesen ebben az esetben is szem előtt kell tartani a nemzeti sajátosságokat és a gyakorlati szempontokat. A rendőrök számára készült már egyébként is rengeteg útmutató mellett „elveszhetnek” ezek az útmutatók, így adott esetben más eszközökre is szükség van a fellépés hatékonyságának biztosítása érdekében.

A rendőrségnek szóló protokoll mellett hasznos lehet egy kifejezetten a bizonyítási eljárás nehézségei terén eligazítást nyújtó ügyészségi protokoll elfogadása is. Egy ilyen protokollt az EBESZ/DIEJH keretei között dolgoztak ki, ${ }^{307}$ amely kifejezetten jó alap lehet a részes államok számára. Az ítélkezési gyakorlat terén mutatkozó ellentmondások, így különösen a védett csoportok köre, az elöítéletes indíték mint súlyosító körülmény figyelembe vételének kötelezettsége kapcsán különböző ítélkezési útmutatók kibocsátása nyújthat segítséget.

A tapasztalatok azt mutatják, hogy a gyülölet-büncselekmények nyomozása speciális szakértelmet igényel, hiszen ezek a büncselekmények kriminalisztikai szempontból összetett megítélésűek, felderítésük és bizonyításuk a legtöbbször igen komoly feladat. ${ }^{308}$ Így erre a feladatra külön felkészített és folyamatosan képzett nyomozók vagy egy speciális nyomozóegység biztosíthatják a leghatékonyabb fellépést. Az elöítélet-motiválta büncselekmények nyomozására eltérő intézményi megoldások alakultak ki: vannak országok, ahol rendőrségi összekötőt alkalmaznak; vannak, ahol külön, helyi szintü gyülölet-büncselekmények elleni nyomozati egységeket hoztak létre; vannak, amelyek közös egység hoznak létre vagy külön nyomozó jelölnek ki nagyobb

\footnotetext{
${ }^{307}$ EBESZ/DIEJH Prosecuting Hate Crimes... 2014.

308 Amint arra Budapest Rendőrfőkapitánya is rámutatott a GYEM gyülölet-büncselekmények nyomozásával kapcsolatos levelére írt válaszában: „A gyülölet-büncselekmények nyomozási anomáliái kapcsán írt felvetéseik vonatkozásában elmondható, hogy a felmerült problémák jelentős részéért ezen büncselekményi kategória kriminalisztikai jellemzői - bizonyításhoz szükséges tényállási elemek feltárási, nyomozásmetodikai nehézsége - a felelősek, és azon körülmény, hogy sokszor a bizonyítandó tényállási elemekről kevés releváns adat áll rendelkezésre.” Budapest Rendőrfőkapitánya, szám: 0100048605/2/2012.ált.
} 
közigazgatási területet (pl. tartományt, megyét) átfogva; illetve vannak olyan országok is, ahol bár a nyomozás megmarad helyi hatáskörnek, a helyi nyomozóknak az ilyen ügyekben kötelességük együttmüködni egy központi támogató egység speciálisan képzett munkatársaival; de találkozhatunk az ezeket ötvöző vegyes rendszerekkel is; végül van, ahol helyi hatáskörben marad, és nem szentelnek kiemelt figyelmet az elöítélet-vezérelte büncselekményeknek hatásköri szempontból.

A jogalkotási és jogalkalmazási kérdések mellett a gyülölet-büncselekmények elterjedtségére és hatósági kezelésére vonatkozó megbízható adatok összegyüjtése, elemzése és nyilvánosságra hozatala alapvető jelentőségű mind a széles társadalom, mind az érintett hatóságok tudatformálásához. A megbízható adatgyüjtési rendszer elősegíti a probléma teljes megértését és a hatékony fellépést. A megbízható adatok kulcsfontosságúak a gyülölet-büncselekményekkel kapcsolatos szakpolitikák fejlesztéséhez és segítik a lobbi tevékenységet végző és áldozatok segítésével foglalkozó szervezetek munkáját. ${ }^{309}$

Nemzetközi szinten nagy különbségek tapasztalhatók az adatgyüjtési módszerek, az adatgyüjtés hatékonysága és így a hivatalos statisztikák terén. A részes államok által az EBESZ számára rendelkezésre bocsátott gyűlölet-bűncselekmény statisztikák alapján az elmúlt három év adatai a következők néhány ország esetében példálózó jelleggel: ${ }^{310}$

\begin{tabular}{|c|c|c|c|}
\hline Ország311 & $\begin{array}{l}\text { Rögzített esetek } \\
\text { száma-2012 }\end{array}$ & $\begin{array}{l}\text { Rögzített esetek } \\
\text { száma - } 2011\end{array}$ & $\begin{array}{l}\text { Rögzített esetek } \\
\text { száma - 2010 }\end{array}$ \\
\hline Ausztria & 91 & 59 & 101 \\
\hline Belgium & 615 & 1152 & 815 \\
\hline Dánia & 320 & 384 & 334 \\
\hline Egyesültt Királyság & 47676 & 50688 & 53946 \\
\hline Horvátország & 57 & 34 & 32 \\
\hline Kanada & Nincs adat & 1322 & 1401 \\
\hline Magyarország & 38 & 37 & 19 \\
\hline
\end{tabular}

${ }^{309}$ CEJI - Zsidó Hozzájárulás a Befogadó Európához (A Jewish Contribution to an Inclusive Europe): Tegyünk láthatóvá a gyülölet-büncselekményeket. Nézzünk szembe a tényekkel! Útmutató a gyülöletbüncselekmények és elöitélet motiválta incidensek monitorozásához. 2012. november. http://www.ceji.org/media/facing-facts-guidelines-hungarian.pdf (2014. Június 7.)

${ }^{310}$ EBESZ/DIEJH: Hate Crime Monitoring. http://hatecrime.osce.org/what-do-we-know

${ }^{311} \mathrm{Az}$ adatok több esetben a gyülöletbeszéddel/gyülöletre uszítással vagy izgatással kapcsolatos eseteket s tartalmazzák. 


\begin{tabular}{|l|l|l|l|}
\hline Németország & 4514 & 4040 & 3770 \\
\hline Norvégia & 216 & 218 & 242 \\
\hline Szlovákia & 102 & 242 & Nincs adat \\
\hline
\end{tabular}

Ezen számokkal szemben az áldozattá válásról szóló kutatások egészen más adatokat mutatnak. Az Európai Unió 2008. évi felmérése a kisebbségekről és a hátrányos megkülönböztetésről (EU-MIDIS) ${ }^{312}$ azt állapította meg, hogy az etnikai és bevándorlói csoportba tartozó személyek esetében négy megkérdezettből több mint egy azt állította, hogy a felmérést megelőző 12 hónapban rasszista indíttatású, személy elleni büncselekmény (testi sértés, fenyegetés, súlyos zaklatás) érte. A kutatás eredményei azt mutatják, hogy az áldozatok (és szemtanúk) nem szívesen jelentik ezeket a büncselekményeket. Az adatgyüjtési rendszerben tapasztalható anomáliák oka lehet még: félreminősítés, illetve ha az adatok „elvesznek” az adatgyüjtési rendszerben. Az elöítélet-motivációt fel nem ismerve más, a gyülölet-büncselekmény tényállásának alapját képező tényállás miatt indul nyomozás, és születik olykor ítélet (például testi sértés, garázdaság). Emellett ahol nem kezelik külön a gyülölet-büncselekményekre vonatkozó adatokat, ott szintén nem jelennek meg ezen esetek. Így például a magyar szabályozásban emberölés minősített esetét képező aljas indok magában foglalja az előítélet-motivációt, és a statisztikában az aljas indok átfogó kategóriájába olvad bele. Erre tekintettel is fontos a külön szabályozás megalkotása, amely megkönnyíti a hatékony adatgyüjtési rendszer kiépítését.

A FRA álláspontja szerint az EU tagállamoknak olyan jogszabályokat kellene elfogadniuk, amelyekben kötelezik magukat a gyülölet-bűncselekményekre vonatkozó statisztikai adatok gyüjtésére és közzétételére, és amelyben abszolút minimumként szerepelnie kellene a lakosság által bejelentett és a hatóságnál nyilvántartásba vett incidensek számának, az elkövetők elleni ítéletek számára vonatkozó adatoknak, illetve azoknak az indítékoknak, amelyeken a hátrányos megkülönböztetés alapult, valamint a kiszabott büntetéseknek. Figyelembe véve az EBESZ/DIEJH éves jelentését ezeknek a minimum feltételeknek igen kevés állam adatgyüjtési rendszere felel meg. Ami az adatgyüjtő szerveket illeti, 35 tagállam adatai alapján az alábbi szervek gyüjtik a

${ }^{312}$ FRA Gyülölet-büncselekmények az Európai Unióban ... 2013. 
gyülölet-büncselekményekre vonatkozó adatokat: ${ }^{313}$ rendészeti szervek (26 országban); ügyészség (27 ország); belügyekért felelős minisztérium (23 ország); igazságügyért felelős minisztérium (21 ország); statisztikai hivatal (11 ország); hírszerzési szervek (5 ország); egyéb intézmények (19 ország).

Az EBESZ harmincöt tagállama által biztosított adatok alapján az alábbiak szerint alakulnak a védett csoportok: az etnikai vagy nemzeti hovatartozás 35 ; a vallás 34 ; faj illetve bőrszín 35; szexuális irányultság 21; állampolgárság 16; nem 17; nyelv 14; fogyatékosság 13; nemi identitás 9; egyéb kategória 13 tagállam szabályozásában szerepel. ${ }^{314}$

A gyülölet-büncselekményekre vonatkozó adatgyüjtés elengedhetetlen e büncselekmények természetének és elterjedtségének megértéséhez, az áldozatvédelmi válaszok kialakításához, a megelőzéshez, az intézkedések hatékonyságának méréséhez. Ennek megfelelően az EBESZ részes államok a 13/06. számú minisztertanácsi határozatban ${ }^{315}$ hangot is adtak azon felismerésnek, hogy a hatékony adatgyüjtés érdekében elengedhetetlen a stratégiai tervezés és a megfelelő forráselosztás. A gyülölet-büncselekményekkel kapcsolatban mára már világossá vált, hogy e büncselekményekkel kapcsolatban rendkívül alacsony a jelentési hajlandóság, amelynek számos oka van, így például: a reviktimizációtól - az áldozatoknak a nyomozati eljárás során újra áldozattá válásától való félelem; a viktimizáció által okozott megalázottság és szégyen érzete; az áldozatok azzal kapcsolatos kételyei, hogy az eljárás hogyan segítene a helyzetükön; a rendőrségbe vetett bizalom hiánya; egyes áldozati csoportok esetében a nyelvi akadályok; hivatalos dokumentumokkal nem rendelkező áldozatok esetében a kiutasítástól való félelem; LMBT áldozatok esetében a nemi identitás, szexuális irányultság nyilvánosságra kerülésétől való félelem; végül az áldozatok sok esetben nem is tudják, hogy a sérelmükre elkövetett cselekmény büncselekményt valósít meg. ${ }^{316}$

\footnotetext{
${ }^{313}$ EBESZ/DIEJH Hate Criemes in the OSCE Region... 2012, 17-18.

${ }^{314}$ Uo. 18.

315 OSCE Ministerial Council, Decision No. 13/06, Combating Intolerance and Discrimination and Promoting Mutual Respect and Understanding, Brussels, 5 December 2006. http://www.osce.org/mc/23114?download=true (2015. március 7.)

${ }^{316}$ Bővebben lásd Paul Iganski: Racist Violence in Europe, Brüsszel, 2011. 16. http://enarireland.org/wpcontent/uploads/2013/07/Racist-Violence-in-Europe.pdf (2015. március 7.) ill. EBESZ/DIEJH: Hate Crime Data-Collection and Monitoring Mechanisms. A Practical Guide. Varsó, 2014. 5. http://www.osce.org/odihr/datacollectionguide?download=true (2015. március 7.)
} 
Az adatgyüjtés kapcsán elsődleges lépés egy közös, átfogó és egyszerü fogalom kialakítása, amelyet mind a rendőrség, mind az ügyészség, mind a bíróságok alkalmaznak és az áldozatok számára is érthető. Egy ilyen fogalom lehetővé tenné az igazságszolgáltatás valamennyi szintjén az egységes adatgyüjtés és az adatok összehasonlítását. ${ }^{317}$ Németországban például annak ellenére, hogy nincsenek külön gyülölet-büncselekményekkel kapcsolatos rendelkezések a büntető törvénykönyvben, létrehoztak egy egységes adatgyüjtési fogalmat, a politikai indíttatású büncselekményeket.

Az adatgyüjtési fogalom megalkotását követően arról kell határozni, hogy milyen feltételek mellett rögzítik a cselekményt gyülölet-büncselekményként. Vannak olyan objektív körülmények, amelyek az elöítélet motivációra utalnak. ${ }^{318} \mathrm{Ha}$ az elkövető például rasszista kijelentéseket tesz a büncselekmény elkövetése során, akkor az elöítélet motivációra enged következtetni. Mindazonáltal vannak esetek, amikor az elöítélet motiváció nem egyértelmü az eljárás kezdeti szakaszában. De ez a probléma is áthidalható adatgyüjtési szempontból például egy „lehetséges gyülölet-büncselekmény” kategória megalkotásával és a végleges minősítés az eljárás későbbi szakaszában is rögzíthető. Ha már az eljárás kezdeti szakaszában rögzítik a lehetséges motivációt, akkor kisebb az esélye a későbbi félreminősítéseknek. Egy másik megoldás, amit Angliában alkalmaznak, hogy gyülölet-büncselekményként kell rögzíteni minden olyan bűncselekményt, amely az áldozat percepciója alapján előítélet által motivált. Mindezek fényében a leghatékonyabb megoldás, ha a lehető legtágabb megközelítést alkalmazzák a kezdeti besorolás során. ${ }^{319}$

A nyilvántartott büncselekmény kategóriák szempontjából a leghatékonyabb megoldás, ha a gyülölet-büncselekményekkel kapcsolatos adatgyüjtést a használt kategóriákhoz igazítva végzik. Ezáltal lehetővé válik a büncselekmények közötti összehasonlítás és kevésbé forrásigényes megoldás. Alapvetően a büntető törvénykönyvbe foglalt büncselekményekhez kell igazodnia az adatgyüjtésnek, de figyelemmel kell lennie arra,

\footnotetext{
${ }^{317}$ EESZ/DIEJH Hate rime Data-Collection ... 2014. 12-13.

${ }^{318}$ Lásd IACP Responding to Hate Crimes... 7.

${ }^{319}$ EESZ/DIEJH Hate rime Data-Collection ... 2014. 15-16.
} 
hogy ha például az emberölés tényállásában nem is szerepel az elöítélet motiváció mint minősített eset, akkor is megjelenjen az adatgyüjtésben e motiváció. ${ }^{320}$

Ahol a források és a jogszabályok lehetővé teszik, mindenképp indokolt a legszélesebb körü adatgyüjtést végezni, így például ajánlott az áldozatra és elkövetőre vonatkozó demográfiai adatok, az elkövetés helyének vagy akár a többszörös motiváció tényének ${ }^{321}$ rögzítése. Fontos az is - a későbbiekben részletezett német tapasztalatok alapján - hogy a gyüjtött adatokat más olyan kategóriáktól elkülönülten rögzítsék, mint például extrémizmus vagy politikai motiváció. Kétségtelen, hogy ezek sok esetben összefüggő jelenségek, de ha például extrémizmus alapján gyüjtik az adatokat, akkor egy olyan elkövető esetén, aki egyetlen szélsőséges csoporthoz sem köthető a gyülöletbüncselekmény akár rögzítetlenül maradhat. ${ }^{322}$

Mindemellett a hatékony adatgyüjtési rendszer megköveteli: az olyan egyértelmü jelentési és ellenőrzési rendszer meglétét, amely iránymutatásokkal is alátámasztott; rendőrségi képzések szervezését a rendszer hiánytalan megismerése és megértése érdekében; a rendszer folyamatos felülvizsgálatát az akadályok elhárítása érdekében; valamint az átláthatóságot mind az állami szervek egymás közötti kapcsolatában, mind az állampolgárok felé az adatok rendszeres és teljes nyilvánosságra hozatalával a közvélemény és a védett csoportok tájékoztatása érdekében. Mindezek érvényre juttatása érdekében érdemes egy egységesített bejelentési nyomtatványt kialakítani, amely a rendőrség munkáját és a bejelentéseket is megkönnyíti. Végül a rendőrség számára készült iránymutatások, képzések is kiemelt fontossággal bírnak, akárcsak az adatgyüjtéssel kapcsolatos felelősség tisztázása. ${ }^{323}$

Az adatgyüjtés önmagában persze nem oldja meg a fennálló problémákat, de fontos része egy komplex megközelítésnek. A hatékony adatgyüjtés mellett szükség van például jogalkotási lépésekre, képzésekre, az antidiszkriminációs jog fejlesztésére, helyi közösséget és a teljes társadalmat célzó különböző programokra és hatékony áldozatvédelmi rendszerre.

\footnotetext{
${ }^{320}$ Uo. $16-17$.

${ }^{321}$ Előfordulhat, hogy egy antiszemita támadás egyszerre faji és vallási alapú támadás.

${ }^{322}$ EESZ/DIEJH Hate rime Data-Collection ... 2014. 17-19.

${ }^{323}$ Uo. $20-25$.
} 
A tapasztalatok azt mutatják, hogy a civil szervezetek nagyban hozzájárulhatnak az állami szervek munkájának hatékonyságához a gyülölet-büncselekményekkel szembeni fellépés terén. ${ }^{324}$ Egyre több innovatív, ígéretes és eredményes példát találhatunk például a civil szervezetek és rendészeti szervek együttmüködésére. A leggyakoribbi területek, ahol a civil szervezetek és a rendészeti szervek együttmüködésre lépnek: figyelem felhívó kampányok és kapacitásépítés; feljelentéseket (bejelentéseket) ösztönző és áldozattámogatást szolgáló kezdeményezések; monitoring és adatgyüjtő stratégiák fejlesztése; gyülöletincidensek ${ }^{325}$ megelőzése; a szabályozás és szakpolitikák érvényre juttatása. ${ }^{326}$ Emellett remek példáként találhatunk rendőrségen belüli tudatosságnövelő kampányokra, képzési programokra vagy éppen a gyülöletbüncselekményekkel szembeni külön nyomozócsoport keretében történő fellépésre.

\section{A vizsgált országok}

A továbbiakban Anglia, Dánia, Kanada és Németország gyülölet-büncselekményekkel kapcsolatos szabályozását és gyakorlatát vizsgálom. A választást minden ország esetében más indokolja.

Anglia gyülölet-büncselekményekkel kapcsolatos tevékenységének vizsgálata nem is volt kérdéses, mivel Anglia közismerten az egyik legátfogóbb gyülöletbűncselekményekre vonatkozó szabályozással, átgondolt rendészeti szervezetrendszerrel, egyre szélesebb körü adatgyüjtési rendszerrel és számos jó gyakorlattal rendelkező állam.

Dánia a gyülölet-büncselekmények üldözése terén nagy lépéseket tett az elmúlt években a „Tracing and Tackling Hate Crimes Against LGBTs” elnevezésű uniós projekt keretében. A kilenc uniós tagállamot magában foglaló projektben kiemelt partner volt a koppenhágai rendőrség, amely nem csak a képzési program kialakításában, de a gyülölet-bűncselekményekkel kapcsolatos kutatásokban és megelőző és figyelemfelhívó

\footnotetext{
324 Így például az Európa Tanács emberi jogok biztosa magyarországi látogatását követően megjelent jelentésében azt javasolja, hogy a rendőröknek, ügyészeknek és bíráknak a nemzetközi és hazai civil szervezetekkel együttmüködve szervezzenek képzéseket. Report by Nils Muižnieks Commissioner for Human Rights 2014, 24.

325 Gyülölet incidens, amely még nem képez büncselekményt és amelyet az áldozat más személy úgy észlel, hogy elöítélet vagy gyülölet által motivált.

${ }^{326}$ International Lesbian, Gay, Bisexual, Trans and Intersex Association (ILGA): Joining Forces to Combat Homophobic and Transphobic Hate Crime: Cooperation between Police Forces and LGBT Organizations in Europe. 2010, 7.
} 
kampányokban is aktívan részt vett. Ezért Dánia esetében föleg a (figyelemfelhívás és adatgyüjtés területén kialakult) jó gyakorlatok indokolták a kiválasztást.

Kanada esetében szintén több szempontból indokolt a gyülölet-büncselekményekkel szembeni fellépés eszközeinek a vizsgálata. Kanada egyre sokszínübb országgá válik, 2011-ben már a kanadaiak 19\%-a sorolta magát valamilyen kisebbségi csoporthoz. Vallási nézetet illetően pedig 7,2\% vallotta magát a keresztény vallástól eltérő vallás követőjének. Emellett a lakosság 4,3\%-a valamely őslakos csoporthoz tartozik. ${ }^{327} \mathrm{~A}$ demográfiai változásokkal párhuzamosan az elöítéletes magatartások is növekvő tendenciát mutatnak az országban. ${ }^{328}$ Ennek következtében a gyülöletbüncselekményekkel szembeni fellépés is határozottabb válaszokat igényel. Ezért például a jogalkalmazás területén számos példaértékü megoldás született, amelyek egy részét kanadai kutatásim során volt lehetőségem közelebbről is megvizsgálni.

Végül Németország esetében a gyülöletmotiválta erőszak területén szerzett történelmi tapasztalataira tekintettel az átalagostól egy határozottan eltérő megközelítés alakult ki a gyülölet-büncselekményekre vonatkozóan. Ennek eredményeképp a gyülöletbüncselekmények - mint később kifejtésre kerül - szorosan összefonódtak a jobboldali szélsőséges cselekményekkel. ${ }^{329}$

\section{Jogalkotás}

Dánia és Kanada súlyosító körülményként szabályozza a gyülölet-büncselekményeket, emellett Kanadában egy minősített eset is szerepel a Btk.-ban. Németország nem alakított ki külön szabályozást, míg Anglia a vegyes szabályozás mellett döntött. A védett csoportok vonatkozásában hasonló tendencia mutatkozik: Dánia és Kanada nyílt listát alkalmaz, Anglia szintén vegyes megközelítést alkalmaz. Mivel Németország nem alkalmaz külön szabályozást ezért a védett csoportok kérdése fel sem merül a büntető

${ }^{327}$ National Household Survey, 2011. http://www12.statcan.gc.ca/nhs-enm/index-eng.cfm (2014. október 30.)

${ }^{328}$ Lásd Godfred Chongatera: „Hate-Crime Victimization and Fear of Hate Crime Among Racially Visible People in Canada: The Role of Income as a Mediationg Factor" Journal of Immigrant and Refugee Studies, Vol. 11. 2013, 44-64. és Jeffrey Ian Ross: „Hate Crime in Canada: Growing Pains with New Legislation" in Mark S. Hamm (szerk.): Hate Crime: International Perspectives on Causes and Control. Cincinnati: Anderson Publising, 1994, 166.

${ }^{329}$ Alke Glet: The German Hate Crime Concept: An Account of the Classification and Registration of Bias-Motivated Offences and the Implementation of the Hate Crime Model into Germany's Law $\begin{array}{lllll}\text { Enforcement, Internet Journal of Criminology, } & 2009, & 3 .\end{array}$ http://www.internetjournalofcriminology.com/Glet_German_Hate_Crime_Concept_Nov_09.pdf (2014. november 5.) 
jogszabályok vonatkozásában. Azonban a később ismertetett adatgyüjtést tekintve rendelkezik a védett csoportokról, amely azonban a rendszer speciális jellegéből adódóan eltér a bevett módszerektől.

A dán büntető törvénykönyv 81 . szakasz 6 . pontja ${ }^{330}$ a büntetéskiszabási rendelkezések (Straffens fastsættelse) $^{331}$ között - többek között a visszaesőként és különös kegyetlenséggel történő elkövetés mellett - rendelkezik az elöítélet-motiválta büncselekményekről. A nyílt végü listában a sértett etnikai származása, vallási hovatartozása, szexuális irányultsága mellett az “egyéb” kategóriával enged szabad utat a jogalkalmazónak a védett tulajdonságok meghatározására.

Kanada mintegy 40 éves múltra tekint vissza a gyülöletpropaganda és gyülöletbüncselekmények elleni fellépés terén. A szabályozás szüksége az igazságügyi minisztérium gyülöletpropagandáért felelős külön-bizottságának 1965-ös jelentése kapcsán merült fel. ${ }^{332} \mathrm{~A}$ bizottság munkája során arra törekedett, hogy érvényre jutassa a faji megkülönböztetés minden formájának kiküszöböléséről szóló nemzetközi egyezmény, ${ }^{333}$ a népirtás büntettének megelőzéséről és büntetéséről szóló nemzetközi egyezmény $^{334}$ és a kanadai Bill of Rights elöírásait. A bizottság tevékenysége eredményeként módosították először a kanadai büntető törvénykönyvet, először csak a gyülöletbeszéd kapcsán.

A kanadai büntető törvénykönyvbe végül egy 1995-ös törvénymódosító javaslat 335 eredményeként került be a 718.2. szakasz a) pont (i) alpontja, ${ }^{336}$ amely 2006 szeptemberében lépett hatályba. A dán szabályozáshoz hasonlóan, a büntetéskiszabás céljai és alapelvei című fejezetben található szabály alapján a bíróságnak a

330 Legislationline - a dán Btk. releváns rendelkezéseinek kivonata http://www.legislationline.org/documents/action/popup/id/9032 (2014. június 9.)

${ }^{331}$ Lásd dán Btk. https://www.retsinformation.dk/Forms/R0710.aspx?id=121398\#Kap11 (2014. június 9.)

332 Lásd bővebben Cohen Bizottságra Philip Rosen: Hate propaganda. 2000. http://www.parl.gc.ca/Content/LOP/researchpublications/856-e.htm (2014. október 5.)

333 Nemzetközi egyezmény a faji alapú hátrányos megkülönböztetés valamennyi formájának kiküszöböléséröl (International Convention on the Elimination of All Forms of Racial Discrimination) U.N.T.S. No. 9464, Vol. 660, 1969, 212. (Magyarországon kihirdette az 1969. évi 8. törvényerejü rendelet.)

334 Nemzetközi egyezmény a népirtás büntettének megelőzéséről és büntetéséről (Convention on the Prevention and Punishment of the Crime of Genocide) U.N.T.S. No 1020, Vol. 78, 1951, 277. (Magyarországon kihirdette az 1955. évi 16. törvényerejü rendelet.)

335 Lásd „Bill C-41” címü törvénymódosító javaslat. http://library.lawsociety.sk.ca/inmagicgenie/documentfolder/AC1730.pdf (2014. szeptember 7.)

${ }_{336}$ Btk. 718.2. szakasz a) pont (i) alpont. http://laws-lois.justice.gc.ca/eng/acts/C-46/ (2014. szeptember 10.) 
büntetéskiszabás során súlyosító körülményként kell értékelnie, ha a cselekményt faji, nemzeti vagy etnikai származás, nyelv, bőrszín, vallás, nem, kor, szellemi vagy fizikai fogyatékosság, szexuális irányultság vagy más hasonló körülményen alapuló elöítélet vagy gyülölet motiválja. ${ }^{337}$ Tehát a kanadai Btk. szintén nyílt végü listát alkalmazva, súlyosító körülményként szabályozza a gyülölet-büncselekményeket. A súlyosító körülmény mellett a Btk. 430. szakasz (4.1.) bekezdése rendelkezik a vallási tisztelet tárgya elleni rongálásról, amely értelmében a rongálás minősített esetét képezi, ha a cselekményt vallási, faji, bőrszín, nemzeti vagy etnikai származáson alapuló előítélet vagy gyülölet motiválta. Sui gerenis tényállást ezen kívül a törvénykönyv nem tartalmaz, csupán a gyülöletbeszéd kapcsán. Sok nemzeti szabályozástól eltérően nem külön vagy más minősítő körülmény részeként (például aljas indok) szerepel az elöítélet motiváció az emberölés büntette kapcsán, hanem a 718.2. szakasz a) pont (i) alpontja alkalmazandó előítélet-motiválta büncselekmény esetében , ahogy tette ezt a bíróság az R. kontra Miloszewski ügyben ${ }^{338}$ is. A nevezett ügyben öt elkövető egy hindu templom elkerített parkolójába tört be, hogy az ott található autókat megrongálja. Az elkövetők végül rátámadtak a templom gondnokára is, aki a bántalmazás okozta sérüléseibe belehalt. A bíróság megállapította, hogy kétséget kizáróan bizonyítást nyert az elöítélet motiváció. A motivációt - más körülmények mellett, mint például elkövetés helye, elkövetők csoporttagsága - alátámasztotta az egyik elkövető vallomása is. Eszerint a támadásban egy szkinhead csoporthoz - amelyhez a másik négy elkövető is tartozott való tagfelvétele érdekében vett részt. A bíróság a Btk. 718.2. szakasz (a) pont (i) alpont alapján súlyosító körülményként vette figyelembe az elöítélet motivációt és 17-25 év közötti szabadságvesztés büntetéseket szabott ki.

Az elöítélet-motiváció bírói gyakorlata kapcsán kiemelendő, hogy a kanadai jog is megköveteli annak elsődlegességét. ${ }^{339} \mathrm{Az}$ elsődleges vezérlő motívumának a közösséghez való tartozás miatti ellenséges érzületnek kell lennie. Ez a motívum pedig nem eseti jelleggel, hanem állandó jelleggel van jelen az elkövető tudatában, annak nézetrendszerében gyökerezik. Ahol az elöítélet csupán másodlagos, esetleges, ott nem

337 Lásd Ministry of Attorney General: End Hate Crime: B.C. Hate Crime Team Roles and Responsabilities. http://www.ag.gov.bc.ca/prosecution-service/pdf/EndHateCrimes_booklet.pdf (2014. szeptember 10.)

${ }^{338}$ R. v. Miloszewski [1999], B.C.J. No. 2710 (Prov. Ct.), 1999. november 16.

${ }^{339}$ Lásd például Julia Sandler: Hate Motivation as an Aggravating Factor on Sentence: An Overview of the Legal Landscape, 2010. http://www.law.utoronto.ca/documents/conferences2/CombatingHatred10_Sandler.pdf (2014. szeptember 10.) 
alkalmazható a súlyosító körülmény. A $R$. kontra Baxter ügyben ${ }^{340}$ is erre mutatott rá a bíróság. Az ügyben a kisebbségi csoporthoz tartozó elkövető bántalmazta szintén kisebbségi csoporthoz tartozó barátnőjét rasszista sértések kíséretében. A bíróság kimondta, hogy a rasszizmus ugyan jelen volt a cselekmény elkövetésekor, de nem motiválta a cselekményt.

Az ismertetett országok közül Anglia rendelkezik a legátfogóbb szabályozással. A jogi szabályozás három pilléren áll az angol jogrendszerben: a rasszista és vallási elöítélet tanúsításával, illetve ilyen motivációból elkövetett testi sértés, rongálás, garázdaság és zaklatás sui generis tényállást képeznek; a rasszizmuson, vallási elöítéleten, szexuális irányultságon, fogyatékosságon, nemi identitáson alapuló ellenérzések súlyosító körülményt képeznek; továbbá arra az esetre, ha olyan védett csoport tagja a sértett, amelyet a jogszabály nem sorol fel, akkor külön rendelkezés tartalmaz iránymutatást a bíróságok számára súlyosító körülményként történő figyelembevételre.

A rasszista motivációt tartalmazó sui generis tényállást a Crime and Disorder Act 1998 (CDA 1998) vezette be, majd az Anti-terrorism, Crime and Security Act 2001 módosította és beiktatta a vallási elöítéletet is mint motívumot. Az 1998-as jogszabály 29-32. szakaszai ${ }^{341}$ határozzák meg azokat a büncselekményeket, amelyek esetében, ha az elkövetőt elöítélet motiválja, vagy elöítéletes érzelmeket mutat, akkor a rasszista vagy vallási alapú elöítélettel elkövetetett önálló büncselekmény követi el. Ezen büncselekmények: testi sértés (29. szakasz), rongálás (30. szakasz), garázda jellegü bűncselekmények (31. szakasz), zaklatási tényállások (32. szakasz). A 28. szakasz a rasszista illetve vallási alapú ellenérzésről mint motivációról: ha az elkövetés időpontjában, közvetlenül azt megelőzően vagy követően az elkövető az áldozat vélt vagy valós faji vagy vallási csoporthoz tartozásán alapuló ellenérzéseket mutat; vagy a cselekményt részben vagy egészben az áldozat adott faji csoporthoz tartozása miatti előítélet motiválja. Faji csoport alatt a jogszabály a faj, bőrszín, állampolgárság, etnikai vagy nemzeti származás szerinti védett tulajdonságokat érti. Vallási csoportot megillető védelem jár a vallási meggyőződés megléte és a vallási meggyőződés hiánya esetén is. Ennek megfelelően zárt listát tartalmaz a jogszabály.

${ }^{340}$ R. v. Baxter, [1997] O.J. No. 5811 (Prov. Div.)

${ }^{341}$ Meaning of racially or religiously aggravated (Section 28), Racially or religiously aggravated assaults (Section 29), Racially or religiously aggravated criminal damage (Section 30), Racially or religiously aggravated public order offences (Section 31), Racially or religiously aggravated harassment etc. (Section 32). Lásd http://www.legislation.gov.uk/ukpga/1998/37/part/II (2014. június 15.) 
Az ellenérzés fogalmát a jogalkotó nem határozta meg, de rendőrségi útmutatókban meghatározzák, hogy az ellenérzés magában foglal minden olyan érzést, mint például rossz szándék, neheztelés, gyülölködés, megvetés, elöítélet, ellenségeskedés, harag és ellenszenv. ${ }^{342}$ Burney és Rose kifejti, hogy az ellenérzés nyilván kevésbé erős, mint a gyülölet, annak egy alacsonyabb szintjét foglalja magában, azonban nyilvánvalóan több mint tiszta elöítélet. ${ }^{343} \mathrm{Az}$ ellenérzés megnyilvánulhat szavakban, gesztusokban vagy más formában, mint például jelképek viseletében (horogkereszt) vagy akár bizonyos dalok éneklésében is. ${ }^{344}$

A 28. szakasz a gyülölet-büncselekmény két formáját tartalmazza: az a) pont esetében az ellenérzés külső megnyilvánulását kell csupán bizonyítani és nem a szubjektív szándékot, azaz egyfajta objektív tesztröl beszélhetünk; míg a b) pont esetében a szubjektív szándék, motiváció meglétét kell bizonyítani. Számos alsóbb szintű bíróság félreértelmezte a két pont közötti különbséget, így például az „SH”-ügyben ${ }^{345}$ a bíróság a motivációra fókuszált az elkövető „fekete majom” kijelentése kapcsán, ahelyett, hogy a 28. szakasz a) pontja alapján az ellenérzés objektív megnyilvánulását vette volna figyelembe. Az ellenérzés időbeli megnyilvánulása kapcsán elmondható, hogy a 28. szakasz a) pontja esetében az elkövető az ellenséges magatartást a cselekménnyel egy időben, azt közvetlenül megelőzően vagy követően tanúsítja. Míg a b) pontban szabályozott szubjektív motiváció bizonyítása kapcsán bizonyítékul szolgálhat mindaz, amit az elkövető korábban mondott, tett, illetve bizonyos csoportban való tagsága is. ${ }^{346}$

A fenti négy gyülölet-büncselekmény esetében a CDA 1998 az alapbüncselekmény tényállásához rendeli hozzá a rasszista vagy vallási ellenérzést és súlyosabb büntetés kiszabását rendeli az alapbüncselekményhez képest. Ez alapján akár minősítő körülményként is tekinthetnénk a jogszabályban meghatározottakra, azonban több körülmény is azt támasztja alá, hogy a jogalkotó szándéka önálló büncselekmények és nem minősített eset létrahozására irányult. Már 1994-ben voltak próbálkozások kimondottan önálló gyülölet-büncselekményi tényállások megalkotására, azonban a

${ }^{342}$ ACPO: Hate Crime Operational Guidance... 2014, 12.

${ }^{343}$ Elizabeth Burney-Gerry Rose: "Racist offences - how is the law working?" Home Office Research Study 244, 2002, 14.

${ }^{344}$ Law Commission: Consultation Paper No. 213, Hate crime: The Case for Extending the Existing $\begin{array}{lllll}\text { Offences. } & \text { C Consultation } & \text { Paper. } & 2013, & 16 .\end{array}$ http://lawcommission.justice.gov.uk/docs/cp213_hate_crime_amended.pdf (2015.június 15.) ${ }^{345} 25$ [2010] EWCA Crim 1931, [2011] 1 Cr App R 14.

${ }^{346}$ Law Commission, 2013, 18. 
javaslatot végül nem fogadták el. A módosító javaslat a testi sértés és emberölés alaptényállásait érintette volna. ${ }^{347}$ Ezt követően az 1997-es javaslat már kedvezőbb fogadtatásra talált. Az eredeti javaslat a testi sértés és zaklatás tényállásait érintette és kezdetben nem tartalmazta a rongálást és garázda jellegü magatartásokat. Heves vita alakult ki a védett csoportok és a szabályozás mikéntje kapcsán,így például módosító javaslatot nyújtottak be, amely az önálló tényállás megalkotása ellen szólt, azonban a javaslatot visszavonták. ${ }^{348} \mathrm{~A}$ gyülölet-büncselekményekkel kapcsolatos szabályozásokat széles körben feldolgozó nemzetközi útmutatóban ${ }^{349}$ is önálló bűncselekményként kezelik a CDA 1998-ban foglalt tényállásokat.

A gyülölet-büncselekmények szabályozásának kérdése 2013-ban a Jogi Bizottság ${ }^{350}$ elé is került az Igazságügyi Minisztérium megkeresése alapján. ${ }^{351}$ A Bizottság feladata az volt, hogy áttekintse a gyülölet-büncselekményekkel kapcsolatos hatályos szabályozást, és választ adjon két kérdésre, nevezetesen: indokolt-e a Crime and Disorder Act 1998ban szabályozott tényállások kiterjesztése az ismert öt védett csoportra; illetve az izgatási tényállások kiterjesztése az öt védett csoportra. A Bizottság megállapította, hogy a minősített esetként szabályozás hatékony eszköz a gyülölet-büncselekményekkel szembeni fellépés terén. A kommunikációs hatása a szabályozásnak abban is rejlik, hogy a bíróság nyílt tárgyaláson is megjelöli, hogy a büntetést azért emelte, mert a gyülöletmotiváció folytán a cselekmény súlyosabban minősül. A Bizottság két ajánlást fogalmazott meg, amelyekkel álláspontja szerint optimalizálható a hatályos szabályozás: új büntetéskiszabási útmutató javasolt a bíróságok számára; illetve minden alkalommal, amikor ezen tényállások alapján szabnak ki büntetést a bünügyi nyilvántartásban jelöljék meg, hogy a bűncselekményt elöítélet motiválta.

Az angol szabályozás négy különféle izgatási tényállást is tartalmaz, amelyeket csak speciális jellegükből kifolyólag említ a dolgozat. A tényállások az alábbiak: rasszista gyülöletre uszítás; vallási gyülöletre uszítás; homofób gyülöletre uszítás; rasszista

\footnotetext{
${ }^{347}$ Law Commission 2013, 5.

${ }^{348}$ Law Commission 2013, 6-9.

${ }^{349}$ Lásd: EBESZ/DIEJH Hate Crime Laws... 2009, 33.

${ }^{350}$ A Jogi Bizottság (Law Commission) egy független öttagú testület, amelynek tagjait a lordkancellár (Lord Chancellor) és az igazságügy-miniszter közösen jelölnek 5 évre. A bizottság rendszeresen készít javaslatokat a kormányzat számára a jog olyan területeiről, amelyek idejétmúltak, túlszabályozottak, vitatottak esetleg nem kellően méltányosak. http://lawcommission.justice.gov.uk/

${ }^{351}$ Lásd Law Commission: Hate Crime. http://lawcommission.justice.gov.uk/areas/hate_crime.htm
} 
„kántálás”. ${ }^{352} \mathrm{Az}$ első három tényállás lényegében azonos tartalmú a védett csoporttól eltekintve. Az elkövetési magatartások a fenyegető szóhasználat vagy ilyen magatartás tanúsítása, illetve bármely írásbeli megnyilvánulás, amelynek célja megfélemlítés az adott csoport elleni gyülölet felszításával. A kántálás rasszista természetűvé azáltal válik, hogy részben vagy egészben megfélemlítő, szitkozódó vagy sértő az adott csoport tagjaira nézve.

A szabályozás harmadik típusa, amikor a bíróság az előítélet-motivációt, ellenérzést a jogszabály rendelkezése alapján súlyosító körülményként veszi figyelembe a büntetés kiszabása során. A Criminal Justice Act 2003 (CJA 2003) magasabb büntetési tétel kiszabását írja elő a 145. szakasz keretében. ${ }^{353}$ Eszerint, ha a 29-32. szakaszok alkalmazására nincs lehetőség, de rasszista vagy vallási előítélet által motivált a cselekmény, akkor a bíróságoknak súlyosító körülményként kell figyelembe vennie és nyilvános tárgyaláson megjelölni az ilyen motivációt. A 146. szakasz ugyanezt írja elö a szexuális irányultságon, fogyatékosságon, nemi identitáson alapuló előítélet esetére. Azaz a jogalkotó az előítélet-motivációt, mint súlyosító körülményt a jogszabályban is megjelöli. Illetve az emberölés esetét kivéve, ${ }^{354}$ amennyiben az ellenséges magatartás nem szerepel külön minősítő körülményként a CJA 2003 156. szakasz (1) bekezdést szem elött tartva kell kiszabni a büntetést (súlyosító körülmény). Emellett a büntetéskiszabásra vonatkozó útmutató ${ }^{355}$ példálózó felsorolást ad az esetleges súlyosító körülményekről. Ennek megfelelően magasabb büntetés kiszabását indokolja, ha: a cselekményt egy kisebbségi csoport vagy annak tagja/tagjai elleni ellenséges érzelmek motiválják; a szándékos cselekmény „sebezhető” áldozat ellen irányul; 356 a büncselekményt hatalmi vagy bizalmi helyzettel visszaélve követik el; illetve az áldozat különösen sérülékeny.

A CDA 1998 29-32. szakaszai Wales esetében is hatályosak. A skót szabályozás hasonló az angol megoldáshoz. Külön tényállás szabályozza a zaklatás minősített esetét

\footnotetext{
352 Racialist chanting, Football (Offences) Act 1991, 3. szakasz. A rasszista kántálás büncselekménye labdarúgó mérkőzésen követhető el.

${ }^{353}$ CJA 2003 145. http://www.legislation.gov.uk/ukpga/2003/44/section/145 (2014. október 29.)

${ }^{354}$ Emberölés büncselekménye esetén az elöítélet motivációt a 21. szakasz rendelkezései alapján értékeli a jogalkalmazó.

355 Sentencing Guidelines Council: Overarching Principles: Seriousness. 2004. http://sentencingcouncil.judiciary.gov.uk/docs/web_seriousness_guideline.pdf

${ }_{356} \mathrm{Az}$ útmutató nem határozza meg a sebezhetőség fogalmát, de példákkal szolgál, így sebezhető az áldozat például koránál, fogyatékosságánál vagy végzett munkájánál fogva.
} 
a Criminal Law (Consolidation) (Scotland) Act 1995 50/A. szakaszában, ${ }^{357}$ amelyet a CDA 1998 33. szakasza ${ }^{358}$ módosított és ugyanúgy tartalmazza a fent említett objektív és szubjektív tesztet. A skót szabályozás azonban csak a rasszista motiváció tekintetében tartalmaz rendelkezéseket. Emellett a CDA 1998 96. szakasza 359 szabályozza a rasszista motivációt és a Criminal Justice (Scotland) Act 200374. szakasza $^{360}$ a vallási alapú elöítéletet mint súlyosító körülményt. Végül az Offences (Aggravation by Prejudice) Scotland Act $2009^{361}$ rendelkezik a fogyatékosságon, szexuális irányultságon és nemi identitáson alapuló előítéletről. Észak-Íroszág szabályozása néhány ponton eltér az angol szabályozástól, így például a Criminal Justice (No.2) (Northern Ireland) Order 2004 ugyan nem hoz létre új tényállást, de iránymutatással látja el a bíróságokat a gyülölet-büncselekményekkel kapcsolatos büntetéskiszabás vonatkozásában, alkalmazni rendeli az ismert objektív és szubjektív tesztet, azonban nem rendelkezik a nemi identitásról, mint védett tulajdonságról. A jogszabály 3. cikke kiterjeszti a Public Order (Northern Ireland) Order 19878. szakaszának rendelkezéseit ${ }^{362}$ a szexuális irányultságra és fogyatékosságra. A 8. cikk határozza meg a vallási nézet, szexuális irányultság, fogyatékosság, bőrszín, faj, nemzetiség (ideértve állampolgárság), etnikai vagy nemzeti származás miatti fenyegetés és gyülöletet fogalmát. ${ }^{363}$

Angliával ellentétben Németországban semmilyen szinten nincs külön gyülöletbüncselekményekkel kapcsolatos szabályozás, sem külön tényállás, sem minősített eset, sem büntetési tételt megemelö rendelkezés formájában és a Btk. súlyosító körülményként sem említi. Büntetéskiszabási szempontból természetesen súlyosító körülményként értékelendő a StGB (Strafgesetzbuch, német Btk.) 46. szakasza alapján, amely a motiváció súlyosító körülményként értékelését írja elő, de nem jelöli meg magát az előítélet-motivációt. 2012-ben volt egy kísérlet a rasszista motiváció 46. szakaszba történő beiktatására, de a törvényjavaslat végül nem kapott kellő támogatást.

\footnotetext{
357 Criminal Law (Consolidation) (Scotland) Act $1995 \quad$ 50/A. http://www.legislation.gov.uk/ukpga/1995/39/section/50A (2014. október 29.)

${ }_{358}$ CDA 1998 33. http://www.legislation.gov.uk/ukpga/1998/37/section/33 (2014. október 29.)

${ }^{359}$ CDA 1998 96. http://www.legislation.gov.uk/ukpga/1998/37/section/96 (2014. október 29.)

${ }^{360}$ Criminal Justice (Scotland) Act 2003 74. http://www.legislation.gov.uk/asp/2003/7/section/74 (2014. október 29.)

361 Public Order (Northern Ireland) Order 1987 8. http://www.legislation.gov.uk/asp/2009/8/contents (2014. október 29.)

362 Amelyek kizárólag izgatási tényállások.

363 ACPO, 2014, 15.
} 
Az indokolás szerint szükségtelen a rasszista motiváció törvénybe iktatása, hiszen a bírák eleve figyelembe veszik azt a büntetés kiszabásakor. ${ }^{364}$

A vizsgált országok által választott szabályozási modelleket az alábbi táblázat foglalja össze:

\begin{tabular}{|c|c|c|c|c|c|}
\hline & $\begin{array}{l}\text { Büntetési } \\
\text { megoldások }\end{array}$ & tételt érintó & szabályozási & $\begin{array}{l}\text { Büntetési tételt } \\
\text { nem érintő } \\
\text { súlyosító } \\
\text { körülményként } \\
\text { való } \\
\text { szabályozás }\end{array}$ & $\begin{array}{l}\text { Külön } \\
\text { szabályo } \\
\text { zást nem } \\
\text { tartalma } \\
\text { zó }\end{array}$ \\
\hline & $\begin{array}{l}\text { sui generis } \\
\text { tényállás }\end{array}$ & $\begin{array}{l}\text { minősítő } \\
\text { körülmény }\end{array}$ & $\begin{array}{l}\text { (általános } \\
\text { részi) } \\
\text { büntetési tételt } \\
\text { megemelö } \\
\text { rendelkezés }\end{array}$ & & \\
\hline Anglia & $\mathbf{X}$ & $\mathbf{X}$ & - & $\mathbf{X}$ & - \\
\hline Dánia & - & - & - & $\mathbf{X}$ & - \\
\hline Kanada & - & $\mathbf{X}$ & - & $\mathbf{X}$ & - \\
\hline Németország & - & - & - & - & $\mathbf{X}$ \\
\hline
\end{tabular}

\section{Jogalkalmazás}

A jogalkalmazás szempontjából elsősorban a rendőrségi szervezeti megoldásokra fókuszál a dolgozat, mivel a jogalkalmazás szintjén a gyülölet-büncselekmények áldozatai elsőként a rendőrséggel kerülnek kapcsolatba és a rendőrség által végzett tevékenység, a bizonyítékok kezdeti feltárása, amely a büntetőeljárást a leginkább befolyásolja, illetve jellemzően a rendőrség szintjén találkozhatunk speciális

364 Comparative Hate Crime Research Report, Oxford Pro Bono Publico, 2014.10. http://ohrh.law.ox.ac.uk/wordpress/wp-content/uploads/2014/05/Oxford-Pro-Bono-Publico-ComparativeHate-Crime-Research-Report-April-2014.pdf 
megoldásokkal a gyülölet-büncselekmények elleni fellépés területén. A jogalkalmazást illetően sehol nem találunk egységes megoldást a gyülölet-büncselekményekkel szembeni rendőrségi fellépésben. Számos megoldás született az elmúlt évek során, de alapvetően négy kategóriába sorolhatók szervezeti megoldás szempontjából, amelyek az ellátott feladatok jellege alapján tovább bonthatók:

\section{A) Gyülölet-büncselekményekért felelős rendőrségi összekötő kinevezése}

A gyülölet-büncselekményekért felelős rendőrségi összekötő intézménye országonként eltérő gyakorisággal fordul elő. Az összekötő rendőr alkalmazása egy kifejezetten költségkímélő megoldás, amely leginkább akkor javasolt, ha az adott körzetben/területen alacsonyabb arányban fordulnak elő gyülöletmotiválta büncselekmények. Összekötőket általában védett csoportok szerint alkalmaznak. Az összekötők lehetséges feladatai általánosságban négy tevékenységcsoportban összegezhetők, amelyek változó összetételben jelennek meg. Az összekötő felelős az adott közösséggel való kapcsolat fenntartásáért, mind általában véve, mind egy adott büntetőeljárás során; koordinációs és facilitátori feladatokat látnak a közösségi kapcsolatok terén; az összekötő általános jelleggel figyelemmel kísér minden esetet, ahol felmerül a gyülöletmotiváltság, az esetleges félreminősítések elkerülése érdekében; végül speciális tudást biztosítanak az osztályszintű válaszok terén. ${ }^{365}$

B) Külön, helyi szintü gyülölet-büncselekmények elleni nyomozati egység létrehozása

Ezt a megoldást főként olyan területeken alkalmazzák, ahol nagyobb számban tapasztalhatók gyülölet-büncselekmények vagy a rendelkezésre álló források lehetővé teszik az ilyen szintü kiemelt figyelmet. Az ilyen egységek jellemzően részletes stratégiával és eljárásrenddel rendelkeznek a gyűlölet-bűncselekményekre vonatkozóan, a nyomozók speciális képzésben részesülnek, és hármas feladatkörrel rendelkezhetnek. Elláthatnak speciális nyomozói feladatokat, képzési feladatokat és felderítői tevékenységet is végezhetnek. A nyomozati feladatok körében különösen a kritikus pontnak számító bizonyítási feladatok terén hárul felelősség az egység tagjaira. Oktatási tevékenységet mind a rendőrségen belül, mind a lakosság körében elláthatnak. Végül az esetleges adatgyüjtési feladatok kiterjednek a gyülöletincidensek nyomon követésére,

365 Canadian Centre for Justice Studies: Hate Crime in Canada: An Overview of Issues and Data Sources. 2001. 20. http://publications.gc.ca/Collection-R/Statcan/85-551-XIE/0009985-551-XIE.pdf (2015. március 2.) 
valamint a helyi szélsőséges csoportok és egyének folyamatos figyelemmel kísérésére, amely leginkább prevenciós célokat szolgál. A külön gyülölet-büncselekményekre specializálódott egység számos előnyt jelent mind a rendőrség, mind az áldozatok számára. Megkönnyíti a sikeres nyomozati eljárásokról szóló tudósítást, ezzel is közvetítve, hogy a rendőrség határozottan lép fel az ilyen cselekményekkel szemben. Emellett segíti a jó gyakorlatok ki- és továbbfejlesztését, valamint hatékonyabbá és gyorsabbá teszi a nyomozást, ha ezen a téren tapasztalattal és szakértelemmel rendelkező nyomozók foglalkoznak az ügyekkel. ${ }^{366}$ Olykor e külön egységek hatáskörébe nem csupán a gyülölet-büncselekmények tartoznak, hanem például extrémizmussal összefüggő egyéb cselekmények vagy családon belüli erőszak.

C) Nagyobb közigazgatási területet (pl. tartományt, megyét) átfogó külön egység létrehozása vagy nyomozó kinevezése

Költségkímélőbb megoldás, mint a helyi szintü egység létrehozása, ha nagyobb közigazgatási területeken hatáskörrel rendelkező egységet hoznak létre vagy e nagyobb területért felelős személyt neveznek ki. Az egységek/nyomozók sokszor általában rendszeres találkozókat szerveznek az információk megosztása és proaktív stratégiák megalkotása érdekében.

Természetesen vannak olyan országok, ahol egyáltalán nem szentelnek kiemelt figyelmet a gyülölet-büncselekményeknek és az általános szervezeti és hatásköri keretek között látják el a nyomozással kapcsolatos feladatokat. Ehhez képest köztes megoldásként találhatunk arra példát, hogy ugyan nincs speciális szervezeti egység a gyülölet-büncselekményekre nézve, azonban igyekeznek a rendőrség valamennyi tagja számára speciális képzést, egységes szervezeti fellépést és írott protokollokat biztosítani a gyülölet-büncselekmény elleni hatékony fellépés érdekében.

A fenti modellek az ellátott feladatok szempontjából további csoportokra bonthatók. Eszerint többféle lehetőség kínálkozik: az adott egység vagy személy csupán felügyeleti feladatokat lát el, speciális szakértelemmel segítve a helyi egységeket és biztosítva az egységes eljárást; vagy akár nyomozati feladatok is telepíthetők a gyülöletbüncselekményekért felelős személy(ek)hez, akár teljesen átruházva a hatáskört ezekben az ügyekben; végül egy olyan megoldás is létezik, amely alapján az

${ }^{366}$ Uo. 74. 
egység/személy alapvetően felügyeleti tevékenységet lát el, de bonyolultabb ügyekben akár nem csupán segíti a nyomozást, hanem teljes egészében átveszi azt. A külön egység létrehozása elismert jó példa, azonban gyakorlati szempontok sokszor azt diktálják, hogy a rendelkezésre álló források és a minőségi szolgáltatás egyensúlyát szem előtt tartva kell kialakítani a rendszert. Kevésbé forrásigényes megoldás például, ha olyan egységet hoznak létre, amelynek ugyan nem tartozik hatáskörébe a nyomozások lefolytatása, de biztosítja helyi szinten a gyülölet-büncselekményekre adott válaszok hatékonyságát. ${ }^{367}$

A fenti modellek mindegyikére találhatunk példákat a vizsgált országokban. Dániában nincs speciális egység, Németországban a - későbbiekben részletezett - speciális adatgyüjtési kategóriához kötődően tartományi és nagyvárosi szinten is vannak külön kijelölt egységek/rendőrök valamint rendőrségi összekötők, míg Kanadában és Angliában több modell is megjelenik.

A dán rendőrségi szervezetrendszerben ugyan nincs olyan speciális egység, amely az előítélet-vezérelte büncselekményekkel kapcsolatos nyomozati feladatokat ellátná, azonban a hírszerző ügynökség fókuszában megtalálhatók a gyűlölet-büncselekmények az extrémizmussal összefüggésben, leginkább az adatgyüjtéssel kapcsolatban. ${ }^{368}$

Németországban szigorú értelemben szintén nem találunk külön gyülöletbüncselekmények elleni osztályokat. Azonban tartományi szinten vannak kijelölt rendőrök, akik kiemelt feladatokat látnak el a politikai indíttatású büncselekmények kapcsán, illetve tartományi szinten (pl. a fỏvárosban, Szászországban, Szász-Anhaltban) specializált osztályokat hoztak létre, amelyek egyéb ügyek mellett a politikai indíttatású cselekményekkel foglalkoznak. A berlini tapasztalatok is azt mutatják, hogy a specializált, adott védett csoporttal kapcsolatot tartó rendörök alkalmazása hatékony megoldás lehet a gyülölet-büncselekmények elleni fellépés terén. Ennek megfelelően összekötő rendöröket is alkalmaznak több helyen (a politikai indíttatású bűncselekményekért felelős osztály mellett), különböző védett csoportok szerint, így

\footnotetext{
${ }^{367}$ ACPO 2005, 57. http://www.bedfordshire.police.uk/pdf/tacticalguidance.pdf

${ }^{368}$ Válaszlevél a Dán Emberi Jogi Intézettől egy a szervezeti megoldásokról érdeklődő levélre, amelyet a GYEM (Gyülölet-büncselekmények Elleni Munkacsoport) küldött ki a szervezetnek 2013 folyamán.
} 
például LMBT összekötő rendőrök dolgoznak Berlinben. ${ }^{369}$ Emellett a speciális nyomozati feladatok ellátása érdekében külön képzésben részesítik a felelős ügyészeket is. ${ }^{370}$ Minden igyekezet ellenére az áldozatvédelmi szervezetek tapasztalata alapján elmondható, hogy továbbra is problémát jelent a gyülölet-büncselekmények „félreminősítése”. Az elmúlt évek fejlesztései ellenére előfordul, hogy a rendörök nem ismerik fel a gyülöletmotivációt - különösen akkor, ha az elkövető egyetlen szélsőséges csoporthoz sem köthető, így képzések szervezése továbbra is ajánlott lenne az állomány jelenlegi és jövőbeli tagjai számára. ${ }^{371}$

Angliában sem mindenhol találhatóak külön gyülölet-büncselekmények elleni nyomozati egységek vagy speciálisan erre a feladatra kiképzett nyomozók, de a nagyobb városokban, városiasabb területeken törekszenek a külön egység létrehozására. Londonban a Metropolitan Police Service (MPS) keretein belül az ún. Community Safety Unit rendelkezik hatáskörrel a gyülölet-büncselekmények (és családon belüli erőszak) esetén. A csoport tagjai speciális képzésben részesülnek, amely a közösségi kapcsolatokra, helyi kulturális kérdésekre is kiterjed. Különös hangsúlyt fektetnek a feljelentési hajlandóság növelésére. Mindig a területileg illetékes kapitányság végzi a nyomozást, azonban az áldozat bármely kapitányságon informálódhat az ügy állásáról. Az MPS honlapján széles körben találhatók információk a bejelentés megtételének különböző módjairól, kihangsúlyozva, hogy bárki bárhol feljelentést tehet, így az áldozatnak nem szükségszerü közvetlenül kapcsolatba lépni a rendőrséggel.

A gyülölet-büncselekmények és incidensek bejelentésére számos lehetőség kínálkozik, így: a központi sürgősségi vonalon; online; nyomtatvány segítségével (amit a rendőrségre kell beküldeni); ún. „third party reporting” formájában („harmadik fél”, azaz közvetítő szervezet segítségével); vagy az ún. crimestoppers elnevezésű csoport segítségével. ${ }^{372}$ A Greater London nevezetü közigazgatási egységben ${ }^{373}$ a True Vision $^{374}$ gyülölet-büncselekmények online bejelentésére szolgáló adatlapja kitöltésével küldhető el a bejelentés. A True Vision elsősorban a jelentési hajlandóság elősegítését

${ }^{369}$ Human Rights Watch: The State Response to "Hate Crimes" in Germany. Human Rights Watch Briefing Paper, 2011, Police Response to Hate Crimes. http://www.hrw.org/news/2011/12/09/stateresponse-hate-crimes-germany (2014. november 5.)

${ }^{370}$ Uo. Judicial Response to Hate Crime.

${ }^{371}$ Human Rights Watch, 2011, Police Treatment of Hate Crime as Ordinary Offenses

${ }^{372}$ Metropolitan Police, Community Safety Unit. http://content.met.police.uk/Site/communitysafetyunit

${ }^{373}$ Londont is magában foglaló közigazgatási egység.

${ }^{374}$ True Vision. http://www.report-it.org.uk/home 
és megkönnyítését hivatott szolgálni. Az adatlap minden alapvető jelentőségü információra rákérdez, amely a későbbi nyomozás során segítségül szolgálhat, így többek között: az elkövetés helyére; motivációra; ki jelenti az incidenst (az áldozat maga, szemtanú vagy más személy); incidens részletes leírása; miért észlelte úgy az áldozat/szemtanú, hogy az elkövetőt gyülöletmotiválta; elkövetőre vonatkozó adatok; illetve az áldozatok személyes komfortját elősegítendő rákérdeznek a kapcsolatfelvétel módjára (megadott saját elérhetőségen vagy harmadik személy útján). Az ún. „third party reporting” kapcsán az MPS oldalán lista található azon szervezetekről - védett csoportok szerint rendezve -, amelyekkel az áldozat/bejelentő felveheti kapcsolatot. Valamennyi védett csoportra kiterjedő tevékenységet lát el a Stop Hate UK ${ }^{375}$ elnevezésű gyülölet-büncselekmények bejelentésével kapcsolatos feladatokat végző országos szervezet, amely a gyülölet-büncselekmények mellett a diszkriminációs ügyekkel is foglalkozik, áldozatokat támogató tevékenységgel, illetve tréningek, képzések, tanácsadás és kampányok lebonyolításával.

Emellett olyan egységre is találunk példát, amelynek ugyan nem tartozik hatáskörébe a nyomozások lefolytatása, de biztosítja helyi szinten a gyülölet-büncselekményekre adott válaszok hatékonyságát. Ez a modell Angliában Merseyside modellként is ismert, ${ }^{376}$ és hatékonynak bizonyult az elmúlt évek során. Egy ún. „Hate Crime Incident Management Unit” biztosítja a nyomozások hatékonyságát és következetességét. Ugyan nyomozati feladatokat nem lát el, de felügyeli és koordinálja a gyülöletbüncselekményekre adott válaszokat, és segítséget nyújt a nyomozóknak.

Az Egyesült Királyságban további példákat is találhatunk. Észak-Írországban 2006 márciusától 2012-ig a 02/06 számú rendőrségi irányelv rendelkezett a gyülöletbüncselekményekre adandó rendészeti válaszokról. Világosan lefektetette azon szabályokat és alapelveket, amelyek mentén az észak-írországi rendőrség (Police Service of Northern Ireland, PSNI) ${ }^{377}$ köteles volt eljárni. Mind központi szinten az ún. közösségi biztonsági részlegen (Community Safety Branch) belül, mind a hely szinten a kerületi egységekben (District Command Uniton) belül ún. kisebbségi összekötők (Minority Liasion Officers) látták el többek között a gyülölet-büncselekményekkel

\footnotetext{
${ }^{375}$ Stop Hate UK. http://www.stophateuk.org/

376 ACPO: Hate Crime: Delivering a Quality Service. Good Practice and Tactical Guidance. $2005,57$. http://www.bedfordshire.police.uk/pdf/tacticalguidance.pdf

${ }^{377}$ Police Service of Northern Ireland (PSNI). http://www.psni.police.uk
} 
kapcsolatos feladatokat, emellett egy kerületi egységben külön gyülöletbüncselekményekre szakosodott egység is müködött. Egyes kerületi egységeken belül müködő közösségi biztonsági egységek (Community Safety Unit) vagy Criminal Justice Union keretein belül különböző számú kisebbségi összekötő látta el a feladatait, volt ahol egy fős, volt ahol több mint hét fős személyi állománnyal dolgoztak. A 20122017-re vonatkozó rendészeti stratégiának ${ }^{378}$ egyik fó irányvonalát a gyülöletbüncselekményekkel kapcsolatos prevenció és nyomozások hatékonyságának növelése képezi. A stratégia gyakorlati megvalósításának részleteiről a „Service Procedure 16/12, Police Response to Hate Incidents" rendelkezik. Ennek megfelelően minden Neighbourhood Policing Uniton ${ }^{379}$ belül, minden kerültben ún. „Hate and Signal Crime Officerként” tiszthelyettesi rangban látják el a nyomozati feladatokat. A PSNI jelenleg hat gyülölet-büncselekmény típust különböztet meg: felekezeti hovatartozáson alapuló, rasszista, homofób, valláson, fogyatékosságon, nemi identitáson alapulót. ${ }^{380}$

Skóciában egy ún. Specialist Crime Division (SCD) látja el a gyülöletbüncselekményekkel kapcsolatos nyomozati feladatokat a „Safer Communities” elnevezésű területen belül (hat másik terület, például szervezett bünözés, hírszerzési feladatok mellett). Az SCD 2013. április 1-je óta látja el tevékenységét több mint kétezres személyállománnyal, nemzeti szintű koordinációval, helyi szintű működéssel. 381

Kanadában sincs egységes megoldás a gyülölet-büncselekményekkel szembeni rendőrségi fellépés terén. Számos megoldás született az elmúlt évek során, de alapvetően mindegyik fent említett modell megtalálható valamilyen formában.

A leggyakoribb megközelítés, hogy nincs külön egység vagy személy, de igyekeznek képzéseket biztosítani az állomány valamennyi tagja számára Ezt a megoldást alkalmazza például a haltoni regionális rendőrség, a saskatooni rendőrség, a waterloo-i regionális rendőrség és a yorki regionális rendőrség. Ezen rendőrségek körülbelül

\footnotetext{
378 PSNI: Equality, Diversity and Good Relations Strategy 2012-2017. http://www.psni.police.uk/equality_diversity__good_relations_strategy.pdf

${ }^{379}$ Adott körzetben kisebb területeken látnak el feladatokat az egység tagjai, így például középiskolákban tanulókkal és tanárokkal egyaránt.

${ }^{380}$ Gary Reid: The Role of the Police in Adressing Hate Crime: The Case of the Police Service of Northern Ireland. 2013. http://www.enargywebzine.eu/spip.php?article306

381 Lásd Scottish Police Authority: Specialist Crime Division launches. 2013. http://www.spa.police.uk/news/2013/march/183240/ és Police Scotland: Specialist Crime Division. http://www.scotland.police.uk/about-us/police-scotland/specialistcrime-division/
} 
egyharmada gyüjt statisztikai adatokat gyülölet-büncselekményekre vonatkozóan. ${ }^{382}$

A gyülölet-büncselekményekért felelős rendőrségi összekötő intézménye a legritkább szervezeti megoldások körébe tartozik. Gyülölet-büncselekményekért felelős összekötőt alkalmaz például a calgary-i rendőrség és a niagarai regionális rendőrség. ${ }^{383}$

Külön nyomozati egységet föként olyan területeken hoznak létre, ahol nagyobb számban tapasztalhatók gyülölet-büncselekmények. Ezt a megoldást alkalmazza Edmonton, Ontario tartomány, Toronto és Winnipeg. ${ }^{384}$

Végül a közös egység alapú megközelítést alkalmazza például British Columbia gyülölet-büncselekmény csoportja, amely lényegében valamennyi a tartományban működő rendörséget összefogja. Brit Columbia az egyetlen tartomány, amely központilag egységes stratégiát alkalmaz. A tartományi gyűlölet-büncselekmények elleni csoportot 1996-ban hozták létre az egységes fellépés biztosítása érdekében. Az iroda 1997-ben kezdte meg müködését és tevékenysége nem csupán a gyülöletbüncselekmények, hanem a gyülöletbeszéd területére is kiterjed. Az évek során számos útmutatót és protokollt készített a csoport. Emellett különös figyelmet fordítanak az adatgyüjtésre is, adatbázist vezetve a tartományi szinten jelentett gyülöletbüncselekményekről. Az adatbázisban szerepel az elkövetés ideje, helye, a büncselekmény típusa, az elkövető és áldozat közötti kapcsolat, demográfiai információk mind az áldozatra, mind az elkövetöre vonatkozóan. Néhány információt csak belső célokra használnak, a többi adatot rendszeresen publikálják. ${ }^{385}$ Az egységes eljárásrendnek megfelelően a különböző osztályok mindenhol együttmüködnek a hatékony fellépés érdekében a büntetőeljárás teljes időtartama alatt, beleértve az információgyüjtést, elemzést, a felderítő tevékenység eredményeként szerzett információk megosztását, stratégiák fejlesztését.

Kanadában folytatott kutatásaim során alkalmam nyílt az edmontoni gyülölet-

\footnotetext{
${ }^{382}$ Canadian Centre for Justice Studies: Hate Crime in Canada: An Overview of Issues and Data Sources. 2001 , http://www.albertahatecrimes.ca/09/images/file/Documents/Resources/Hate\%20Crime\%20in\%20Canada $\% 20$ Overview\%20(STATS\%20Canada\%202001).pdf (2014. augusztus 7.)

383 Uo. 21.

384 Uo. 21.

385 Uo. 38.
} 
büncselekmények elleni osztály müködését közelebbről is megvizsgálni. ${ }^{386} \mathrm{Ez}$ a megoldás leginkább a ,külön nyomozati egység”-modellbe sorolható és vegyes rendszernek tekinthető az ellátott feladatok szempontjából.

Az edmontoni gyülölet-büncselekmények elleni egység 2003 óta müködik, kezdetben három, majd egy átszervezést követően két taggal a szervezett bűnözés elleni osztály keretein belül. Az egység tagjai folyamatosan figyelemmel kísérik a különböző helyi szélsőséges csoportok és személyek tevékenységét, segítséget nyújtanak, illetve maguk is végeznek nyomozati cselekményeket, különböző oktatási feladatokat látnak el, valamint a jó gyakorlatok kialakításában és terjesztésében is aktívan részt vesznek. Az egység tagjai alapvetően a belső informatikai rendszeren belül értesülnek a potenciális gyülölet-büncselekményekről. A járőrök, illetve a rendőrség más tagjai a rendszerben megjelölik, ha elöítélet-motiváció gyanúja merül fel, így a gyülölet-büncselekmények elleni egység azonnal értesül az esetről. Innentől kezdve kétféle alternatíva kínálkozik a nyomozati munkát illetően. Az esetek többségében csupán felügyeleti tevékenységet látnak el, de a nyomozást alapvetően az a körzet végzi, ahol a büncselekményt elkövették. Ilyen esetben a büntetőeljárást végig figyelemmel kísérik, szakmailag felügyelik, és segítséget nyújtanak a bizonyítékok gyüjtésében és. Ha az ügy mélyebb nyomozást igényel, akkor teljesen átveszik a nyomozást. Az edmontoni rendőrség tájékoztatása szerint az így beérkezett ügyek kb. 50\%-ában indul nyomozás gyülöletbüncselekmény miatt, 25\%-a az ügyeknek csupán gyülöletincidens, amely nem mindősül büncselekménynek, illetve további 25\%, amelyről kiderül, hogy csupán valamelyik alapcselekmény gyülöletmotiváció nélkül. Az egység átlagban évente 130 ügyben érintett.

A nyomozati feladatok mellett idejük nagy részét a felderítési, adatgyüjtési és oktatási feladatokra fordítják. A felderítési, adatgyüjtési komponens folyamatos gyülöletpropaganda, internetes gyülölet-büncselekmények (főként inkább izgatási cselekmények) és szélsőséges csoportok/személyek monitorozását öleli fel. Oktatási tevékenységük egyaránt kiterjed az állományon belüli képzésekre és az oktatási intézményekben végzett tudatosságnövelő előadásokra. A rendőrségi újoncképzés 21 hetes időszakot ölel fel, amely elméleti és gyakorlati képzési időszakra bomlik. Az

\footnotetext{
${ }^{386}$ Forrás: Dan Woodall-lal, a gyülölet-büncselekmények elleni egység tagjával 2014 augusztusában jelen tanulmány céljából - folytatott interjúkból származnak az alább található, edmontoni gyülöletbüncselekmények elleni egységre vonatkozó információk.
} 
elméleti képzés keretében minden újonnan kiképzett jelölt négyórás gyülöletbüncselekményekről szóló tréningen vesz részt, amelyet a gyülölet-büncselekmény elleni egység tagjai tartanak. A képzés keretében többek között megismertetik a jelölteket a leggyakoribb gyülöletszimbólumokkal, a legismertebb gyülöletkeltő website-okkal, részletes útmutatást kapnak a motiváció bizonyítására nézve (gyülöletbüncselekmények elkövetését alátámasztó tényezők, példákkal szemléltetve), esetelemzésekkel kapnak nagyobb rálátást a gyakorlatra. 2007-ben az egység segítséget nyújtott a „Canadian Police Knowledge Network”-nek a most már országosan alkalmazott, gyülölet és elöítélet által vezérelt büncselekményekre vonatkozó nyomozati kurzus kialakításában. ${ }^{387} \mathrm{Az}$ egység más országos rendőrségi szervezeti egységekkel közösen kialakított egy információs rendszert, amelyen keresztül az egész országban lehetővé válik a szélsőséges csoportokról szerzett információk cseréje. A rendszer elindítása jelenleg is folyamatban van, annak technikai hátterének pontosítása folyik. Üzembe helyezését követően lehetővé válik például, hogy az ország bármely pontjáról hozzáférjenek a gyülölet-büncselekmény egységek más egységek ügyeihez, szélsőséges csoportokról és személyekről gyüjtött információkhoz, információt és segítséget kérjenek egymástól, megosszák a jó gyakorlataikat stb.

Az egység belső jelentési adatlapot használ, amelyen megjelölik például a büncselekményt, az elkövető ismert-e, mikor történt az eset, illetve a motivációra vonatkozóan is szolgáltatnak adatot (faj/etnikai hovatartozás, vallás, szexuális irányultság, nyelv, fogyatékosság, nem, kor, egyéb körülmény jelölhető meg motivációs tényezőként). ${ }^{388}$ Az edmontoni megoldásról elmondható, hogy vegyes rendszer, amely alapvetően a fenti harmadik kategóriába tartozó megoldást alkalmazza, azaz külön nyomozati egységet tart fenn, azonban megtalálhatók benne egyéb elemek is, föként a nyomozati tevékenységeket illetően. Mint külön egység maguk is végezhetik a nyomozást vagy csupán szakmailag felügyelik azt, és segítséget nyújtanak az olyan kritikus pontokon, mint a bizonyítékok gyüjtése. Ez a rendszer egyaránt hatékony a rendőrség és az áldozatok szempontjából, tehermentesíti a - gyülölet-büncselekmények terén tapasztalattal nem rendelkező - nyomozókat, biztosítja a szakmailag egységes fellépést.

387 The City of Calgary: Overview of Standards for Hate/Bias Crime Reporting and Investigation, 2008, 9.

http://www.albertahatecrimes.ca/09/images/file/Documents/Resources/Overview\%20of\%20Standards\%2 0for\%20Hate\%20Bias\%20Crime\%20Reporting\%20and\%20Investigation.pdf (2014. augusztus 7.)

${ }^{388}$ Edmonton Police Service, Uniform Crime Reporting (UCR) Survey, Incident Based. 
A leggyakrabban alkalmazott jogalkalmazási modellek az alábbi táblázat szerint összegezhetőek a fent kifejtettek alapján:

\begin{tabular}{|c|c|c|c|c|}
\hline & $\begin{array}{l}\text { Rendőrségi } \\
\text { összekötő }\end{array}$ & $\begin{array}{l}\text { Helyi szintü, } \\
\text { külön nyomozati } \\
\text { egység/nyomozó }\end{array}$ & $\begin{array}{l}\text { Nagyobb } \\
\text { közigazgatási } \\
\text { területet átfogó } \\
\text { külön } \\
\text { egység/nyomoz } \\
\text { ó }\end{array}$ & $\begin{array}{l}\text { Nincs külön } \\
\text { személy/egység }\end{array}$ \\
\hline Anglia & $\mathbf{X}$ & $\mathbf{X}$ & $\mathbf{X}$ & $\mathbf{X}$ \\
\hline Dánia & - & - & - & $\mathbf{X}$ \\
\hline Kanada & $\mathbf{X}$ & $\mathbf{X}$ & $\mathbf{X}$ & $\mathbf{X}$ \\
\hline Németország & $\mathbf{X}$ & - & $\mathbf{X}$ & $\mathbf{X}$ \\
\hline
\end{tabular}

\section{Adatgyưjités}

Adatgyüjtés tekintetében modellek felállítására nem igazán van lehetőség. Csupán felmérhetjük, hogy melyek azok a megoldások, ezek egyes elemei, amelyek megfontolandók a magyar adatgyüjtési rendszer fejlesztése során. Ami bizonyos, hogy egyre kevesebb olyan ország van, ahol semmilyen szinten nem gyüjtenek adatokat. Ez javarészt a nemzetközi nyomásnak is köszönhető, hiszen egyre több ajánlás, iránymutatás fogalmazódik meg az adatgyüjtési rendszerek kiépítésére vonatkozóan, ${ }^{389}$ illetve több nemzetközi szervezet is rendszeresen kér adatokat a tagállamoktól a gyülölet-büncselekmények számát illetően. ${ }^{390}$ Az adatgyüjtéssel kapcsolatos problémák nem is az ezzel kapcsolatos tevékenység teljes hiányára vezethetők vissza, hanem az adatgyüjtési rendszer egyes pontjaira. A dolgozat elsősorban a hivatalos adatgyüjtési rendszereket vizsgálja és legfeljebb érinti a nem hivatalos, többnyire a hivatalos adatgyüjtési hiányokat kompenzáló, általában civil szervezetek által végzett monitoring

${ }^{389}$ Lásd pl. Report of the UN High Commissioner for Human Rights, A/HRC/19/41 (nineteenth session, 2011) Discriminatory laws and practices and acts of violence against individuals based on their sexual orientation and gender identity; Miniszteri Bizottság CM/REC(2010)5. sz. ajánlása a tagállamok felé $a$ szexuális irányultság, illetve nemi identitás alapján történő diszkrimináció leküzdését célzó intézkedésekröl vagy ECRI 11. sz. általános ajánlása: A rasszizmus és a faji megkülönböztetés ellen a rendfenntartás területén folytatott küzdelemröl.

${ }^{390}$ Lásd például: OSCE Ministerial Council Decision No. 9/09 Combating hate crimes vagy FRA: Making hate crime visible in the European Union: acknowledging victims' rights, 2012. 
tevékenységet. Bár már utóbbi tevékenységekre is komplex képzéseket és útmutatókat találhatunk. ${ }^{391}$ Emellett a vizsgált országok alapján az áldozati kutatásoknak is jelentős szerepe lehet. Valamennyi országban készülnek áldozati kutatások, amelyek egészen eltérő eredményeket mutatnak a hivatalos bünügyi statisztikákhoz képest. Azonban épp e különbségek motiválják a hatóságokat a rendszer hatékonyságának növelésére, az anomáliák kiküszöbölésére és arra, hogy a jelenségről teljesebb képet kapva igyekezzenek a prevencióra is hangsúlyt fektetni.

Az adatgyüjtéssel kapcsolatos feladatokat Dániában 2009 óta a hatékonyság növelése érdekében elsősorban a biztonsági és információs szolgálat ${ }^{392}$ látja el. A PET már 1992től kezdődően kapott adatokat a rendőrségtől olyan ügyekről, ahol felmerült a rasszista büncselekmény gyanúja. 2001-ben módosították az adatgyüjtési rendszert, amely innentől kezdve minden olyan esetről rögzített adatokat, ahol rasszista vagy vallási ellenséges érzület mint motívum gyanúja felmerült. Azonban az adatgyüjtés hatékonyságát célzó mindennemü intézkedés ellenére számottevő bizonytalanságot tapasztaltak, és a minták feltárására alkalmatlannak bizonyult a rendszer. Erre tekintettel 2009-ben a rendszert felülvizsgálták és átalakították. A PET a rendőrségi adatbázisból maga nyeri ki az adatokat, amely sokkal átfogóbb és hitelesebb képet ad a gyülöletmotiválta büncselekmények jelenségéröl. Emellett kiterjesztették az adatgyüjtést a rasszista és vallási gyülöleten kívüli egyéb gyülölet-bűncselekményekre is, így a faj, bőrszín, állampolgárság, etnikai hovatartozás, vallási nézet és szexuális irányultság mint védett tulajdonságok alapján gyüjtik az adatokat. 2010 novemberében publikálták az új rendszer alapján elkészült első jelentést, amelyben a lehetséges gyülölet-büncselekmények száma jelentősen magasabb volt, mint az előző években, ${ }^{393}$ amely vélhetően az adatgyüjtési rendszerben eszközölt változásoknak tulajdonítható elsősorban. A gyülölet-büncselekményekkel a PET az extrémizmus fogalmi keretein belül foglalkozik. A PET szoros együttmüködésben áll a dán rendőrséggel annak biztosítása érdekében, hogy a hatáskörrel rendelkező egységek kellő figyelmet szenteljenek a szélsőséges megnyilvánulásoknak. Tehát nyomozati feladatokat továbbra

\footnotetext{
${ }^{391}$ Lásd például CEJI 2012.

392 Danish Security and Intelligence Service, Politiets Efterretningstjenestes, PET https://www.pet.dk/English.aspx (2014. Június 9.)

393 EBESZ adatok alapján 2008-ban 0, 2009-ben 2 esetet rögzítettek. Ezzel szemben 2010-ben mintegy 334 gyülölet vezérelte büncselekményt rögzítettek. Lásd EBESZ Hate Crime Monitoring és EBESZ/DIEJH Hate Crimes in the OSCE Region 2009. 23. http://www.osce.org/files/documents/9/6/73636.pdf (2014. szeptember 7.)
} 
sem lát el a PET, csupán a megelőzés, figyelemfelkeltés és adatgyüjtés terén lát el feladatokat. $^{394}$

Mindazonáltal az igazságügyért felelős minisztérium által végzett, áldozatokra vonatkozó kutatások ${ }^{395}$ alapján még mindig jelentős eltérés mutatkozik a megkérdezettek áldozattá válására vonatkozó adatok és a PET által nyilvántartott adatok között. A kutatás a fent említett problémára, az alacsony jelentési hajlandóság okira is kitér. A felmérés ugyanazon eredményekre vezetett, mint a legtöbb eddig publikált áldozati kutatás. Eszerint elsősorban bizalmatlanok a megkérdezettek az eljárás kimenetelét illetően, illetve attól félnek, hogy a feljelentés hátrányos személyes következményekkel járna és inkább nem jelentik az esetet. Emellett szintén okként merült fel, hogy az áldozatok sokszor nincsenek tisztában jogaikkal vagy azzal, hogy a támadás egyáltalán eléri-e a büncselekményi szintet. A civil szervezetekkel és áldozatokkal késztett interjúk arra is rávilágítottak, hogy sokszor nem gyülöletbüncselekmény miatt indítanak nyomozást, így ezek az esetek meg sem jelennek a hivatalos statisztikákban. Az ítéletekre vonatkozóan jelenleg pedig semmilyen adat nem áll rendelkezésre. 2007-ben az ügyészség ideiglenesen adatokat gyüjtött azokról az esetekről, ahol a büntetést a 81. szakasz 6. pontja alapján szabták ki és így mindösszesen 10 esetet rögzítettek, de az adatgyüjtés ilyen formáját azóta sem rendszeresítették. 396

Angliában gyülölet-büncselekményekre vonatkozó adatokat különböző módon és célból, különféle kormányzati és igazságügyi szervek gyüjtenek. Jelenleg a jelentett és regisztrált ügyek számára, az indult büntetőeljárások számára vonatkozóan állnak rendelkezésre adatok öt védett csoportra ${ }^{397}$ lebontva. Ezen kívül arra is találhatunk adatokat, hogy a jelentett ügyek esetében mennyiben indítottak eljárást, hoztak ítéletet, hány esetben szabtak ki büntetést a gyülölet-büncselekmény rendelkezések alapján, és mekkora a kiszabott szabadságvesztés büntetések átlagos időtartama. Mivel az adatgyüjtés alapját a CDA 19998 29-32. szakaszokban szabályozott önálló

\footnotetext{
$394 \quad$ Lásd $\quad$ PET: Crimes by https://www.pet.dk/English/Counter\%20extremism/Crimes\%20motivated\%20by\%20extremism.aspx (2014. június 9.)

${ }^{395}$ Lásd például Research Unit of Ministry of Justice, Denmark.

396 Lásd PET.

397 2007-ben a rendőrség, ügyészség, büntetés-végrehajtás és más igazságügyi szervek megegyeztek a gyülölet-büncselekmények közös fogalmában és a védett csoportokban (faj, fogyatékosság, nemi identitás, szexuális irányultság és vallás), amelyek alapján az adatgyüjtést is végzik.
} 
büncselekmények képezik, amelyek csupán a rasszista és vallási motivációjú elöítéletbüncselekményekre vonatkoznak, ezért ezen utóbbi statisztikákban nem szerepelnek a másik három védett csoport elleni cselekmények miatt indult eljárásokra vonatkozó adatok. A hivatalos statisztikáknak két fö forrása van: az ún. „Crime Surves for England and Wales" $(\mathrm{CSEW})^{398}$ és a rendőrségi statisztikai nyilvántartás.

A CSEW 1982 óta folytatott, bünözéssel kapcsolatos felmérés, amely Angliára és Walesre terjed ki, és amelynek során arról kérdezik a lakosság tagjait, hogy az elmúlt egy évben büncselekmény áldozataivá váltak-e; az egyes büncselekménytípusok elterjedtségének és természetének vizsgálata érdekében. A 2012-2013-as év során 50.000 háztartás vett részt a felmérésben, amely a fel nem jelentett esetekre is kiterjed. A felmérés keretében az angliai és walesi háztartások 16 év feletti tagjait kérdezik arról, hogy a felmérést megelőző tizenkét hónapon belül büncselekmény áldozataivá váltak-e ő maguk vagy a velük egy háztartásban élők, és ha igen, akkor hány alkalommal. A felmérés során, sajnos, csak a rasszista motivációra kérdeznek rá a gyülöletvezérelte büncselekmények körében, egyéb (például antiszemita vagy homofób) motivációra nem. A felmérés módszertanát illetően megjegyzendő, hogy ha tizenkét hónapon belül több mint hat különböző incidens történt a válaszadóval, akkor csak az első hat jelent meg az eredmények között; illetve, ha egy bizonyos büncselekmény többször fordult elö, akkor sorozatos cselekményként tüntetik fel.

A rendőrségi és ügyészségi adatgyüjtés többféleképpen történik; 2013-ban azonban a Belügyminisztérium, Központi Statisztikai Hivatal és az Igazságügyi Minisztérium első ízben - átfogó közös jelentést publikált, amely a különböző forrásokból származó statisztikai adatokat összegzi. ${ }^{399}$

A jelentés öt fejezetre oszlik. Az első fejezet tartalmazza a CSEW alapján becsült viktimizációs adatokat és a rendőrség által rögzített bejelentett ügyek számát. A bejelentést felvevő rendőr a belső rendszerben megjelölheti egy-egy bejelentés kapcsán az esetleges elöítélet-motivációt az öt védett csoport alapján. Ezen jelölésekből áll össze később a bejelentett gyülölet-büncselekményekre vonatkozó statisztika. A 2012/13-as

\footnotetext{
${ }^{398}$ Lásd CSEW. http://www.crimesurvey.co.uk

${ }^{399}$ Home Office, Office for National Statistics and Ministry of Justice: An Overview of Hate Crime in England and Wales, 2013. december, http://report-it.org.uk/files/ons_hate-crime-report_2013.pdf
} 
évben 42.236 gyülölet-büncselekményt ${ }^{400}$ rögzítettek ilyen formában Angliában és Walesben. A 2011/12-es és 2012/13-as CSEW adatokra tekintettel a gyülöletbüncselekmények becsült száma 278.000. ${ }^{401}$ Mint látható a két adat között jelentős különbség van, amelynek azonban számos oka van. Egyrészt a CSEW adatok majd három éves időszakot ölelnek fel, míg a rendőrségi adatok egy költségvetési évre vonatkoznak. Másrészt a CSEW egy áldozatokra vonatkozó kutatás, amely becsléseken is alapszik, és megjelenhetnek benne olyan esetek is, amelyeket nem jelentenek be. A CSEW rákérdez ugyan, hogy az eset a rendőrség látókörébe került-e, de ez nem feltétlenül jelenti, hogy az ügyet jelentették is. Előfordulhat ugyanis, hogy a rendőrség például szemtanúja egy cselekménynek, de adott esetben úgy értékeli, hogy az nem éri el a bűncselekményi határt, és ezért nem indít eljárást. ${ }^{402}$

A második fejezet egy összefoglalót tartalmaz az öt védett csoport szerint a fenti két adatbázis alapján. A harmadik fejezet azon regisztrált eseteket tartalmazza, amely CDA 1998 29-31. szakaszai alapján minősülnek, és amelyekről a rendőrség vezet nyilvántartást. A negyedik fejezet a bírósági ítélkezési felmérés alapján gyüjtött adatokra vonatkozó kiegészítő adatokat tartalmazza. Végül az ötödik fejezet a CSEW adatokat elemzi a rendőrség munkájával való elégedettségről, érzelmi hatásokról.

A jelentés az alábbi nyilvántartások és adatok alapján készült:

- CSEW

- Rendőrségi nyilvántartás: amikor egy lehetséges gyülölet-büncselekmény a rendőrség látókörébe kerül központilag meghatározott ${ }^{403}$ szempontok szerint rögzítik. A rögzített adatokat megküldik a belügyminisztériumnak 43 területi egység szerint (plusz brit közlekedési rendőrség). A belügyminisztérium továbbítja ezen adatokat a központi statisztikai hivatalnak, ${ }^{404}$ amely a gyülölet-büncselekményekre vonatkozó statisztikai adatok nyilvánosságra hozataláért felelős 2012 áprilisa óta. ${ }^{405}$

\footnotetext{
400 Uo. 18.

${ }^{401}$ Uo. 21.

402 További okokra lásd uo. 21-22.

${ }^{403}$ Lásd Home Office Counting Rules (https://www.gov.uk/government/publications/counting-rules-forrecorded-crime) és National Crime Recording Standard (https://www.gov.uk/government/publications/the-national-crime-recording-standard-ncrs-what-youneed-to-know) alapján meghatározott szempontok alapján.

${ }^{404}$ Office for National Statistics. http://www.ons.gov.uk/ons/index.html

${ }^{405}$ Home Office, 2013. 49-50.
} 
- Rasszista vagy vallási előítélet, mint minősített eset: A regisztrált büncselekményeket csupán e két szempont alapján tartják nyilván, tekintettel arra, hogy a jogszabály csak ezen minősített eseteket tartalmazza a CDA 1998 29-31. szakaszokban. Az ezekre vonatkozó bünügyi statisztikai adatokat a belügyminisztérium évente hozza nyilvánosságra. Emellett a minisztérium a regisztrált büncselekményekkel kapcsolatos büntetőeljárásokról is gyüjt adatokat (így például a szóbeli vagy írásbeli figyelmeztetéssel zárult eljárásokról, azon eljárásokról, amelyekben vádemelés történt stb.).

- Az igazságügyi minisztérium bírósági eljárásokra vonatkozó nyilvántartása: A minisztérium a bírósági nyilvántartásokból kinyert adatok alapján is gyüjt információkat a gyülölet-büncselekményekkel kapcsolatos folyamatban lévő és lezárt eljárásokról. A rendszer hátránya éppen annak komplexitásában rejlik, így előfordulhat, hogy bizonyos ügyek nem jelennek meg a statisztikában. Ha az elítélt felelősségét két vagy több büncselekmény miatt állapítják meg, akkor a rendszerben az a büncselekmény jelenik meg, amelyért a legsúlyosabb büntetést szabták ki. Ha ugyanolyan mértékü büntetéseket szabtak ki, akkor az a büncselekmény jelenik meg, amelynek a legmagasabb a maximálisan kiszabható büntetési tétele. Illetve csupán az a büncselekmény jelenik meg lezárt, amelyért a büntetést kiszabták, így előfordulhat, hogy az eljárás gyülöletbüncselekmény miatt indult, de a büntetés kiszabásánál az már nem jelenik meg (mert például az angol jogrendszer sajátosságaiból fakadóan beismerő vallomás esetén kisebb büntetést szab ki a bíróság). ${ }^{406}$

- Koronabíróság ${ }^{407}$ ítélkezési felmérése: 2010-ben az ítélkezési tanács ${ }^{408}$ bevezetett egy új bírósági ítélkezési felmérést, ${ }^{409}$ amely alapján a koronabíróságokon meghozott valamennyi ítélet alapján a bíráknak kötelezően ki kell tölteniük egy kérdőívet, információt szolgáltatva a sérülésről, a felelősségről és a súlyosító és enyhítő körülményekről, amelyeket a döntés meghozatala során figyelembe vettek. A többek között testi sértésekre, zaklatásokra vonatkozó adatlapon két helyen jelölendő meg az elöítélet-motiváció: egyrészt a kötelező súlyosító körülmények között megjelölendő,

\footnotetext{
406 Uo. 51.

407 A Korona Bíróságok egyes súlyosabban minősülő ügyekben járnak el (mint például emberölés, szexuális erőszak, rablás), illetve másodfokú bíróságként járnak el a városi bíróság hatáskörébe tartozó ügyekben.

${ }^{408}$ Sentencing Council. Az Ítélkezési Tanács iránymutatást nyújt a bíráknak arról, hogy a különféle bűncselekmények elkövetőivel szemben milyen büntetést szabjanak ki. Lásd http://sentencingcouncil.judiciary.gov.uk

$\begin{array}{llllll}409 & \text { Crown } & \text { Court } & \text { Sentencing } & \text { Survey. } & \text { Bövebben }\end{array}$ http://sentencingcouncil.judiciary.gov.uk/facts/sentencing-survey.htm
} 
hogy rasszista/vallási (e két faktort összevonva tartják számon), fogyatékosságon, szexuális irányultságon, nemi identitáson alapult-e a motiváció vagy ezeken alapuló ellenséges magatartást tanúsított-e az elkövető; másrészt az egyéb súlyosító körülmények között szerepel a kor és nem mint az ellenséges motiváció vagy magatartás alapja. A gyújtogatás és a magyar jog szerint rongálásként meghatározható tényálláshoz hasonló büncselekmények esetében a rasszista és vallási alapú ellenséges magatartás, illetve motiváció összevonva jelenik meg mint súlyosító körülmény. Az „egyéb bűncselekményekre” vonatkozó kérdőívben a súlyosító körülmény úgy jelenik meg, mint egy csoport vagy egyén ellen irányuló ellenséges motiváció. Emellett az Ítélkezési Tanács 2011. június 13-án útmutatót bocsátott ki a testi sértésekre vonatkozóan, amelyben súlyosító körülményként emelte ki az ellenséges magatartás tanúsítását, illetve az ilyesfajta motivációt az öt védett csoport tekintetében. Tehát az adatgyüjtés ebben az esetben sem egységes, hiszen nem minden büncselekményre nézve, és még csak nem is egységes szempontok alapján gyüjtenek adatokat. Bizonyos büncselekmények esetében mind az öt védett csoportra nézve találhatunk adatokat (azonban itt is az rasszista és vallási motiváció egy kategóriát képez), más büncselekményeknél pedig csak két védett csoportra nézve (azt is összevonva), illetve olyan is van, ahol az elöítélet-motiváció védett csoportok nélkül jelenik meg vagy egyáltalán rá sem kérdeznek.

Összességében elmondható, hogy egy igen komplex adatgyüjtési és elemzési rendszert alkalmaz napjainkban az Egyesült Királyság (kiváltképp Angliára és Walesre vonatkozóan), azonban még mindig találhatóak hiányosságok, amelyek szemmel láthatók és jelentősek, ha ezen adatokat összevetjük az áldozatokra vonatkozó kutatások (CSEW) adataival. Ezen hiányosságok főként abból fakadnak, hogy a jogszabályokkal szinkronizált adatgyüjtési rendszer csupán azon fogalmakkal és kategóriákkal dolgozik többnyire, amelyek a hatályos jogszabályokban szakasz szám szerint azonosíthatók, így az egységes gyülöletbüncselekmény-fogalom és egyezményes öt kategória ellenére sok esetben nem áldozati csoportok szerint regisztrálják az indítékot. Problémát jelent az is, hogy a nyomozási és a bírósági szakaszra vonatkozó adatgyüjtési rendszerek nincsenek összekapcsolva, így az egyes ügyeket nem lehet végigkövetni. Nem lehet megmondani például, hogy hány gyülölet-büncselekmény tárgyában indult nyomozás zárult az elkövető gyülölet-büncselekmény miatti felelősségre vonásával. Mindazonáltal pozitívumként emelendő ki, hogy a nemzetközi sztendernek megfelelő statisztikai 
adatgyüjtési célra használható gyülölet-büncselekmény meghatározást vezettek be, ami első lépés az átfogó adatgyüjtési rendszer felé. A rendszernek nagy előnye, hogy lehetővé teszi az elöítéletes indítékra vonatkozó gyanú statisztikai rendszerben történő regisztrálását, illetve adatokat nyújt a kiszabott szankciókra vonatkozóan is. Szintén pozitívum, hogy rendszeres időközönként vesznek fel nagymintás áldozatkutatást, amely a gyülölet-büncselekmények előfordulására, jelentésére vonatkozóan is tartalmaz kérdéseket, és közelebb visz a valós adatokhoz.

Habár Németországban nincs kategória a Btk.-ban a rendőrség mégis gyüjt adatokat a rasszista támadásokról és egyéb gyülöletmotiválta büncselekményekröl. 2001-ben alkották meg a politikai indíttatású büncselekmények fogalmát adatgyüjtési célokból. 2000-ig a német Szövetségi Bünügyi Nyomozóügynökség (Bundeskriminalamt) és a Szövetségi Alkotmányvédelmi hivatal (Bundesamt für Verfassungsschutz) gyüjtött adatokat minden szélsőséges cselekményröl, illetve az idegengyülölettel és antiszemitizmussal kapcsolatos cselekményekröl. Ez elsősorban az olyan állam elleni szélsőséges cselekményekre korlátozódott, amelyek az alapvető demokratikus elvek ellen irányultak. 2000 szeptemberében két cikk jelent meg arról, hogy 10 év alatt mintegy 93 halálos áldozata volt a jobboldali szélsőséges mozgalmak egyre erősödő térnyerésének. Ezzel szemben a hivatalos statisztikák mindösszesen 24 esetet tartalmaztak. A kérdés reflektorfénybe kerülése is szerepet játszott abban, hogy a kormányzat újraértékelte a gyülölet-büncselekményekkel kapcsolatos adatgyüjtési rendszert. A gyülölet-büncselekmény mint fogalom 2001 januárjában jelent meg először az ország büntetőjogi politikájában, amikor a szövetségi belügyminisztérium bevezette az új adatgyüjtési rendszert. Azóta a gyűlölet-büncselekményekkel ezen politikai indíttatású cselekmények körében foglalkoznak. ${ }^{410}$

Az új nyomozati adatgyüjtési rendszerben (Polizeiliches Definitionssystem Politisch motivierte Kriminalität - PMK) a gyülölet-büncselekmények egy alkategóriát képeznek a politikai indíttatású cselekményeken belül. A védett csoportok tekintetében a két

410 Glet, 2009, 4-5. és Mario Peucker: The hate crime concept in Germany and how to improve the knowledge on the extent of hate crimes, Paper prepared for the OSCE meeting "Tolerance Implementation Meeting: Addressing the hate crime data deficit" (Vienna, 8-10 November 2006), Bamberg 2006, 1-2. http://www.efms.uni-bamberg.de/pdf/Hate_crime_concept_final.pdf 
alkategóriát alkalmaznak: idegengyülölö (nemzetiségi, etnikai vagy faji hovatartozáson, bőrszínen, vallási nézeten vagy származáson alapuló) és antiszemita támadások. ${ }^{411}$

A gyakorlatban a rendszer úgy müködik, hogy a helyi rendőr, aki találkozik az esettel eldönti, hogy a politikai indíttatás és gyülöletmotiváció gyanúja felmerül-e. Ezt követően az ügyet központi szinten ismét átnézik és megerősítik a besorolást. Ha nyomozás lezárult, akkor központi szinten jelölik meg az esetet, és továbbítják az adatokat a szövetségi bünügyi nyomozóügynökségnek, ahol összegzik az adatokat. A politikai indíttatást akkor regisztrálják, ha egyértelmü bizonyíték áll rendelkezésre vagy a körülmények alapján feltételezhető a motiváció. A szövetségi nyomozóügynökség által összeállított jelentés azonban nem tartalmazza védett csoportok szerinti bontásban az adatokat, csupán a két alkategóriára (idegengyülölő, antiszemita) lebontva. ${ }^{412}$

Az elmúlt 10-15 évben Németország határozott lépéseket tett az adatgyüjtési rendszer és a gyülölet-büncselekményekkel szembeni fellépés hatékonyságának növelése érdekében. Kétségtelen, hogy az új rendszer minőségi változásokat eredményezett, és lehetővé tette, hogy közelebb kerüljenek a probléma valós súlyának megértéséhez. Azonban vannak bizonyos gyengeségei az új rendszernek is. A politikai indíttatás négy alkategóriát foglal magában: jobboldali és baloldali szélsőséges cselekmény, külföldiek által elkövetett és egyéb politikai indíttatású cselekmények. Ez a megoldás egyértelmüen a szélsőséges mozgalmak ellen szól, de pontosan emiatt vannak esetek különösen, ahol nincs egyértelmü ideológiai motiváció, mint sokszor LMBT személyek és fogyatékossággal élő emberek elleni támadásnál - amelyek rejtve maradnak adatgyüjtési szempontból. Egy áldozatsegítő csoport (Opferperspektive) ${ }^{413}$ a kutatási eredményei alapján megállapította, hogy akkor regisztrálják gyülöletbüncselekményként az esetet, ha az elkövető közvetlenül köthető valamilyen szélsőséges csoporthoz. Emellett többnyire a jobboldali szélsőségesek által elkövetett gyülöletmotiválta büncselekményeket rögzítik. Úgy tünik, hogy a rendszer fő hibája, hogy először a politikai/ideológiai hátteret kell regisztrálni ahhoz, hogy gyülöletbüncselekményként is rögzíthessék. Ugyan az új rendszer nem annyira korlátozódik a

411 Glet, 2009, 5 .

412 Glet 2009, 7.

${ }^{413}$ Nigdy Więcej-Opferpersepektive (szerk.): Hate Crime Monitoring and Victim Assistance in Poland and Germany. 2009, $47 . \quad$ http://www.stiftungevz.de/fileadmin/user_upload/EVZ_Uploads/Publikationen/Englisch/poland_full_english.pdf (2014. november 6.) 
szélsőséges támadásokra, mint a korábbi, de még mindig igényli az elkövető csoporthoz tartozását ahhoz, hogy megfelelően minősítsék és továbbítsák az esetet. ${ }^{414}$ Különösen érzékeny pontja és egyben gyengéje a rendszernek, hogy a minősítés és az adatbázisban való megjelölése a rendőrön múlik, akihez az ügy elsőként kerül. Azonban a hatályos útmutató nem írja elő kötelezettségként a rendőrök számára az ügy nyomon követését. Így például, ha az eljárás későbbi szakaszában az ügyész ismeri fel a motivációt az eset nem fog megjelenni a statisztikában. ${ }^{415}$

Ezen gyengeségek miatt elengedhetetlenek a különböző képzési programok, amelyek a rendőrségi állomány tagjait segítenék a motiváció helyes megítélésében. Az intézmények (rendőrségek, ügyészségek, bíróságok) közötti információcsere lehetővé tételével szintén hatékonyabb lehetne a jelenlegi rendszer. Emellett a határozotton elkövető-központú rendszert közelíteni lehetne egy áldozatközpontú rendszer irányába, ezzel kiküszöbölve a jelenlegi problémákat, amelyek az elkövetőt szükségszerüen szélsőséges csoporthoz kötő megközelítésből adódik. ${ }^{416}$

Kanadában a rendőrség a központi rendszerben az ún. Uniform Crime Reporting Survey (UCR) használatával gyüjt adatokat a gyülölet-büncselekményekre vonatkozóan. A jelentés a büncselekmény számára, jellemzőire, a sértettekre és elkövetőkre nézve tartalmaz információkat. A 2012-es adatok alapján mintegy 1.414 gyülölet által motivált büncselekményt rögzített a rendőrség, amely 4,1 büncselekményt jelent 100.000 före vetítve. Ez azonban csak elenyésző részét képezi a rendőrség által rögzített valamennyi büncselekménynek. Így például a testi sértéseken belül az ügyek 0,09\%-a gyülölet által motivált, míg a rongálások vonatkozásában ez $0,24 \% .{ }^{417}$ A regisztrált büncselekmények több mint fele rasszista motivációjú (704 eset, 51\%), a gyülölet vezérelte büncselekmények 30\%-a (419 eset) vallási előítélet által motivált, 13\% (185 eset) szexuális irányultságon alapuló gyülölet által motivált, végül a maradék $6 \%$ egyéb elöítélet által motivált (nyelv, fogyatékosság, nem, kor és egyéb védett tulajdonságok, mint például politikai nézet). Az 1.414 eset 75\%-ában a rendörség megerősítette a

\footnotetext{
${ }^{414}$ Glet 2009, 13.

${ }^{415}$ Peucker 2006, 4.

${ }^{416}$ Lásd Peucker 2006, 5-6.

417 Ezen adatokban nem szerepel Toronto, Calgary, Québec és Saint John, mert ezen városokban nem állnak rendelkezésre adatok a gyülölet-büncselekményekre vonatkozóan. Illetve a százalékos arányok csupán becsléseken alapszanak, mert a különböző büncselekmények esetében más véghatáridővel dolgoznak. Lásd Government of Canada, Statistics Canada: Police-reported hate crime in Canada, 2012. http://www.statcan.gc.ca/pub/85-002-x/2014001/article/14028-eng.htm\#r1 (2014. augusztus 7.)
} 
gyülöletmotiváltságot, 25\%-ában pedig továbbra is gyülöletmotiváció gyanúja állt fenn. ${ }^{418}$ A központi statisztikai adatok összevetve az áldozatokra vonatkozó kutatásokkal Kanadában is jelentőst eltérést mutatnak. A 2009-es áldozatokra vonatkozó kutatás ${ }^{419}$ eredményei alapján az esetek 5\%-ában (közel 399.000 esetben) a válaszadók úgy érzékelték, hogy a sérelmükre elkövetett cselekményt elöítélet motiválta. ${ }^{420}$

A Btk. ugyan súlyosító körülményként szabályozza a gyülöletmotivációt, azonban jelenleg nem állnak rendelkezésre átfogó statisztikai információk e szabályok alkalmazására vonatkozóan. Mindazonáltal megvizsgálható a bírósági eljárások száma a bírósági statisztikai rendszer ${ }^{421}$ segítségével. Ezen adatok azt mutatják, hogy viszonylag kevés gyülölet-büncselekmény jut el a bírósági szakig. 2009-2010-ben a felnőttkorúak eljárásaiban csak 14 esetben szerepelt a gyülölet-motiváció, ebböl is 10 esetben izgatási ügyben. Míg a fiatalkorúak ügyeiben 5 esetnél jelent meg a gyülöletmotiváció, ebből négy esetben vallási tisztelet tárgyának rongálását állapította meg a bíróság. De ezek a számok még mindig azt jelzik, hogy az esetek többsége nem jelenik meg a bírósági statisztikákban. A kutatások azt mutatják, hogy az esetek igen csekély részében szerepel a vádemelésben a gyülöletmotiváció. ${ }^{422}$ Nagyon kevés ügyésznek van tapasztalata a gyülölet-büncselekményekkel kapcsolatos rendelkezések alkalmazásában, azonban ezen a gyakorlaton is igyekszenek változtatni. Calgaryban és Edmontonban például az ügyészségi adatbázisban - akár csak a rendőrségi rendszerben - lehetőség van a gyűlöletmotiváció megjelölésére. Az ügy ezt követően kerülhetne a gyülöletbűncselekmények terén tapasztalattal bíró ügyészhez. Sajnos, a gyakorlatban ez a rendszer nem bizonyult hatékonynak, főleg az infrastrukturális nehézségek okán. A gyülölet-bűncselekmények aktái már eleve túlterhelt ügyészekhez kerülnek, akik nem képesek az eredetileg tervezett figyelmet szentelni az ügyeknek.

Az ügyészségi és bírósági statisztikák alapján megállapítható, hogy Kanadának még sokat kell tennie e területen, hogy felzárkózzon a folyamatos fejlődő rendőri munkához.

\footnotetext{
${ }^{418}$ Lásd uo.

${ }^{419}$ General Social Survey on Victimization (GSS), 2009. Áldozatokra vonatkozó kutatást minden ötödik évben végeznek. http://www.statcan.gc.ca/pub/85-002-x/2010002/article/11340-eng.htm (2014. augusztus 8.)

420 Bővebben lásd Mia Dauvergne-Shannon Brennan: Police-reported hate crime in Canada, 2009, Juristat. Self-reported victimization data on hate-motivated incidents. http://www.statcan.gc.ca/pub/85002-x/2011001/article/11469-eng.htm (2014. augusztus 8.)

${ }^{421}$ Integrated Criminal Court Survey

422 The City of Calgary, 2008, 11.
} 
Mint minden más büncselekménynél az előítélet motiválta cselekményeknél is elmondható, hogy rendőrség, aki elsősorban felelős a nyomozásért, a minősítésért, és ez határozza meg, hogy miként kerül egy ügy az igazságszolgáltatási rendszer többi szintjének figyelmébe. A gyülölet-büncselekmények esetében első lépés, hogy a rendörség felismerje a gyülöletmotivációt, és ennek fényében folytassa a nyomozást. Amíg sok államban az jelent problémát, hogy a rendőrök nem képesek alkalmazni a rendelkezésre álló jogszabályi keretet, és ezáltal kiüresednek a gyülöletbüncselekményekkel kapcsolatos jogszabályok, addig Kanadában a probléma súlypontja egy szinttel feljebb kerül, és az egyre hatékonyabb rendőri munka üresedik ki azáltal, hogy az ügyészségi és bírósági szinten ,eltünik” a gyülöletmotiváció. ${ }^{423}$

\section{Jó gyakorlatok}

Amint az eddig vizsgált szempontok során is kiderült jó gyakorlatokat valamennyi fenti országban találhatunk. Ezek főként az alábbi területeket érintik: társadalmi figyelemfelhívó és tudatosságnövelő kezdeményezések, oktatási programok; bejelentési hajlandóságot növelő programok; hatósági és civil szervezeti együttműködést kialakító és fejlesztő programok; az adatgyüjtést területét érintő kezdeményezések, legyen szó kutatásokról vagy a hivatalos adatgyüjtési rendszer fejlesztéséről; különféle szervezeti megoldások, tudatosságnövelő, érzékenyítő és nyomozati eljárást érintő képzések a rendőrségen belül; valamint büntetőeljárást érintő kezdeményezések. Ezek persze a legtöbb esetben összefonódnak, de a dolgozat a fenti fő célkitüzések alapján veszi sorra a legjelentősebb kezdeményezéseket.

a) Társadalmi figyelemfelhívó és tudatosságnövelő kezdeményezések, oktatási programok

Dániában a fellépés hatékonyságát növelő kezdeményezések, például különböző kampányok, rendőrségi képzések és a bejelentések egyszerüsítését és ösztönzését célzó programok többségét a Dán Emberi Jogi Intézet ${ }^{424}$ kezdeményezte az elmúlt néhány

${ }^{423}$ Lásd például Jeannine Bell: Policing Hatred. Law Enforcement, Civil Rights, and Hate Crime. New York University Press, 2002, 12-27. és Nathan Hall: „Law Enforcement and Hate Crime: theoritical perspectives on the complexities of policing 'hatred"' in Neil Chakraborti (szerk.): Hate Crime. Concepts, policy, future directions. Willan Publishing, 2010, 149-168.

${ }^{424}$ The Danish Institute for Human Rights, DIHR. http://www.humanrights.dk (2014. június 11.) 
évben. 2010-ben indította el „Stop Hate Crimes”425 elnevezésű tudatosságnövelő kampányát a DIHR és a koppenhágai rendőrség, Koppenhága és Frederiksberg városának együttmüködésében. A projekt a gyülölet-büncselekmények számának csökkentésére, figyelem felhívásra, a feljelentések ösztönzésére és megelőzésre irányult, a hatóságok és civil szervezetek szoros együttmüködésében. A mintegy 146.000 eurós projekt keretében különböző média-kezdeményezésekkel álltak elő, elsősorban a dán büntető törvénykönyvben védett kisebbségi csoportokkal szembeni gyülöletbüncselekmények elleni fellépés érdekében. A gyülölet-büncselekmények leggyakoribb elkövetési helyszíneire fókuszálva számos transzparenst, mintegy száz óriásplakátot helyeztek el a projektben részt vevő két város legforgalmasabb pontjain, buszjáratain, állomásain, és különös hangsúlyt fektettek a célok közösségi médiában való terjesztésére. A kampány részeként egy művészpáros által tervezett üvegdobozban megafont állítottak ki Koppenhága legforgalmasabb vásárlóutcájában, amelyet egy héten keresztül minden nap délben egy férfi használt, azt kiabálva, hogy „Sosem késő bocsánatot kérni!”, ezzel jelezve a külföldiekkel és az állampolgárok egymással szemben tanúsított intoleráns és gyülölködő bánásmód tarthatatlanságát. A kampány keretében terjesztett három plakát a védett csoportok tagjaival szemben elkövetett gyülölet-büncselekményekre fókuszálva, három - egy meleg, egy fekete és egy muzulmán - bántalmazott férfit ábrázol. Mindhárom poszter egy-egy mondatot tartalmaz: „A kékszemű melegek érdekelnek?”; Úgy gondolod, hogy a feketéknek kék szeműnek kellene lenniük?”; „Szerinted a muzulmánok megérdemlik a kék szemet?” (a „kék szem” 'bla ojne' a dán nyelvben a monoklit - angolul 'black eye' - jelenti).

Németországban 2007-ben indult - egy korábbi program folytatásaként - a Diversity Does Us Good - Youth for Diversity, Tolerance and Democracy elnevezésü állami finanszírozású kezdeményezés. A program helyi önkormányzatoknak biztosít lehetőséget, hogy helyi civil szervezetekkel együttmüködve akciótervek keretében lépjenek fel a jobboldali szélsőségekkel szemben, különböző oktatási, tudatosságnövelő kampányok szervezésével. ${ }^{426}$

Szintén a téma iránti állami elköteleződést igazolják azon kerekasztalbeszélgetéssorozatok, amelyeket helyi önkormányzatok szerveztek a jobboldali szélsőségek

425 Stop Hate Crimes kampányra lásd http://www.equineteurope.org/Stop-Hate-Crimes-campaignDenmark (2014. június 10.)

${ }^{426}$ Więcej-Opferpersektive 2009, 35. 
témakörében politikai szereplők, rendőrök, közigazgatásban dolgozók, oktatási szakemberek, civil és vállalati szféra képviselőinek részvételével. ${ }^{427}$

Emellett a Violence Prevention Network évek óta folytatja Taking Responsibility Breaking Away from Hate and Violence elnevezésü, fiataloknak szóló programját. Nem ritka jelenség, hogy fiatalkorúak követnek el gyülölet-büncselekményeket Németországban. Évente 2500 fiatalkorút ítélnek el súlyosabb büncselekményért, amelyek egy jelentős része rasszista vagy idegengyülölet által motivált erőszakos büncselekmény. A büntetés-végrehajtási intézményekben müködtetett prevenciós és nevelési célú program keretében például eröszakellenességröl szóló képzéseken, önismereti foglalkozásokon, tudatosságnövelő órákon, csoportfoglalkozásokon vesznek részt a fiatalok. ${ }^{428}$

A lakossági és rendőrségi tudatosságnövelő kampányok terén számos jó példát találhatunk Kanadában. Lakossági programra példa a Racism Free Edmonton ${ }^{429}$ elnevezésű kezdeményezés, amely 16 edmontoni civil szervezet együttmüködésében jött létre. Cselekvési tervükben olyan célok szerepelnek, mint például: segítik a helyi önkormányzati szerveket esélyegyenlőségi tervek elfogadásában és végrehajtásában, rasszizmus elleni figyelemfelhívó kampányokat szerveznek, és kidolgoznak egy adatgyüjtési rendszert, amely a helyi rasszista incidensek nyomon követésére alkalmas.

b) Bejelentési hajlandóságot növelő programok

A hivatalos statisztikák és az áldozati csoportok körében végzett kutatások azt mutatják, hogy a gyülölet-büncselekményeknek csak a töredéke kerül hivatalosan bejelentésre a bünüldöző szervek felé. A látencia két alapvető következménnyel jár: egyrészt a büncselekmények elkövetői büntetlenül maradnak, másrészt a hatóságok jelentősen alulbecsülik a gyülölet-büncselekmények számát, a probléma súlyát. A gyülöletbüncselekményekkel kapcsolatos alacsony jelentési hajlandóság okait számos kutatás feltárta már és ezen országok mindegyike arról tett tanúbizonyságot, hogy felismerte e

427 Harald Weilnböck: Hate Crime and Radicalisation: the German Political Experience and the $\begin{array}{llll}\text { Schellenberg } & \text { Report. } & 2012, & 47 .\end{array}$ http://www.niacro.co.uk/filestore/documents/hate_crime_project_papers/08_Hate_Crime_and_Radicalisa tion_-_the_German_political_experience_and_the_Schellenberg_Report.pdf (2014. november 3.)

428 Violence Prevention Network, Taking Responsibility - Breaking Away from Hate and Violence http://www.violence-prevention-network.de

${ }^{429}$ Racism Free Edmonton. http://racismfreeedmonton.ca/site/who_we_are 
probléma jelentőségét. Természetesen a társadalmi tudatosságnövelő és figyelemfelhívó kampányok is szolgálják a bejelentési hajlandóság növelését, azonban vannak specifikus kezdeményezések, amelyek kifejezetten a védett csoporti közösségeknek szólnak.

A rendőrségbe vetett általános bizalom növelésére, és a gyülölet-büncselekmények bejelentésének fontosságára történő célzott figyelemfelhívásra segíthet ezen problémák feloldásában, mint például a már említett angol online bejelentési rendszer a True Vision, amelyet a rendörség, kormányzat és egyéb partnerintézmények közösen fejlesztettek ki és hoztak létre. A bejelentések megtételének lehetősége mellett az oldal különféle információval látja el az áldozatokat, illetve az áldozatoknak vagy szervezeteknek lehetőséget kínál arra, hogy az incidenst közvetlenül a hatáskörrel rendelkező rendőrségnél tegyék meg. Egy szintén a gyülölet-büncselekmények bejelentéséhez kapcsolódó jó gyakorlat a GALOP nevü a londoni LMBTszervezethez ${ }^{430}$ köthető. Azok, akik nem szeretnék közvetlenül a rendőrségnél jelenteni a büncselekményt megtehetik a GALOP weblapján vagy telefonos szolgálatán keresztül, ahol egyben segítséget is kaphatnak. Az online nyomtatvány kérdéseket tartalmaz az elkövetés idejére, helyére, a sérülés típusára, a vagyoni kárra, valamint az áldozatra és elkövetőre vonatkozóan. A bejelentő választhat, hogy a GALOP egy segítője vagy a rendőrség vegye fel vele a kapcsolatot, akár anonim is maradhat, és az adatait a szervezet nem továbbítja a rendőrség felé, illetve azt is választhatja, hogy csupán bejelenti az incidenst, de sem a szervezet, sem a rendőrség nem keresi a továbbiakban. ${ }^{431}$

c) Hatósági és civil szervezeti együttműködést kialakító és fejlesztő programok

Már a fenti kezdeményezések is például szolgálnak az együttmüködés fontosságának elismerésére és fejlesztésére, de vannak olyan programok, amelyek kifejezetten az együttmüködés kialakítására fektetik a hangsúlyt.

Németországban jó példa a rendőrség és bevándorlói közösségek együttmüködésére a Mannheim városában müködő program. A rendőrség kijelölt tagjai állandó kapcsolatban vannak a török kisebbség képviselőivel, és folyamatosan részt vesznek

${ }^{430}$ GALOP. http://www.galop.org.uk/

${ }^{431}$ CEJI 2012, 29. 
közösségi rendezvényeken is. A modell sikeresnek bizonyult, ugyanis a rendőrségbe vetett bizalom erősítésével hozzájárult például a jelentési hajlandóság növeléséhez is. ${ }^{432}$

Szintén említést érdemel az kanadai Alberta tartomány gyülölet-büncselekmények elleni bizottsága. ${ }^{433}$ A bizottság jogelődjét (Alberta Hate Bias Crime and Incidents Committee) 2001-ben hozták létre igazságszolgáltatási, kormányzati és közösségi szervezetek közösen és szoros együttmüködésben áll a tartomány érdekelt civil szervezeteivel. Célja, hogy tartományi szinten átfogó gyülölet-bűncselekmény stratégiát dolgozzon ki, és kereteket adjon az együttes és hatékony gyülölet-büncselekmények elleni fellépésnek, mind az igazságszolgáltatási szervek, mind a közösségek számára.

\section{d) Adatgyüjtést területét érintő kezdeményezések}

Az angol megoldások közül elsősorban a Community Security Trust (CST $)^{434}$ elnevezésű szervezet emelendő ki, amely 1984 óta rögzít antiszemita incidenseket, és készít éves jelentéseket ezekről az incidensekről, valamint nyújt különféle segítséget (például tréningek, tanácsadás) antiszemita incidensek sértettjeinek. Emellett számos útmutatót készített a szervezet, mint egy harmincéves fennállása óta, így például: 2007ben jelent meg „Police Officer's Guide to Judaism” című, rendőrök számára készült útmutató a zsidó vallás legfontosabb szokásait ismerteti; a 2010-ben publikált „A Guide to Fighting Hate Crime" című útmutató ${ }^{435}$ hasznos iránymutatást ad a bejelentésekre, rendőrséggel való együttmüködésre és az áldozattámogatásra vonatkozóan. Éves jelentései ${ }^{436}$ az antiszemita incidensekről nem csupán a rögzített incidenseket tartalmazzák, hanem az ügyek részletes leírását és elemzését is.

Németország esetében mindenképp jó példaként említhető - minden hibája ellenére - az új, átfogó, államilag egységes adatgyüjtési rendszer bevezetése. Az új fogalom

\footnotetext{
${ }^{432}$ Fundamental Rights Conference, Comating Hate Crime in the EU. Giving Victims a face and a voice. Vilnius, Litvánia, 2013. novemeber 12-13., Working Group - reporting back, 1. http://fra.europa.eu/sites/default/files/frc_2013_day_2_wg_iii_working_group_harvest_capacity_building _and_training.pdf (2014. november 3.)

${ }_{433}$ Alberta Hate Crime Committee. http://www.albertahatecrimes.ca/

${ }^{434}$ Community Security Trust. http://www.thecst.org.uk/

435 Lásd Community Security Trust: A Guide to Fighting Hate Crime. http://www.thecst.org.uk/docs/Hate\%20Crime\%20booklet\%20-\%20Web\%20version.pdf (2014. október 29.)

436 Lásd például a 2011-es jelentést. CST: Antisemitic Incidents Report 2011. http://www.thecst.org.uk/docs/Incidents\%20Report\%202011.pdf (2014. október 29.)
} 
bevezetése kétségtelenül maga után vont szervezeti változásokat, új képzéseket (így például érzékenyítő és szakmai képzéseket).

Kanadában a minden ötödik évben végzett általános áldozatokra vonatkozó kutatás (GSS) tartalmaz kérdéseket a gyülöletmotivációra vonatkozóan is, és az így kapott adatokat közösen publikálják a rendőrségi statisztikákkal, így lehetővé téve az egyszerübb összehasonlítást. ${ }^{437}$ A kutatás során 15 év feletti kanadaiakat kérdeznek arról, hogy a felmérést megelőző tizenkét hónapon belül meghatározott büncselekmények (pl. rablás, lopás, testi sértés, garázdaság stb.) áldozataivá váltak-e, és ha igen, akkor tapasztaltak-e gyülöletmotivációt az elkövető részéröl.

e) Különféle szervezeti megoldások, tudatosságnövelö, érzékenyítő és nyomozati eljárást érintő képzések a rendőrségen belül

Dániában 2010-2011 folyamán a DIHR hét másik európai uniós tagállam ${ }^{438}$ civil szervezeteivel együttmüködésben a „Tracing and Tackling Hate Crime against LGBT Persons" elnevezésű uniós projekt keretében az LMBT személyek elleni gyülöletbüncselekményekre fókuszálva rendőrségi képzések tartása mellett kifejlesztett egy képzési anyagot, amely egy nyomozati protokollt is magában foglal ${ }^{439}$ és mind a nyolc ország nyelvén hozzáférhető. ${ }^{440}$ Mindemellett az intézet átfogó kutatást végzett és publikált a gyülölet-büncselekményekkel szembeni állami fellépés hatékonyságáról, vizsgálva a rendőrségi, ügyészségi és bírósági gyakorlatot, bemutatva a nemzeti szabályozást és Dániára háruló nemzetközi jogi kötelezettséget, valamint javaslatokat megfogalmazva a jogalkalmazás számára.

A rendőrségen belüli elöítéletek visszaszorításában fontos szerepe lehet például az ún. összekötő rendőröknek, akik a rendörség és a közösség közötti kapocsként müködnek. Az LMBT közösségekkel kapcsolatban a közösség és a rendőrség közötti bizalom javítása, valamint ezáltal a gyülölet-büncselekményekkel kapcsolatos jelentési hajlandóság növelése érdekében LMBT összekötő pozíciókat hoztak létre az Egyesült

${ }^{437}$ EBESZ/DIEJH: Hate Crime Data-Collection ... 2014. 40.

${ }^{438}$ Franciaország, Írország, Lettország, Németország, Portugália, Románia, Svédország.

${ }^{439}$ Nyomozati anyagra lásd ILGA: Project by carried out by the DIHR: Tracing and Tackling Hate Crime against LGBT Persons. http://www.ilga-europe.org/home/issues/hate_crime_hate_speech/projects/dihr (2014. Június 11.)

440 DIHR: Action against Hate Crimes. http://humanrightsvia.inforce.dk/focus+areas/equal+treatment/the+horizontal+approach/projects/action+a gainst+hatecrimes (2014. június 11.) 
Királyságban. ${ }^{441}$ Általános jelleggel fontos megjegyezni az összekötő pozíció kapcsán, hogy kizárólag akkor müködőképes, ha folyamatos képzik és támogatják az összekötőket. A problémára nem megoldás, ha csupán ad hoc jelleggel kijelölnek egy munkatársat, aki a meglévő feladatok ellátást mellett egy ilyen pozíciót is betölt mindennemü képzettség, illetve a közösséggel kapcsolatos tudás és kapcsolat nélkül.

Képzések területéről is bőven szolgál jó példával az Egyesült Királyság, így például az MPS az Arsenal Football Clubbal együttmüködésben dolgozott ki képzési programot a rendezők számára, amely a rendőrséggel való együttmüködést, illetve a szurkolók körében tapasztalható elöítéletes cselekmények visszaszorítását célozza. A rendőrségen belüli képzések is egyre gyakoribbak, így például Bradford városában 2013 októberében több mint 400 rendőrt képeztek a gyülölet-büncselekmények témakörében. ${ }^{442}$

A különböző védett csoportok tagjai jogainak tiszteletben tartása nem csupán a rendőrségen, hanem a kormányzaton belül is kellö súlyt kap az Egyesült Királyságban. $\mathrm{Az}$ College of Policing ${ }^{443}$ által 2014-ben elfogadott stratégia ${ }^{444}$ a gyülöletbüncselekményekkel kapcsolatos állami fellépés valamennyi területére, így különösen a megelőzésre, a bejelentési hajlandóság növelésére, a hatékony nyomozásokra, az áldozatok segítésére és a különbözö képzésekre is kiterjed. Emellet külön városi stratégiákat is találhatunk, így Bradford városa a 2013-2016-os időszakra saját gyülöletbüncselekmény-elleni stratégiát készített, amely a helyi körülményeket is szem elött tartja. ${ }^{445}$

A gyülölet-büncselekményekkel kapcsolatos rendőrségi szervezeti megoldások terén jó példáként szolgál a már szintén említett Merseyside modell, amely a gyakorlati tapasztalatok alapján sikeresnek bizonyult. A modell egyik fontos eleme az áldozatoknak átnyújtandó „,csomag” (Victim Pack), amely tartalmazza: a segélyvonal telefonszámát; tájékoztató anyagot a merseyside-i rendőrségről,

\footnotetext{
441 ACPO 2005, 87.

${ }^{442}$ Lásd Bradford People First: Hate Crime Training. http://www.bradfordpeoplefirst.org.uk/hate-crimetraining/

443 A Belügyminisztérium által 2011-ben létrehozott rendőrségi szakmai szervezet. Lásd http://www.college.police.uk/

444 College of Policing: National Policing Hate Crime Strategy, 2014. http://www.reportit.org.uk/files/national_policing_hate_crime_strategy.pdf

445 Bővebben lásd Bradford and District: Hate Crime Strategy 2013-2016. http://www.bhca.info/documents/Bradford\%20Hate\%20Crime\%20Strategy\%202013-16\%20-

$\%$ 20final.pdf
} 
fogalommeghatározásokkal együtt; az áldozatsegítéssel foglalkozó valamennyi intézmény elérhetőségét; valamennyi gyülöletbüncselekmény-koordinátor nevét és elérhetőségét; bejelentőlapot; valamint különböző nyelveken biztonsági tanácsokat. Ezzel párhuzamosan egy gyülölet-büncselekmény csomagot is kialakítottak a rendőrség munkatársai számára. ${ }^{446}$

Kanadában a rendőrségi szervezetrendszerben szintén nincs hiány jó példákra. A legtöbb nagyvárosi rendőrség igyekszik valamilyen formában kiemelt figyelmet szentelni a gyülölet-büncselekményeknek. Azonban még mindig nincs egy egységes képzési rendszer, amely tovább növelhetné a gyülölet-büncselekmények elleni fellépés hatékonyságát. Szintén jó példaként említhetők a különböző, a rendőrségen belüli sokszínűséget elősegítő kezdeményezések. Így például számos nagyvárosban volt olyan toborzási program, amely más országok rendőreinek adott lehetőséget arra, hogy a hosszú és körülményes kanadai bevándorlási eljárást elkerülve jelentkezzenek az állományba. ${ }^{447}$ Hasonló programot hirdettek Calgary városában is, ahol mintegy 100 új, az Egyesült Királyságból érkező taggal bővült az állomány. A British Columbiában 1996 óta három taggal (két rendőr és egy ügyész) müködő B.C. Hate Crime Team szintén kiemelkedő szervezeti megoldásnak számít. A csoport az egész tartományban végzi a gyülölet-büncselekményekkel szembeni, egységes fellépést biztosító tevékenységét. ${ }^{448}$

\section{Összegzés}

A gyülölet-büncselekményekkel szembeni fellépés terén egészen eltérő megoldásokat alkalmaznak az egyes államok, legyen szó a szabályozásról, jogalkalmazásról vagy adatgyüjtésről. Mára számos országban teremtették meg a gyülölet-büncselekményekre vonatkozó szabályozás alapjait, azonban még mindig heves viták zajlanak a szabályozás megfelelő módjairól. A különböző jogalkotási modellek mindegyikére, illetve vegyes

\footnotetext{
446 ACPO, 2005. 61.

${ }^{447}$ Lásd például Sarah Chapman: Canada Recruits British Police Officers, Toronto News and Views. http://torontonews.wordpress.com/2007/12/31/uk-policemen-enticed-to-canada/ (2014. október 29.) és Edmonton Police Service: an exciting policing career awaits you in Edmonton, Alberta. Canada. http://www.joineps.ca/ApplicationProcess/ /media/Join\%20EPS/Files/An\%20exciting\%20policing\%20c areer\%20awaits\%20you.ashx (2014. október 29.) Ezzel a programmal került az edmontoni rendőrséghez például Cst. Daniel Woodall, a gyülölet-büncselekmények elleni egység tagja, aki korábban a manchesteri rendőrségnél (Greater Manchester Police) dolgozott.

${ }^{448}$ Bővebben lásd Ministry of Attorney General: End Hate Crime. http://www.ag.gov.bc.ca/prosecutionservice/pdf/EndHateCrimes_booklet.pdf
} 
rendszerekre is találunk példákat. Azonban nincs egyetlen tökéletesnek nevezhető megoldás sem. Egy jogszabály akkor válik a leghatékonyabbá és egyben kikényszeríthetővé, ha figyelemmel van az adott ország történelmi tapasztalataira, társadalmi berendezkedésére. Azonban a meglévő tapasztalok mindképp vezérfonalul szolgálhatnak a hatékony szabályozási háttér kialakítása során.

Ugyanakkor fontos, hogy a jogszabály a joggyakorlatba is átkerüljön, és valamennyi érintett (áldozatok, potenciális elkövetök és a bünüldöző szervek) tisztában legyen a szabályozással, és elkerüljék a jogszabályok kiüresedését. A büntetőjog visszatartó ereje akkor érvényesül igazán hatékonyan, ha a vonatkozó szabályokról a társadalom széles rétegei, így különösen a potenciális elkövetök is értesülnek. Sokat hangoztatott érv a szakirodalomban, hogy a gyülölet-büncselekmények „üzenet-büncselekmények”, amelyekkel az elkövetők a támadott kisebbségi csoport valamennyi tagjának üzennek, ${ }^{449}$ és hogy a gyülölet-büncselekményekkel szembeni fellépés egyik fontos feladata, hogy hasonlóan erélyes, de ellentétes üzenetet fogalmazzon meg a társadalom részéről: a kisebbségi csoportok kirekesztése, bántalmazása nem elfogadható. Ugyanakkor a sértettektől és a tanúktól is csak akkor várható el az ilyen esetek bejelentése, ha tisztában vannak a bűncselekmény jogi megítélésének súlyával, és biztosak lehetnek abban, hogy bejelentésüket a bünüldöző szervek komolyan veszik. A gyülölet-büncselekmények elleni fellépés terén a jogszabályi hiányosságoknál is súlyosabb problémát jelent, hogy a jogalkalmazó szervek, elsősorban a rendőrség, nem képes a vonatkozó jogszabályokat a gyakorlatban hatékonyan alkalmazni. A gyülöletbűncselekmények sajátosságai (elsősorban a motiváció bizonyíthatóságának nehézsége és az áldozati csoportok fokozott érzékenysége) számos ország rendőrségét arra vezette, hogy külön irányelveket fogadjanak el a gyülölet-büncselekményekkel kapcsolatos nyomozásokra. A megfelelő képzési programokkal pedig csökkenthetőek, illetve/kiküszöbölhetőek a bünüldöző szervek körében tapasztalható legnagyobb problémák, mint például a tendenciózus “félreminősítés". Emellett, mint látható megfelelő információs kampányokkal biztosítható, hogy a gyülöletbüncselekményekkel kapcsolatos szabályokról valamennyi érintett értesüljön. A társadalom egészét megcélzó televíziós, online és óriásplakát-kampányok, amelyek a bejelentésének fontosságát is hangsúlyozzák, nagyban hozzájárulhatnak a jelentési hajlandóság növeléséhez. A jelentési hajlandóságot növelő rendőrségi programokra,

${ }^{449}$ Lásd például Perry-Olsson 2009. és Lim 2009. 
szervezeti megoldásokra az Egyesült Királyság például számos jó és követendő példával szolgál. A gyakorlati tapasztalatok azt mutatják, hogy ezek a módszerek hatékonyak, és egyre több állam alkalmazza ezeket a bejelentési formákat, így például Kanadában is igyekeznek az angol mintát követni.

Végül mind a jogalkotással, mind a jogalkalmazással jelentős kölcsönhatásban van az adatgyüjtési rendszer hatékonysága. A gyülölet-büncselekmények elterjedtségére és hatósági kezelésére vonatkozó megbízható adatok összegyüjtése, elemzése és nyilvánosságra hozatala alapvető jelentőségü mind a széles társadalom, mind az érintett hatóságok tudatformálásához. Mint Németországban is láthattuk, az adatgyüjtési és így az egész gyülölet-büncselekményekkel kapcsolatos diskurzus felélénkülését az áldozatokra vonatkozó statisztikával kapcsolatos újságcikkek váltották ki, felhívva a figyelmet a probléma valós súlyára. Az adatgyüjtés hatékonyságát és a hatékony fellépést nagyban segítheti, ha a nemzetközi normáknak megfelelö, átfogó, statisztikai adatgyüjtési célra használható gyülölet-büncselekmény meghatározást vezetnek be; az elöítéletes indítékra vonatkozó gyanú regisztrálható a statisztikai rendszerben; az elöítéletes indítékot áldozati csoportok szerinti lehet regisztrálni; valamint, ha éves jelentés készül a gyülölet-büncselekményekkel kapcsolatos statisztikákból, amely kitér az esetek előfordulásának számára, a feljelentések sorsára és a kiszabott szankciókra is.

A fent ismertetett megoldások irányt mutathatnak a magyar jogalkotók és jogalkalmazók számára is. Természetesen az eltérő társadalmi és kulturális háttér eleve gátat szab egyes megoldások implementálásának. De az oly sokszor hangsúlyozott civil szervezeti és rendőrségi együttmüködés lehetővé tenné a rendszeres kommunikációt és a tapasztalatcserét. A civilek áldozatokkal kapcsolatos tapasztalatai és a rendőrség szervezeti és eljárási szakmai tudásának ötvözése eredményeként lehetővé válna egy áldozatközpontú megközelítés kialakítása figyelembe véve az esetleges szervezeti és eljárási akadályokat. 


\section{A hazai szabályozásáról és jogalkalmazásról}

Jelen fejezet célja, hogy átfogó képet nyújtson a gyülölet-büncselekményekkel kapcsolatos hazai tapasztalatokról, a jogalkotás, a jogalkalmazás, a hivatalos adatgyüjtési rendszer és a jó gyakorlatok szempontjából.

\section{Jogalkotás}

Magyarországon a ,gyülölet-büncselekmény” mint fogalom nem jelenik meg a büntető kódexben, de vannak olyan tényállások, amelyek az elöítélet-motivációt magukban foglalják valamilyen formában.

A dolgozat korábbi fejezeteiben használt büntető-jogtudomámyi fogalmak alapján a szabályozás négy típust követhet: önálló tényállás, minősített eset, büntetési tételt emelő rendelkezés és súlyosító körülmény. Ezekből csak néhány található meg a magyar jogrendszerben. Sui generis tényállás a Btk. 216. §-ában szereplő közösség tagja elleni erőszak. Minősített körülményként az előítélet motiváció önmagában nem szerepel, de vannak olyan büncselekmények, amelyek minősített körülményként tartalmazzák az aljas indokból elkövetést. ${ }^{450} \mathrm{Az}$ aljas indokból elkövetés ugyan magában foglalja az előítélet motivációt, de nem tekinthető az előítélet motivációval kapcsolatos kizárólagos minősítő körülménynek, mivel annak az elöítélet motiváció csupán egy eleme.

A bírói gyakorlat is konzekvensen arra az álláspontra helyezkedik, hogy az aljas indok magában foglalja az előítélet-motivációt. Így például a Debreceni Törvényszék kétséget kizáróan megállapította, hogy a vádlott cselekménye aljas indokból, célból történt, tekintettel arra, hogy az ölési cselekményt a homoszexuális személyek iránti gyülölete motiválta, melyet az ölési cselekmény során általa tett nyilatkozat (,,dögölj meg, buzi, köcsög!’”) alátámaszt. ${ }^{451}$ De ugyanerre az álláspontra helyezkedett a Budapest Környéki Törvényszék a romák elleni gyilkosságok ügyében, ahol rámutattak a rasszista motivációra az aljas indokból elkövetésen belül. A tanácsvezető bíró hangsúlyozta, hogy erkölcsileg megengedhetetlen, és emiatt súlyosabban minősül, ha valakiket akár

${ }^{450}$ A Btk. az alábbi tényállások keretében szabályozza az aljas indokból elkövetést: emberölés [Btk. 160. $\S$ (2) bek. c) pont]; testi sértés [Btk. 164. § (4) bek. a) pont és (6) bek. a) pont]; személyi szabadság megsértése [Btk. 194. § (2) bek. b) pont]; rágalmazás [Btk. 226. § (2) bek. a) pont]; jogellenes fogva tartás [Btk. 304. § (2) bek. a) pont]; és az alárendelt megsértése mint katonai büncselekmény [Btk. 449. $\S$ (2) bek. a) pont].

${ }^{451}$ Háttér Társaság által kutatási célból átadott ügyek. Debreceni Törvényszék, 25.B.48/2013/23. szám. 
cigány, akár más nemzetiséghez tartozásuk miatt ér erőszak. A bíróság indokolása alapján az elítéltek előéletéből megállapítható volt, hogy személyiségükbe mélyen beivódott a kirekesztő gondolkodásmód, és céljuk a cigány etnikumhoz tartozók megrendszabályozása, megfélemlítése volt. A bíróság tehát - a nemzetközi emberi jogi elvárásoknak megfelelően - kellő hangsúlyt fektetett ítéletének indokolásában a cigány emberek elleni támadás-sorozat rasszista indítékára, ezzel első fokon megtette a tőle elvárhatót a magyarországi cigányok kirekesztése ellen. ${ }^{452}$

Emellett büntetési tételt emelő rendelkezést és súlyosító körülményt nem tartalmaz a magyar büntető kódex. Kifejezett súlyosító körülményt ugyan nem tartalmaz, de a bírói gyakorlat alapján az elöítéletes elkövetés a büntetés kiszabásánál súlyosító körülményként értékelendő.

Bizonyos szempontból a népirtás (Btk. 142. §) és az apartheid (Btk. 144. §) tényállását is a gyülölet-büncselekményekkel kapcsolatos rendelkezések körébe sorolhatjuk, de ezek nem képezik jelen írás fókuszát. Ugyan szintén a közösségek védelmét hivatottak szolgálni, de olyan speciális jellemzőkkel bírnak, amelyek jelentős mértékben megkülönböztetik azokat a Btk.-ban szabályozott más büncselekményektől, illetve nincs is vonatkozó hazai joggyakorlat. Ezen cselekmények az adott csoport teljes vagy részleges megsemmisítésére, elnyomására irányulnak, volumenükben teljesen eltérnek más büncselekményektől. Az emberiesség elleni büncselekmények között szerepelnek, jogi tárgyuk az emberiség legalapvetőbb morális értékei, adott esetben az emberiség békéje és biztonsága. ${ }^{453}$ Mindebből kifolyólag pedig egészen más jogalkotási és eljárásjogi szempontok érvényesülnek e cselekményekre vonatkozóan, mint például a közösség tagja elleni erőszakra.

Ehhez képest vannak olyan büncselekmények, amelyek önmagában a gyülölet kifejeződését büntetik, így azokat legfeljebb a gyülölet-büncselekmények speciális típusának tekinthetjük, így nem is képezik jelen írás és a kutatás fókuszát. Ide tartozik például a gyülöletbeszéd (uszítás, izgatás), ${ }^{454}$ tehát azon megnyilvánulások, amelyekkel valaki - általában elöítélettől, vagy gyülölettől vezérelve - a társadalom csoportjairól

\footnotetext{
${ }^{452}$ Társaság a Szabadságjogokért: A bírósás megtette dolgát, az állam még tétlenkedik, 2013. augusztus 6. http://tasz.hu/romaprogram/birosag-megtette-dolgat-az-allam-meg-tetlenkedik-0 (2014. december 6.)

${ }^{453}$ Lásd Görgényi Ilona [et al.]: Magyar Büntetöjog - Különös rész. Complex Kiadó, 2013, XIII. fejezet, Az emberiesség elleni büncselekmények.

${ }^{454}$ A magyar Btk. közösség ellni uszításként szabályozza (Btk. 332. §).
} 
vagy azok egyes tagjairól (a csoporthoz tartozásukra tekintettel) szóban vagy írásban olyan állításokat közöl, amelyek sértheti a csoport tagjait, és gyülöletet kelthetnek a társadalomban a csoporttal szemben. ${ }^{455}$ Noha a legtöbb jogrendszerekben, így a magyarban is a gyülöletbeszéd büncselekménynek számít, azonban e büncselekmények esetében hiányzik a gyülölet-büncselekmény fogalmának egyik lényegi eleme, az alapbüncselekmény (például testi sértés, garázdaság, rongálás stb.). Ehelyett a gyülölet kinyilatkoztatásának formáját rendelik büntetni.

A gyülöletbeszéd ilyen jellegü sajátosságát osztják még a következő tényállások, ${ }^{456}$ amelyeket szintén legfeljebb a gyülölet-büncselekmények speciális alakzatának tekintek: közösség elleni uszítás (Btk. 332. §), a nemzetiszocialista vagy kommunista rendszer büneinek nyilvános tagadása (Btk. 333. §), nemzeti jelkép megsértése (Btk. 334. §), önkényuralmi jelkép használata (Btk. 335. §). Ez a megkülönböztetés büntetőjogi értelemben a nem sajátképi és sajátképi gyülölet-büncselekmények megosztásra épül. ${ }^{457}$ Nem sajátképi a gyülölet-büncselekmények alapkategóriája, mivel ezeknek létezik "egyszerü” büncselekményi párjuk is, azaz akkor is megvalósulna valamilyen más bűncselekmény, ha a jogalkotó és a jogalkalmazó az elöítélet motívumot semmilyen szinten nem értékelné. Ezzel szemben a sajátképi büncselekmények képezik a gyülölet-büncselekmények speciális kategóriáját. Ezek jellemzően - individuális jogtárgysérelem hiányában - a köznyugalmat sértik. ${ }^{458}$

\subsection{A sui generis tényállás - a tényállás kialakulása}

Az elöítélet-vezérelte büncselekmény sui generis tényállásként elsőként az 1961. évi Btk. $^{459}$ 138. §-ában jelent meg. Nemzeti, népi, faji vagy vallási csoport elleni büncselekményt követett el, aki „valamely nemzeti, népi, faji vagy vallási csoport tagjának a csoporthoz való tartozása miatt súlyos testi vagy lelki sérelmet" okozott. A tényállás a Btk. XI., a béke és az emberiség elleni büncselekményeket tartalmazó

\footnotetext{
${ }^{455}$ Halmai Gábor által fogalommeghatározása alapján. Ld. Halmai Gábor: Kommunikációs jogok. Budapest: Új Mandátum, 2002. 114.

${ }^{456}$ A gyülöletbeszédet ilyen szempontból szintén tágan értelmezi Koltay András, és a kategóriához tartozónak tartja a nemzeti és önkényuralmi jelképekkel, valamint a holokauszttagadással kapcsolatos kérdéseket. Lásd Koltay 2013, 17.

${ }^{457}$ Ez a megkülönböztetés Szomora Zsolttól ered. Lásd: Szomora Zsolt: „Dogmatikai és alkotmányjogi megjegyzések a gyülölet-büncselekmények büntetőjogi szabályozásához” Belügyi Szemle, 2013/12. 3651 .

458 Uo. 38-39.

${ }^{459}$ 1961. évi V. törvény a Magyar Népköztársaság Büntető Törvénykönyvéről (1961-es Btk.).
} 
fejezetében szerepelt. A törvényhez füzött miniszteri indokolás szerint a tényállás bevezetésére a népirtás büntettének megelőzéséről és megbüntetéséről szóló ENSZ egyezmény ${ }^{460}$ által Magyarországra rótt nemzetközi kötelezettség miatt volt szükség. A miniszteri indokolás szerint ekkor még a tényállás az olyan támadásokkal szemben védte a védett csoport tagjait, amelyek a csoport tagjainak testi vagy lelki megkínzását célozták. ${ }^{461}$

Az 1978. évi Btk. ${ }^{462}$ hatályba lépésekor a vonatkozó tényállást változatlan formában fenntartották a 156. §-ban. A törvény miniszteri indokolása szerint az elkövető a csoport tagjának a csoporthoz való tartozása miatt okoz súlyos testi vagy lelki sérelmet, így tehát a büncselekmény elkövetése a csoport iránti gyülöletből, ellenséges érzésből fakad. ${ }^{463}$ A rendelkezés első jelentős módosítása 1996 júniusában lépett hatályba. ${ }^{464} \mathrm{~A}$ büncselekmény átkerült a személy elleni büncselekmények közé, és a büncselekmény elnevezését „nemzeti, etnikai, faji vagy vallási csoport tagja elleni erőszak"-ra változtatták. A módosítás hátterében az állt, hogy a kialakult bírói gyakorlat szerint a tényállást korábban szabályozó 156 . § nem volt alkalmazható olyan esetekben, amikor a büncselekmény sértettje egy konkrét személy volt, mivel a tényállás az emberiség elleni bűncselekmények között szerepelt, jogi tárgya az emberiség békéje, illetve a különböző nemzeti, népi, faji vagy vallási csoportok voltak. A jogalkotó ezt a problémát úgy küszöbölte ki, hogy nem a csoport, hanem a csoport tagja ellen irányuló magatartást rendelte büntetni. Emellett már nemcsak valamely társadalmi csoporthoz való tényleges tartozás, hanem az elkövető erre vonatkozó vélelme is elégséges lett a tényállás megállapításához. Végül újrafogalmazták az elkövetési magatartást is: korábban a súlyos testi vagy lelki sérelem okozása volt büntetendő, az új tényállás a bántalmazást és a kényszerítést tartalmazta, jelentősen bővítve ezzel a büntetendő magatartások körét. ${ }^{465}$

\footnotetext{
${ }^{460}$ Egyezmény a népirtás büntettének megelőzéséröl és megbüntetéséről (Convention for the Prevention and Punishment of the Crime of Genocide) U.N.T.S. No. 1021, Vol. 78, 1951, 277. (Magyarországon kihirdetette a 1955. évi 16. törvényerejü rendelet).

${ }^{461} \mathrm{Az}$ 1961. évi V. törvény 138. §-ához füzött Indokolás. In: A Magyar Népköztársaság Büntető Törvénykönyve. Budapest: KJK, 1962. 245.

462 1978. évi IV. törvény a Büntető Törvénykönyvröl (1978. évi Btk.).

${ }^{463} \mathrm{Az}$ 1978. évi IV. törvény 156. §-ához füzött Indokolás. In: Büntető Törvénykönyv. Budapest: KJK, $1979,215$.

464 1978. évi Btk. 174/B. \&

${ }^{465}$ Átol [et al.] 2013. 81-82.
} 
2009-ben módosult a Btk. 174/B. § megnevezése közösség tagja elleni erőszakra, és ezzel párhuzamosan kiterjesztették a büntetőjogi védelmet a „lakosság egyes csoportjaira”, ezzel pedig nyílt listás gyülöletbüncselekmény-szabályozásra váltott át a magyar jogalkotó. A korábbi zárt végü listát tartalmazó tényállás csupán a nemzeti, etnikai, faji vagy vallási csoportok tagjait védte, így kirekesztette a büntetőjogi védelem köréböl például a szexuális irányultságot, nemi identitást, fogyatékosságot és más olyan csoportokat, amelyek gyakran válnak gyülöletvezérelte büncselekmény áldozatává. Erre mutatott rá a törvény indokolása is, amely szerint „, a több mint tízéves jogalkalmazási tapasztalat bebizonyította, hogy nem csak e csoportok tagjai vannak kitéve támadásnak a csoporthoz való vélt vagy valós tartozás okán. A társadalomban további csoportosulások, közösségi formák is léteznek, amelyek tagjaival szembeni diszkriminatív és eröszakos megnyilvánulásokat hasonlóan szigorú büntetéssel kell fenyegetni" ${ }^{466}$ Végül fontos változás volt, hogy a közösség védelmére alkotott szabály kereteit kiterjesztették az előkészületre is. Ugyanakkor fontos kiemelni azt a körülményt, hogy ezzel a módosítással a kisebbségvédő funkciója a szabályozásnak háttérbe szorult.

2011 májusában a tényállás kiegészült az (1a) bekezdéssel, amely szerint három évig terjedő szabadságvesztéssel büntetendő, aki mással szemben valamely nemzeti, etnikai, faji, vallási csoporthoz vagy a lakosság egyes csoportjaihoz tartozása vagy vélt tartozása miatt olyan, kihívóan közösségellenes magatartást tanúsít, amely alkalmas arra, hogy riadalmat keltsen. Ezen módosítás „Lex Gyöngyöspata” néven terjedt el a köztudatban, mert egy nagy visszhangot kiváltó incidens-sorozat, a gyöngyöspatai romák elleni szélsőséges, megfélemlítő fellépésre szánták válaszul. A törvény miniszteri indokolása szerint a módosításra azért volt szükség, mert „elszaporodtak azok a magatartások, amelyek ugyan nem érik el a közösség tagja elleni erőszak tényállásában jelenleg szankcionált erőszak mértékét, azonban az egyes nemzeti, etnikai, faji, vallási csoportok tagjaiban jogos félelmet, riadalmat keltenek, ezzel etnikai feszültséget szítva". ${ }^{467}$

2012. június 25-én az Országgyülés elfogadta az új Büntető Törvénykönyvet, ${ }^{468}$ amelyben a tényállás elnyerte mai formáját. ${ }^{469} \mathrm{Az}$ új Btk. többek között a

\footnotetext{
466 A közrend, valamint az igazságszolgáltatás müködésének védelme érdekében szükséges egyes törvénymódosításokról szóló T/6218. számú törvényjavaslat indokolása.

467 A Büntető Törvénykönyvről szóló 1978. évi IV. törvény módosításáról szóló T/2990. számú törvényjavaslat indokolása, Általános indokolás.

468 2012. évi C. törvény a Büntető Törvénykönyvröl (Btk.).
} 
gyülöletvezérelte büncselekmények terén is változásokat hozott. A Btk. elfogadásának folyamatában a GYEM részletes javaslatokat készített a gyülöletvezérelte büncselekmények hatékonyabb szabályozása érdekében. ${ }^{470}$ Kitértek többek között a védendő csoportok meghatározásának problémáira és a pontosítás lehetséges formáira, így pl. a nyílt lista valamint a zárt lista alkalmazásának lehetőségére, amely utóbbi álláspontjuk szerint kiiktatta volna a jogalkalmazásbeli bizonytalanságokat, illetve kizárta volna, hogy olyan csoportok is védelmet kapjanak, amelyeket nem személyiségük lényegi vonásaként meghatározott védett tulajdonság köt össze. A javaslat sok egyéb kérdés mellett rátért az elöítélet által motivált, aljas indokból való elkövetés körébe tartozó büncselekmények problémájára. A civil szervezetek tapasztalatai azt mutatják, hogy a jogalkalmazók sok esetben nem ismerik fel a gyülöletmotivációból elkövetett cselekményeket, illetve problémásnak látták, hogy nem mutathatók ki az aljas indokból elkövetett büncselekményeken belül az egyes indítékok, így a gyülölet-büncselekmények számára vonatkozóan sem állnak rendelkezésre adatok.

Az új Btk. a korábban nevesített csoportok mellett, a „lakosság egyes csoportjai” fordulat megörzésével újabb, az elöítéletes indítékból elkövetett támadásoknak gyakran kitett társadalmi csoportokat - szexuális irányultság, nemi identitás, fogyatékosság szerinti csoportokat - is nevesít, amely módosítás érdekében a GYEM intenzív

${ }^{469}$ Közösség tagja elleni erőszak

216. § (1) Aki más valamely nemzeti, etnikai, faji, vallási csoporthoz vagy a lakosság egyes csoportjaihoz tartozása vagy vélt tartozása, így különösen fogyatékossága, nemi identitása, szexuális irányultsága miatt olyan, kihívóan közösségellenes magatartást tanúsít, amely alkalmas arra, hogy az adott csoport tagjában riadalmat keltsen, büntett miatt három évig terjedő szabadságvesztéssel büntetendő.

(2) Aki mást valamely nemzeti, etnikai, faji, vallási csoporthoz vagy a lakosság egyes csoportjaihoz tartozása vagy vélt tartozása, így különösen fogyatékossága, nemi identitása, szexuális irányultsága miatt bántalmaz, illetve erőszakkal vagy fenyegetéssel arra kényszerít, hogy valamit tegyen, ne tegyen vagy eltürjön, egy évtől öt évig terjedő szabadságvesztéssel büntetendö.

(3) A büntetés két évtől nyolc évig terjedő szabadságvesztés, ha a közösség tagja elleni erőszakot

a) fegyveresen,

b) felfegyverkezve,

c) jelentős érdeksérelmet okozva,

d) a sértett sanyargatásával,

e) csoportosan vagy

f) bünszövetségben

követik el.

(4) Aki a közösség tagja elleni erőszakra irányuló előkészületet követ el, vétség miatt két évig terjedő szabadságvesztéssel büntetendő.

470 GYEM: Az új Büntetö törvénykönyv gyülölet-büncselekményekre vonatkozó rendelkezéseinek kialakitása során figyelembe veendö szempontok. 2012. február 22. (http://gyuloletellen.hu/sites/default/files/hatteranyag_2012-02-22.pdf); GYEM: Javaslatok az új Büntetö Törvénykönyv gyülölet-büncselekményekre vonatkozó szabályozására. 2012. március 6. (http://gyuloletellen.hu/sites/default/files/btkvelemeny_2012-03-06.pdf); GYEM: Javaslatok az új Büntető Törvénykönyv gyülölet-büncselekményekre vonatkozó szabályozására (parlamenti vita). 2012. május 3. (http://gyuloletellen.hu/sites/default/files/btkvelemenyparl_2012-05-03.pdf). 
lobbitevékenységet folytatott. A civil szervezetek álláspontja szerint jelzésértékü a védett csoportok körének ilyen jellegü bővítése, mert fontos üzenetet küld a jogalkalmazók és az egész társadalom felé azzal kapcsolatban, hogy ennek a három csoportnak az ellenük irányuló elöítéletesség miatt kiemelt jogi védelemben kell részesülnie. A törvény indoklása szerint egyrészt figyelembe vették a nemzetközi ajánlásokat, másrészt azt, hogy e csoportokkal szemben megnövekedett a gyülöletbűncselekmények száma.

Emellett részben újrafogalmazták a 2011-ben bevezetett garázda jellegü elkövetési magatartást, ezzel is egyértelművé téve, hogy a tényállás megállapításához elég, ha a kirívóan közösségellenes magatartás az adott társadalmi csoport tagjaiban alkalmas a riadalom kiváltására, ugyanakkor nem szükséges, hogy a kihívóan közösségellenes magatartás kifejezetten egy konkrét személy ellen irányuljon. Az indokolás külön is kitér arra, hogy az (1) bekezdés büntetni rendeli a vagyon ellen irányuló magatartásokat is, amelyek adott esetben például a rongálással halmazatban állapíthatóak meg. ${ }^{471} \mathrm{~A}$ közösség tagja elleni erőszak előkészületének büntethetőségét az előzetes tervek ellenére mégsem törölték el. Végül a bántalmazással vagy kényszerítéssel elkövetett közösség tagja elleni erőszak büntetési tételét megemelték öt évig terjedő szabadságvesztésről egytől öt évig terjedő szabadságvesztésre. Azonban ez sem ellensúlyozza azt, hogy olyan mértékben kitágították a tényállást, hogy azzal lényegében feloldották a kisebbségvédő funkciót a többi lakossági csoport védelmében. Ez a progresszió esetleg támogatható az antidiszkriminációs szabályozásban, de a büntetőjogban, annak értékjelző és végső megoldás jellege miatt a védendő és ténylegesen támadott csoportok számára inkább visszalépést jelent, mivel nagyobb absztrakciós képességet vár el az összes jogalkalmazótól.

A Btk. tervezetének társadalmi vitára bocsátásakor az alapvető jogok biztosa is lényeges kérdésekben foglalt állást a Btk. tervezete kapcsán megfogalmazott véleményében. ${ }^{472}$ Elismerte, hogy az elmúlt években egyre nagyobb arányban jelentek meg Magyarországon a rasszista indítékú, kisebbségellenes elöítéletből, a kirekesztő gondolkodásmódból fakadó gyülölet-cselekmények, amelyek nem csak az érintett

\footnotetext{
${ }^{471}$ A Büntető Törvénykönyvről szóló T/6958. számú törvényjavaslat indokolása

472 Alapvető jogok biztosának javaslatai az új Büntető Törvénykönyv tervezetének társadalmi vitára bocsátásakor. Közérdekü adatigénylés keretében a Háttér Társaság által megkért level. Hiv.szám: XXBKFO/47/2012.
} 
kisebbségi közösségek, de a társadalom minden józanul gondolkodó tagja biztonságérzetének megrendítésére alkalmasak. Éppen ezért javasolta, hogy Magyarország is az EBESZ által is javasolt kombinált szabályozási modellre térjen át amelyet például az Egyesült Királyságban is alkalmaznak. Eszerint hatékonyabb jogi kereteket biztosítana, ha a speciális, önálló tényállások formájában szankcionált cselekmények mellett „általános” minősítő körülményként határoznák meg a gyülöletmotívumot. A biztos szintén rámutatott, hogy a tervezett rendelkezések nem foglalnak magukban minden olyan elkövetési magatartást, amelyek a gyakorlatban felmerülhetnek a „védett csoportok" tagjaival szemben. Annak érdekében, hogy elkerülhető legyen a speciális tényállásokkal való átfedés, a gyülöletmotívum feltüntetését javasolta az emberölés, a zaklatás és a rongálás tényállásokban, ${ }^{473}$ valamint jelezte, hogy nem csak a személyek elleni, hanem a tulajdon elleni büncselekményeknek is lehet gyülölet-büncselekmény jellege. Végül a nyílt végü listával kapcsolatos sokszor hangsúlyozott problémákra is rámutatott, miszerint a „lakosság egyes csoportjai” kifejezés olyan tág kereteket biztosít a jogalkalmazónak, amely ellentétes lehet az eredeti jogalkotói szándékkal.

\subsection{A hatályos tényállás - Btk. 216. $\S$}

A továbbiakban a közösség tagja elleni eröszak tényállását elemzi részletesen a dolgozat, amely ismertetésre a későbbi jogalkalmazást elemző résznél támaszkodik.

A tényállás az Emberi méltóság és egyes alapvetö jogok elleni büncselekmények c. fejezetben szerepel a védett jogi tárgy az emberi méltóság ${ }^{474}$ azon aspektusa, hogy az „egyén félelem nélkül élhessen meghatározott társadalmi, lakossági csoporthoz tartozás mellett”. ${ }^{475}$ A Kúria álláspontja azzal egészíti ki, hogy a védett jogi tárgy „a diszkrimináció nélküli együttéléshez füzödö társadalmi érdek. Az a rendeltetése, hogy senkit ne érhessen bántalmazás, vagy bántódás amiatt, mert más népcsoporthoz tartozik." 476 A különös részi tankönyvek emellett - a 216. § (1) bekezdés esetében - a

\footnotetext{
473 Alapvető Jogok Biztosának Hivatala: AJB Projektfüzetek. A válság vesztesei - a paragrafusok fogságában projekt. 2013/3. (szerk.: Szajbély Katalin). 43-44.

${ }^{474}$ Szintén az emberi méltóságot határozza meg védett jogi tárgyként Kis-Hollán 2011, 56.

${ }^{475} \mathrm{Az}$ emberi méltóság és egyes alapvető jogok elleni büncselekmények in Karsai Krisztina (szerk.): Kommentár a Büntetö Törvénykönyvhöz (Kommentár a Büntetö Törvénykönyvröl szóló 2012. évi C. törvényhez). Budapest: Complex Kiadó, 2013. 452.

${ }^{476}$ Bfv.II.590/2012/18.szám
} 
köznyugalmat is védett jogi tárgyként jelölik meg. ${ }^{477}$

1.2.1. Btk. 216. $\S$ (1) bekezdés, a kihívóan közösségellenes magatartással megvalósított közösség tagja elleni eröszak

A tényállás szerint három évig terjedő szabadságvesztéssel büntetendő, aki mással szemben valamely nemzeti, etnikai, faji, vallási csoporthoz vagy a lakosság egyes csoportjaihoz tartozása vagy vélt tartozása, így különösen fogyatékossága, nemi identitása, szexuális irányultsága miatt olyan, kihívóan közösségellenes magatartást tanúsít, amely alkalmas arra, hogy az adott csoport tagjában riadalmat keltsen.

Tekintettel arra, hogy minden büncselekmény közösségellenes is, így a törvény az elkövetési magatartásnál - akárcsak a garázdaság tényállásánál - megkülönböztetésül annak kihívó voltát jelöli meg. A bírói gyakorlat szerint kihívóan közösségellenesség a magatartás, ha az elkövető a közösségi együttélés szabályait nyíltan, gátlástalanul, leplezetlenül semmibe veszi, feltünést kelt öntörvényü, jogsértő viselkedésével. ${ }^{478} \mathrm{~A}$ kihívó közösségellenesség jellemzője az is, hogy a terhelt az együttélés szabályainak leplezetlen, gátlástalan semmibevevésével ávalósítja meg a cselekményét. ${ }^{479}$ A kihívóan közösségellenes magatartásnak alkalmasnak kell lennie arra, hogy riadalmat keltsen, azonban a büncselekmény megvalósulásához nincs szükség arra, hogy a riadalom be is következzen. A kihívóan közösségellenes magatartás tanúsításával megvalósítható büncselekmény esetén nem szükséges, hogy az elkövető az ilyen magatartást a csoport tagja ellen tanúsítsa, elegendö, ha az dolog ellen irányul. A kihívóan közösségellenes magatartás megállapítása során mindig a cselekmény jellege és körülményei az irányadók, a potenciálisan szóba jöhető magatartások igen széleskörűek. Ezért a büntetőügyben eljáró hatóságoknak minden ügyben egyedi mérlegeléssel, az ügy összes körülményeire figyelemmel kell megállapítaniuk, hogy az adott magatartás eléri-e a közösségellenességnek a tényállásban megkívánt szintjét.

Abban az esetben, ha a dolog elleni erőszakkal elkövetett közösség tagja elleni erőszak nem fenyegetéssel kényszerítést valósít meg, akkor a Btk. 216. § (1) bekezdés szerint minősül. Így az elöítéletes indíték alapján tárgyak ellen kifejtett támadás nem rongálásként, hanem közösség tagja elleni erőszak büncselekményeként minősülhet. A

${ }^{477}$ Lásd pl. Karsai 2013, 452. ill. Kis-Hollán 2011, 56.

478 BH 2009. 171.

${ }^{479}$ BH 2007. 283. 
közösség tagja elleni erőszak enyhébb alapesetének ilyen irányú értelmezése tekintetében eltérő álláspontok léteznek és a jogalkalmazás sem egységes. Amíg civil jogvédő szervezetek - alternatív kommentárjukban is - ${ }^{480}$ konzekvensen ekképp értelmezik a tényállást, addig például a Közigazgatási és Igazságügyi Kerekasztal Emberjogi Munkacsoportját megosztja a kérdés. ${ }^{481}$ Az utóbbi évekből a jogalkalmazás is példával szolgál a dolog elleni erőszak közösség tagja elleni erőszak büncselekményét megvalósító értelmezésére. $\mathrm{Az}$ ügy - $\mathrm{az}$ egyébként nagy nyilvánosságot kapott - szegedi zsinagóga bejárati kapujának 2013 szeptemberi megrongálása. A kapu kovácsoltvas elemeinek csúcsaira 6 db szappant szúrtak, amelyekre filctollal köztudottan zsidó származású személyek nevét írták. Az ügyben közösség tagja elleni erőszak [Btk. 216. § (1) bek.] büncselekménye miatt folytatták az eljárást. ${ }^{482}$

Az első bekezdés szerinti tényállásra kevés példát találhatunk a jogalkalmazásban, olyan ügyet, amely eljutott a bírósági szakba pedig még kevesebbet. A tényállás ítélkezési gyakorlatban való megjelenésére egyetlen példáról van tudomásom, arról is a médián keresztuil. ${ }^{483} \mathrm{Az}$ ügyben három fiatal férfit ítélt el a Pesti Központi Kerületi Bíróság közösség tagja elleni erőszak büntette miatt 2013 májusában. Az eset a Zsidó Világkongresszus idején történt, amikor a húsz év körüli elkövetők a Deák téren félelemkeltő jelszavakat kiabáltak. Az eseményről távozó résztvevők ellen a későbbiekben fizikai erőszakot csak azért nem alkalmaztak, mert civil ruhás nyomozók megakadályozták öket. Az eljárásban megállapítást nyert, hogy az elkövetők olyan kihívóan közösségellenes magatartást tanúsítottak, amely alkalmas volt arra, hogy riadalmat keltsen. ${ }^{484}$

\subsubsection{Btk. 216. $§(2)$ bekezdés, a bántalmazással vagy kényszeritéssel elkövetett} közösség tagja elleni eröszak

A büncselekményt az követi el, aki mást valamely nemzeti, etnikai, faji, vallási csoporthoz vagy a lakosság egyes csoportjaihoz tartozása vagy vélt tartozása, így

\footnotetext{
480 Átol [et al.] 2013, 88.

481 GYEM által kezdeményezett közérdekü adatigénylés keretében rendelkezése bocsátott jelentés. ORFK: 2011-2013-as időszakra vonatkozó jelentés, 29000/6903-2/2015. Ált. 4.

${ }^{482}$ Uo. 4. Az ügyre vonatkozóan nem állnak rendelkezésre további adatok.

${ }^{483}$ Kulcsár Anna: Közösség tagja elleni eröszakért szabadságvesztés. http://mno.hu/belfold/kozossegtagja-elleni-eroszakert-szabadsagvesztes-1160147 (2013. október 30.)

${ }^{484}$ Lásd uo.
} 
különösen fogyatékossága, nemi identitása, szexuális irányultsága miatt bántalmaz, illetőleg erőszakkal vagy fenyegetéssel arra kényszerít, hogy valamit tegyen, ne tegyen vagy eltürjön. ${ }^{485}$

A büncselekmény elkövetési magatartása a bántalmazás vagy kényszerítés. Bántalmazás alatt a törvény, annak ellenére, hogy nem emeli ki, tettleges bántalmazást ért. ${ }^{486} \mathrm{~A}$ bántalmazás olyan személy elleni erőszakos cselekmény, amely a testet érinti (pl. ütés, rúgás, lökés, megfogás, leöntés, leköpés); megállapításához nem szükséges a testi sérülés, egészségkárosodás, a legkisebb mértékü személy elleni erőszakkal megvalósítható a tényállás. A közösség tagja elleni erőszak esetében csekély mértékben áll rendelkezésre bírói gyakorlat, így az elkövetési magatártások kapcsán többek között a hivatalos eljárásban elkövetett bántalmazás (Btk. 301. §) vagy a tettleges becsületsértés [Btk. 227. § (2) bekezdés] kapcsán kifejtettekre támaszkodhatunk, így például tettleges bántalmazás a kialakult bírói gyakorlat szerint más teste ellen irányuló, a testi épséget vagy a becsületet sértő támadás. ${ }^{487}$ A bíróság az elöbb említett döntésében rámutatott a terheltnek azon magatartása, hogy "az elítélt nyakát megragadta, fojtogatta", maradéktalanul kimeríti a tettleges bántalmazás fogalmát, függetlenül attól, hogy az milyen mérvü volt, okozott-e fájdalmat a sértettnek. A bíróság a tettleges becsületsértés értelmezése körében kifejtette, hogy ebbe a körbe tartozik az (egyszerü) arculütés, a sértett orrának felfricskázása, fülének meghúzása, a sértett leköpése, undorító vagy szennyes folyadékkal való leöntése, bemocskolása.

A személy elleni erőszak kérdéskörét alaposabban megvizsgálva, szükségképpen említést érdemel az alkalmazott erőszak mértéke az erőszak és fenyegetés alapjainak megértése érdekében. Az erőszak mértéke szempontjából megkülönböztethetünk akaratot bénító vagy kizáró erőszakot (vis absoluta) és az akaratot hajlító vagy korlátozó erőszakot (vis compulsiva). A vis compulsiva (az akarathajlító kényszer) tulajdonképpen fenyegetés, ${ }^{488}$ és csak a vis absoluta (az akaratmegtörö kényszer) az erőszak. Egyes álláspontok szerint vis compulsiva annyiban tér el a fenyegetéstől, hogy az utóbbinak az ütlegelés nem szükségszerü feltétele. Az erőszak és a fenyegetés

\footnotetext{
485 1978. évi Btk. 174/B. § (1) bekezdés

486 Így pl. a nemzeti, etnikai, faji vagy vallási csoport tagjai elleni erőszak kapcsán Kis-Hollán 2008, 120.

${ }^{487} \mathrm{BH}$ 2004. 269.

488 Így pl. az felelősséget kizáró vis compulsiva tekintetében Hollán Miklós „A cselekmény bünössége és az azt kizáró okok" In: Büntetőjog I., Az anyagi büntetőjog általános része. Büntetőjogi ismeretek a közszolgálati szakemberképzés számára (szerk.: Kis Norbert), Budapest-Pécs: Dialog Campus, 2011. 124.
} 
lényegében a kényszerítés két formája, és a kényszer nyilvánul meg testi erőszakban, vagy pszichikai ráhatással. ${ }^{489}$

Az erőszakot - amely általában tevőleges (aktív) és támadó jellegű magatartást jelent a Btk. Különös Részében foglalt törvényi tényállások egyébként, mint végrehajtási módot határozzák meg, melynek különböző változatai lehetnek. Vannak olyan törvényi tényállások, amelyek kizárólag személy ellen közvetlenül véghezvitt erőszakkal valósíthatók meg. Ilyennek tekinti az ítélkezési gyakorlat általában azokat a bűncselekményeket, amelyeknél a fenyegetésnek az élet vagy testi épség ellen irányulónak és közvetlennek kell lennie. Ezen felül azonban van olyan törvényi tényállás is, amely a személy elleni erőszakot kifejezetten tényállási elemként tartalmazza [pl. Btk. 284. $\$$ (2) bekezdés b) pontjában ${ }^{490}$ meghatározott fogolyzendülésben erőszak alkalmazásával való részvétel büntette]. Ezek a büncselekmények tehát még a dologról a személyre áttevődött erőszak alkalmazásával sem valósulhatnak meg. Természetesen a közösség tagja elleni erőszak nem ebbe a kategóriába tartozik a fentebb kifejtettek alapján.

A törvényi tényállások más részénél az ítélkezési gyakorlat megkívánja ugyan a személy elleni erőszakot, de nem tartja feltételnek a személy ellen közvetlenül alkalmazott kényszert. Ez a felismerés onnan adódik, hogy a személy elleni erőszak gyakran dolog közvetítésével valósul meg. Ha ugyanis a fizikai behatás közvetlenül a dologra irányul ugyan, de a dolog hatókörében személy is van, a dologgal szemben alkalmazott erőszak áttevődik a személyre, s az így alkalmazott erőszak a személy elleni erőszak sajátos, közvetetten érvényesülő formájává válik. A fentiekben jelzett feltételeken túlmenően az erőszak erőssége, kifejtésének módja és hatásfoka is különféleképpen érvényesül a Btk. Különös Részében foglalt egyes törvényi tényállások eseteiben. Így nyilvánvaló hogy pl. az erőszakos közösülés, a szemérem elleni erőszak, a rablás esetében az erőszaknak jóval lenyügözőbbnek, magasabb fokúnak, akaratot jobban megtörőnek kell lennie, mint a hivatalos személy elleni erőszak vagy az önbíráskodás esetében. ${ }^{491}$

489 Wiener A. Imre: Elméleti alapok a Büntetőtörvény Általános Része kodifikálásához, MTA Jogtudományi Intézetének kiadványa, Budapest, 2000. 96-97.

${ }^{490}$ Btk. 284. § (2) bekezdés b) pont meghatározott fogolyzendülés

${ }^{491} \mathrm{BH}$ 1987. 177. 
A 459. $§$ (1) bekezdés 4. pont értelmében erőszakos magatartásnak minősül a más személyre gyakorolt támadó jellegü fizikai ráhatás is, abban az esetben is, ha az nem alkalmas testi sérülés okozására. A dolog elleni erőszakkal elkövetett közösség tagja elleni erőszak akkor minősül a Btk. 216. § (2) bekezdés szerint, ha az fenyegetéssel kényszerítést valósít meg. Különben a dolog elleni erőszakkal történő elkövetés a Btk. 216. § (1) bekezdés szerint minősülhet. A dolog elleni erőszak gyakorlatban alkalmazható büntetőjogi fogalma: minden olyan személytől eredő, ingó vagy ingatlan dologra irányuló erőhatás, amely a dolog állagának sérelmével jár, és (vagy) helyzetét, állapotát, megszokott müködtetésétől, illetve használatától eltérő vagy rendeltetésével alapvetően ellentétes módon megváltoztatja. ${ }^{492}$ Korábban elterjedt volt az a téves felfogás, miszerint a dolog elleni erőszak mindig a dolog állagának bizonyos fokú sérelmével jár. Azonban határozottan le kell szögezni, hogy a dolog elleni erőszak veszélyessége nem kizárólag azon az eredményen mérhető le, hogy általa a dolog megsérül vagy megrongálódik. Hiszen az állagsérelem gyakori, de nem feltétlen velejárója a dolog elleni erőszaknak. A fogalomból következően a dolog elleni erőszak büntetőjogi fogalma igen széles cselekménykört ölel fel, és ide sorolhatunk egymástól sokszor alapvetően eltérő magatartásokat. Így például állagsérelemmel járó dolog elleni erőszaknak minősül az ajtó betörése vagy a kirakat bezúzása, és dolog elleni erőszaknak tekinthető az állagsérelem elmaradása esetén is például a gyengén zárt ablak benyomása. ${ }^{493}$

A Btk. 216. § (2) bekezdésében maghatározott büncselekmény II. fordulata lényegében azonos a Btk. 195. §-ába ütköző kényszerítés büntettének törvényi tényállásával, azzal a különbséggel, hogy elöbbinél a jelentős érdeksérelem okozását a törvény nem kívánja meg. Az ítélkezési gyakorlat szerint a kényszerítés törvényi tényállása alá esik minden olyan magatartás, amely erőszakkal vagy fenyegetéssel a sértett cselekvési szabadságát befolyásolja, amely öt arra készteti, hogy szabad akaratának meg nem felelően vagy éppen ellentétesen cselekedjék, valamint - ilyen értelemben - tegyen, ne tegyen vagy eltürjön valamit. Az elkövetési magatartás tehát valaminek a megtételére, meg nem tételére vagy eltürésére való kényszerítés. Az elkövetési mód - erőszak - lehet lenyügöző erejü, akaratot megbénító, de lehet akaratot hajlító is; a fenyegetésnek pedig

\footnotetext{
492 Tóth Mihály: “Gondolatok az »erőszak« büntetőjogi fogalmáról” Magyar Jog, 1981/6. 508.

493 Tóth Mihály: “A dolog elleni erőszak fogalmának értékelése a gyakorlatban” Belügyi szemle, 1981/12. 29-32.
} 
olyan súlyos hátrány kilátásba helyezésére kell vonatkoznia, amely alkalmas arra, hogy a megfenyegetettben komoly félelmet keltsen. ${ }^{494}$

A Btk. 459. § (1) bekezdés 7. pontjában foglalt értelmező rendelkezés a "fenyegetés" fogalmának általános meghatározását adja, de ettől a Btk. Különös Részében foglalt egyes törvényi tényállások eltérő fogalom meghatározást is tartalmaznak. Így a szexuális eröszak [Btk. 197. § (1) bek. a) pont] esetében a törvény az "élet vagy testi épség ellen irányuló közvetlen fenyegetés", ${ }^{495}$ azaz ún. kvalifikált fenyegetés fogalmát használja, amelynek a közösség tagja elleni erőszak esetében nem szükségszerüen kell fennállnia.

\subsubsection{Btk. 216. § (3) bekezdés, a közösség tagja elleni erőszak minösitett esetei}

A törvény minősített esetként határozza meg a fegyveresen [Btk. 216. § (3) bek. a) pont], felfegyverkezve [Btk. 216. § (3) bek. b) pont], jelentős érdeksérelmet okozva [Btk. 216. § (3) bek. c) pont], a sértett sanyargatásával [Btk. 216. § (3) bek. d) pont], csoportosan [Btk. 216. § (3) bek. e) pont], bünszövetségben való elkövetést [Btk. 216. § (3) bek. f) pont].

A fegyveres elkövetés fogalmát a Btk. 459. § (1) bekezdés 5. pontja határozza meg. Eszerint fegyveresen követi el a büncselekményt, aki löfegyvert, robbanóanyagot, robbantószert, robbanóanyag vagy robbantószer felhasználására szolgáló készüléket tart magánál, vagy a büncselekményt ezek utánzatával fenyegetve követi el.

A Btk. 459. § (1) bekezdés 6. pontja alapján, felfegyverkezve követi el a büncselekményt, aki az ellenállás leküzdése vagy megakadályozása érdekében az élet kioltására alkalmas eszközt tart magánál".

A jelentős érdeksérelem a Btk. 216. § (3) bek. c) pont alapján minősítő körülmény. A jelentős érdeksérelem fennállását mindig objektíve, de a konkrét eset valamennyi körülményeire konkretizálva kell vizsgálni, az érdeksérelem jellege, iránya, társadalmi megítélése alapján. Az érdeksérelem jelentős fokának megítélésénél azonban a sértett szubjektív érzékenységének nem lehet szerepe. ${ }^{496}$ Jelentős érdeksérelem egyaránt lehet

\footnotetext{
${ }^{494}$ BH 1987. 177.

495 BH 1983. 177.

${ }^{496}$ Lásd Kis-Hollán 2011, 56.
} 
a magánérdek vagy a közérdek sérelme, vagy akár ezek kombinációja is. Jelentkezhet személyi (erkölcsi) sérelemként: például a társadalmi megbecsülés, a nemi szabadság, a házastársi kapcsolat és a családi élet zavartalansága, vagy tudományos-szakmai tekintély vonatkozásában; de anyagi jellegü vonzattal is járhat. A közérdek sérelmét jelentheti a közügyek intézésével, közösségi érdekek képviseletével kapcsolatos cselekvési szabadság korlátozása is. Nem szükséges, hogy a jelentős érdeksérelem a tettes vagy bárki számára előnyt jelentsen, vagy a tettes legyen az, akinek számára esetleg az előnyt jelenti. Nem feltétel az sem, hogy a jelentős érdeksérelem a kényszerített személynél következzék be, sőt az a közérdekben is bekövetkezhet. ${ }^{497}$ Mivel a jelentős érdeksérelem a közösség tagja elleni erőszaknál minősítő eredmény, ezért elegendő, ha e körülményre az elkövető gondatlansága terjed ki. ${ }^{498}$ Az elkövető persze akkor is a minősített esetért felel, ha a jelentős érdeksérelem bekövetkezését a szándékossága fogja át.

A sértett sanyargatásával történő elkövetés körébe sorolható, ha a tettes a sértettet megkínozza vagy önmagának megalázására kényszeríti. ${ }^{499}$

A hazai szakirodalomban a minősített esetek szabályozására vonatkozóan is találhatunk kritikát. Ugyanis a 216. § (3) bekezdése komolyan aránytalanságot hoz létre azáltal, hogy úgy épül rá mindkét alapesetre, hogy azok súlya között a minősített tényállás nem tesz különbséget eltérő büntetési tételekkel. Emellett az első alapesetekre épülve egyes minősítő körülmények nem is értelmezhetők (pl. sértett sanyargatása, jelentős érdeksérelem). Ez a hiba már az 1978. évi Btk.-ban is szerepelt és a jogalkotó elmulasztotta kijavítani. ${ }^{500}$

A Btk. 459. § (1) bekezdés 3. pontja alapján „csoportos követik el a büncselekményt, ha az elkövetésben legalább három személy vesz részt”.

A bünszövetségen elkövetés fogalmát szintén az értelmező rendelkezések között tartalmazza a Btk., eszerint „bünszövetség akkor létesül, ha két vagy több személy

\footnotetext{
497 Lásd Busch Béla: „A személyiség büntetőjogi védelme, különös tekintettel a fegyveres testületek keretében megvalósuló deliktumokra II.” Rendészet és emberi jogok, 2011/2. 61-62.

$498 \mathrm{Az}$ eredményhez, mint a büncselekmény minősítő körülményéhez füzött súlyosabb jogkövetkezményekre magyarázatul lásd: Nagy Ferenc: A magyar büntetőjog általános része. Budapest: HVG-ORAC, 2008. 128-129.

499 Kis-Hollán 2011, 60.

${ }^{500}$ Lásd Karsai 2013, 454.
} 
büncselekményeket szervezetten követ el, vagy ebben megállapodik, és legalább egy büncselekmény elkövetését megkisérlik, de nem jön létre bünszervezet” [Btk. 459. § (1) bek. 2. pont].

\subsubsection{Btk. 216. § (4) bekezdés, a közösség tagja elleni eröszak elökélszülete}

A (4) bekezdés alapján a büncselekmény elökészülete büntetendő. A Btk. 11. §-a alapján elökészület miatt büntetendő, aki “a büncselekmény elkövetése céljából az ehhez szükséges vagy ezt könnyitö feltételeket biztosítja, az elkövetésre felhív, ajánlkozik, vállalkozik, vagy a közös elkövetésben megállapodik”. 501

Az előkészülettel kapcsolatban kiemelendő, hogy a jelenlegi jogértelmezési gyakorlat mellet problémás lehet a közösség elleni erőszakra irányuló elökészület és a közösség elleni uszítás (Btk. 332. §) elhatárolása. Az uszítás mint elkövetési magatartás 2004 óta létező extrém módon szük értelmezése miatt az erőszakra irányuló előkészülettől szinte alig elhatárolható. Emellett abszurd ellentmondást okoz a büncselekmények büntetési tételének összevetése is. Hiszen az egyén támadására közvetlenül irányuló előkészület büntetési tétele enyhébb, mint a köznyugalmat absztrakt módon veszélyeztető közösség elleni uszításé. Ezen - értelmezéssel fel nem oldható jogalkotói hiba miatt és figyelemmel az in dubio mitius elvére ${ }^{502}$ - a közösség tagja elleni erőszak előkészületét megvalósító személy terhére nem lehet megállapítani a közösség elleni uszítást. Ennek következtében a verbális uszítóval ellentétben az, aki kést is ragad, és az utcára indul a célba vett személyek megtámadására (közösség tagja elleni erőszak előkészületét megvalósítva), enyhébb büntetési tétel alá esik. ${ }^{503}$

A kihívóan közösségellenes magatartással megvalósított közösség tagja elleni erőszak elökészületet kapcsán alkotmányossági aggályok is felmerültek. ${ }^{504}$ Eszerint egy szabálysértésből - a tettesi motívum alapján - felminősített, nem szükségképpen erőszakos cselekmény elökészületének büntetendősége meglehetősen aránytalan, és az ultima ratio elvével aligha összeegyeztethető. A kialakult helyzet arra vezethető vissza,

\footnotetext{
501 A törvényben felsorolt öt magatartásra (büncselekményhez szükséges vagy azt könnyítő feltételeket biztosítása, felhívás, ajánlkozás, vállalkozás, valamint a közös elkövetésben való megállapodás) bővebben lásd Nagy 2008, 194-195.

502 Bővebben lásd: Mészáros Ádám: „Jogfilozófia és igazságosság a büntetőjogban. Az in dubio mitius elve" in Acta Publ. doct. jur. Tomus IV. Szeged, 2004. 391-413.

${ }^{503}$ Erre a jogalkotói hibára Szomora Zsolt hívta fel a figyelmet. Lásd Szomora 2013, 42.

${ }^{504}$ Lásd Szomora 2013, 46.
} 
hogy amikor a bekezdés elődjét 2011-ben törvénybe iktatták, az előkészület már büntetendő volt. Azonban a beiktatáskor a jogalkotó elmulasztotta figyelembe venni, hogy a korábbi állapothoz képest a tényállás szerkezetét megbontotta és ez az előkészületi rendelkezésre is hatással lehet. Az új Btk. kodifikálásakor ez korrigálható lett volna, de végül az előkészület mindkét bekezdés esetében megmaradt. ${ }^{505}$

\subsubsection{Halmazat}

Az alábbiakban a dolgozat néhány fópontban érinti a halmazati kérdéseket, rámutatva a joggyakorlatban és jogelméletben kialakult ellentmondásokra. A Btk. 216. § (1) bekezdés szerinti tényállás elkövetési magatartása kihívóan közösségellenes magatartás tanúsítása. A törvény miniszteri indokolása szerint „a kihívó közösségellenesség a közösségi együttélés szabályainak nyílt semmibevételét jelenti". ${ }^{506}$ A tényállás nyilvánvaló rokonságban áll a garázdasággal (Btk. 339. §), még inkább annak szabálysértési alakzatának tényállásával. ${ }^{507}$ Mivel a garázdaság szubszidiárius tényállás, a kétszeres értékelés tilalma és a specialitás elve miatt sincs helye a Btk. 216. § (1) bekezdéssel anyagi halmazatban történő megállapításának. Szintén a szubszidiárius jellegre tekintettel, amennyiben az elkövető dolog elleni erőszakot alkalmaz, ugyanakkor az elöítéletes indíték is megállapítható, a Btk. 216. § (1) bekezdés megállapításának van helye. A rongálás a Btk. 216. § (1) bekezdéssel akkor kerül halmazatba, ha a dolog elleni erőszak kimeríti a rongálás tényállását ${ }^{508}$ is. ${ }^{509}$

Nem egységes a joggyakorlat (sem a jogirodalom) a Btk. 216. § (2) bekezdésben szabályozott tényállás kapcsán abban az esetben, ha a bántalmazás testi sérülést vagy betegséget okoz. Az egyértelmü, hogy a bántalmazás megvalósulásához nincs szükség testi sértés vagy betegség okozására, ezért elméletileg megállapítható a testi sértés (Btk. 164. §) megfelelő alapesete (könnyü illetve súlyos testi sértés) és a közösség tagja elleni erőszak közötti anyagi halmazat. Bizonytalanságot okoz ugyanakkor, hogy mind a könnyü, mind a súlyos testi sértés esetében minősített esetként szabályozza a törvény az aljas indokot, amely a joggyakorlat értelmében az elöítéletes indítékot is magában

\footnotetext{
505 Bővebben lásd Szomora 2013, 46.

506 T/6958. számú törvényjavaslat indokolással - A Büntető Törvénykönyvről

507 2012. évi II. törvény 170. § Aki olyan kihívóan közösségellenes magatartást tanúsít, amely alkalmas arra, hogy másokban megbotránkozást vagy riadalmat keltsen, szabálysértést követ el.

508 Btk. 371. § (1) bekezdés. Aki idegen vagyontárgy megsemmisítésével vagy megrongálásával kárt okoz, rongálást követ el.

509 Átol [et al.] 2013, 87-88.
} 
foglalja. A GYEM által írt alternatív kommentár szerint ${ }^{510}$ a könnyü, illetve súlyos testi sértés elöítéletes indítékkal történő elkövetése esetében a halmazati büntetéskiszabási szabályok (Btk. 81. §) miatt indokolt a testi sértés megfelelő alapesete és a közösség tagja elleni erőszak halmazatban történő megállapítása. Amennyiben ugyanis az aljas indokból elkövetés minősített esete kerülne megállapításra, a kétszeres értékelés tilalma miatt természetesen nincs lehetőség a közösség tagja elleni erőszakkal halmazatban történő megállapításra. Ez viszont arra az eredményre vezetne, hogy a büntetési tétel a könnyü testi sértés minősített esetében alacsonyabb maradna, mint a közösség tagja elleni erőszak alapesete esetében, aljas indokból elkövetett súlyos testi sértés esetén pedig a közösség tagja elleni erőszak alapesetének maximális büntetési tételével azonos büntetés lenne kiszabható. ${ }^{511}$

A különös részi tankönyvek ${ }^{512}$ a halmazattal kapcsolatban úgy foglalnak állást, hogy a büncselekmény látszólagos halmazatban háttérbe szorul az aljas indokból elkövetett emberöléshez [Btk. 160. § (2) bek. c) pont I fordulat]. ${ }^{513}$ A büncselekmény Btk. 216. $\S$ (2) bekezdésben foglalt esete látszólagos halmazatban előtérbe lép az aljas indokból elkövetett könnyü testi sértéshez [Btk. 164. § (4) bek. a) pont 1. tétel] képest, a testi épség sérelme azonban súlyosító körülményként értékelhető. Ezzel szemben a Btk. 216. § (1)-(2) bekezdésben foglalt esetek látszólagos halmazatban háttérbe szorulnak az aljas indokból elkövetett súlyos testi sértéshez, a maradandó fogyatékosságot vagy súlyos egészségromlást okozó szándékos testi sértéshez, illetve a különös kegyetlenséggel elkövetett szándékos súlyos testi sértéshez [Btk. 164. § (6) bek. a), d-e) pont] képest. Utóbbi büncselekmény körében viszont súlyosító körülmény, hogy a tettes a cselekményt a sértett adott csoporthoz tartozása vagy vélt tartozása miatt valósítja meg, feltéve, hogy az aljas indokból elkövetés minősített esete nem kizárólag ezt értékeli. ${ }^{514}$ A büncselekmény minősített esetei látszólagos halmazatba előtérbe lépnek az aljas indokból elkövetett szándékos súlyos testi sértéshez, illetve a maradandó fogyatékosságot vagy súlyos egészségromlást okozó testi sértéshez, illetve különös kegyetlenséggel elkövetett súlyos testi sértéshez [Btk. 164. § (6) bek. a), d-e) pont] képest. Ezzel szemben látszólagos halmazatban háttérbe szorulnak az életveszélyt vagy halált okozó szándékos testi sértéshez [Btk. 164. § (8) bek.] képest. Ilyen esetben

\footnotetext{
510 Átol [et al.] 2013, 79-92.

511 Átol [et al.] 2013, 88-89.

512 Kis-Hollán 2011, 60.

513 Kis-Hollán 2011, 60.

${ }^{514}$ Kis-Hollán 2011, 60.
} 
súlyosító körülmény, ha a tettes a cselekményt a sértett csoporthoz tartozása vagy vélt tartozása miatt követi el. ${ }^{515}$

Azonban a fentiektől eltérő álláspontot is találhatunk a jogirodalomban. ${ }^{516}$ Eszerint egyrészt mind a bántalmazási, mind a kényszerítési fordulattal valóságos halmazatba kerülnek a testi sértés különbözö alakzatai azzal, hogy a testi sértés egyúttal nem értékelhető aljas indokból elkövetettként. Másrészt ezen álláspont szerint a halmazat a testi sértés valamennyi alakzatával (így az életveszélyt vagy halált okozó alakzatokkal) is valóságos. A testi sértés okozása ugyanis többlet tényállási elemet tartalmaz mindkét fordulathoz (bántalmazás, kényszerítés) képest. Az aljas indokból elkövetett súlyos testi sértés büntetési tétele megegyezik a közösség tagja elleni erőszak büntetési tételével, így a minősítéshez kapcsolt szankció nem képes kifejezni azt a többletet, amelyet a testi sértést nem feltételező közösség tagja elleni erőszak a tettes speciális motívumára tekintettel tartalmaz. Látszólagos halmazatról csak akkor lehetne beszélni, ha az aljas indokból elkövetett súlyos testi sértés büntetési tétele a halmazati büntetési meghaladná. Eszerint ugyanez a helyzet a maradandó fogyatékosságot, súlyos egészségromlást, életveszélyt vagy halált okozó testi sértéssel, ahol a tettes speciális motívumát semmi sem értékeli. A kényszerítési fordulat kapcsán példáként említik, hogy a testi sértés súlyosabb alakzatai más kényszerítési elemet tartalmazó büncselekményekkel is valóságos alaki halmazatba kerülnek (például szexuális erőszak, hivatalos személy elleni erőszak, önbíráskodás stb.). ${ }^{517}$

Valóságos halmazat álláspontját támasztja alá például egy nemrég született elsőfokú ítélet. Az Egymillióan a Magyar Sajtószabadságért ellenzéki szervezet 2012. okt. 23-i ünnepi rendezvénye és tüntetése mellett ellendemonstrációt tartott egy kb. 100 fös radikális jobboldali csoportosulás. Az Index hírportál egyik tudósítója munkatársával videófelvételt készített az ellendemonstráció résztvevőiről. Az ellendemonstráció kb. 10 résztvevője körülállta, lökdöste őket, és egyre indulatosabban kiabálták, hogy állítsák le a felvételt, és “menjenek vissza a metéltfarkúak közé”. A sértett pár perc után leengedte a kamerát a nyilvánvalóvá vált veszélyhelyzet miatt. Ezt követően két tüntető odalépett hozzá, és egyikük megütötte az orrát, amelynek következtében a sértett orra eltört. A sértett és tudósító társa kimenekültek az ellendemonstráció területéről. Az

\footnotetext{
515 Kis-Hollán 2011, 61.

516 Szomora 2013, 43.

517 Szomora 2013, 43.
} 
ellendemonstrálók egyértelmüen előítéletre utaló jelszavakat (“mocskos zsidók”, “Takarodjatok Izraelbe!") skandáltak a demonstráció során és közvetlenül a támadást megelőzően is és a sértettet is zsidó csoporthoz tartozónak vélték. A bíróság első fokon a Btk. 216. § (2) bekezdésbe ütköző és (3) bekezdés c) pont szerint minősülő közösség tagja elleni erőszak, és a Btk. 164. § (1) bekezdésbe ütköző és (3) bekezdés szerint minősülő súlyos testi sértés bűntette miatt állapította meg az elkövetők felelősségét. ${ }^{518}$

Mindezek fényében úgy tünik, hogy nem alakult ki egységes joggyakorlat a halmazati kérdések kapcsán. Azonban a jogirodalomra sem támaszkodhatunk az ellentmondások feloldása érdekében, hiszen ezen álláspontok is jelentősen eltérnek. Ezek alapján pedig akár azt is feltételezhetjük, hogy a problémák nem a jogalkalmazás szintjére, hanem a jogszabályokra vezethetők vissza és a jogalkotóra vár a kérdés megoldása. Mindezek tekintettel javasolt az értelmezések összhangját megteremtő lépéseket tenni.

\section{Jogalkalmazás}

\subsection{Hatáskör, gyülölet-büncselekmények elleni szakvonal és ügyészségi protokoll}

A jogalkalmazás kapcsán először a hatásköri szabályok tisztázása szükséges, ugyanis a közösség tagja elleni eröszakra az általánostól eltérő szabályok vonatkoznak. A hatáskör jogi szabályozását tekintve korábban a 3/2008. (I. 16.) IRM rendelet értelmében az 1978. évi Btk. 174/B. § (1)-(2) bekezdés (közösség tagja elleni erőszak), ${ }^{519}$ illetve az 1978. évi Btk. 269. § (közösség elleni izgatás) ${ }^{520}$ gyanúja alapján indult nyomozásokat a megyei (fővárosi) rendőr-főkapitányságok hatáskörébe utalta. A hatáskört újraszabályozó 25/2013. (VI. 24.) BM rendeletben - a GYEM által a véleményezési időszakban megfogalmazott írásbeli javaslattal összhangban ${ }^{521}$-a közösség tagja elleni erőszak elökészülete kapcsán indult nyomozások is megyei (fővárosi) hatáskörbe tartoznak.

Az ilyen ügyek nyomozására korábban nem voltak külön szervezeti egységek a rendőrfökapitányságokon belül. A föváros esetében a Btk. 216. §-a (közösség tagja elleni

\footnotetext{
${ }^{518}$ Az eset ismertetésére lásd: GYEM, Esetek, “Milla”. http://gyuloletellen.hu/node/40 (2015. április 21.)

${ }^{519}$ Btk. 216. § (1)-(2) bekezdés.

${ }^{520}$ Btk. 332. § Közösség elleni uszítás.

521 GYEM: A Gyülölet-büncselekmények elleni munkacsoport véleménye a rendörség nyomozó hatóságainak hatásköréröl és illetékességéröl szóló rendelet tervezetéröl, http://gyuloletellen.hu/sites/default/files/hataskorirendelet_2013-06-05.pdf (2013. szeptember 25.)
} 
erőszak) gyanúja alapján indult nyomozások 2012. augusztus 17-ét megelőző időszakban a Budapesti Rendőr-főkapitányság Szervezett Bünözés Elleni Főosztályának hatáskörébe tartoztak, a nyomozásokat ténylegesen végző Szervezett Bünözés Elleni Osztályt azonban 2012 augusztusában jogutód nélkül megszüntették. A megszüntetést követően az ilyen ügyek nyomozása a BRFK Szervezett Bünözés Elleni Főosztály Kábítószer Bünözés Elleni Szolgálatának a feladatkörébe került átsorolásra. Majd Budapest Rendőrfőkapitányának 17/2013. (III.04.) számú intézkedése alapján a BRFK Felderítő Főosztály hatáskörébe tartozott a nyomozás lefolytatása közösség tagja elleni erőszak és közösség elleni izgatás esetében. A hatályos 43/2013. (IX. 25.) BRFK intézkedés rendelkezik a BRFK nyomozó hatóságainak (szerveinek) hatásköréről és illetékességéről, amely szerint a Btk. 216. § esetében a BRFK Felderítő Főosztály rendelkezik hatáskörrel.

A 2012 januárjában az Országos Rendőr-főkapitányság, felismerve, hogy a gyülöletbüncselekmények nyomozása olyan speciális szakértelmet igényel, amely indokolja, hogy nyomozásokat speciálisan felkészített nyomozók végezzék, külön szakvonalat hozott létre a gyülölet-büncselekmények rendőrségi kezelésére. 2013-ra megyei szinten is kijelölték a szakvonal tagjait (megyénként egy föt, illetve a fóvárosban egy fö), akik mind részt vettek az EBESZ/DIEJH gyülölet-büncselekmények rendőri kezelésére vonatkozó képzésén. ${ }^{522}$ Annyi bizonyos, hogy három bűncselekmény tartozik a szakvonal hatáskörébe: közösség tagja elleni erőszak (Btk. 216. §), közösség elleni uszítás (Btk. 332. §), önkényuralmi jelképek használata (Btk. 335. §). ${ }^{523}$ A GYEM által megyei rendőr-főkapitányságoknak kiküldött levelekre érkezett válaszok alapján ${ }^{524}$ az derült ki, hogy a szakvonal tagjainak elsősorban kapcsolattartási feladati vannak, illetve adatszolgáltatási kötelezettségeknek tesznek eleget. A szakvonalak müködése nem egységes, fejlesztésük továbbra is folyamatban van. Ezért fordulhat elő a gyakorlatban, hogy egyes esetekben a szakvonal tagjai végzik a nyomozást, más esetekben tanácsadási feladatokat látnak, míg más esetekben ezen ügyek el sem jutnak a tagokhoz a hatáskörrel rendelkező nyomozó egységtől, de rendszerszerüség nem figyelhető meg a kérdésben.

522 Bővebben lásd EBESZ/DIEJI: Trainging Against Hate Crimes for Law Enforcement. Programme description. http://www.osce.org/odihr/tahcle?download=true (2013. november 25.)

523 Boross Zsigmond: „A gyülölet-büncselekmények aktuális magyarországi helyzete” Belügyi Szemle, 2013/12., 5-19.

5242013 májusában a GYEM levelet küldött a megyei rendőr-főkapitányságoknak, amelyben a szakvonal működésével kapcsolatban kértek információkat. A válaszok beérkezése még folyamatban van. 
A gyülölet-büncselekmények elleni szakvonal évente felméri az elöző évben kezdeményezett büntetőeljárásokat és erről jelentést tesz. A 2011-2013 időszakra vonatkozó jelentés $^{525}$ alátámasztja a fenti adatokat, miszerint a szakvonal három tényállást vizsgál: közösség tagja elleni erőszak (Btk. 216. §); közösség elleni uszítás (Btk. 332. §) és önkényuralmi jelkép használata (Btk. 335. §). Amint erre maga a jelentés is utal, a gyülölet-büncselekmények kategóriájába nemzetközi szinten is legfeljebb az első két tényállást sorolják, azonban a tapasztalatok alapján az elkövetői oldal átfedései és azonosságai alátámasztják a közös vizsgálat indokoltságát. Illetve a jelentés említi az aljas indokból elkövetést mint az elöítélet motivációt magában foglaló minősítő körülményt.

A szakvonal létrehozását mindenképp előremutató lépésnek tartom, azonban, mint látható a rendszer még nem teljesen kimunkált. Elősegítene a gyülöletbüncselekményekkel szembeni hatékony fellépést a tagok rendszeres továbbképzése a gyülölet-büncselekmények hatékony felderítésére a nemzetközi gyakorlatban elterjedt ún. indikátoralapú nyomozási technikáról, valamint a gyülölet-büncselekmények áldozatainak speciális szükségleteiröl. Emellett képzésekre és figyelemfelhívó programokra lenne szükség helyi szinten is, hogy a helyi rendőrök felismerjék a gyülölet-büncselekményeket és így az ügyek eljuthassanak a speciális szakértelemmel rendelkező szakvonal tagokhoz. Erre vonatkozóan a szakvonal jelentése is tesz megállapítások, nevezetesen indokolt lenne az elöítéletesség jeleinek megismertetése a végrehajtó állománnyal, képzések és tájékoztató anyagok eljuttatásával a helyes minősítés érdekében. ${ }^{526}$

Elösegítené a jelentési hajlandóságot, ha az áldozatok könnyen hozzáférhetnének a szakvonal tagjainak elérhetőségeihez és akár közvetlenül náluk is feljelentést tehetnének. Ez általánosságban történhetne a fénykép, elérhetőség közzétételével, nemzetközi minta alapján. Azonban jelen esetben csupán az elérhetőségek és nevek közzététele lehetséges, ugyanis egyes tagok a szakvonallal kapcsolatos feladatok mellett olyan tevékenységet is ellátnak, amely miatt fényképük nem hozható nyilvánosságra a rendőrség honlapján. Többek között ebből kifolyólag is a szakvonal kapcsán elsősorban azt kell eldönteni, hogy a szakvonal tagok kijelölésével egyben leveszik-e a vállukról az egyéb büncselekményekkel kapcsolatos feladatokat. Egyrészt a többes feladatkör a fenti

525 ORFK: 2011-2013-as időszakra vonatkozó jelentés, 29000/6903-2/2015. Ált.

${ }^{526}$ ORFK: 2011-2013-as időszakra vonatkozó jelentés, 29000/6903-2/2015. Ált. 
problémákhoz vezethet. Másrészt, ha a szakvonal megragad csupán például a kijelölés szintjén, azaz megjelölnek egy személyt megyei szinten, aki plusz feladatként megkapja a gyülölet-büncselekményekkel kapcsolatos feladatokat, akkor borítékolható, hogy a túlzott munkateher mellett képtelen lesz hatékonyan ellátni a feladatot. A szakvonal hatékony működéséhez az első lépés tehát, hogy megyei szinten legalább egy fö kizárólag a gyülölet-bűncselekményekkel szembeni egységes fellépésért felel.

A szakvonal álláspontom szerint az egyik kanadai modell alapulvételével, sokkal hatékonyabban müködhetne. A kanadai Edmonton városában (és még több városban is) alkalmazott megoldás egyfajta vegyes szervezeti modellt alkalmaz. Az egység tagjai folyamatosan figyelemmel kísérik a különböző helyi szélsőséges csoportok és személyek tevékenységét, segítséget nyújtanak, illetve maguk is végeznek nyomozati cselekményeket, különböző oktatási feladatokat látnak el, valamint a jó gyakorlatok kialakításában és terjesztésében is aktívan részt vesznek. Az egység tagjai alapvetően a belső informatikai rendszeren belül értesülnek a potenciális gyülöletbüncselekményekről. A járőrök, illetve a rendőrség más tagjai a rendszerben megjelölik, ha elöítélet-motiváció gyanúja merül fel, így a gyülölet-büncselekmények elleni egység azonnal értesül az esetről. ${ }^{527}$ Innentől kezdve kétféle alternatíva kínálkozik a nyomozati munkát illetően. Az esetek többségében csupán felügyeleti tevékenységet látnak el, de a nyomozást alapvetően az a körzet végzi, ahol a büncselekményt elkövették. Ilyen esetben a büntetőeljárást végig figyelemmel kísérik, szakmailag felügyelik, és segítséget nyújtanak a bizonyítékok gyüjtésében és. Ha az ügy mélyebb nyomozást igényel, akkor teljesen átveszik a nyomozást. ${ }^{528}$ A szakvonal tagjainak rendszeres találkozóival és kapcsolattartásával pedig egységessé tehető országos szinten a fellépés. Azonban kérdéses, hogy ez a magyar viszonyok között megvalósítható-e, föként abból a szempontból, hogy a szakvonal tagok leterheltsége - nem gyülölet-büncselekményekkel kapcsolatos feladataikból kifolyólag - lehetővé teszi-e ezen modell alkalmazását.

Szintén közérdekü adatigénylés ${ }^{529}$ keretében tájékoztatta az ügyészség a GYEM-et, hogy az EBESZ/DIEJH 2010-ben készült, a gyülölet motiválta bűncselekmények miatt

\footnotetext{
527 Az kérdéses, hogy utóbbi a magyar Robotzsaru rendszerben megoldható-e. A rendszer teljeskörü ismeretének hiányából fakadóan, a dolgozat keretei között nem tudunk állást foglalni.

${ }^{528}$ Forrás: Dan Woodall-lal, a gyülölet-büncselekmények elleni egység tagjával 2014 augusztusában doktori kutatásom céljából - folytatott interjúkból származnak a fent található, az edmontoni rendőrség gyülöletbüncselekmény-elleni egységére vonatkozó információk.

${ }^{529}$ Közérdekủ adatigénylés, Legfőbb Ügyészség, Ig. 42/8/2015. Legf.Ü. szám
} 
folytatott bűntetőeljárásokra vonatkozó munkaanyagának ${ }^{530}$ ajánlásai alapján ügyészségi protokollt állítottak össze, amelyet az ügyészségi belső Intranet hálózatba is feltöltöttek. Az ügyészségi belső Intranet hálózatba feltöltött jogszabályokhoz, belső normákhoz, szakmai, oktatási anyagokhoz, egyéb ügyészsége érintő információkhoz az ügyészi állomány szabadon hozzáférhet. A protokoll külföldi mintákra is kitérve részletesen ismerteti a gyülöletvezérelte büncselekmények kriminológiai és jogi természetét, felhívja a figyelmet a rasszista motívum mielőbbi felismerésének és megfelelő hangsúllyal történő kezelésének jelentőségére. Részletes iránymutatást ad a büncselekmény azonosítására, a nyomozásra, a vádképviseleti tevékenységre, valamint az áldozatvédelemre vonatkozóan is. A konkrét alkalmazásra egyelöre nem állnak rendelkezésre adatok. Így az sem világos, hogy a nyilvános hozzáférés egyet jelent-e azzal, hogy az ügyészi állomány tagjai tudnak-e a protokoll létéről, ha igen, alkalmazzák-e (kötelező vagy fakultatív jelleggel) a konkrét eljárásokban. Mindenesetre bíztató első lépés, hogy az ügyészség is felismerte a gyülölet-büncselekmények speciális jellegét és (egyelőre) szimbolikusan elismerte az e büncselekményeknek kijáró külön figyelem szükségességét.

\subsection{Jogalkalmazással kapcsolatos problémák}

A fenti szakvonallal kapcsolatos módszer alkalmazása azért is indokolt lenne, mert ami a jelenlegi gyülölet-büncselekményekkel kapcsolatos jogalkalmazást illeti súlyos rendszerszintű problémák figyelhetők meg, amint a rendelkezésre álló ügyek is alátámasztanak, és amint kiderül ez a GYEM által nemrégiben megjelent kiadványából. ${ }^{531}$ A civil szervezetek e kiadvány keretében 24 konkrét eseten keresztuil mutatnak rá az általuk kritikusnak tartott jogalkalmazási problémákra. Négy fó problémát különböztetnek meg, nevezetesen: alulminősítés, azaz amikor az elöítéletes motivációt figyelmen kívül hagyják az eljárásban, és ezért nem a Btk. megfelelő tényállását alkalmazzák, hanem egy enyhébben büntetendő cselekményt; rendőri intézkedés elmulasztása; nyomozati lépések elmulasztása; illetve a jogorvoslathoz való jog szük tere.

530 EBESZ/DIEJH: Prosecuting Hate Crimes. A Practical Guide. Varsó, 2014. munkaanyaga. http://www.osce.org/odihr/prosecutorsguide?download=true (2015. április 15.)

531 GYEM: Jogalkalmazási problémák a gyülölet-büncselekményekkel kapcsolatos eljárásokban. A Gyülölet-büncselekmények Elleni Munkacsoport (GYEM) tapasztalatai, 2014. http://gyuloletellen.hu/sites/default/files/ejk_esetosszefoglalo.pdf (2013. november 26.) 
A civil szervezetek tapasztalata azt mutatja, hogy a helyes rendőrségi minősítést a büntetőeljárási jogorvoslatok kimerítése révén érik el az esetek egy nem jelentéktelen részében. A probléma az, hogy e korrekciós mechanizmusnak másodlagosnak kellene lennie és elsősorban a rendőrségi minősítésnek kellene helyesnek lennie. A gyülöletbüncselekmények elleni fellépés terén a jogszabályi hiányosságoknál is súlyosabb problémát jelent, hogy a jogalkalmazó szervek, elsősorban a rendőrség, nem képes a vonatkozó jogszabályokat a gyakorlatban hatékonyan alkalmazni. Ha a rendőrség nem fordít megfelelö figyelmet a minősítő körülményre, elmulaszthatják megtenni azokat a később esetleg nem is pótolható - nyomozati lépéseket, amelyek a motiváció feltárásához elengedhetetlenek. ${ }^{532}$

A jogalkalmazásban tapasztalható problémákra a nemzeti és etnikai kisebbségi jogok országgyülési biztosa is rámutatott. ${ }^{533}$ Eszerint sok éve nem jelennek meg ezek a büncselekmények a rendörségi és ügyészségi statisztikákban, és ha vádemelésre, elítélésére mégis sor kerül, akkor a minősítés a „maradékcselekmény” alapján történik, azaz nem közösség tagja elleni erőszak miatt, hanem valamely olyan büncselekmény miatt, amely a az elöítélet-motivációt nem tartalmazza. A biztos álláspontja szerint évtizedek óta tapasztalható, hogy a büntetö-jogalkalmazási gyakorlat - rendőrségtôl a bíróságig - ebben a kérdésben egységesen passzivitást mutat, nem mutatja ki az előítélet motívumot, elfedi ezáltal e büncselekmények társadalomra veszélyességének legfontosabb vetületét. Ennek egyik oka lehet nehézkes bizonyítás, nem lehet kizárni azonban azt sem, hogy a rasszista motívumokat azért nem kutatják, mert félnek annak társadalmi hatásaitól. A felhívta arra a figyelmet, hogy a személy- és vagyon elleni, illetve a hivatali büncselekmények egy része esetében az elkövetés valódi motívuma láthatatlan marad, annak felderítésére, bizonyítására sem a nyomozó hatóságok, sem pedig az igazságszolgáltatás szervei nem mutatnak hajlandóságot, következésképpen jelenlétük évtizedek óta semmiféle formában nem érzékelhető a bünügyi statisztikákban.

A biztos által leírtakat támasztja alá amit Bócz Endre professzor, volt budapesti föügyész, az állam- és jogtudományok kandidátusa, negyven esztendős pályáját

\footnotetext{
532 Uo. 4-9.

533 Kállai Ernő, nemzeti és etnikai kisebbségi jogok országgyülési biztosának levele Navracsics Tibor, közigazgatási és $\quad$ igazságügyi $\quad$ miniszternek. $2011 . \quad$ április 5. http://www.kisebbsegiombudsman.hu/data/files/202083196.pdf (2015. június 26.)
} 
bemutató önéletrajzi könyvébe ír a gyülölet-büncselekmények „fejlődéstörténetérool”, rámutatva a rendszerben rejlő hibákra. ${ }^{534}$ Bócz szerint a 80-as években megindult előítélet-motiválta rongálások és testi sértések csúcsosodtak ki Magyarország elmúlt évtizedeinek legkegyetlenebb gyülölet-büncselekményeiben, a romák elleni támadássorozatban:

„A nyolcvanas évek második felében ütötte fel a fejét Budapesten egy olyan jelenség, amely a mai napig érezteti - egyre intenzívebben, és már nem csak budapesti viszonylatban - a hatását. Ismeretes, hogy már az 1960-as évektöl jöttek hazánkba egyre nagyobb számban külföldi - akkoriban fóként arab diákok. [...] Egy chilei menekültet arabnak nézett egy skinhead az esti, néptelen utcán. Megtámadta és pillangókéssel megsebezte a mit sejtö embert, aki hasztalanul mondta, hogy nem arab. Egy afrikai diákot megtámadott egy 4-5 föböl álló skineadcsoport, amint Budán a nyelvi elökészitöbe igyekezett; körbefogták, agyba-föbe verték és megrugdosták.[...]Több ügyben is vádat emeltünk a Btk. 156. §-a alapján. A bíróság igyekezett kitérni. Felhívott telefonon dr. Czili Gyula is, és le akart beszélni erről, mondván hogy ha ilyen itéletet hoznának, ez azt jelentené: pecsét alatt kijelentik, hogy Magyarországon létezik faji megkülönböztetés, s ezt s ezt politikai megfontolásból nyilvánvalóan nem tehetik. Az ügyeket a bíróságon sorra más minösitéssel zárták; rendszerint garázdaságnak, jobb esetben aljas indokból elkövetett súlyos testi sértésnek minősitették a büncselekményt. Kimondták inkább még azt a jogi képtelenséget is, hogy a »nemzeti, avagy faji csoporthoz tartozás« mint a bántalmazás indoka a törvényben szereplö »aljas indok«-hoz képest nem speciális. [...]. ${ }^{535}$

A minősítéssel kapcsolatos tévedések mellett megjelenő rendőri intézkedések elmulasztásának problémája inkább a gyülekezési jog kapcsán merült fel a civil szervezetek tevékenysége során. Arra világítottak rá az esetekkel, hogy gyakran olyankor is tétlen a rendőrség, amikor nem csupán a gyülekezési törvény elöírásaiból fakadóan kellett volna intézkedni büncselekmény gyanúja miatt, hanem a rendőrségi törvény alapján, konkrét elkövetővel szemben. Az esetek azt mutatják, hogy az

${ }^{534}$ Bócz Endre: Négy évtized az ügyészségen. Pályám emlékezete. Budapest: Pallas, 2010.

${ }^{535}$ Lásd uo. 378-383. 
elmulasztott intézkedések miatt sokszor nem sikerült az elkövető(ket) azonosítani (így a büntetőeljárást fel kellett függeszteni) vagy egyébként bizonyítékot nem sikerült beszerezni. Ezek a mulasztások pedig a büntetőeljárások eredményességét veszélyeztették. ${ }^{536}$

A nyomozati lépések elmulasztása körében szintén több problémára világít rá a kiadvány. Ezek föként a motivációt alátámasztó bizonyítékok beszerzéséhez kapcsolódónak (tanúkihallgatás elmulasztása, térfigyelő kamerák felvételeinek be nem szerzése, környezettanulmány el nem végzése). Mindezen mulasztások pedig azt eredményezik, hogy sem az ügyészség, sem a bíróság nem rendelkezik információval, bizonyítékkal, amelyek alapján az elöítélet-motívumnak megfelelő minősítés megtörténhetne. ${ }^{537}$

A téves minősítéssel szembeni jogorvoslattal kapcsolatban szintén rendszerszintü problémával találkoztak a GYEM tagszervezetei munkájuk során. ${ }^{538}$ Úgy tűnik, hogy a téves minősítésekkel kapcsolatos panaszok vonatkozásában közel sem egységes a joggyakorlat. Egyes esetekben a panaszokat elbírálták, míg más esetekben az ügyészség elutasította a panaszt azon az alapon, hogy a jogi minősítés nem tekinthető olyan, a sértett jogát vagy jogos érdekét közvetlenül érintő intézkedésnek, amelyet egyet nem értés esetén a sértett vagy jogi képviselője panasszal sérelmezhetne. A GYEM a kiadványban kifejti, hogy álláspontjuk szerint azonban a sértettnek nyilvánvalóan jogos érdeke füződik ahhoz, hogy az elkövetőt azért vonják felelősségre, amit elkövetett. Éppen ezért a probléma feloldása érdekében konkrét javaslatokkal is előálltak. Ha az ügyészség is egyetért a jogorvoslati jog meglétével, akkor körlevél kiadása lenne indokolt a joggyakorlat egységesítése érdekében. Végső esetben pedig jogszabály módosítást javasolnak, és erre az esetre konkrét szövegjavaslatot is megfogalmaznak.

A továbbiakban a fenti jogalkalmazási problémákra kíván rámutatni a dolgozat, felhasználva a GYEM egyes tagszervezetei (Háttér Társaság a Melegekért, TASZ) által mintegy 25 különböző ügyben rendelkezésre bocsátott, 2010-2012 közötti nyomozások során keletkezett iratokat. ${ }^{539} \mathrm{Az}$ ügyek számára tekintettel messzemenő következtetéseket levonni természetesen nem lehet, de bepillantást nyújthatnak a

\footnotetext{
536 Uo. 12.

${ }^{537}$ Uo. 14.

${ }^{538}$ Uo. 15.

${ }^{539}$ Az aktákat 2013 októberében adták át a szervezetek.
} 
tényállás alkalmazásának legalapvetőbb és ismétlődő problémáiba, hangsúlyozva a gyülölet-büncselekmények nyomozásánál jelentkező bizonyítási és minősítési nehézségeket, amelyek kétségkívül jelentős terhet hárítanak a nyomozati szervekre. $\mathrm{Az}$ alábbi ügyekben elsősorban a Btk. 216. § (1)-(2) bekezdésével és a hatásköri szabályok alkalmazásával kapcsolatban felmerülő problémákra igyekszik reflektálni a dolgozat, nem érintve a közösség tagja elleni erőszak minősített eseteit valamint a büntetni rendelt előkészületet. Tekintettel arra, hogy a - GYEM által is kiemelt - négy fö jogalkalmazási anomália egyes esetekben halmozottan jelenik meg, ezért a dolgozat elsősorban nem ezen problémák szempontjából csoportosítva vizsgálja az ügyeket, hanem a jogszabályhelyekhez kötődően a Btk. 216. § (1) és (2) bekezdése, valamint a hatásköri szabályok alapján.

\subsubsection{Btk. 216. § (1) bekezdéssel kapcsolatos jogalkalmazási problémák}

Az egyik megszüntetéssel végződő eljárásban a sértettek tábort szerveztek, amelyet egy közösségi portálon hirdették meg. A tábort egy magántulajdonban lévő ingatlan területén rendezték meg, mintegy 30-35 fő részvételével. A radikális deres.tv elnevezésű oldalra felkerült egy a táborról szóló hír, mint köztudottan meleg rendezvényről. Pénteki napon három személy - egyikőjük „betyárruházatban” ${ }^{540}$ fotózni kezdte a tábor résztvevőit. A sértettek kimentek megkérdezni, hogy mi a probléma, ekkor több sértő megjegyzés hangzott el a három személy részéről. A nap folyamán a körzeti megbízott tájékoztatta a tábor résztvevőit, hogy a Jobbik aznap négy órára sajtótájékoztatót hirdetett meg a ház elé. Meg is jelent 14-15 szimpatizáns Jobbik Komárom zászlóval, kamerával és fényképezőgépekkel. Ekkor a táborozók is fényképezni kezdték a megjelent csoportot. A sajtótájékoztató résztvevői részéről több sértő, szexuális orientációra utaló kifejezés hangzott el (, , a feleségem is úgy engedett el hozzátok köcsögök, hogy erényövet tett fel reggel”, „köcsögök”, „,hülye buzik” stb.). Körülbelül 45 perc után távoztak, majd miután a rendörség is elhagyta a helyszínt, megjelent egy fehér furgon, és a furgonból kiszálló férfi hangosbeszélővel a következő „verset” harsogta: „Tízet ütött már az óra, térjetek hát nyugovóra, tüzre-vízre vigyázzatok, le ne égjen a házatok!" A sértettek fenyegetve érezték magukat, ezért is mentek el feljelentést tenni. A fenti események (főleg a „vers” hangosbeszélőn történő elmondása) hatására többen elhagyták a tábor helyszínét és inkább hazamentek.

\footnotetext{
${ }^{540}$ Idézet a feljelentésből.
} 
A rendőrség a feljelentést elutasította, mivel álláspontja szerint a cselekmény nem büncselekmény. A határozat indokolása szerint legfeljebb a Btk. 222. § (2) bekezdés a) pontjának (zaklatás tényállásának) gyanúja merülhetne fel, azonban a fenti cselekmény során az ismeretlen személy (akit az ingatlan tulajdonosa felismert) által tett kijelentés nem értékelhető úgy, hogy az alkalmas legyen a sértettben komoly félelem keltésére, így a fenyegetés fogalmát nem meríti ki. A jogi képviselő panaszt nyújtott be, amelyben kifejtette, hogy álláspontjuk szerint az elkövetett cselekmények más büncselekményt, a Btk. 216. § (1) bekezdésében szabályozott közösség tagja elleni erőszak büntettét valósították meg. A panaszt az ügyészség elutasította. A határozat indokolása érdemben mindösszesen annyit tartalmaz, hogy kihívóan közösségellenesnek a közösségi, társadalmi együttélési szabályokkal nyíltan szembehelyezkedő antiszociális, provokatív jellegü magatartások tekinthetők, az elkövető a társadalmi együttélési szabályokat tudatosan figyelmen kívül hagyja, cselekménye az együttélési szabályokat jelentősen sérti. Az ezt el nem érő kisebb rendzavarások nem tekinthetők ilyennek. A panaszban foglaltak alapján a feljelentő sértett a feljelentés megtételekor szóban jelezte az eljáró rendőrnek, hogy a cselekmény álláspontja szerint megvalósította a Btk. 216. § (1) bekezdésében foglalt büncselekményt, és kérte emiatt a nyomozás lefolytatását. A külön kérés és a jogszabályi elő́rások ellenére azonban a kihallgatást vezető rendőr megtagadta ennek jegyzőkönyvezését.

A sértetti képviselő álláspontja szerint kétség kívül megállapítható, hogy a cselekmény a közösségi együttélés szabályait nyíltan, gátlástalanul, leplezetlenül semmibe vette, hiszen az elkövetők cselekményének egyértelmü célja az volt, hogy a sértettet és a táborban tartózkodó más személyeket is - szexuális irányultságuk miatt megfélemlítsék és megalázzák. Ez a cél semmiképpen nem egyeztethető össze a társadalom különböző csoportjai békés egymás mellett élésének elvével. Ilyen cselekménynek értékelhető különösképpen az, hogy az egyik szimpatizáns hangosbeszélővel az idézett fenyegető közlést intézte a táborban tartózkodókhoz. A sértett elmondása szerint a táborban tartózkodók ezeket a szavakat fenyegetésként fogták fel, többen ezen incidens miatt - biztonságukat féltve - haza is utaztak a táborból.

Az ügyben talán kissé elnagyolt az elutasító határozat indokolása, miszerint lényegében azért nem valósult meg a Btk. 216. § (1) bekezdésében foglalt büncselekmény, mert a 
cselekmények csupán kisebb rendzavarásnak minősülnek, és mint ilyenek, nem tekinthetők kihívóan közösségellenesnek. A kisebb rendzavarás és a kihívóan közösségellenesség között meghúzódó határ tekintetében kizárólag a bírói gyakorlat nyújthat eligazítást. Így például a bíróság kihívóan közösségellenesnek ítélte, amikor egy terhelt a társaival együtt a lánykollégiumba belopódzott, ott különböző helyeken szaladgált, a diáklányokat ijesztgette, zaklatta. ${ }^{541}$ Szintén kihívóan közösségellenesnek ítélte a bíróság egy másik terhelt cselekményét, amikor a sértett és az ittas terhelt között kialakult vitát és a bántalmazást követően odaérkező asszonyt a terhelt kikergette a lakásból, majd az udvaron tartózkodó két személyt szidalmazta. ${ }^{542}$ A garázdaság megállapíthatósága szempontjából egy cselekmény akkor közösségellenes, ha jellegére és körülményeire tekintettel az együttélési szabályokat jelentősen sérti. ${ }^{543}$ Egy másik esetben az irányadó tényállás szerint a vádlott egy délután, földszinti lakása ajtajában gyufával meggyújtott egy petárdát és azt a körfolyosós ház belső udvarába dobta. A petárda felrobbant és a robbanást több lakó is észlelte. Az első fokú ítélet megállapította, hogy a vádlotti magatartás a társadalmi együttélési normákat semmibe vevő, kihívóan közösségellenes volt (és ezt a másodfok is fenntartotta). ${ }^{544}$

A garázda jellegü cselekmények esetén egyébiránt nem a cselekményt észlelők szubjektív értékítélete alapján kell megítélni, hogy történt-e büncselekmény, hanem azt kell vizsgálni, hogy a cselekmény objektíve alkalmas-e arra, hogy megbotránkoztatást, riadalmat keltsen. Jelen esetben a fenyegető szóhasználat, a hangosbeszélővel kihangosított közlés alkalmas volt arra, hogy konkrétan a sértettben és általában a szemlélőkben riadalmat keltsen. E körben szükséges rámutatni, hogy szemben a Btk. 339. §-ában ${ }^{545}$ foglalt garázdaság tényállával, a Btk. 216. § (1) bekezdés szerinti garázda jellegű közösség tagja elleni erőszak tényállásának a magatartás erőszakos volta nem szükséges eleme.

A riadalom szó tekintetében egyébként a Magyar Értelmező Kéziszótár az alábbiakat tartalmazza: „tömegben hirtelen rémületböl eredö zürzavar”, „rég irod. hangos kiáltozás”. ${ }^{446}$ Rémület: „hirtelen támadt nagy félelem, ijedelem”547. Félelem: „valamely

\footnotetext{
${ }^{541} \mathrm{BH} 1980.116$.

$542 \mathrm{BH} 1981.489$.

543 BH 1990. 326.

${ }^{544} \mathrm{BH}$ 1994. 646.

545 1978. évi Btk. 271. §

${ }^{546}$ Magyar Értelmezö Kéziszótár, Akadémia Kiadó, Budapest, 1992. 1170.
} 
közelgö veszély okozta szorongó érzés" ${ }^{548}$ Ennek fényében a riadalom lényegében érzelmi megnyilvánulás, ami tartalmában az ijedtséget, illetőleg a félelmet jelenti. Megbotránkozás pedig az erkölcsi felháborodás érzése valami iránt. ${ }^{549}$ Konkrét esetre levetítve a homofób szitkozódás és egy magántulajdonban lévő községi ingatlan kapuja előtti hangoskodás alkalmas lehet a riadalomkeltésre, megbotránkozás okozására.

E kérdéskör kapcsán említést érdemel a „vers” történeti gyökere is, tekintettel a sorok eredeti, jelen helyzettel vélhetően teljesen ellentétes céljára. A polgári vagyonvédelmi feladatokat elsősorban az éjjeliőrök végezték a XVIII. században. Feladataik közé tartozott a tolvajlás megakadályozása, lakosság hangos szóval történő figyelmeztetése saját vagyonuk védelmére és az idő jelzésére való figyelemfelhívás az említett verssorokkal ("tízet ütött már az óra térjetek hát nyugovóra, tüzre, vízre vigyázzatok, le ne égjen a házatok!" ${ }^{550}$. Kiemelendő hogy a Btk. 216. § (1) bekezdésében foglalt büncselekményi tényállás azt követően került elfogadásra és beiktatásra az 1978. évi Btk.-ba, hogy a Szebb Jövőért Polgárőr Egyesület tagjai és a hozzájuk csatlakozó, egyenruhájuk alapján más szervezetekhez (pl. Véderő, Betyársereg) tartozó személyek 2011 márciusától különböző településeken kivitelezett járőr- és egyéb akciókkal az állam erőszak monopóliumát kérdőjelezték meg és a bünmegelőzés és rendfenntartás szerepében (polgárőrként) tetszelegtek.

A fentiekre figyelemmel a „vers” szövegét (és ebben a helyzetben való felhasználást) álláspontom szerint nem lehet függetleníteni az adott társadalmi kontextustól. Az elsőfokú bíróság Toroczkai László ügyében ${ }^{551}$ kifejtett véleménye is ezt támaszthatja alá, amelyben a vádlottat bünösnek mondta ki az 1978. évi Btk. 174/C. § (1) bekezdésében meghatározott és a (2) bekezdés ${ }^{552}$ szerint minősülő gyülekezési szabadság megsértése előkészületének vétségében. A bíróság az ügy tárgyát képező írás kapcsán kifejtette, hogy nem kizárólag a megfogalmazások nyelvtani értelme alapján hozta meg marasztaló határozatát, hanem az ismert társadalmi kontextus, a korábbi

\footnotetext{
${ }^{547}$ Uo. 1157.

548 Uo. 374.

549 Uo. 901.

550 B.-A.-Z. Megyei Bűnmegelőzési Alapítvány, Bűnmegelőzési Szolgálat, Rendészeti hírlevél melléklete, Bünmegelőzési ismeretek, 51. oldal http://www.bunmegelozes.eu/pdf/rendfebrmell.pdf (2013. szeptember 26.)

551 Toroczkai Lászlónak a kuruncinfo.hu internetes oldalon a Meleg Méltóság Menetet megelőzően írást tette közzé „Ismét szükség lesz a puskaporra” címmel, amely felhívást tartalmazott arra nézve, hogy akadályozzák a menet résztvevőit gyülekezési joguk gyakorlásában.

552 Btk. 217. § A hatályos Btk.-ból kikerült az akadályozás esetében a jogtalan jelzőt, illetve megszüntették az előkészület büntetését, amely jelen ügyben az elítélés alapját képezte.
} 
események, az azokra történő visszautalások és a megfogalmazás módja együttesen eredményezték azt, hogy a szövegnek más értelmet, mint erőszakos fellépésre történő buzdítást, nem lehetett tulajdonítani. Mindezek fényében a jelen ügyben az ismert társadalmi kontextus, a megjelent cikkek, ${ }^{553}$ a Jobbik homoszexualitásról vallott nézetei, ${ }^{554}$ a helyszínen elhangzott szitkozódások azt valószínüsítik, hogy a „vers” nem a sértettek figyelmét kívánta felhívni hangos szóval saját vagyonuk védelmére és nem az időt kívánták jelezni, hanem burkoltan igyekeztek bennük félelmet kelteni.

Visszautalva a bíróság korábban említett döntésére, miszerint a kihívóan közösségellenesség azt jelenti, hogy az elkövető a közösségi együttélés szabályait nyíltan, gátlástalanul, leplezetlenül semmibe veszi, feltünést kelt öntörvényü, jogsértő viselkedésével, ${ }^{555}$ érdemes lett volna az előre bejelentett sajtótájékoztató jogszerüségét is vizsgálat alá venni a közösségellenesség alátámasztásának egy lehetséges módjaként. A feltünést keltő, öntörvényü viselkedés, álláspontom szerint a fentiek alapján kétségtelen. Azonban jogsértőnek is bizonyulhat a magatartás, amennyiben bebizonyosodik, hogy a sajtótájékoztató nem felelt meg a jogszabályi előírásoknak. Jelen írásnak nem célja gyülekezési jogot érintő kérdésekkel mélyrehatóan foglalkozni, mindazonáltal fontos felhívni a figyelmet a „captive audience” (foglyul ejtett közönség) fogalmára, amely alapján senki nem kényszeríthető egy vélemény végighallgatására, különösen nem az őt gyalázó, megfélemlítő üzenetekhez való asszisztálásra, és mint ilyenre nem terjed ki sem a szólás szabadságához, sem a békés gyülekezéshez való jog. 556

Mindezek fényében nem eleve elvetélt a jogi képviselö azon érvelése, hogy a „vers”, az egyértelműen szélsőséges csoporthoz tartozó egyének jelenléte, valamint a „vers” mellett elhangzott homofób kijelentések együttesen

553 például: Komárom mellett pihenik ki az „olimpia” és a parádé „fáradalmait” a buzik, http://kuruc.info/r/2/99237/ (2013. szeptember 26.)

554 Börtönbe zárná a Jobbik a melegeket, http://hvg.hu/itthon/20120411_jobbik_tervezet (2013. szeptember 26.)

555 BH 2009. 171.

556 A magyar jogban e tétel elöször az 55/2001. (XI. 29.) AB határozathoz fözött különvéleményben merült fel. Eszerint foglyul ejtett közönség akkor jön létre, ha „a résztvevők oly módon nyilvánítanak véleményt más magánszemélyekkel szemben, hogy azok ne tudják elkerülni a rendezvényen elhangzó, őket hátrányosan érintő kijelentések végighallgatását”. A tétel megjelent az Emberi Jogok Európai Bíróságának Magyar Gárdáról szóló ítéletében is. ECtHr, Case of Vona v. Hungary, No. 35943/10, 9 July 2013. http://hudoc.echr.coe.int/sites/eng/pages/search.aspx?i=001-122183\#\{"itemid":["001-122183"]\} (2013. november 26.) 
eredményezhettek/eredményeztek ${ }^{557}$ riadalmat a sértettek körében, illetve megbotránkozást válthattak volna ki (váltottak ki) a különböző homofób kijelentések, élcelődések, felkiáltások. Mégis, tekintettel arra, hogy nyomozás nem indult, így adatok sem állnak rendelkezésre, hogy a sajtótájékoztatón résztvevők és a furgonnal érkezők azonosak-e. Azonban a nyomozás folytatását, további bizonyítékok feltárását és értékelését követően alaposan feltehető, hogy a közösség tagja elleni erőszak alapos gyanúja beigazolódik.

Külön említést érdemel újfent, hogy a 2011-es gyöngyöspatai események hatására került az 1978. évi Btk.-ba a garázda jellegü magatartással megvalósított közösség tagja elleni erőszak tényállása. Számos olyan eset történt ez idő alatt a településen, amelyre alkalmazható lett volna a rendelkezés, ha az elkövetés idején hatályban lett volna. Így például különösen érdekes minősítési szempontból az alábbi eset.

2011 áprilisában a két sértett hazament vacsorázni, gyerekeiket egy másik házban hagyták, mivel ekkor voltak jelen a településen paramilitáris szervezetek tagjai, akik magukat polgárőrnek kiadva a helyi roma lakosságot megfélemlítették és ennek következtében a család sem érezte magát biztonságban. Elmondásuk szerint féltek a cigánysoron tartózkodni, csupán ételért mentek haza. A kapu előtt öt feketeruhás személy szitkozódott. Ketten a kapu elé mentek és kővel bedobták az ablakot, miközben az alábbi mondatot kiabálták többek között: „Meghaltok, büdös, tetves cigányok, ha nem költöztök el innen Patáról!’. Az ügyben eljárás indult a Btk. 339. § (1) bekezdés első fordulata szerint minősülő garázdaság vétsége miatt. Majd a nyomozást felfüggesztették, mivel az elkövető kiléte nem volt megállapítható. Az eset iskolapéldául is szolgálhatna a Btk. 216. § (1) bekezdéshez, tekintve, hogy a kihívóan közösségellenesség és a riadalom keltésére való alkalmasság konjunktív feltétele fennállt. Mindezt az ítélkezési gyakorlat is alátámasztja. A bíróság egy döntésében foglaltak szerint a terhelt éjjel 1 óra tájban ittasan indult haza. Útközben bemászott a sértett udvarába a kerítésen keresztül, majd egy kővel beverte a ház egyik ablakát és az ablakban lévő virágcserepek közül hármat az utcára dobott. A zajra a szomszédok is felébredtek, és felszólításukra a terhelt elhagyta a helyszínt. A terheltnek a magatartása alkalmas volt arra, hogy másokban megbotránkozást vagy riadalmat keltsen, és ez - a kihívóan közösségellenes viselkedés eredményeként - be is következett. A zaj a

557 A kihívóan közösségellenes magatartásnak alkalmasnak kell lennie arra, hogy riadalmat keltsen, azonban a büncselekmény megvalósulásához nincs szükség arra, hogy a riadalom be is következzen. 
szomszédok nyugalmát megzavarta. ${ }^{558}$ Ennek fényében a fenti ügyben részletezett magatartás alkalmas lehetett volna a Btk. 216. § (1) bekezdésbe ütköző kihívóan közösségellenes magatartással elkövetett közösség tagja elleni erőszak bűntettének megállapítására. Azonban a törvényhely kizárólag a 2011. május 7. napját követően elkövetett cselekményekre alkalmazható, jelen ügyben pedig az elkövetés időpontja 2011. április 16. napja volt, amikor a bekezdés még nem lépett hatályba. Mindazonáltal a rendelkezésre álló adatok alapján felmerülhet a Btk. 216. § (2) bekezdésének gyanúja is. Fontos részlet az ügyben, hogy a kődobálások közben különböző fenyegetések hangzottak el, így többek között a fent említett mondat is, amelyben a sértetteket költözésre kényszerítik az elkövetők. A dolog elleni erőszakkal elkövetett közösség tagja elleni erőszak ugyanis a Btk. 216. § (2) bekezdés szerint minősül [és nem a Btk. 216. § (1) bekezdés szerint], ha az fenyegetéssel kényszerítést valósít meg. Márpedig jelen esetben az elkövetők szándéka arra terjedhetett ki, hogy a sértetteket költözésre kényszerítsék. E megközelítés tekintetében nem elhanyagolható, hogy a településen ezidőtájt számos paramilitáris csoport tartózkodott, amelyek jelenléte és tevékenysége a község roma lakosaiban félelmet keltett és amely csoportoknak - a sértettek elmondása szerint - az elkövetők azonosíthatóan tagjai voltak. A kényszerítés megkezdésével pedig (fenyegetés) már tényállási elem valósul meg, tehát a cselekmény kísérleti szakba lép. Így álláspontom szerint a helyes minősítésről való meggyőződés érdekében további vizsgálatok nagy valószínséggel alátámaszthatták volna a Btk. 216. § (2) bekezdés kísérletének gyanúját. 559

A fentiek ellenére garázdaság miatt indult nyomozás, de elmulasztották beszerezni azokat a bizonyítási eszközöket, amelyek az elkövetők beazonosítását szolgálták volna, ezt a hibát utóbb a megyei rendőrkapitányság is elismerte. Néhány nappal később az egyik sértett felismerte az elkövetőket az utcán, ám a helyszínen lévő rendőr nem intézkedett velük szemben. A garázdaságként való minősítéssel, majd a nyomozás felfüggesztésével szemben a sértett nem élt panasszal, mert nem látta már értelmét, nem tudott már bízni a hatóságban. ${ }^{560}$

Komplexitásából eredően csupán részben tartozik a 216. § (1) bekezdéséhez az ún. „devecseri eset”, amely több szempontból is szemlélteti a jogalkalmazás során

${ }_{558}$ BH 1985. 291.

${ }^{559}$ Hasonló esetre lásd a bántalmazással és kényszerítéssel elkövetett közösség tagja elleni erőszak terén ismerttett ügyekkel kapcsolatban leírtakat.

560 GYEM: Jogalkalmazási problémák a gyülölet-büncselekményekkel... 2014, 5. és 11. 
megjelenő problémákat, illetve illusztratív példája az erőszak eszkalálódásának. Az eset a romák elleni rasszista incidensek és büncselekmények körében egy viszonylag új jelenség része volt. Egy olyan jelenségé, amely több helyen erőszakos cselekményekhez, illetve végső soron jogszabály-módosításhoz is vezetett. A tényállás 2011-es kiegészítésére egy nagy visszhangot kiváltó incidens-sorozat, a gyöngyöspatai roma közösség tagjai elleni szélsőséges, megfélemlítő fellépésre szánták válaszul. Azonban Gyöngyöspata után még számos településről lehetett hallani, ahol szélsőséges csoportok vonultak fel, megfélemlítve a helyi cigány lakosságot. ${ }^{561}$ Többek között ilyen jellegü, megfélemlítő tevékenység miatt oszlatta fel a Szegedi Ítélőtábla 2014. október 8-án a Szebb Jövőért Egyesületet. ${ }^{562}$

2012 augusztusában a Jobbik demonstrációt szervezett Devecseren „Élni és élni hagyni, demonstráció a jogos magyar önvédelemért" címmel. ${ }^{563}$ A tüntetésen több szélsőséges szervezet vett részt, többen felfegyverkezve (vascsővel, kővel, ostorral, botokkal), sokan alakzatban, vezényszavakra vonultak. A demonstráció célját különböző internetes források a „magyarokat lincselő devecseri cigányok”, illetve „az együttélési normákat betartani képtelen cigánybünözők” elleni fellépésben jelölték meg. ${ }^{564}$ Számos uszító, az indulatok felkorbácsolására alkalmas kijelentés hangzott el a szónokoktól, így például Tyirityán Zsolt - a Betyársereg vezetője - a közönség előtt a faji háború jeleiről és etnikai alapú konfliktusról beszélt. Egyebek mellett azt mondta: a cigány fajta úgy van kódolva, hogy benne van a bünözés, ,a genetikailag kódolt hulladékokat ki kell irtani a közéletböl”, majd kijelentette, hogy ,eltapossuk azt a jelenséget, amit ki kell irtani az életterünkből". Habár a tüntetés hamar elveszítette békés jellegét, a rendörök nem oszlatták fel a tömeget, nem igazoltatták a rendbontókat, nem indítottak ellenük eljárást. ${ }^{565} \mathrm{~A}$ beszédeket követően a demonstrálók a település romák lakta részére vonultak, ahol rasszista, kirekesztő jelszavakat (pl. „mocskos cigányok!”) skandáltak, majd vizes palackokkal, betondarabokkal, kövekkel kezdték dobálni a romák által lakott

561 Például Kunhegyes, Devecser, Debrecen. Lásd Index: Jogerös: feloszlatták a Szebb Jövöért Egyesületet. 2014. http://index.hu/belfold/2014/10/08/jogeros_feloszlatjak_a_szebb_jovoert_egyesuletet/ (2015. július 19.)

${ }^{562}$ Lásd uo.

563 Lásd pl. HVG: Toroczkaival vonul a Jobbik a halálbüntetés mellett. 2012. http://hvg.hu/itthon.parlament/20120805_Jobbik_Devecser (2015. július 27.)

564 Lásd pl. ATV: Ezres tömeg vonult Devecserben a „cigánybünözés” ellen. 2012. http://www.atv.hu/belfold/20120805_devecser (2015. július 27.)

565 Helsinki Bizottság: Etnikai mocskolódás és megkövezés „,békés jelleggel”. 2012. http://helsinki.hu/etnikai-mocskolodas-es-megkovezes-\%E2\%80\%9Ebekes-jelleggel\%E2\%80\%9D (2015. július 28.) 
házakat. Az egyik ház udvarára bedobott betondaraboktól és kövektöl többen megsérültek. ${ }^{566}$

A civil szervezetek képviselőiből, illetve szakértőkből álló Gyülölet-büncselekmények Elleni Munkacsoport (GYEM) már a kezdetektől amellett foglalt állást, hogy a romák lakta utcákban való „mocskos cigányozással” megvalósították - csoportosan - a közösség tagja elleni erőszak garázda alakzatát [Régi Btk. 174/B. § (1a)], a palackok, kövek, betondarabok dobálásával pedig erőszakos gyülölet-büncselekményt bántalmazás kísérletét, illetőleg azok tekintetében, akiket eltaláltak, befejezett bántalmazást - [Régi Btk. 174/B. § (1)] követtek el. A nyomozóhatóság csak nyolc hónappal később, 2013 áprilisában minősítette közösség tagja elleni erőszakként a kapcsolódó ügyeket, hét esetben. A rendőrség azonban elmulasztotta elemi fontosságú lépések- igazoltatások, előállítások, térfigyelő kamerák felvételeinek beszerzése megtételét; ennek következtében pedig nem tudták azonosítani az elkövetőek. Az elmulasztott rendőri intézkedések miatt mindössze egy elkövetőt sikerült beazonosítani, így vádemelésre is csak egy személlyel szemben került sor. A többi esetben felfüggesztették az ismeretlen elkövető ellen indított büntetőeljárást. Az igazoltatások és az oszlatás elmaradása miatti panaszeljárások azóta is folyamatban vannak, várhatóan 2015-ben a Kúria elött folytatódik az eljárás. ${ }^{567} \mathrm{Az}$ ügy jól szemlélteti a gyülöletbüncselekmények jellemzőit: egy demonstráció hogyan csap át gyülöletkeltő beszédek sorozatába, majd dolog és személy elleni erőszakba, amely végső soron csoportok közötti összecsapásokhoz is vezethetett volna, ha a rendörség egy kicsit is kélekedik a beavatkozással.

A fent részletezett ügy kapcsán a közösség elleni uszítás és a közösség tagja elleni erőszak megvalósulásának és az elhatárolásának kérdése is felmerül. Amint a tényállásból látszik, a beszédeket követően a demonstrálók a település romák által lakott részére vonultak, ahol már erőszakos cselekményekre is sor került. A demonstráció időpontjában hatályos Büntető Törvénykönyv szerint, „aki nagy nyilvánosság elött valamely etnikai, faji, vallási csoport vagy a lakosság egyes csoportjai ellen gyülöletre uszit, büntett miatt három évig terjedő szabadságvesztéssel büntetendö." ${ }^{568}$ A közösség elleni izgatás büntetőjogi tényállásában szereplő „gyülöletre uszításra” nézve irányadó

\footnotetext{
${ }^{566}$ GYEM: Jogalkalmazási problémák... 2014, 6.

567 Lásd uo. 10.

${ }^{568}$ Régi Btk. 269. § Közösség elleni izgatás
} 
alkotmányos mérce mibenléte a magyar joggyakorlat és a szólásszabadság-jogi irodalom egyik nagy és lezáratlan kérdése. ${ }^{569}$ A magyar bírói gyakorlat e rendelkezést meglehetősen szűkítően értelmezi, és csak akkor találja megállapíthatónak a büncselekményt, ha a gyülöletkeltés nyomán felmerül az erőszak egyértelmü és közvetlen veszélye. Jelen esetben nem csupán az erőszak egyértelmü és közvetlen veszélye állt fent, hanem ténylegesen sor került az erőszakra. Éppen ezért a Magyar Helsinki Bizottság közösség elleni izgatás miatt tett feljelentést az uszító beszédeket tartó személyek ellen.

Ebben körben ismételten érdemes rámutatni, hogy a közösség tagja elleni erőszak és a közösség elleni izgatás kapcsolatát illetően problémás lehet az elhatárolás. Az uszítás mint elkövetési magatartás 2004 óta létező extrém módon szűk értelmezése miatt az erőszakra irányuló előkészülettől szinte alig elhatárolható.

A tényállásokkal kapcsolatos zavaros helyzet fényében még azt is állíthatnánk, hogy nem meglepő a Veszprém Megyei Rendőr-főkapitányság határozata, ${ }^{570}$ amely a nyomozást büncselekmény hiányában megszüntette. A határozat szerint ,[a]ki uszít, az nem az értelemhez szól, hanem a primér ösztönöket célozza meg, [...] számolva azzal, hogy a felszított ellenséges indulatok kitörhetnek, és fékezhetetlenné válhatnak". A főkapitányság szerint azonban az elhangzott felszólalások , ,ilyen jellegü nem átgondolt, indulatból, ösztönböl fakadó, ellenséges, ártó megnyilvánulás kiváltására alkalmas kijelentést nem tartalmaztak. A beszédekben elhangzottak egy része sértö lehet a cigányságra nézve, amely erkölcsileg ugyan kifogásolható, de a büntetöjog eszközeivel nem szankcionálható." Tehát a rendőrség abból indult ki, hogy a büncselekmény akkor valósul meg, ha az elkövető magatartása magában hordozza ,a gyülölet önfejlődésével az erőszakos jellegü konkrét sérelem reális lehetőségét"; azaz a rendőrség szerint önmagában a gyülöletkeltés nem, hanem a sérelem annak következtében kialakuló valós veszélye szükséges a büncselekmény megvalósulásához. ${ }^{571}$

Ezzel szemben a Helsinki Bizottság határozottan akképp foglalt állást, hogy megvalósult a közösség elleni izgatás tényállása és nem merő véletlen, hogy éppen e

\footnotetext{
${ }^{569}$ Koltay András: „A nagy magyar gyülöletbeszéd-vita: a »gyülöletre uszítás« alkotmányos mércéjének azonosítása felé”Állam- és Jogtudomány, 2013/1-2. 91-123.

570 Veszprém Megyei Rendör-fökapitányság, Bünügyi Igazgatóság, Vizsgálati Osztály, 19000/156/2012.bü. sz. határozat. http://helsinki.hu/wp-content/uploads/Devecser_hatarozat_201309.pdf (2015. július 29.)

${ }^{571}$ Koltay András (szerk.): A gyülöletbeszéd korlátozása Magyarországon. Budapest: CompLex, 2013. 70.
} 
beszédek után indult meg a tömeg a romák házai felé, és tanúsított sérülést is okozó, erőszakos magatartást. Koltay András álláspontja szerint azonban az lett volna a legszerencsésebb, ha az ügyben bíróság hozhatott volna döntést, mert a rendörségi határozatok nem alkalmasak arra, hogy a felmerülő - ennyire komplex és széles körben vitatott - kérdésekben kellő mélységü elemzést adjanak. ${ }^{572}$ Koltay ezzel az állásfoglalással egyúttal a büncselekmény gyanúját, illetve a későbbi vádemelés lehetőségét sem tartotta kizártnak.

\subsubsection{Btk. 216. § (2) bekezdéssel kapcsolatos jogalkalmazási problémák}

Az alábbi eset a Btk. 216. § (2) bekezdés bántalmazásos alakzatát szemlélteti. A sértett 2011 júniusában a Meleg Méltóság Menetén vett részt barátjával. Az esemény végeztével a Nyugati tér felé távoztak, ahol lementek a metróállomásra, hogy elhagyják a helyszínt. A metróállomáson két atlétatrikós, középkorú, ismeretlen férfi odament hozzájuk és provokálni kezdték őket, rákérdeztek, hogy részt vettek-e a rendezvényen, és ha igen „melyik oldalon”, közben folyamatosan homofób megjegyzésekkel sértegették őket. Majd megpróbálták megakadályozni a sértetteket, hogy felszálljanak az érkező metrószerelvényre, és tovább sértegették őket. A sértettek határozottan felszólították őket, hogy fejezzék be a provokációt, ekkor megérkezett a M3-as metró, Köbánya-Kispest irányába, megvárták, míg az elkövetők felszállnak, és szándékosan egy másik metró kocsiba szálltak be. A következő megállónál (Arany János utca), az elkövetők átmentek a sértettek metró kocsijába és további homofób kijelentések kísértében fenyegetően eléjük álltak. A Deák térhez érve a sértettek kijelentették, hogy ha nem hagyják békén őket, hívják a biztonságiakat. Megpróbáltak leszállni, amit először nem engedtek, de végül sikerült lelépniük a jármüről. Leszállás közben az egyikük leköpte és belerúgott a sértett lábába, még éppen azelőtt, hogy bezáródott volna az ajtó. A metrószerelvénnyel aztán az elkövetők továbbutaztak, a sértettek ottmaradtak a Deák téri metróállomáson.

A nyomozást Btk. 216. § (2) bekezdésének alapos gyanúja alapján a BRFK Szervezett Bűnözés Elleni Főosztály, Szervezett Bünözés Elleni Osztálya végezte. Az eljárást a Be. 188. $\S(1)$ bekezdés c) pontja alapján - figyelemmel 189. § (1) bekezdés első mondatára - mivel az elkövető kiléte a nyomozásban nem volt megállapítható, felfüggesztette.

572 Lásd uo. 71. 
Amint azt a sértetti képviselő is kifejtette, az ilyen fajta erőszakos fellépés mindenképpen kimeríti a bántalmazás fogalmát, tekintettel arra, hogy a Btk. 164. §-ával szemben a közösség tagja elleni erőszak tényállása nem követeli meg a testi épség vagy egészség sérelmét, a bántalmazás ténye önmagában is megvalósítja a büncselekményt. Arra vonatkozóan, hogy az incidensre vélt szexuális irányultságuk miatt került sor, már az eljárás korai szakaszában felmerült a gyanú. Az elkövetők többször is tettek szexuális irányultságukra való utalást. Az esetre közvetlenül a Meleg Méltóság Menet után, annak záró helyszínétöl nem messze került sor, azaz a büncselekmény egybeesett az érintett csoport kiemelt fontosságú eseményével. Ezen körülmények mind a homofób motivációt erősítik, így hasonló esetekben is további vizsgálatok elvégzését teszik szükségessé, tekintettel a homofób motiváció gyanújára.

A következö eset a Btk. 216. § (2) bekezdés II. fordulatára (eröszakkal vagy fenyegetéssel kényszerítés) szolgál példaként. ${ }^{573} 2007$ novemberében vásároltak házat a sértettek az elkövető szomszédságában. Az elkövető a sértetteket cigány származása, illetve vélt cigány származása miatt 2007 novemberétől 2010 áprilisáig több alkalommal, rendszeresen sértegette, fenyegette, az ingatlanukra a kutyáit beterelte, az autójával a telken közlekedett, közvetlenül az ablak alatt állva nappali és éjszakai időpontban is perceken keresztül dudált. Ezeken túlmenően a sértetteket velük találkozva, rendszeresen házuk felgyújtásával, ledózeroltatásával, elütésükkel, lelövésükkel fenyegette, több alkalommal fegyvernek látszó tárgyat fogott rájuk, közölte a sértettekkel, hogy neki „olyan puskája van, ami vaddisznóra, szarvasra, meg cigányra lö". Közölte a sértettekkel azt is, hogy ök „putris cigányok, nem türi meg, hogy cigányok lakjanak a közelében, és így vagy úgy el fogja öket tüntetni onnét". Egy alkalommal az állapotos sértett elütésével fenyegetőzött, mondván, hogy "ne szülessen újabb cigány poronty".

A bíróság tanúk sokaságát hallgatta meg a gyülölet motivációról való meggyőződés érdekében, így szomszédokat, a vádlott által elkövetett egyéb büncselekmények sértettjeit, cellatársait. Az igazságügyi elmeorvosi szakértő szakvéleményében is alátámasztotta cigánysággal szembeni szélsőséges nézeteit, illetve az elkövető tárgyalás során tett megnyilvánulásai (többször kellett figyelmeztetni és rendre utasítani, hogy tartózkodjon a rasszista jellegü kijelentésektől) is mind a rasszista motivációt igazolták.

573 Zalaegerszegi Járásbíróság B.404/2011/101, Zalaegerszegi Törvényszék Bf.152/2012/5, Pécsi Ítélőtábla Bhar.247/2012/18. 
A sértettek egymást erősítő egybehangzó vallomásai és a nagyszámú tanúvallomás alapján kétséget kizáróan megállapítható volt az ötrendbeli a Btk. 216. § (2) bekezdésébe ütköző közösség tagja elleni erőszak büntettének kísérlete. Másodfokon a bíróság rámutatott, hogy a városi bíróság helyesen állapította meg, hogy a vádlott ugyanolyan büncselekményt azonos sértettek sérelmére, rövid időközökben, többször követett el egységes elhatározással, azonban e cselekmény tekintetében a folytatólagos elkövetést elmulasztotta értékelni, így a másodfokú bíróság pótolta akként, hogy a Btk. 216. § (2) bekezdésébe ütköző és minősülő ötrendbeli közösség tagja elleni erőszak büntettének kísérlete körében a folytatólagos elkövetést megállapította.

A bíróság megállapította, hogy az elkövető azzal a szándékkal cselekedett, hogy a sértetteket rákényszerítse a település elhagyására. Magatartásával, valamint fenyegetéseivel a sértettekben félelmet keltett, valamint felháborodást, a sértettek végül azt is felajánlották, hogy vásárolja meg tőlük az általuk felújított ingatlant, és akkor ők elmennek.

Amint már korábban említettem, az elkövetési magatartás valaminek a megtételére, meg nem tételére vagy eltürésére történő kényszerítés. A kényszerítés megkezdésével azonban (fenyegetés) már tényállási elem valósul meg, tehát a cselekmény kísérleti szakba lépett, azonban tekintettel arra, hogy nem költöztek el, a büncselekmény nem befejezett, mivel az akaratukkal ellentétes tevékenység, amire az elkövető egyenes szándéka kiterjedt nem valósult meg ${ }^{574}$ (a tényállás fényében az elkövető egyenes szándéka arra terjedt ki, hogy a sértetteket elköltözésre kényszerítse, viszont ez, mint a sértettek akaratával ellentétes tevékenység nem történt meg).

\subsubsection{Hatáskörrel kapcsolatban felmerülö problémák}

2011 decemberében, Budapesten, egy a Margit körúton található sörözőben tettlegesen bántalmazták a sértettet rasszista kijelentések kíséretében, aki 8 napon túl gyógyuló sérüléseket szenvedett. A nyomozást a II. kerületi Rendőrkapitányság Bűnügyi Osztálya végezte a Btk. 216. § (2) bekezdésbe ütköző közösség tagja elleni erőszak büntette és a Btk. 164. § (2) bekezdésbe ütköző súlyos testi sértés bűntettének megalapozott gyanúja miatt. Az ügy csupán az eljárás felfüggesztéséről szóló határozat megpanaszolását

574 A Btk. 216. § (2) bekezdésben írt kényszerítéssel megvalósuló bủncselekmény befejezettségét hasonlóan határozza meg Hollán Miklós: „Az önrendelkezés elleni bűncselekmények” In: Hollán-Kis 2011,60 . 
követően került át az akkor hatáskörrel rendelkező BRFK Felderítő főosztály Vegyes Büncselekmények Osztálya, Vegyes Büncselekmények Alosztályához, ahol jelenleg is folyamatban van. Azóta számos nyomozati cselekményt elvégzett a BRFK, azonban sikertelenül, az elkövetőket nem sikerült beazonosítani. Az időmúlás, az eredetileg elmulasztott nyomozati cselekmények nagyban hozzájárultak az eljárás felfüggesztéséhez.

Az ügyben a hatásköri szabályok alkalmazásával kapcsolatos problémák mellett nyomozati cselekmények megtételét is elmulasztották. Tizenkét tanú meghallgatására vonatkozó indítványok közül egynek sem adtak helyt, illetve a felfüggesztő határozatot nem kézbesítették a sértettnek (és jogi képviselőjének sem).

Hasonlóképp nehézséget okozott a cselekmény minősítése és ennek következtében a hatásköri szabályok alkalmazása egy szintén 2012-es ügyben. A sértettek 2012 májusában az egyik fóvárosi bevásárlóközpont sörözőjében tartózkodtak. Az elkövető egy szék miatt kialakult vita kapcsán nyilvánosan szidalmazni, sértegetni kezdte mindkettőjüket cigány, illetve zsidó származásuk miatt. A sértettek a helyszínen feljelentést tettek. Becsületsértés vétsége miatt indult bírósági eljárás, amelynek során a sértettek előadták, hogy miért nem a Btk. 227. §-ban ${ }^{575}$ foglalt becsületsértés vétségének, hanem Btk. 216. § (1) bekezdésben foglalt közösség tagja elleni erőszak büntettének minősül a cselekmény. Jogi képviselő útján indítványozták, hogy a Be. 501. $\S$ (2) bekezdése alapján - a Be. 501.§ (1) bekezdés a) pontjában megjelölt okból ${ }^{576}$ határozzon a bíróság az ügy ügyészségre történő áttételéről. Álláspontjuk szerint a rendőrség alulminősítette a bűncselekményt; nem vette figyelembe, hogy a sértegetésre és szidalmazásra a sértettek etnikai, illetve vallási csoporthoz tartozása miatt került sor, tehát előítéletes, rasszista indítékból követte el a büncselekményt, amelynek elkövetési magatartása alkalmas a Btk. 216. (1) bekezdés megállapítására. A tárgyaláson az elkövető elismerte, hogy a zsidó és cigány szavakkal illette a sértetteket. Az indítvány ellenére 2012 szeptemberében az I. fokú bíróság az eljárás büncselekmény hiányában történt megszüntetése mellett az iratokat megküldte az I. fokú szabálysértési hatóságnak (becsületsértés szabálysértésére hivatkozva). A jogi képviselő fellebbezését a bíróság arra való hivatkozásával utasította el, hogy azt álláspontja szerint a jogi képviselő saját nevében nyújtotta be, márpedig a sértetti jogi képviselőt önálló fellebbezési jog nem

575 1978. évi Btk. 179. §

576 A bíróság az iratokat megküldi az ügyésznek, ha a feljelentés és az iratok alapján olyan büncselekmény látszik megállapíthatónak, amely miatt a vádat az ügyész képviseli. 
illeti meg. A bíróság alaptalanul utasította el a fellebbezést, hiszen azt a sértett képviseletében nyújtotta be a jogi képviselö, azonban a végzéssel szemben nem volt jogorvoslati lehetőség. Tekintettel arra, hogy a büntetöügyben született határozat (miszerint a bíróság az eljárást büncselekmény hiányában megszüntette) anyagi jogi jogerővel nem bír, így nem eredményez res iudicata-t, ennek megfelelően helye volt új feljelentés tételének. A jogi képviselő a Btk. 216.§ (1) bekezdés szerint minősülő közösség tagja elleni erőszak büntettének megalapozott gyanúja miatt újfent feljelentést tett, amelyet a nyomozó hatóság a Be. 174. § (1) bekezdés a) pontja alapján - mivel a cselekmény nem büncselekmény - elutasított, mert álláspontja szerint a cselekmény a Btk. 332. §-ában foglalt közösség elleni uszítás ${ }^{577}$ büntettét nem merítette ki. Minden bizonnyal elírás következtében a nyomozóhatóság tévesen hivatkozott a Btk. 332. §-ára, amelyre a jogi képviselö panaszában rá is mutatott. A panasznak helyt adva a rendőrség elrendelte a nyomozás folytatását a Btk. 216. § (1) bekezdésébe ütköző közösség tagja elleni erőszak büntettének gyanúja miatt és az ügyet áttették a hatáskörrel rendelkező hatósághoz (BRFK Korrupciós és Gazdasági Bünözés Elleni Főosztály). Az ügy kivételesen jól szemlélteti a motiváció felismerése kapcsán jelentkező problémákat, illetve, hogy mennyire elnyújthatja az eljárás időtartamát cselekmény félreminősítése. Holott a fent vázolt esetben számos jel utal közösség tagja elleni erőszak gyanújára, így például az áldozatok és szemtanúk véleménye a cselekményről, az elkövető kijelentései. ${ }^{578}$ Ezek természetesen első pillantásra még nem bizonyítják a gyülöletbűncselekmény megvalósulását, mindazonáltal további vizsgálatok szükségességét támasztják alá.

A 2012-es Meleg Méltóság Menete után a rendezvényt elhagyó testvérpárt fekete ruhás ellentüntetők a sértetteket szexuális irányultságára utaló kijelentések közben tettlegesen bántalmazták. A helyszínen a rendezvény biztosításért felelős Gazdaságvédelmi Főosztályhoz (Korrupciós Bünözés Elleni Osztályhoz) tartozó rendőrök intézkedtek, a feljelentést is ők vették fel. Már a helyszínen felmerült a Btk. 216. § gyanúja, a nyomozást is közösség tagja elleni erőszak miatt indították, a Gazdaságvédelemi Főosztály hatáskör hiánya miatt az ügyet áttette a BRFK Szervezett Bünözés Elleni Főosztályához, azonban az ügyben végül a nyomozást a XIX. kerületi 
Rendőrkapitányság folytatta, 2013 októberében pedig az ügyészség vádat emelt közösség tagja elleni erőszak miatt.

A fenti, valamint az említett kiadványban vázolt esetek és azokkal kapcsolatban felmerült jogalkalmazási anomáliák jól példázzák, hogy a gyülölet-büncselekmények nyomozása korántsem hétköznapi feladat. Ezen ügyek szemmel láthatóan csekély arányban jutnak el a vádemelésig - nem, hogy egy jogerős ítéletig, így egységes jogalkalmazási gyakorlat sem áll rendelkezésre, amely támpontot jelenthetne a rendőrség és az ügyészség számára. Erre tekintettel újfent csak hangsúlyozni tudom a képzések és az egység szakvonal keretében történő fellépés jelentőségét, amely hozzájárul ahhoz, hogy a rendőrség tagjai felismerjék a gyülöletvezérelte büncselekményeket, és tudatos, elsajátított elvek mentén végezzék a nyomozást.

\subsection{Magyarellenes inditék}

Külön említést érdemel a magyar jogalkalmazás által vett azon - álláspontom szerint téves, a kisebbséget védő intézményt a többség védelmében felhasználó - irány, amelyben roma embereket ítélnek el közösség tagja elleni erőszak büncselekményéért. ${ }^{579} 2013$ ősze óta több esetben is született ítélet „magyarellenes” közösség tagja elleni erőszak büncselekményéért. Ezen jogalkalmazási anomália jelentőségét tovább fokozza az, hogy a jelenleg elérhető ${ }^{580}$ közösség tagja elleni erőszak büncselekményében született bírósági határozatok közül három esetben ${ }^{581}$ magyarellenes indíték miatt vonták felelősségre az elkövetőket, ezzel szemben csak egy esetet találhatunk, ahol a büncselekményt valóban sérülékeny csoport tagjai (romák) ellen követték el. ${ }^{582}$ Emellett további egy romák ellen elkövetett közösség tagja elleni erőszakról van tudomásom, ${ }^{583}$ illetve még egy ,magyarellenes” közösség tagja elleni

\footnotetext{
579 A témában külön tanulmány is született, lásd: Jovánovics-Pap 2013, 153-157.

${ }^{580}$ Bírósági Határozatok Gyüjtemény. http://birosag.hu/ugyfelkapcsolati-portal/anonim-hatarozatok-tara

${ }^{581}$ Miskolci Járásbíróság B.1157/2012/95, Miskolci Törvényszék Fkf.1099/2013/10, Debreceni İtélőtábla Fkhar.248/2014/7. és Miskolci Törvényszék Fk.1188/2011/217, Debreceni İtélőtábla Fkf.498/2013/13, Kúria Bhar.118/2014/11. és Pesti Központi Kerületi Bíróság Fk.27246/2010/83, Fővárosi Törvényszék Fkf.8472/2011/38, Kúria Bfv.590/2012/18.

582 Zalaegerszegi Járásbíróság B.404/2011/101, Zalaegerszegi Törvényszék Bf.152/2012/5, Pécsi Ítélötábla Bhar.247/2012/18.

583 A Helsinki Bizottság által végzett kutatás kéziratában szerepel egy eset, ahol két roma nőt bántalmaztak. Helsinki Bizottság: „A közösség tagja elleni erőszak (Btk. 174/B. §) bírósági aktaelemzéssel" címü kutatás kézirata, 5.
} 
erőszakról. ${ }^{584}$ Tehát négy ügyben romákkal szemben alkalmazták a tényállást, míg két esetben roma sértettek szerepeltek. Tekintettel arra, hogy a kisebbségvédelem lényege a hatalmi asszimetria csökkentése, az ilyen jellegü, többséget segítő kisebbségvédelem a hatalommal való visszaélés megnyilvánulása a jogalkotásban és jogalkalmazásban egyaránt.

Ezeknek az ügyeknek a több szempontból is jelentősége van a jogalkalmazásra nézve. Meglepően kevés romák ellen elkövetett közösség tagja elleni erőszak büncselekményében hozott ítéletről van tudomásunk (hozzáférésünk) az elmúlt évekből. Természetesen ezen adatok alapján messzemenő következtetéseket levonni nem lehet, de figyelembe véve a romák magyarországi helyzetét, a társadalmi és történelmi kontextust, nehezen elképzelhető, hogy mindösszesen két eset történt (juthatott el bírósági szakba). Azonban a dolgozat jelen részének nem az az elsődleges célja, hogy a romákkal szembeni gyülölet-büncselekményekkel kapcsolatban rendkívül kevés jogerős döntést egyedileg vizsgálja. Ezzel szemben mindenképp cél annak a visszaélésszerü jogalkalmazásnak $^{585}$ a vizsgálata, amelynek keretében magyarellenesség címén alkalmazzák a rasszizmus, homofóbia és más hasonló társadalmi szintü előítéletekből fakadó erőszak áldozatainak büntetőjogi védelmet nyújtani hivatott tényállást. Az ügyek lényegesen eltérő történeti tényállásaiból eredően nem az egyedi ügyek vizsgálatával foglalkozik jelen rész, hanem azzal - a korábban már tárgyalt - kérdéssel, hogy szabályozás kisebbség- vagy identitásvédő, ebből következően pedig azzal, hogy lehet-e védendő a magyar Magyarországon.

Amint arra a dolgozat korábban rámutatott, tárgyilagos mérlegelés szerinti akár ésszerü indokot képezhetne, ha a kisebbségekre szükítené le a jogalkotó a gyülöletbüncselekmények szabályozását; de nem a számszerü kisebbség értelmében, hanem a sérülékenység, a hátrányos helyzet, a történelmi tapasztalatok, a stigmatizáltság, a jelenkori társadalom elöítéletessége, valamin a rendszerszintü diszkrimináció fogalmi síkjain értelmezve. ${ }^{586} \mathrm{~A}$ konzekvens bírósági gyakorlattal ellentétben ezen álláspont szerint a nemzeti többséghez, a magyar nemzethez való tartozást Magyarországon nem

\footnotetext{
584 A dolgozat korábbi fejezeteiben már említett miskolci eset. Lásd Jovánovics-Pap 2013, 153-157. Miskolci Járásbíróság 22. B. 2418/2011, Miskolci Törvényszék 3. Bf. 2023/2012.

585 Lásd Jovánovics Eszter: Az egyik szerint garázda a másik szerint rasszista. http://ataszjelenti.blog.hu/2013/10/15/az_egyik_szerint_garazda_a_masik_szerint_rasszista (2015. március 19.)

${ }^{586}$ Ez az álláspont jelenik meg a védendő csoportokkal kapcsolatban pl. Jovánovics-Pap 2013, 156.
} 
lehetne a személyiség olyan elemének tekinteni, amely stigmatizáltságot, kiszolgáltatottságot, fenyegetettséget hordozna, és ezáltal a kiemelt büntetőjogi védelemre igényt tarthatna. Természetesen, ha például külföldön magyarsága miatt támadnak meg valakit, akkor az gyülölet-büncselekménynek minősülhet, hiszen ebben az esetben lehet kiszolgáltatott, hátrányos helyzetben a magyar nemzet tagja az ottani többséghez képest. Ezt az álláspontot támasztja alá a jogalkotói szándék is. A tényállás 2009-as módosítását megelőzően ugyanis kizárólag a nemzeti, etnikai, faji és vallási csoportokat védte a tényállás. Emellett az emberiség elleni büncselekmények, a nemzetközi jog és a joggyakorlat is azt mutatja, hogy a gyülölet-büncselekményeket szabályozó tényállások jellemzően sérülékeny csoportokkal szembeni kirekesztés, diszkrimináció elleni küzdelem büntetőjogi eszközei. 2009-ban azonban nyitott listára tért át a jogalkotó a “lakosság egyes csoportjai” tétel tényállásba iktatásával. Azonban látni kell, hogy ennek célja elsősorban a szexuális kisebbségek védett csoporttá nyilvánítása volt, mégis egy az eredeti szándékkal ellentétes jogalkalmazói gyakorlat kezdett kialakulni. ${ }^{587}$

Annak, hogy a bíróságok - álláspontom szerint - nem eredeti céljuknak megfelelően alkalmazzák a tényállást még egy oka van a fent vázolt értelmezési bizonytalanságokon kívül. Mégpedig - a már szintén említett - elsődleges és másodlagos motiváció kérdésköre. A joggyakorlat mind hazai, mind nemzetközi viszonylatban azt mutatja, hogy az előítéletes motivációnak lényegesnek, avagy elsődlegesnek kell lennie az ilyen típusú büncselekmény megállapításához. Az elöítéletes motiváció akkor tekinthető lényegesnek, ha arra a kérdésre, hogy a bűncselekmény elkövetésére az áldozat adott csoporthoz tartozása hiányában is sor került volna, a válasz nemleges. Ebből a szempontból az idézett ügyek közül a legutóbbi miskolci ügyben a Debreceni Törvényszék maximálisan egyező állásponton volt, azonban a Debreceni Ítélőtábla amely már másodszor állapította meg romák felelősségét közösség tagja elleni erőszak büncselekményében - ettől teljesen eltért döntésében.

Az ügy történeti tényállása szerint egy szakképző iskola udvarán szünetben a sértett két osztálytársával a kijelölt dohányzó helyről visszaindult az iskola épületébe. Az egyik vádlott a sértetti társasághoz lépett, míg a barátai kissé távolabb megálltak. A vádlott cigarettát kért a sértettől, aki közölte vele, hogy nem tud neki adni. A vádlott ekkor szólt

587 Jovánovics-Pap 2013, 155. 
a barátainak, hogy menjenek oda és fogják le a sértett karjait, hogy a táskáját át tudja nézni van-e abban cigaretta, illetve figyeljék, hogy nem megy-e arra tanár. A sértettet lefogták és egy doboz cigarettát vettek ki a táskájából. Ezt követően az I. r. vádlott azt a kijelentést tette a sértettre, hogy ,nézzétek a hülye kis magyar geci nem akart nekem cigarettát adni”, „,ki kellene irtani az egész fajtádat!”. Ezen kijelentés megtételével egyidejüleg leköpte a sértettet és egy alkalommal ököllel szájon vágta. ${ }^{588}$

A másodfokú bíróság a közösség tagja elleni erőszak bűntette kapcsán a motívum fennállásáról helyesen kifejtette, hogy arról akkor beszélhetünk:

"ha az elkövetöt a csoporthoz tartozó személy ellen tanúsított eröszakos magatartására nem a konkrét személlyel szembeni sérelme, hanem e személynek az adott csoporthoz való tartozása miatti ellenséges érzülete indította. Ez egyben azt jelenti, hogy a motívum lehet vagylagos is - azaz az elkövetöt cselekményére ezen ellenséges érzület mellett más körülmény is motiválhatja - azonban a cselekmény elsödleges, vezérlö motívumának a közösséghez való tartozás miatti ellenséges érzületnek kell lennie. Ez a motívum pedig nem eseti jelleggel, azaz csak a konkrét cselekvéskor, hanem állandó jelleggel van jelen az elkövetö tudatában, annak nézetrendszerében gyökerezik. Mindezek következtében a motívum feltárásakor nem mellözhetö az elkövetö általános gondolkodásmódjának, mindennapi életben tanúsított magatartásának, elözetes kijelentéseinek, illetve a cselekménnyel érintett csoport egyéb tagjaihoz való viszonyulásának vizsgálata. Vagylagos motívumok fennállása esetén tehát csak az elkövetö személyiségének megismerésekor lehet megalapozottan állást foglalni a tekintetben, hogy az elkövetöt az erőszakos fellépésre másnak valamely csoporthoz való tartozása miatti ellenséges érzülete vagy egy konkrét sérelem indította. Amennyiben ugyanis az eröszakos fellépés motívuma elsősorban egy konkrét sérelem volt, és a sértett adott csoporthoz való tartozásával összefüggésben elhangzott szidalmazás (pl. büdös magyar) mintegy az indulat levezetése körében jelentkezik, úgy közösség tagja elleni eröszak büntettéröl nem beszélhetünk." 589

Jelen ügyben a bíróság álláspontja szerint az ítéleti tényállás nem rögzített olyan adatot, amely alapján a vádlott magyarsághoz való viszonyulása tisztázható lett volna, ekként a 
magyarság elleni motiváció a vádlottra konkretizálva megállapítható lett volna. A törvényszék szerint a járásbíróság pusztán annak alapján megállapíthatónak találta a közösség tagja elleni erőszak motívumát, hogy a vádlott a sértett megütése előtt kijelentette: „Nézzétek, a hülye kis magyar geci nem akart nekem cigarettát adni! Ki kellene irtani az egész fajtádat!” A törvényszék álláspontja szerint ezen kijelentés, bár valóban negatív tartalmat hordoz a magyarsággal szemben, de nem valószínűsíti azt, hogy a vádlott azért bántalmazta volna a sértettet, mert az magyar volt. „A járásbíróság a törvényszék álláspontja szerint azért jutott ezzel ellentétes irányú következtetésre, mert csupán az elhangzott kijelentés tartalmára volt figyelemmel, a cselekmény körülményeit, a vádlott megelözö magatartását és általában a magyarsághoz való viszonyulását minthogy ezen körülményeket itéletének tényállásában sem rögzítette - semmilyen formában nem értékelte." ${ }^{590}$ A törvényszék által az eljárás során kihallgatott több tanú is vallott arra nézve, hogy a vádlott nem táplált gyülöletet a magyarsággal szemben. Több tanú is elmondta, hogy a vádlott a magyarokkal és a cigányokkal egyaránt jóban volt és soha nem hallottak tőle magyarellenes kijelentést. A törvényszék sem vitatta azt, hogy annak ellenére, hogy e tanúk vallomása tükrében előttük a vádlott soha nem tanúsított magyarellenes megnyilvánulást, nem zárható ki az, hogy a büncselekmény elkövetésekor valóban tett a magyarságot érintő negatív kijelentéseket. Ugyanakkor a tanúk vallomásai nem támasztják alá azt sem, hogy a vádlott általában véve is ellenséges érzületet táplálna a magyarsággal szemben, vagyis szemléletében is olyan negatív módon viszonyulna a magyarsághoz, hogy az cselekménye irányultságát is meghatározná. Mindezek alapján a bíróság megállapította, hogy a sértett bántalmazásának indoka a cigaretta át nem adása miatti harag volt, és pusztán az indulat levezetése körében jelentkeztek a magyarsággal kapcsolatos negatív tartalmú kijelentések. A törvényszék álláspontja szerint a járásbíróság e körben adott azon indokolása pedig, hogy a vádlott a cigaretta át nem adását azért sérelmezte, mert az a személy, aki ezt megtagadta magyar volt, feltételezésen alapul, amelyet semmilyen tény nem támaszt alá. Ezen feltételezést egyébként az is gyengíti, hogy a vádlott a cigaretta kezdeti kérésekor még semmilyen formában nem utalt a sértett magyarsághoz tartozására (pl. adj cigit, köcsög magyar! stb.), így nem bizonyítható az, hogy eleve azért választotta ki a sértettet, mert az magyar. Mindezek tükrében pedig nem lehetett kétséget kizáróan bizonyítani, hogy a vádlott erőszakos cselekményének motívuma a

${ }^{590}$ Lásd uo. 9. 
sértett magyarsághoz való tartozása volt, ezért a törvényszék a vádlottat az ellene közösség tagja elleni erőszak büntette miatt emelt vád alól felmentette. ${ }^{591}$

Ezzel szemben a Debreceni Ítélőtábla megállapította a közösség tagja elleni erőszak büncselekményét. A bíróság egyrészt újra rámutatott, hogy “az elviekben többségi társadalomhoz tartozó személyekböl álló csoport tagjai is kerülhetnek olyan helyzetbe, amikor büntetöjogi védelem illeti meg öket, amennyiben e csoporthoz való tartozás vagy vélt tartozás miatt szenvednek sérelmet". ${ }^{592}$ Másrészt kimondta, hogy a "büncselekmény megvalósulásához nem szükséges, hogy az elkövetö általában is ellenérzéssel viseltesen az adott közösség iránt, elegendö annak a konkrét cselekmény idején való tanúsítása”. A döntés alapján a bíróság egyértelműen azt az ügyészségi érvelést osztotta, hogy “amikor a sértettel szemben sértő kifejezést használt, leköpte, illetve állon is ütötte öt, mely a sértett megalázására irányult, a vagyon elleni eröszakos büncselekmény mellett ezt már egy nemzeti csoporthoz tartozása miatt tette, mely többletcselekményként értékelhetö". 593

Álláspontom szerint a Debreceni Ítélőtábla újfent - téves bírói értékelésből fakadóan helytelenül alkalmazta a közösség tagja elleni erőszak tényállását. A fentiek fényében továbbra is azt az álláspontot képviseli a dolgozat, hogy a magyarság Magyarországon nem tekinthető sérülékeny csoportnak és ebböl kifolyólag nem jogosult a közösség tagja elleni erőszak tényállásában biztosított előítéletből fakadó erőszakos cselekményekkel szembeni védelemre. Az ilyen jellegü cselekményekkel szemben a Btk. más tényállásai biztosítanak védelmet a nem sérülékeny csoportok számára. Másrészt a Debreceni Ítélőtábla figyelmen kívül hagyta a másodfokú bíróság vagylagos motívumra vonatkozó érvelését is. Álláspontom szerint arra a kérdésre, hogy a büncselekmény elkövetésére az áldozat adott csoporthoz tartozása hiányában is sor került volna, a válasz egyértelmúen pozitív. Ennek következtében pedig nem lehet a motivációt elsődlegesnek tekinteni. Mindebből egyértelmü, hogy a fenti torz jogalkalmazási irány egyrészt a törvény (és jogalkotói szándék) nem megfelelő értelmezéséből, valamint a vagylagos motiváció megállapításának nehézségeiből fakad. Mindezek végső soron a tényállás teljes kiüresedéséhez vezetnek, amely éppen az alkotmányos kisebbségvédelmet számolja fel.

A problémára az alapvető jogok biztos is felhívta a figyelmet egy jelentésében. A biztos kiemelte, hogy tudomásom szerint 2013-ig a gyülölet-büncselekményre vonatkozó Btk.

\footnotetext{
${ }^{591}$ Miskolci Törvényszék, Fkf.1099/2013/10.

592 Debreceni Ítélőtábla, Fkf.I.498/2013/13. 9.

593 Lásd uo.
} 
tényállás alapján, Magyarországon kizárólag roma nemzetiségü magyar állampolgárokat ítéltek el. Amint arra a biztos már az új Btk. kodifikációja során is felhívta a jogalkotó figyelmét, „a gyülölet-büncselekmény tényállása, pontosabb megfogalmazása esetén, kevesebb vitára adna alkalmat az igazságszolgáltatás szereplöi számára, azonban a tényállásnak már jelenleg is egyértelmüen az érzékeny társadalmi csoportok védelme lenne a valódi feladata. Az a tény, hogy ezt a szakaszt a büntetö birák a többségi társadalom tagjának sérelmére elkövetett büncselekmény esetén is érvekkel alátámasztva - használhatják, önmagában ellentmond minden általam ismert, a kisebbségvédelem terén kialakított szakmai és tudományos álláspontnak."594

\subsection{A romák ellen irányuló gyilkosságsorozat}

A téma komplexitásából eredően csupán részben a jogalkalmazáshoz tartozó kérdés, de a magyarországi jogalkotás és jogalkalmazás kapcsán mindenképp szükséges - ha terjedelmi és módszertani szempontból csupán említés szinten is - a romák ellen irányuló támadássorozatról szót ejteni. Illetve a téma - később részletezett - rendkívül szerteágazó volta miatt elöször röviden az általános társadalmi háttér ismertetése is elengedhetetlen, kiváltképp a romákkal kapcsolatos társadalmi attitüdök és az ezekkel kapcsolatos kutatási eredmények áttekintése. Éppen ezért a dolgozat a jogi szabályozás és a joggyakorlat elemzését követően más társadalomtudományi területeket is érint a továbbiakban.

A kisebbségek ellen elkövetett gyülölet-büncselekmények már-már mindennaposak Európában, a tapasztalatok szerint Európában a menedékkérők, a bevándorlók, a menekültek, a zsidók, a muszlimok és a romák válnak leggyakrabban gyülöletbüncselekmények áldozataivá. 595

2008 óta Csehországban, Magyarországon és Olaszországban a romák ellen irányuló erőszak egyre inkább komolyabb és növekvő problémát jelent, de a romák más országokban is fokozottan válnak erőszakos cselekmények áldozatává. Az EBESZ Demokratikus Intézmények és Emberi Jogok Hivatalának fötanácsosa megállapításai szerint a romák házai és személye elleni fizikai erőszak, rasszista sértések, rongálások

\footnotetext{
${ }^{594}$ Az alapvető jogok biztosának jelentése az AJB-1199/2013. számú ügyben. 2013. 59.

595 Minority Rights Group International: Annual survey urges European governments to combat hate crime towards minorities. 3 July 2014. http://www.minorityrights.org/12489/press-releases/annualsurvey-urges-european-governments-to-combat-hate-crime-towards-minorities.html (2015. június 2.)
} 
és rendőri erőszak a legjellemzőbbek a jelentett bủncselekmények körében. A jelentett büncselekmények egy része halállal végződött és nem ritka, hogy a támadások családok vagy szegregált lakókörnyezetben élő teljes közösségek elleni irányulnak. ${ }^{596}$ Magyarországon legalább 48 erőszakos támadást regisztráltak, kilenc halálos áldozattal 2008 januárja és 2010 júliusa között. ${ }^{597}$

A 2008-as gazdasági világválság és a megszorító kormányintézkedések hatására Európa szinte minden országában tovább fokozódtak a bevándorlókkal, menekültekkel, romákkal, zsidókkal szembeni ellenérzések. Mindez pedig sokszor erőszakban és gyülöletben ölt formát. ${ }^{598} \mathrm{Az}$ indulatok ilyen irányú „,csatornábaterelését” támasztja alá Glick modellje, miszerint akkor jön létre a bünbakként kiválasztott csoport iránt agresszió, amikor társadalmi válság idején olyan politikai ideológia jelenik meg, amely igyekszik elhitetni az emberekkel, hogy az adott csoport az oka a krízisnek. A bünbakképző ideológiák azért válhatnak vonzóakká a társadalom egyes csoportjai számára, mert könnyen érthető magyarázatot és megoldást kínálnak komplex helyzetekben. Ezen felül a bünbakképzés megoldást is javasola válságra: a csoporttal szembeni jogfosztó, illetve erőszakos lépéseket is. ${ }^{599}$ Nem véletlen, hogy a gyülöletbüncselekmények esetében nem csupán az egyén és védett csoport, hanem a teljes társadalom szintjén érzékelhetőek a hatások. A gyülölet vezérelte erőszak több mint néhány, adott esetben rasszista egyén megnyilvánulása: normarendszereket, társadalmi feltételezéseket, magatartásokat, elveket jelképez, amelyek a faji és nemi egyenlőtlenségek újratermelésére, hierarchikus viszonyok fenntartására irányulnak. Az elkövetők az elnyomó erőszakot alkalmazzák saját megerősítésükre, annak érdekében, hogy nekik kedvező rendet alakítsanak ki. Az erőszak a hatalom iránti vágy megnyilvánulási formája, amely megfosztja az elnyomottat szabadságától és méltóságától, ${ }^{600}$ azaz megfosztja emberi jogaitól - adott esetekben akár az életétől is. ${ }^{601}$

\footnotetext{
${ }^{596}$ Michael Stewart: Foreword: New Forms of Anti-Gypsy Politics: A Challengefor Europe. In Michael Stewart (szerk.): The Gypsy 'Menace'. Populism and the New Anti-Gypsy Politics. London: Hurst \& Company. 2012. xiv.

597 Lásd uo. xiv.

${ }_{598}^{59}$ Minority Rights Group International 2014.

599 Kovács Mónika: „Az előítéletek okai és mérséklésük lehetőségei: a szociálpszichológiai nézőpont"Alkalmazott pszichológia, 2010/1-2. 10.

${ }^{600}$ Perry - Olsson 2009, 181.

601 A fenti elméleteknek a gyülölet-büncselekmények jogi szabályozása kapcsán is kiemelt jelentősége van. Amikor a jogalkotó a védett csoportok kialakítását illetően dönt, akkor mindenképp érdemes figyelembe venni, hogy az adott társadalomban melyek azok csoportok, amelyek ilyen rendszerszintü erőszaknak áldozataivá válhatnak.
} 
A gyülöletvezérelte büncselekmények e jellemzőihez kapcsolódóan, az erőszak eszkalálódásának $^{602}$ szemléltetésére alkalmazzák - föként oktatási célokból - a „gyülöletpiramis”-t. ${ }^{603} \mathrm{~A}$ piramiselmélet lényege, hogy az elöítélet-vezérelte cselekmények megnyilvánulási formái egymásra épülnek és olykor egy adott csoport teljes vagy részleges megsemmisítésére, elnyomására irányuló erőszakban csúcsosodnak ki. A piramis egyes elemei: előítéletek, sztereotípiák, gyülölködő megnyilvánulások, gyülöletincidensek, uszítás, gyülölet-büncselekmények, népirtás és apartheid. Ez alapján minden gyülölet-büncselekmény alapját az elöítéletek képezik. Ezt pedig az elöítélet-vezérelte büncselekmények fogalmával kapcsolatos alapvető nézetek is alátámasztják, miszerint elegendő, hogy a gyülölet-büncselekmény mozgatórugója az elöítélet, amely nem feltétlenül az elkövető által érzet elöítéletben nyilvánul meg, hanem a társadalomban meglévő elöítéletekre alapoz. ${ }^{604}$

Magyarországon a tapasztalatok szerint a gyülölet-büncselekményeknek leginkább kitett csoportok a romák, az leszbikus, meleg, biszexuális és transznemü emberek (LMBT), a menekültek, a bevándorlók és a zsidók. ${ }^{605}$ Egyre több esetben hallani hajléktalanok elleni erőszakos cselekményekről is. ${ }^{606}$ Ezt támasztják alá az elmúlt évek gyülölet-büncselekményekkel kapcsolatos nyomozati tapasztalatok is: legáltalánosabb gyülölet-motivációk közé a cigányellenesség és a homofóbia tartozik. ${ }^{607}$

A roma közösség Magyarország legnagyobb kisebbségi csoportja. A 2011-ben végzett népszámlálás adatai szerint 315 ezren vallották magukat cigány (roma) nemzetiséghez tartozónak, mintegy másfélszer annyian, mint 2001-ben. ${ }^{608}$ Ezzel szemben a reprezentatív felmérések 1971-ben 320 ezer fö körülire, 1993-ban 468 ezer körülire, 2003-ban pedig mintegy 570 ezerre becsülték a cigányok számát. Ez az ország teljes

${ }^{602}$ Ld. pl. Chris Chapman: „The Role of Hate Speech and Hate Crime in the Escalation of Identity Conflict" in Peter Grant (szerk.): State of the World's Minorities and Indigenous People 2014. Minority Rights Group International. 34-39.

603 Anti-Defamation League: Pyramid of Hate. http://www.adl.org/assets/pdf/educationoutreach/Pyramid-of-Hate.pdf (2015. augusztus 4.)

${ }^{604}$ Balogh - Pap 2011, 129.

605 Lásd pl. Index: Fiatalkorúak rugdostak meg egy hajléktalant. 2013. http://index.hu/belfold/2013/11/16/fiatalkoruak_rugdostak_meg_egy_hajlektalant/ (2015. július 20.) illetve HVG: Feljelentésen gondolkodik a pályaudvaron verekedö örök ügyvédje. 2015. http://hvg.hu/itthon.bunugy/20150421_palyaudvaron_verekedo_orok (2015. július 20.)

${ }^{606}$ TASZ: A Társaság a Szabadságjogokért álláspontja a gyülölet-büncselekmények szabályozásáról. 2015. http://tasz.hu/files/tasz/imce/tasz-gybcs-allaspont-final_.pdf (2015. június 2.)

${ }^{607}$ GYEM által kezdeményezett közérdekủ adatigénylés keretében rendelkezése bocsátott jelentés. ORFK: 2011-2013-as időszakra vonatkozó jelentés, 29000/6903-2/2015. Ált. 6.

608 Központi Statisztikai Hivatal: 2011. évi népszámlálás. 3. Országos adatok. 7. http://www.ksh.hu/docs/hun/xftp/idoszaki/nepsz2011/nepsz_orsz_2011.pdf 2015. augusztus 4.) 
népességéhez viszonyítva közel 5,5 százalékos arányt jelentett. ${ }^{609}$ Kutatói becslések a romák számát 2010-es évekre $650-750$ ezer közé tették. ${ }^{610}$ A magyarországi roma lakosságot társadalmi és gazdasági marginalizáció, valamint lakhatási és iskolai szegregáció egyaránt sújtja. Emellett jóval magasabb a munkanélküliség és szegénység a roma lakosságon belül. ${ }^{611}$ A Világbank 2005-ös jelentése szerint, a szegénység a romák körében eléri a 26,3\%-ot - amely hétszerese a nem romákat érintő 3,6\%-os szegénységi rátának. ${ }^{612}$

Magyarországon már az 1980-as években is folytak empirikus vizsgálatok az etnikai elöítéletek témakörében, föképpen a nemzeti identitás és a csoportsztereotípiák kutatása kapcsán. A rendszerváltás negatív társadalmi-gazdasági hatásai a legnagyobb lélekszámú magyarországi kisebbséget, a romákat különösen kedvezőtlenül érintette. ${ }^{613} \mathrm{~A}$ felnőtt lakosság nemzeti identitása a kisebbségekhez való viszonytükrében leginkább akképp írható le, hogy az emberek legnagyobb részének nemzeti identitása nem abban nyilvánul meg, hogy elfogadná a „nemzeti” ideológiát vagy a nemzetkarakterológia magyarságképét, hanem abban, hogy más etnikumokhoz, így a hazai kisebbségekhez képest hogyan határozza meg magát. ${ }^{614}$

A romákkal szemben nagyon erős elöítéletek élnek a közvéleményben, amelyek intenzitása változó képet mutat a rendszerváltás óta. 1987-es és 1992-es adatokat összehasonlítva mérséklődő előítéletesség figyelhető meg; a romákkal kapcsolatban

${ }^{609}$ Nemzeti Társadalmi Felzárkózási Stratégia - mélyszegénység, gyermekszegénység, romák - (20112020). KIM Társadalmi Felzárkózásért Felelős Államtitkárság. Budapest, 2011. 24. http://romagov.kormany.hu/download/8/e3/20000/Strat\%C3\%A9gia.pdf (2015. augusztus 4.)

${ }^{610}$ Lásd uo. 24.

${ }^{611}$ Ld. pl. Paul Iganski: „Regional overviews. Europe” in Peter Grant (szerk.): State of the World's Minorities and Indigenous People 2014. Minority Rights Group International. 162-187.; Havas Gábor Kertesi Gábor - Kemény István: „The Statistics of Deprivation. The Roma in Hungary”Hungarian Quarterly, 36. 1995. No. 1. 67-80.; Nemzeti Társadalmi Felzárkózási Stratégia 2011. 24-29.; FRA: Esettanulmány. A romák lakóhelyi szegregációja elleni küzdelem, Magyarország. 2009. http://fra.europa.eu/sites/default/files/fra_uploads/602-ROMA_Housing_Case-final-HU.pdf (2015. július 10.)

612 Amnesty International: Erőszakos támadások a romák ellen Magyarországon. Itt az idő a rasszista indíték $\quad$ kivizsgálására. $2010 . \quad 10 . \quad$ http://www.amnesty.hu/data/file/1279eroszakos_tamadasok_a_romak_ellen_eur270012010hu.pdf?version=1415642342 (2015. augusztus 1.)

613 Enyedi Zsolt - Fábián Zoltán - Sik Endre: „Nőttek-e az előítéletek Magyarországon? Antiszemitizmus, cigányellenesség és xenofóbia változása az elmúlt évtizedben” in Kolosi [et al.] (szerk.): Társadalmi riport 2004. Budapest: TÁRKI, 375-399. http://www.tarki.hu/adatbankh/kutjel/pdf/a809.pdf (2015. augusztus 1.)

614 Lázár Guy: „A felnőtt lakosság nemzeti identitása a kisebbségekhez való viszony tükrében” in Terestyéni Tamás (szerk.): Többség - kisebbség. Tanulmányok a nemzeti tudat témaköréböl. Budapest: Osiris - MTA-ELTE Kommunikációelméleti Kutatócsoport, 1996. 96. 
említett kedvezőtlen vonások aránya összesen 80\%-kal csökkent, a kedvezőké pedig $17 \%$-kal nőtt az említett időszakban. ${ }^{615}$

A romákkal szembeni előítéletek nem sok változást mutatnak azonban a 2000-es évek eleje óta. A Tárki 2000 óta vizsgálja a romákkal szembeni elöítéleteket. 2000 és 2005 közötti adatok azt mutatják, hogy az ezredfordulókor igen erősek voltak a romákkal szembeni előítéletek. A felmérések során olyan állítások mérték a romákkal kapcsolatos elöítéletek alakulását, amelyek a bünözés és az etnikai hovatartozás feltételezett összefüggésére vonatkoztak, a szociális ellátások elosztására, valamint a romák munkával kapcsolatos feltételezett attitüdjeire kérdeztek rá. A leglényegesebb változás a bünözési hajlammal kapcsolatban figyelhető meg: míg 2000-ben a válaszadók 55\%-a és 2002-ben 53\%-a értett egyet azzal az erőteljes rasszista állítással, hogy a „bünözési hajlam a romák vérében van”, ez az arány 2005-re 62\%-ra nőtt. ${ }^{616}$ A „,cigánybünözés” közbeszédben való radikális elterjedésének jelenségére reagálva az Országos Kriminológiai Intézet 2009-ben „Állásfoglalás a magyarországi bünözési helyzetről, az elkövetők etnikai hovatartozásának nyilvántartásáról és a »cigánybünözésrőll" címmel dokumentumot bocsátott ki; rámutatva, hogy az „etnikai hovatartozásra vonatkozó adatrögzítésre sem a bünüldözés, sem az igazságszolgáltatás, sem a büntetésvégrehajtás során nem kerül sor, ilyen adatnyilvántartás ma nem létezik. Így az egyes etnikai csoportokhoz tartozó bünelkövetök vagy cselekményeik számszerü alakulására vonatkozó állitások és feltételezések jogszerüen gyüjtött és feldolgozott tényadatokkal nem támaszthatóak alá”. Mindezek fényében pedig , a romákkal kapcsolatos bünügyi arányszámokra vonatkozó állítás csupán találgatás, személyes benyomásokon alapuló szubjektív észlelet, nem pedig megalapozott következtetés a Magyarországon élö roma kisebbséggel kapcsolatban. A »cigánybünözésröl« fogalmának használata oksági kapcsolatot feltételez a cigány származás és a bünelkövetési gyakoriság között. Olyan, bünbakképzésre alkalmas tartalmakat közvetit, amely a cigány kisebbség egészét méltatlan helyzetbe hozza, az elöitéleteket és indulatokat pedig tovább szítja." "617 Végül az állásfoglalás arra a rendkívül fontos tényre is rámutatott, hogy ezt a jelenséget nem

\footnotetext{
${ }^{615}$ Lázár Guy: „A kisebbségek szerepe a nemzeti identitás kialakulásában”Regio - Kisebbség, politika, társadalom. 1995/1-2., 28-63. ill. Koos Postma: „A cigányokkal szembeni előítélet alakulása Magyarországon”Regio-Kisebbség, politika, társadalom. 1998/1., 109-127. (ford. Victor Mónika) 616 Tárki: Továbbra is erös roma-ellenes elöitéletek. 2006. http://www.tarki.hu/tarkitekinto/20060201.html (2015. augusztus 7.)

617 OKRI: Állásfoglalás a magyarországi bünözési helyzetröl, az elkövetök etnikai hovatartozásának nyilvántartásáról és a „cigánybünözésről. Budapest: Országos Kriminológiai Intézet, 2009. 2-3.
} 
hatástalanítják időben, azaz nem törekszenek a jelenség mögötti valós problémák rendezésére vagy enyhítésére, az beláthatatlan következményekkel járhat. „A tragédiák megelözéséhez vezetö felelös büntetőpolitikához a valós helyzetet feltáró kutatásokra és az ezek eredményeinek elemzésén nyugvó hatásos intervenciókra lenne szükség."618

A Medián Közvélemény- és Piackutató Intézet felmérése alapján a romákon kívül nincs még egy csoport Magyarországon, amelyik iránt hasonlóan sokan vállalnák nyíltan legmélyebb ellenszenvüket. A felnőttek több mint egyharmada (38\%) a skála legnegatívabb értékével fejezte ki, mit gondol a romákról. Az adatok azt mutatják, hogy „a cigányokhoz való viszony elsősorban az egyén világnézeti-ideológiai beállítottságán és ezen belül is a leginkább azon múlik, hogy hol helyezi el magát egy baloldalijobboldali skálán: minél közelebb van a jobbszélhez, annál valószínübb a negatív attitüd. Világnézettől és származástól függetlenül a falun élök és a legkisebb jövedelmüek nézik a legkevésbé ferde szemmel a cigányokat. ${ }^{" 619}$ Az említett időszakban határozottan nőtt a jellegzetesen rasszista álláspontot képviselök aránya. A legnagyobb mértékben a romákat kitelepíteni vágyók száma gyarapodott: amíg 2001-ben még 29, 2009-ben már 36\% szeretné a cigányokat „elkülöníteni a társadalom többi részétől”. ${ }^{620}$ A Medián megállapításai szerint, amíg Nyugaton különféle módszerekkel próbálják tetten érni az emberek úgynevezett látens rasszizmusát, addig Magyarországon az emberek közel hattizede a kérdezőbiztos előtt is vállalja, hogy szerinte „a cigányok vérében van a bünözés", 621

A Tárki 2011-es felmérése szerint a magyar lakosság 63\%-a genetikai meghatározottságnak véli a romák bünözési "hajlamát". A jobbikosok 79\%-a pedig részben vagy teljes mértékben egyetért azzal, hogy a ,cigányoknak a vérükben van a bünözés". Emellett kétharmados többségben vannak azok, akik nem fogadnák el, hogy gyermekük roma gyerekkel barátkozzon. A nemzetközi radikalizmus-indexen a vizsgált 33, többségében uniós ország között Magyarország az ötödik helyen áll, a (negatív) listavezető Törökország, míg az utolsó (azaz a legkevésbé radikális) ország Izland. ${ }^{622}$

\footnotetext{
618 Uo. 3.

619 Medián: Fagypont körül. 2009. http://www.median.hu/object.2a6fb495-9b95-4bb7-89ff1a5942f27c9f.ivy (2015. augusztus 7.)

${ }^{620}$ Lásd uo.

${ }^{621}$ Lásd uo.

622 Origo: Tárki: A magyarok többsége nem akarja, hogy cigányokkal barátkozzon a gyereke. 2011. http://www.origo.hu/itthon/20111205-a-tarki-felmerese-az-idegengyuloletrol.html (2015. augusztus 11.)
} 
Az elöítéletek a médiában és a politikában is fokozottan megjelennek. A radikális jobboldali populista párt (Jobbik) nyíltan használ romaellenes, homofób és idegenellenes gyülöletbeszédet. Amint azonban az ECRI ötödik jelentésében rámutatott, a gyülöletbeszéd nem korlátozódik szélsőséges pártokra és csoportokra, hanem a teljes politika palettán megtalálható. ${ }^{623}$ Állami tisztségviselőknek és vezető politikai pártoknak is voltak ilyen megnyilvánulásaik. Például egy ismert újságíró - a Fidesz egyik társalapítója és tagja - tollából a Magyar Hírlapban 2013 januárjában olyan cikk jelent meg, amelyben a romák egy jelentős részét ,állatoknak” nevezte. Emellett az igazságszolgáltatás sem mentes az elöítéletektől: 2014 márciusában, a Gyulai Törvényszéken az eljáró bíró akként indokolta egy döntését - amelyben elutasította a Szebb Jövőért Polgárőr Egyesület feloszlatását a Gyöngyöspatán 2011-ben kifejtett romaellenes tevékenységeikért - hogy közben sztereotip és lealacsonyító megjegyzéseket tett a „cigánybünözésröl” és a roma életmódról. ${ }^{624}$

A több évtizedes, széles körben megjelenő és mélyen gyökerező elöítéletek erőszakos cselekményekben is manifesztálódnak Magyarországon a romákkal szemben. A romák elleni rasszista erőszak Magyarország egyik legidőszerübb problémájának tekinthető. Az erőszak elkövetői között egyaránt vannak szélsőséges csoportok és fajgyülölet által motivált magánszemélyek. 2008. január és 2012. szeptember között az ECRI adatai szerint 61 különböző támadást intéztek roma személyek, illetve otthonaik ellen, Molotov-koktélokkal, kézigránátokkal és lőfegyverekkel. Ezek a támadások kilenc ember életét oltották ki, köztük két kiskorúét, és több tucat sebesülést okoztak. ${ }^{625} \mathrm{~A}$ támadások közül a leghírhedtebbek „romagyilkosságok” néven ismeretesek. 20082009-ben 14 hónap alatt kilenc különböző támadás történt, hat romát gyilkoltak meg, többen pedig súlyosan megsebesültek. ${ }^{626}$

Ami az események társadalmi hátterét illeti, Bócz Endre - már hivatkozott önéletrajzi könyvében - kitér a gyülölet-büncselekmények „fejlödéstörténetére”, rámutatva a rendszerben rejlő hibákra, alátámasztva a gyülölet-büncselekmények elöítéletekből

\footnotetext{
${ }^{623}$ Ld. ECRI ötödik jelentés. 17.

${ }^{624}$ Ld. ECRI ötödik jelentés. 17-19.

${ }^{625}$ ECRI Magyarországról szóló negyedik jelentése (ECRI Report on Hungary, fourth monitorting cycle) CRI (2009) 3, 2009. 24. para 54. http://www.coe.int/t/dghl/monitoring/ecri/Country-bycountry/Hungary/HUN-CbC-IV-2009-003-HUN.pdf (2014. február 19.)

${ }^{626}$ Lásd például Tábori Zoltán: Cigány rulett, Budapest: Európa Könyvkiadó, 2014.
} 
fakadó, eszkalálódó jellegét. ${ }^{627}$ Bócz szerint a 80-as években megindult előítéletmotiválta rongálások és testi sértések - amelyeknél az elöítélet-motivációt rendre nem alkalmazták - Magyarország elmúlt évtizedeinek legkegyetlenebb gyülöletbüncselekményeiben csúcsosodtak ki, a romák elleni támadássorozatban: A nyolcvanas évektől

„Az ügyeket a biróságon sorra más minősitéssel zárták; rendszerint garázdaságnak, jobb esetben aljas indokból elkövetett súlyos testi sértésnek minösitették a büncselekményt. Kimondták inkább még azt a jogi képtelenséget is, hogy a »nemzeti, avagy faji csoporthoz tartozás« mint a bántalmazás indoka a törvényben szereplö »aljas indok«-hoz képest nem speciális. [...] A hosszú viszály különös módon ért véget. A rendszerváltozás körüli időben - 1989-1992-ben - a gyülölet középpontjába már a cigányok álltak. [...] Ma már Tatárszentgyörgy után, nem tudok szabadulni attól a gondolattól, hogy ezeknek az eseményeknek az akkor még zsenge gyökereit valamikor régen, a skinhead-ügyek idején talán el lehetett volna vágni." "628

A romák elleni támadássorozat - ezen belül is elsősorban a tatárszentgyörgyi eset - több szempontból is kiemelt figyelmet kapott (a hazai sajtó és média nagy terjedelemben foglalkozott föként a tatárszentgyörgyi kettősgyilkossággal; civil szervezetek, politikusok, magánszemélyek sokasága szólalt meg az ügyben stb.). Az okok között természetesen a büncselekmény természete az egyik legmeghatározóbb; az Országgyülés Nemzetbiztonsági Bizottsága által 2009. november 17-én készített ténymegállapító vizsgálat ${ }^{629}$ a magyar kriminalisztika eddigi legsúlyosabb büncselekmény-sorozatának nevezete a gyilkosságokat, amelyeket fajgyülöletből követtek el. Már a különösen kegyetlen, kiskorú sérelmére elkövetett halált okozó gyülölet-büncselekmény ténye is kirívóvá teszi az esetet az elmúlt évtizedek büncselekményeihez képest, azonban az elmúlt évtizedek legkegyetlenebb romák elleni erőszakos büncselekménye azért is került a figyelem középpontjába, mert sokan (jogvédő szervezetek, politikusok, kisebbségi képviselők, családtagok stb.) aggasztónak

${ }^{627}$ Bócz 2010.

${ }^{628}$ Lásd uo. 378-383.

${ }^{629}$ Ténymegállapító vizsgálati jelentés. A romák sérelmére elkövetett sorozatgyilkosság felderítésére irányuló nyomozást segitő nemzetbiztonsági szolgálati munka értékelése az Országgyülés Nemzetbiztonsági Bizottsága által felállított Tényfeltáró Munkacsoport vizsgálati munkája alapján. 2009. http://www.parlament.hu/internet/plsql/ogy_biz.keret_frissit?p_szerv=\&p_fomenu=20\&p_almenu=26\&p _ckl=38\&p_biz=A277\&p_rec=\&p_egys=\&p_nyelv=-HU (2015. július 25.) 
tartották, ahogyan a hatóságok a helyszínen eljártak, ahogyan a sajtónyilatkozataikban kezelték az ügyet, valamint a lakosságot sem tájékoztatták sokáig használtható, érdemi információkkal az ügyben. ${ }^{630}$

A médiahatóság vizsgálata szerint is az üggyel kapcsolatos leghosszabb összeállítások mindegyik műsorban nem magáról a támadásról, hanem a helyszínelésnél (elsősorban a rendőrök, kisebb mértékben az ügyeletes orvos és a tüzoltók által) elkövetett szakmai hibákról és azok hatósági magyarázatairól szóltak. ${ }^{631}$

Tatárszentgyörgyön „éjfél után 2009. február 22-éröl 23-ára virradóra az otthon pihenő J. Renáta éles durranásokat hallott. Mint később kiderült, ezek a házukra hajitott molotovkoktélok hangjai voltak. Elöször két éles becsapódás hangját észlelte, majd a harmadikat már akkor, amikor már kirohant a házból kisfiával, Mátéval. Az első két durranás után J. Renáta élettársa, Cs. Róbert felkapta a két nagyobbik gyermeküket, Robikát és Biankát, Robikát a melléhez szorította, Biankát az oldalán vitte ki a házból. Menekülés közben rájuk löttek, és valószínüleg ekkor Cs. Róbert Biankát letette vagy elejtette, a kislány pedig visszafutott a házba. Ezt követöen, amikor J. Renáta a harmadik gyermeküket, Mátét vitte ki a házból, a kislány is átjutott a szomszédhoz."632 Cs. Róbert és fia - Robika - életét vesztette a helyszínen.

A Kormány vizsgálatot rendelt el a rendőrség, tüzoltóság és mentőszolgálat munkájának értékelésére, az ezzel kapcsolatban három minisztérium közremüködésével készült jelentésről 2009. március 11-én adott tájékoztatást a kormányszóvivő. A megállapítások szerint a tüzoltók és a helyszínre érkező mentők szakszerűen jártak el, bár mindkét mentőegység az elvárhatónál hosszabb idő alatt tette meg az utat; hogy ez miért történt, annak megállapítására az egészségügyi miniszter vizsgálatot kezdeményezett. A tájékoztatás szerint a tűzvizsgálóval szemben is fegyelmi eljárást kezdeményeztek, ugyanis vélhetően nem kellő körültekintéssel, még a tüzvizsgálat lezárulta előtt állapította meg, azaz vélelmezte a tűz keletkezési okát, és csak két nappal később rendelt ki független tüzvédelmi szakértőt. A jelentés szerint a dabasi bünügyi

\footnotetext{
${ }^{630}$ Európai Roma Jogok Központja (ERRC) - Nemzeti és Etnikai Kisebbségi Jogvédő Iroda (NEKI) Társaság a Szabadságjogokért (TASZ): Jelentés a 2009. február 23-án, Tatárszentgyörgyön történt kettös gyilkosság körülményeiröl és az eljáró hatóságok munkájáról. Budapest. 2009. 65. http://dev.neki.hu/wpcontent/uploads/2013/05/tat\%C3\%A1rszentgy\%C3\%B6rgyi-jelent\%C3\%A9s.pdf (2015. július 28.)

${ }^{630}$ ERRC-NEKI-TASZ 2009.

${ }^{631}$ NMHH Médiatanács 2013. 47.

${ }^{632}$ ERRC-NEKI-TASZ 2009. 65.
} 
osztályvezető megszegte a helyszínelés szabályait. A jelentés teljes szövegét nem hozták nyilvánosságra. ${ }^{633} \mathrm{~A}$ civil szervezetek által készített jelentés szerint ${ }^{634}$ amelyhez a családtagoktól, szomszédoktól és helybéliektől a helyszínen gyüjtött adatokat, a hatóságok sajtó-nyilatkozatait, valamint a vonatkozó jogszabályokat használták fel - a rendőrség értesítésekor a hívó tűzről és sérültekről számolt be. A rendőrségnek a helyszínre érkezésekor arról volt információja, hogy egy családi ház tetőszerkezete ég, több súlyos sérült van, közülük ketten elhunytak, mindkettőjükön vérző sebek voltak. Az áldozatokat nem a házban, hanem a bejárati ajtótól 6-8 méterre találták meg a hozzátartozók, égési sérülések nem voltak láthatóak rajtuk. Amikor a rendörök kiérkeztek a szomszédok rögtön tudomásukra hozták, hogy lövéseket hallottak. Az áldozatokat ellátó egészségügyi személyzet azonban nem tudta pontosan megmondani a sérülések okát. A tüzvizsgáló szerint a tüz a tetőtérben keletkezett. A rendőrök a kiégett házban elvégezték a helyszínelést, az udvarból lefoglaltak egy benzineskannát, de a bejárati ajtó mellett talált üvegtörmeléket otthagyták. Annak ellenére, hogy a tüzoltók állítólag a helyszínen a tüz keletkezési okaként elektromos tüzet jelöltek meg a rendőrségnek a helyszínre érkezést követően kötelessége lett volna a területet, és nem csak a házat lezárni, a helyszínt biztosítani, azt azonban nem tették meg. Mivel nem lehetett kizárni büncselekmény - emberölés - elkövetését, így a helyszínbiztosítás és a tanúkutatás és adatgyüjtés haladéktalan elrendelése és elvégzése is rendőri kötelezettség lett volna. Abban az esetben is, ha az eseményeket „csak” balesetnek gondolták, a helyszínt akkor is biztosítani kellett volna, ez azonban nem történt meg. A család reggel újra telefonált a rendőrségre, hogy lőszereket találtak, és a dabasi rendőrség ismét kivonult, továbbra is késlekedtek a helyszín biztosításával, és utána nem kellő nagyságú körzetben zárták le a területet. Arról sem volt információ, hogy történt-e hivatalos jelentés a dabasiak részéről a Pest Megyei Rendőrfőkapitányság felé az életellenes cselekmény gyanújáról, vélhetően nem, mivel a helyszínen Kocsis István kapitányságvezető-helyettes úgy nyilatkozott a töltények megtalálása után is, hogy nem történt büncselekmény. A jelentés szerint még az NNI helyszíni szemléjének befejezése után is újságírók találtak a ház környéki bokrokban sörétgolyókat, ebböl pedig arra lehet következtetni, hogy a nyomrögzítés még ekkor sem volt megfelelő. ${ }^{635} \mathrm{~A}$ családtól származó és a sajtóban megjelent információk szerint is a tüzoltók félrevezető

\footnotetext{
${ }^{633}$ ERRC-NEKI-TASZ 2009. 70.

634 Lásd uo.

${ }^{635}$ Lásd uo. Rendőri intézkedések értékelése 68-69.
} 
tájékoztatást adtak a helyszínen a tüz okáról (azt első körben elektromos tüzként jelölték meg). Velikovszki Zoltán dabasi tűzoltóparancsnok 2009. február 23. esti nyilatkozata szerint az első vizsgálat alapján „vélelmezetten elektromos energia jöhet számításba”, és a tüzoltók tévedése miatt burkoltan a családot okolta: „bosszant bennünket, hogy találtunk egy 10 literes benzines kannát az épület mellett, de nem tudtam információt kapni, hogy ez a tulajdonosnak a saját kannája, vagy pedig ez elözöleg nem volt a helyszínen”. ${ }^{636}$ Ezt követően a tüzoltóság kommunikációjában az „elektromos zárlat okozta a tüzet” kijelentés „,nem zárható ki az elektromos tüz” megfogalmazássá szelídült rövidúton. A mentőszolgálat indokolatlanul hosszú idő alatt értek a helyszínre. Ezzel kapcsolatban az Országos Mentőszolgálat szóvivője egy müsorban annyit mondott, hogy ,ahogy tudtak, siettek...”. ${ }^{637}$ A halottszemlét a kiérkező ügyeletes orvos 3 óra körül kezdte meg, az áldozatok teljes ruházatban voltak, amely felveti annak lehetőségét, hogy a mentősök a sérültek ruháját nem vették le, így testfelületüket, esetleges sérüléseiket nem is volt lehetőségük megvizsgálni. Az ügyeletes orvos a halottvizsgálati bizonyítványon a sérüléseket valóban leírta, azonban a vizsgálat indokaként lakástüzben elszenvedett halált tüntetett fel. Hatósági eljárást tartott szükségesnek, ami jogszabály szerint rendkívüli halálesetnél elöírás. Amennyiben a halottvizsgálatot végző orvos szerint büncselekmény elkövetésének gyanúja merül fel, nem hatósági eljárást, hanem a büntetőeljárás szabályai szerinti igazságügyi orvosi boncolást kell elrendelni (az egészségügyről szóló 1997. évi CLIV. törvény 217-218. §a alapján). ${ }^{638}$

Ami a rendőrségi kommunikációt illeti az üggyel kapcsolatban, az első, 2009. február 23-án reggel kiadott közleményben az szerepelt, hogy Tatárszentgyörgyön az elsődleges tüzvizsgálói vélemény szerint elektromos zárlat okozta a tüzet, melyben ketten életüket vesztették. A boncolás eredményének ismeretében délután már az állt közleményükben, hogy az áldozatokra feltehetően vadászfegyverrel lőttek rá, miközben égő családi házukból menekültek. Pár nappal később már arról szóltak a tudósítások, hogy a Dabasi Rendőrkapitányság munkatársai hibát követtek el az ügyben, és emiatt fegyelmi eljárás

\footnotetext{
${ }^{636}$ Lásd uo. Tủzoltók, mentősök, ügyeletes orvos eljárásának értékelése 69.

${ }^{637}$ TV2 Tények éjszaka 2009. 02. 24.

${ }^{638}$ Lásd ERRC-NEKI-TASZ 2009. 69-70.
} 
is indult. A fegyelmi vizsgálatok elrendeléséről tájékoztatták a nyilvánosságot, azonban azok tényleges eredményéröl nem. ${ }^{639}$

Az Országgyülés Nemzetbiztonsági Bizottságának ténymegállapító vizsgálata a romák elleni támadássorozattal kapcsolatban jelentős szakmai hibákat és hiányosságokat tárt fel, így nem csupán a helyszíni munka, de a háttérben végzett megfigyelési tevékenység során ejtett hibák is felszínre kerültek. A vizsgálat megállapította, hogy az ügyben előzetes letartóztatásba került - és a jelentés elkészítését követően első- és másodfokon elítélt - szélsőséges nézeteket valló személyek, a „Magyar Köztársaság alkotmányos rendjének törvénytelen eszközökkel történö megzavarására irányuló magatartásuk miatt a Nemzetbiztonsági Hivatal látókörében voltak" ${ }^{640}$ A vizsgálat többek között szakmai hibaként állapította meg, hogy a „Nemzetbiztonsági Hivatal nyilvántartási rendszerében az ügyre vonatkozóan keletkezett információk, a különbözö vezetési szinteken nem kerültek egyeztetésre, elmaradt az érdemi értékelö, elemzö, és felülvizsgálati munkafázis, emiatt a Hivatal rutinszerüen végzett információgyüjtő tevékenysége konkrét érdemi eredményekben nem tudott megnyilvánulni". ${ }^{641}$ A rendszerszinten elmaradt szakmai és jogi segítségnyújtás következményeként nem került mélységében felderítésre az ellenőrzés alatt tartott személyi kör fegyverbeszerzésre vonatkozó törekvése, és a büncselekmények elkövetése szempontjából kritikus időszakban végzett további tevékenységének feltárása sem. A vizsgálat elsődleges célja annak megállapítása volt, hogy a nemzetbiztonsági szolgálatok munkája, a társszervek együttmüködése a rendőrséggel, illetve a Nemzeti Nyomozó Iroda munkatársaival mennyiben segítette a nyomozás hatékonyságát, eredményességét a romagyilkosságok elkövetőinek felderítése során. Emellett célja, hogy tisztázza azt, hogy az eljárásért felelős személyek a tőlük elvárható szakmai gondossággal jártak-e el a nyomozást segítő feladataik, tevékenységük során. Ebből kifolyólag a vizsgálat feladata az elkövetett hibák, mulasztások, valamint a lehetséges tanulságok számbavétele volt (de nem a személyre lebontott felelősség megállapítása), illetve javaslatok megfogalmazása annak érdekében, hogy hasonló hibák és mulasztások a jövőben elkerülhetővé váljanak. A szakmai hibák közé sorolható például az is, hogy a rendőrség sokáig elszigetelt jelenségként, nem pedig etnikai indíttatású támadássorozatként kezelte az eseteket.

\footnotetext{
${ }^{639}$ Lásd uo. A rendőrségi kommunikáció értékelése 70.

${ }^{640}$ Lásd Ténymegállapító vizsgálati jelentés 2009.

${ }^{641}$ Lásd uo.
} 
A romák ellen irányuló rasszista indíttatású támadások ügyében folytatott nyomozás 2009 augusztusában érkezett egy nagyobb állomáshoz, amikor is a Nemzeti Nyomozó Iroda augusztus 21-én hajnalban a terrorelhárító szolgálat segítségével Debrecenben elfogott öt embert, akik a gyanú szerint a romák elleni támadások elkövetői. Négyet még péntek délután őrizetbe is vett a rendőrség. ${ }^{642}$ A gyanúsítottakat a Budakörnyéki Bíróság két nappal később előzetes letartóztatásba helyezte. ${ }^{643}$

Végül a büntetőper 2011. március 25-én indult meg és több mint két évvel később azonban az ügy körülményeihez mérten nem meglepő módon, de az szokásosnál hosszabb és részletesebb bizonyítási eljárást követően - 2013. augusztus 6-án született meg az elsőfokú ítélet. A Budapest Környéki Törvényszék első fokon a cigányok ellen elkövetett, hat halálos áldozattal járó gyilkosságsorozat ügyében három vádlottat tényleges életfogytig tartó szabadságvesztésre ítélt, és tíz évre eltiltottak a közügyektöl, míg a negyedrendủ vádlottra nézve 13 év fegyházbüntetést szabtak ki. ${ }^{644}$

Az első és másodfokú eljárás között az ügy azzal is a sajtófigyelem középpontjába került, hogy az elsőfokú ítélet megszületése után a per tanácsvezető bírája ellen fegyelmi eljárást indítottak, mert a hatvannapos határidőt elmulasztva, tizenegy hónap alatt sem foglalta írásba - a később részletes jogi indoklással mintegy 880 oldalt kitevő - ítéletet. ${ }^{645} \mathrm{~A}$ Fővárosi Ítélőtábla 2015. május 8-án másodfokon helybenhagyta az első fokon kiszabott három tényleges életfogytiglani szabadságvesztés büntetést és a negyedrendủ vádlott 13 évnyi fegyházbüntetését. A három tényleges életfogytiglanra ítélt vádlott ügyében fellebbezések miatt harmadfokon a Kúrián folytatódik a büntetőper. ${ }^{646}$

Amint az említett kutatások mutatják, Magyarországon az elmúlt két évtizedben a gyülölet-büncselekmények áldozatává leggyakrabban váló romákkal szemben egyre

${ }^{642}$ Index: Elfogták a romák elleni támadások gyanúsítottjait. 2009. http://index.hu/bulvar/2009/08/21/elfogtak_a_romak_elleni_tamadasok_gyanusitottjait/ (2015.július 27.) ${ }^{643}$ Vas Népe Online: Elözetesben a romagyilkosságok gyanúsitottjai - Tagadják a büncselekmény elkövetését. 2009. http://vaol.hu/cimlapon/elozetesben-a-romagyilkossagok-gyanusitottjai-tagadjak-abuncselekmenyek-elkoveteset-fotoval-1446317 (2015. július 28.)

${ }^{644}$ Lásd Origo: Életük végéig tartó börtönre itélték a cigánygyilkosokat. 2013. http://www.origo.hu/itthon/20130805-iteletet-hoznak-a-romagyilkossagok-ugyeben.html (2015. július 29.)

645 Népszabadság Online: Fegyelmi a romagyilkosok perének bírája ellen. 2014. http://nol.hu/belfold/fegyelmi-miszori-biro-ellen-1473095 (2015. július 29.)

${ }_{646}$ Népszava Online: Romagyilkosságok: a Kúrián folytatódik a per. 2015. http://nepszava.hu/cikk/1056594-romagyilkossagok-a-kurian-folytatodik-a-per (2015. július 29.) 
erősödő előítéletesség figyelhető meg. Ezzel párhuzamosan pedig egyre több előítéletvezérelte büncselekmény kerül a hatóságok, a média és a civilszervezetek látókörébe. Mindezek fényében továbbra is kérdés, hogy az elöítéletek növekedésével párhuzamosan valóban növekszik-e az elkövetett gyülölet-büncselekmények száma is, vagy csupán a fogalom ismertebbé válásnak eredményeként kerül több eset a felszínre. Ugyanakkor az is kérdés, hogy ezzel párhuzamosan megkapják-e ezek az esetek a társadalomtól a jelenségnek „kijáró” figyelmet. Kérdés az is, hogy a tárgyalóteremben gyakran elmarasztalt rendőrség és az egyéb hatóságok tanultak-e valamit, illetve maga a társadalom tanult-e valamit a „magyar kriminalisztika eddigi legsúlyosabb büncselekmény sorozatából" ${ }^{647}$ Setét Jenő roma aktivista álláspontja szerint ${ }^{648}$ a roma közösségek egyértelmüen nem tudják túltenni magukat a történeteken és nem is szeretnék, éppen ezért civil csoportok minden évben megemlékezéseket tartanak. Azonban a társadalom egésze, illetve a többség nem érzi érintettnek magát.

Ezt támasztja alá vagy éppen ezt a hatást erősítették a médiareakcióik is. A médiahatóság összevetette Marian Cozma meggyilkolásával és a tatárszentgyörgyi kettősgyilkossággal kapcsolatos híradásokat és arra a megállapításra jutott, hogy „a tatárszentgyörgyi kettös gyilkosság esetében feltünően kevés gyászreakcióról tudósítottak a vizsgált híradók, holott elméletileg a gyermekgyilkosságoknál ilyenek természetesek és gyakoriak. Tipikusak voltak az áldozatok bemutatása közötti konceptuális különbségek: míg a nem roma áldozatot társadalmi státusza, foglalkozása alapján ismerhettük meg, a roma áldozatok individuális szerepmegjelölés nélkül, kizárólag etnikai hovatartozásuk alapján lettek bemutatva. Ez a fajta különbségtétel problémás, mivel ezáltal a kisebbséghez tartozó szereplö fö »tulajdonságát«, mintegy esszenciáját nem az egyénisége, hanem az etnikai csoporttagsága határozza meg. Az elhunyt és a gyászolók egy része is ismert sportoló, közéleti szereplö volt. A csoportképzés a befogadóban a »mi-ök« csoportközi kategóriáinak felállitásához és a másik csoport homogenizációjához vezethet, ami a kisebbségekkel szembeni elöitéletesség kialakulásának egyik feltétele."

647 Ténymegállapító vizsgálati jelentés... 2009.

${ }^{648}$ Elhangzott az RTL Magyarul Baló című müsorában a Romagyilkosságok: társadalmi tanulságok címü, Setét Jenővel és Zolnay Jánossal folytatott, beszélgetés keretében. 2015. április 14. http://rtl.hu/rtl2/magyarul/romagyilkossagok-tarsadalmi-tanulsagok (2015. augusztus 2.) 
Tehát még a híradásokban is elmaradt a várt gyászreakció, az esetek nem váltottak ki különösebb együttérzést, illetve nem eredményeztek olyan közös társadalmi fellépést, amely ezekkel az eszmékkel és magatartásokkal szállt volna szembe. Setét Jenő roma aktivista szerint durva üzenetértékü jelzés az is, hogy született egy dokumentumfilm Ítélet Magyarországon címmel, ${ }^{649}$ amelyet a készítő a köztelevízió elnökének figyelmébe ajánlott, ám válaszul elutasítást kapott. Annak ellenére, hogy - amint azt egy a film kapcsán született kritika is megfogalmazza ${ }^{650}$ a film és maga az eset alkalmas lehetne (alkalmasnak kellene lennie) arra, amire Gideon Hausner, Izrael állam föügyésze Ítélet Jeruzsálemben címü könyve és maga Eichmann-per: hogy változást hozzon, érdeklődést váltson ki, és felhívja a figyelmet arra, hogy a közösség elleni erőszak megtörténhetett, megtörtént, és köztünk élő emberek követték el, nem parancsra, hanem meggyőződésből. Hajdú Eszter filmje alkalmas lenne erre: „ha levetítik minden iskolában, minden magyar településen, minden moziban, müvelödési házban, közhivatalban legalább egyszer." ${ }^{651}$ Ez azonban eddig elmaradt, ahogy a társadalmi katarzis sem következett be, és csupán minimális kormányzati reflexió, illetve jogalkotási expanzió sem történt.

Ezzel kapcsolatban említhető meg, hogy az Egyesült Államokban ugyanazon évben, 1998-ban, két súlyos gyülölet-büncselekmény is történt. 1998 júniusában három fehér férfi felvette autójával az afroamerikai áldozatot, James Byrd Jr.-t, de ahelyett, hogy hazavitték volna, a város melletti félreeső útra vitték, ahol súlyosan bántalmazták, megalázták, majd az autóhoz láncolva mintegy 1,5 mérfölden keresztül húzták az aszfalton. Ugyanezen év októberében, Matthew Shepardot, egy fiatal meleg férfit kerítéshez láncoltak és megkínoztak. Matthew Shepard néhány nappal később belehalt fejsérüléseibe. Annak ellenére, hogy mindkét esetben megállapítást nyert az elöítéletmotiváció, az elkövetőkre nem gyülölet-büncselekmény miatt szabtak ki büntetést, mivel akkoriban egyik érintett államnak sem volt gyülölet-büncselekmény tényállása. ${ }^{652}$ Shephard halálhírének hatására az Egyesült Államokban és világszerte megmozdulások kezdődtek a gyülölet-büncselekmények ellen. ${ }^{653}$ Az LMBT közösségnek (és Shephard

\footnotetext{
649 Origo: Ilyen országban élünk. 2014. http://www.origo.hu/filmklub/blog/kritika/20140520-ilyenorszagban-elunk-itelet-magyarorszagon-kritika-hajdu-eszter-romagyilkossagok.html (2015. augusztus 1.) ${ }^{650}$ Lásd uo.

${ }^{651}$ Lásd uo.

652 Daniel Aisaka - Rachel Clune (szerk.): „Hate Crime Regulation and Challenges”The Georgetown Journal of Gender and the Law, 2013/2. 472.

${ }^{653}$ Lásd pl. Matthew Shepard Foundation. http://www.matthewshepard.org/
} 
szüleinek) mintegy tíz évébe telt, de 2009. október 28-án Barack Obama aláírta a Matthew Shepard and James Byrd Jr. Hate Crimes Prevention Actet, amely a szövetségi szintű gyülölet-büncselekmények elleni szabályozásba beemelte védett csoportként a szexuális irányultságot és a nemi identitást is. ${ }^{654} \mathrm{Az}$ Egyesült Államok egyik legnagyobb civil szervezete egy rövid listát készített ${ }^{655}$ arról, hogy milyen erőfeszítések rejlenek a törvény elfogadás mögött, így többek között: több mint egymillió email/fax/telefonhívás a Capitoliumba a törvényjavaslatot támogatóktól; a támogatását írásban kifejező több mint háromszáz aláíró szervezet (civilek, rendőrségi szervezetek stb.); egy elnök, aki támogatta az ez irányú jogalkotást; egy elnök, aki a prevenció érdekében tett meg mindent; valamint egy elnök, aki végül aláírta a jogszabályt. Ez a nem teljes - lista jól szemlélteti a különböző „,szinteket”: a lakosság, civil szervezetek, média, közszféra és politikai akarat együttesen járult hozzá ahhoz, hogy ma már szövetségi szinten van gyülölet-büncselekményekre vonatkozó szabályozás és adatgyüjtési szabályok. Magyarországon 2012 óta a GYEM egyszerre próbál együttműködni és nyomást gyakorolni; és történtek is előrelépések a gyülöletbűncselekmények szabályozása és üldözése területén. A magyar jogalkotás és jogalkalmazás alapvetően progresszív irányt vett az elmúlt években, de rengeteg még a tennivaló.

A tatárszentgyörgyi eset és a sorozatgyilkosságok egy szempillantás alatt váltak a teljes magyar társadalom ,állatorvosi lovává”. A hatósági hibák, mulasztások és kötelességszegések, a teljes jogi eljárás kálváriája, a magyar társadalom reakciói (vagy éppen annak hiánya vagy csökkentett formája), a kormányzati és politikai válaszlépések mind a magyar helyzet, a romák magyarországi marginalizációjának, szegregációjának, kitaszítottságának lenyomatai. A kutatások alapján azonban úgy tünik, hogy egy ilyen súlyú eset sem rázta meg annyira a társadalmat, hogy „kizökkenjen” az egyre mélyülő és erősödő elöítéletek spiráljából. Kállai Ernő is rámutatott arra, hogy a társadalom a támadássorozat után sem nézett szembe azzal, hogy a gyülölködés, kirekesztés fenntartása milyen tragikus következménnyel járhat és ezt a folyamatot kizárólag közös erővel lehet megállítani. ${ }^{656}$

\footnotetext{
${ }^{654}$ Jessica Malloy-Thorpe - David Hemken (szerk.): „Hate Crime Regulation and Challenges”The Georgetown Journal of Gender and the Law, 2012/2. 291.

${ }^{655}$ Lásd Human Rights Campaign. http://www.hrc.org/resources/entry/hate-crimes-law (2015. augusztus 2.)

${ }^{656}$ Kállai Ernő: Megszüntetve a kisebbségi ombudsman összegzése. Budapest, 2011. 54.
} 
Visszautalva az Országos Kriminológiai Intézet 2009-es állásfoglalására fontos rámutatni ismételten, hogy ha ezt a jelenséget nem hatástalanítják időben, azaz nem törekszenek a jelenség mögötti valós problémák rendezésére vagy enyhítésére, az beláthatatlan következményekkel járhat. A gyülölet-büncselekményekkel kapcsolatos tapasztalatok ugyanis azt mutatják, hogy az aggodalom és a félelem adott esetben kiválthatja a megtámadott csoportban a megtorlás iránti vágyat, végső soron társadalmi csoportok közötti feszültséghez, agresszióhoz vagy akár összecsapásokhoz vezethet. A tragédiák megelőzéséhez vezető, felelős büntetőpolitikára és a valós helyzetet feltáró kutatások (pl. áldozatkutatások) eredményeinek elemzésén nyugvó, hatékony beavatkozásokra ugyanúgy szükség lenne, mint 2009-ben. ${ }^{657}$

\section{Adatgyüjtés}

A gyülölet-büncselekmények elterjedtségére és hatósági kezelésére vonatkozó megbízható adatok összegyüjtése, elemzése és nyilvánosságra hozatala alapvető jelentőségü mind a széles társadalom, mind az érintett hatóságok tudatformálásához. A megbízható adatgyüjtési rendszer elősegíti a probléma teljes megértését és a hatékony fellépést. A megbízható adatok kulcsfontosságúak a gyülölet-büncselekményekkel kapcsolatos szakpolitikák fejlesztéséhez, és segítik a lobbitevékenységet végző és áldozatok segítésével foglalkozó szervezetek munkáját. ${ }^{658}$

Az adatgyüjtés, sajnos, igencsak kezdetleges, ami az elöítélet-vezérelte büncselekményeket illeti, illetve rendszintü problémák is tapasztalhatók. Az elmúlt évek statisztikáit tekintve nagyon csekély arányban jelennek meg gyülölet-büncselekmények. A gyülölet-büncselekményekre vonatkozóan állami szerveknél célzott adatgyüjtés nem folyik. A hatóságok tudomására jutott büncselekményekkel kapcsolatos adatokat az egységes nyomozó hatósági és ügyészségi bünügyi statisztikai rendszer (ENyÜBS) tartalmazza, amelynek alapját a 12/2011. (III.30) BM rendelet képezi. A vádemelésre és a bírósági eljárásra vonatkozó adatok a Vádképviseleti Informatikai Rendszer (VIR), ${ }^{659}$ illetve a bírósági statisztikai rendszerben követhetők nyomon. Azonban a rendszerek eltérő időpontokban, az eljárás különböző szakaszaiban gyüjtenek adatokat. Az

${ }^{657}$ Lásd OKRI Állásfoglalás 2009.

${ }^{658}$ CEJI - Zsidó Hozzájárulás a Befogadó Európához (A Jewish Contribution to an Inclusive Europe): Tegyünk láthatóvá a gyülölet-büncselekményeket. Nézzünk szembe a tényekkel! Útmutató a gyülöletbüncselekmények és elöitélet motiválta incidensek monitorozásához. 2012. november. http://www.ceji.org/media/facing-facts-guidelines-hungarian.pdf (2014. június 7.)

${ }^{659}$ Bevezetéséröl a 16/2007. (ÜK. 12.) LÜ utasítás rendelkezett. 
ENyÜBS adatgyüjtése a nyomozás befejezésekor zárul le, míg a VIR adatgyűjtése a vádemeléskor kezdődik, és a jogerős ítélet megszületésekor zárul le. A rendszerek a büntetőeljárás különböző szakaszait vizsgálják, eltérő adatbázissal dolgoznak, így az adatok sajnos nem összekapcsolhatók.

Az ENYÜBS a regisztrált bűncselekményeket tartalmazza a hatóságok jogi minősítése alapján. A rendszer egyik alapvető problémája éppen abból fakad, hogy a büncselekmények besorolása a hatóságok minősítésén múlik. Így hiába érzékeli a sértett vagy más a gyülölet-motívumot, ha hatóságok nem veszik figyelembe, nem jelenik meg a rendszerben, így az alulminősítések sem követhetők nyomon. ${ }^{660}$ Az adatgyüjtés alapját képező regisztrált büncselekmények körébe azon cselekmények tartoznak, amelyekről a büntetőügyben eljáró hatóságok (nyomozó hatóságok és ügyészség) a tárgyidőszakban meghozott: vádemelés; vádemelés részbeni mellőzése; büntetőeljárás átadása; közvetítői eljárást követő nyomozásmegszüntetés; közvetítői eljárást követő vádemelés elhalasztása; elterelés (vádemelés elhalasztása, kábítószerélvezővel szemben alkalmazott vádemelés elhalasztása); büntethetőségét kizáró vagy megszüntető ok miatt feljelentés elutasítás, illetőleg nyomozásmegszüntetés, ideértve a megrovás alkalmazását is; az elkövető ismeretlen volta miatt nyomozás-felfüggesztés ${ }^{661}$; a nyomozásmegszüntetés, mert nem a gyanúsított követte el a büncselekményt; nyomozásmegszüntetés, mert nem állapítható meg, hogy a gyanúsított követte el a büncselekményt; nyomozásmegszüntetés tevékeny megbánás miatt; nyomozás részbeni mellőzése; megállapodás; a legfőbb ügyész feljelentése külföldi államnál; fedett nyomozóval szemben alkalmazott feljelentés-elutasítás, illetőleg nyomozásmegszüntetés; feljelentés-elutasítás, illetőleg nyomozásmegszüntetés a Btk. 236. §-ban, illetőleg 240. §-ban meghatározott feltétel hiánya miatt; fegyelmi eljárásra utalás; büntetőeljárási döntésben megállapították, hogy büncselekmények. ${ }^{662} \mathrm{~A}$ rendszer a sértett nemét, életkorát, állampolgárságát és foglalkozását tartalmazza, egyéb személyes jellemzőket (így a gyülölet-büncselekmények szempontjából releváns

\footnotetext{
${ }^{660}$ Dombos Tamás-Udvari Márton: Gyülölet-büncselekmények Magyarországon. Problémák, javaslatok, jó gyakorlatok. 2014. 16. http://helsinki.hu/wp-content/uploads/tanulmany.pdf (2015. március 26.)

661 2006. július 1. és 2009. augusztus 12. között a nyomozás megszüntetésének volt helye, ha az elkövető kiléte a nyomozás során nem volt megállapítható. A 2003. július 1. és 2006. június 30. közötti időszakban, illetőleg 2009. augusztus 13. óta e jogcímen a nyomozás felfüggesztésére kerül sor.

${ }^{662}$ Belügyminisztérium Koordinációs és Statisztikai Osztály, Legföbb Ügyészség Informatikai Főosztály: Tájékoztató a 2012. évi bünözésröl.
} 
társadalmi csoporthoz tartozást) nem. ${ }^{663}$

Az ENyÜBS adatlapokat kódszótárak alapján töltik ki. Az elöítélet motívumra vonatkozóan korlátozott információkat gyüjtenek az elkövetés módszerei körében. Ezek a kódok sokszor nem kötődnek a Btk.-hoz, és van, ahol sokkal bővebbek a kódszavak. Az EBESZ útmutatóiban is azt tanácsolja, hogy a Btk.-hoz kötődő fogalmakra építve végezzék az adatgyüjtést, mert így biztosított igazán a hatékonyság. ${ }^{664}$ Az közösség tagja elleni erőszak esetében az elkövetés módszereinél az ENYÜBS kódszótárban ${ }^{665} 16$ kategória szerepel, amelyek fele köthető a motivációhoz. Ezek az alábbiak: etnikai csoporthoz való vélt vagy valós tartozás; faji csoporthoz való vélt vagy valós tartozás; lakossági csoporthoz való vélt vagy valós tartozás; vallási csoporthoz való vélt vagy valós tartozás; egyébre tekintettel; fogyatékosságra tekintettel; nemi identitásra tekintettel; szexuális irányultságra tekintettel. Ugyanezen kategóriákkal dolgozik a statisztikai rendszer a közösség elleni uszítás esetében is. Ezen kívül a népirtás (Btk. 142. §), emberölés (Btk. 160. §), erős felindulásban elkövetett emberölés (Btk. 161. §), testi sértés (164. §) és kapcsolati erőszak (Btk. 212/A. §) büncselekménye esetében az aljas indokon belül a „rasszizmus, faji elöitélet” zavaros alkategóriája szerepel a kódszótárban. Ezzel kapcsolatban egyrészt nem világos, hogy miért pont e tényállásoknál szerepel ez a kategória, hiszen más büncselekmények kapcsán is felmerülhet ugyanekkora valószínűséggel az elöítélet motiváció (például zaklatás). Másrészt a „rasszizmus, faji elöitélet” a védett csoportok szük körét fedi le. A vallási csoporthoz tartozás, szexuális irányultság, nemi identitás és fogyatékosság miatti elkövetés esetén ez a kategória semmiképp nem használható. Végül a kategória több védett csoportot is magában foglal, viszont azok részletezésére nincs lehetőség. Így az a helyzet áll elő, hogy a közösség tagja elleni erőszak esetében részletesebb adatok állnak rendelkezésre, mint egy súlyosabban minősülő emberölés büncselekménye esetén. ${ }^{666}$

A kategóriákkal kapcsolatban még az is problematikus, hogy pontosan milyen esetkört is fednek le, mert a kódszótár semmilyen fogalom meghatározást nem ad a fenti kategóriákra. Azok a Btk.-ban sem szerepelnek, így a jogszabály sem ad semmilyen útmutatást. Mint látható, alapvető jogalkalmazási és jogértelmezési problémák

\footnotetext{
${ }^{663}$ Dombos-Udvari 2014, 16.

${ }^{664}$ Lásd EBESZ/DIEJH: Hate Crime Data-Collection... 2014.

${ }^{665}$ GYEM közérdekủ adatigénylése keretében megkapott kódszótárak. Kódszótár elkövetés módszerére.

${ }^{666}$ Lásd Dombos-Udvari 2014, 16.
} 
merülnek fel a gyülöletvezérelte büncselekményekkel kapcsolatban, így vélelmezhető, hogy a statisztikai fogalmak alkalmazása legalább akkora kihívást jelent a rendőrség számára, mint a Btk.-ban szereplő fogalmak használata. Az is bizonytalan e tekintetben, hogy a rendőrség tagjai milyen képzést vagy egyáltalán kapnak-e képzést az ENyÜBS használatával kapcsolatban. Tehát lényegében sem az ENyÜBS, sem a VIR nem gyüjt adatokat arra nézve, hogy a büncselekmények mely védett tulajdonságok ellen irányultak, amint erre a Legfőbb Ügyészség is rámutatott közérdekü adatigénylésre írt válaszában. ${ }^{667}$

Mint említettem, az elmúlt évek adatait tekintve az előítélet-vezérelte bűncselekmények rendkívül alacsony arányban jelennek meg a hivatalos statisztikákban. A 2010 és 2012 közötti ENyÜBS adatok alapján a rendőrség által regisztrált közösség tagja elleni erőszak bűncselekményére vonatkozó adatok az alábbiak: 668

\begin{tabular}{|c|c|c|c|}
\hline \multicolumn{4}{|c|}{ Regisztrált bűncselekmények - 1978. évi Btk. 174/B. § alapján (ENyÜBS) ${ }^{669}$} \\
\hline & 2010 & 2011 & 2012 \\
\hline Nyomozáskezdeményezések száma & 24 & 40 & 46 \\
\hline Regisztrált büncselekmények & 18 & 34 & 36 \\
\hline $\begin{array}{l}\text { Regisztrált büncselekmények elkövetés módszere szerint (etnikai, } \\
\text { faji, lakossági, nemzeti, vallási csoporthoz való vélt vagy valós } \\
\text { tartozás miatt) }^{670}\end{array}$ & 7 & 19 & 15 \\
\hline $\begin{array}{l}\text { Regisztrált büncselekmények, ahol az elkövetés módszere lakossági } \\
\text { csoporthoz való vélt vagy valós tartozás }\end{array}$ & 0 & 2 & 0 \\
\hline
\end{tabular}

Az adatokból az látszik, hogy a közösség tagja elleni erőszak esetében nem bontják le az adatokat a fenti alkategóriák szerint. A kapott táblázatok „ömlesztve” tartalmazzák az adatokat az egyes alkategóriákra vonatkozóan. Közösség tagja elleni erőszak esetében a regisztrált büncselekményeket egybefoglalva tartalmazza a táblázat öt kategória alapján

${ }^{667}$ GYEM közérdekủ adatigénylésére válaszlevél. Legföbb Ügyészség, Ig. 106/31/2014. Legf. Ü. szám. ${ }^{668}$ ORFK: 2011-2013-as időszakra vonatkozó jelentés, 29000/8268-5/2014/Ált.

669 A táblázat még a korábbi (2010-es) kódszótár alapján tartalmazza az adatokat, amikor a fogyatékosságra, nemi identitásra és szexuális irányultságra tekintettel még nem gyüjtötték az adatokat.

${ }^{670}$ Fogyatékosságra, nemi identitásra és szexuális irányultságra tekintettel azért nem szerepelnek adatok, mert ezen védett csoportok az 1978. évi Btk.-ban még nem szerepeltek külön megnevezve. 
(etnikai csoporthoz való vélt vagy valós tartozás; faji csoporthoz való vélt vagy valós tartozás; lakossági csoporthoz való vélt vagy valós tartozás; vallási csoporthoz való vélt vagy valós tartozás). Emellett nem egyértelmü, hogy az összesített regisztrált büncselekmények száma miért nem egyezik az alkategóriákra lebontottak adatokkal, kiváltképp, ha a felsorolás taxatív és minden kódszótárbeli kategóriát tartalmazza a táblázat. Egy lehetséges indoka a fenti különbségnek az lehet, hogy a statisztikai adatlapok kitöltésekor csupán a büncselekményt jelölték meg, de az elkövetés módszerét nem. Emellett a táblázat a nyomozáskezdeményezések számára is tartalmaz adatokat, amelyeket az ENYÜBS nem tartalmaz, hanem a rendőrség belső rendszeréből (Robotzsaru) ${ }^{671}$ nyerhetők ki adatok erre nézve.

A 2013-as évre vonatkozóan az 1978. évi Btk. vonatkozásában éves, míg az új Btk. alapján VII-XI. havi adatok állnak rendelkezésre. ${ }^{672}$

\begin{tabular}{|r|r|}
\hline $\begin{array}{l}\text { Regisztrált büncselekmények - 1978. } \\
\text { évi Btk. 174/B. § alapján (ENyÜBS) }\end{array}$ & $\begin{array}{c}\text { Regisztrált büncselekmények 2013. VII- } \\
\text { XII. hó - Btk. 216. § alapján (ENyÜBS) }\end{array}$ \\
\hline 36 & 6 \\
\hline
\end{tabular}

A VIR és a bírósági statisztika még az ENYÜBS rendszernél és korlátozottabb körben gyüjt adatokat. Ezért nincs is lehetőség a közösség tagja elleni erőszak büncselekménye esetében a védett csoportok szerint lebontásban gyüjteni adatokat. Más esetekben pedig az aljas indokból elkövetéstől nem lehet elválasztani az előítélet motivációt, illetve bizonyos esetekben az alapesettől sem. ${ }^{673}$ A vádemelések tekintetében 2012-ig állnak rendelkezésre adatok, mivel a 2014 februárjában - a közérdekü adatigénylés időpontjában - az ENyÜBS 2013. évi adatainak ellenőrzése és a végleges adatbázis összeállítása még folyamatban volt az ügyészségen. ${ }^{674}$

\section{A regisztrált büncselekményekből a közösség tagja elleni erőszak vádemelési adatai, 2010-2012}

\footnotetext{
671 Robotzsaru integrált ügyviteli, ügyfeldolgozó és elektronikus iratkezelő rendszer. Bővebben lásd a Robotzsaru integrált ügyviteli, ügyfeldolgozó és elektronikus iratkezelő rendszer egységes és kötelező használatáról, jogosultsági rendjéről, az adatvédelem, valamint a rendszerfejlesztés előírásairól szóló 18/2011. (IX. 23.) ORFK utasítás.

${ }^{672}$ ORFK: 2011-2013-as időszakra vonatkozó jelentés. 29000/8268-5/2014/Ált.

${ }^{673}$ Dombos-Udvari 2014, 17.

${ }^{674}$ Legföbb Ügyészség válaszlevél. Ig. 106/31/2014. Legf. Ü. szám.
} 


\begin{tabular}{|l|r|r|rr|}
\hline \multicolumn{1}{|c|}{$\mathbf{2 0 1 0}$} & \multicolumn{1}{c|}{$\mathbf{2 0 1 1}$} & $\mathbf{2 0 1 2}$ & \\
\hline 1978. évi Btk. 174/B. $\$$ & 12 & 28 & & 16 \\
\hline
\end{tabular}

A bírósági döntések számát a VIR tartja nyilván. Az alábbi táblázat azoknak az ügyeknek, illetve vádlottaknak a számát tartalmazza, akikkel szemben a bíróság az adott évben hozott jogerős döntést: ${ }^{675}$

\begin{tabular}{|l|r|rr|}
\hline \multicolumn{2}{|l|}{ Közösség tagja elleni erőszak az 1978. évi Btk. 174/B. \$-a és a Btk. 216. \$-a alapján } \\
\hline \multicolumn{2}{|c|}{ Évek } & Ügyek & \multicolumn{2}{|c|}{ Elítéltek } \\
\hline 2010 & 5 & 11 \\
\hline 2011 & 8 & 15 \\
\hline 2012 & 12 & 23 \\
\hline 2013 & 14 & 34 \\
\hline
\end{tabular}

A jelenlegi rendszer szemmel láthatóan nem hatékony, és számos kérdés vetődik fel a müködésével kapcsolatban. Az adatgyüjtés pontos módszertanára, a rendszer használatával kapcsolatos képzésekre vonatkozóan információk nem állnak rendelkezésre, így az eltérés pontos okai ismeretlenek. Az egyik legnagyobb probléma pedig, hogy az adatbázisok teljesen függetlenek egymástól, így az abban szereplő ügyek nem is köthetőek egymáshoz. Így nem is lehet végigkövetni egy bűncselekmény sorsát a bejelentéstől a büntetés kiszabásáig. A bírósági statisztikai rendszerben ráadásul az eljárásokat csupán egyetlen Btk. tényállás alapján lehet besorolni. Ez a gyakorlatban azt jelenti, hogy több büncselekmény kapcsán indult eljárásokban csupán a legsúlyosabb büncselekmény fog megjelenni a statisztikában.

Az Európai Unió Alapjogi Ügynökségének - korábban említette - besorolása szerint is csak szük körben gyüjt adatokat Magyarország európai összehasonlításban. A három kategória (átfogó adatgyüjtés, jó színvonalú adatgyüjtés, korlátozott adatgyüjtés) közül Magyarország a harmadikba tartozik, azaz csak korlátozott esetszámra vonatkozó

${ }^{675}$ Lásd uo. 
statisztikával rendelkezik, és többnyire nem is publikálják ezen adatokat. ${ }^{676}$

Mindezekre tekintettel az adatok sokkal inkább a gyülölet-büncselekmények rendkívül magas magyarországi látenciáját, a gyakori alulminősítést, illetve az adatgyüjtés hiányosságait mutatják. Az Athena Intézet például 2009 januárja óta vezet adatbázist a nyilvánosságot kapott gyülölet-büncselekményekről. ${ }^{677}$ Az adatbázis természetesen nem tekinthető hivatalos forrásnak, de a 2009. január és 2012. december közötti időszakra vonatkozóan összesen 121 esetleírás szerepel, amely szám magasabb az ezen időszakra vonatkozó hivatalos statisztika által kimutatott eseteknél. Az eltérés abból is adódik, hogy az adatbázisban olyan esetek is szerepelnek, amelyekben nem indult hivatalos eljárás, illetve olyan eset is, amelyekben indult eljárás, de azt hivatalosan nem gyülöletbüncselekményként regisztrálták.

Szintén problémát jelent, hogy Magyarországon - más országokkal ellentétben ${ }^{678}$ - nem készül rendszeresen nagymintás reprezentatív adatfelvétel az áldozattá válásról. Az egyetlen elérhető adat az EU Bizottsága által finanszírozott, nemzetközi módszertant használó European Crime and Safety Survey (EU ICS) 2005-ből. ${ }^{679}$ A kutatás eredményei ${ }^{680}$ szerint Magyarországon a válaszadók vagy közvetlen környezetük tagjainak 1\%-a vált gyülölet-büncselekmény áldozatává 2001 és 2005 között. Összehasonlításképpen ugyanezen időszakban 3,3\% számolt be gépjármülopásról. A hivatalos statisztikák ${ }^{681}$ szerint ugyanezen időszakban 42.329 gépjármülopás és 42 nemzeti, etnikai, faji, vallási csoport tagja elleni erőszak vált ismertté. Mindezek alapján úgy becsülhető, hogy a gyülölet-büncselekmények mintegy 99,7\%-a nem kerül jelentésre, vagy a hatóságok azt nem minősítik gyülölet-büncselekménynek. ${ }^{62}$ Ugyanezt támasztja alá az MTA Szociológiai Kutatóintézet és Háttér Társaság a

${ }^{676}$ FRA: Making hate crime visible... 2012, 36.

${ }^{677}$ Lásd http://athenaintezet.hu/gyuloletbuncselekmeny_lista (2013. november 30.)

678 A Crime Survey for England and Wales 1982 óta folytatott, bünözéssel kapcsolatos felmérés, amely Angliára és Walesre terjed ki, és amelynek során arról kérdezik a lakosság tagjait, hogy az elmúlt egy évben büncselekmény áldozataivá váltak-e; az egyes büncselekménytípusok elterjedtségének és vizsgálata érdekében.

${ }^{679}$ Jan van Dijk [et al.] 2005.

${ }^{680}$ GYEM saját elemzése a Gallup Magyarország által rendelkezésre bocsátott adatbázis alapján. Lásd GYEM Az új Büntetö törvénykönyv gyülölet-büncselekményekre vonatkozó rendelkezéseinek kialakitása során figyelembe veendö szempontok 2012.

${ }^{681}$ Lásd http://www.police.hu/data/cms2118/bcs_k_1996_2005.pdf (2012. február 22.)

682 GYE: Az új Büntetö törvénykönyv gyülölet-büncselekményekre vonatkozó rendelkezéseinek kialakitása során figyelembe veendö szempontok 2012, 4. 
Melegekért 2010-es adatfelvétele, ${ }^{683}$ amely a magyarországi leszbikus, meleg, biszexuális és transznemü embereket célozta. Az 1674 válaszadó közül 15,6\%-ot ért már élete során, 4,4\%-ukat az elmúlt 12 hónapban szexuális irányultságával vagy nemi identitásával összefüggésben erőszakos büncselekmény. A transznemüekkel az erőszakos támadások száma még ennél is magasabb, 26,2\%-ukat élete során, 11,7\%ukat az elmúlt 12 hónapban érte erőszakos támadás. A kutatásból az is kiderül, hogy az áldozatok csupán 13,4\%-a jelentette az esetet a rendőrségnek. Eszerint a homofób és transzfób indíttatású gyülölet-büncselekmények sokkal elterjedtebbek, mint azt a hivatalos statisztikák mutatják. ${ }^{684}$ Emellett az Országos Kriminológiai Intézet (OKRI) 1996-ban, 2000-ben és 2003-ban ugyan folytatott áldozatkutatásokat, azonban ezek nem tértek ki a gyülölet-büncselekmények témájára. ${ }^{65}$

A rendszer hatékonyabbá tétele érdekében alapvető fontosságú lenne a statisztikák kapcsán, hogy teljes körü adatgyüjtést végezzenek, azaz ne csupán a közösség tagja elleni erőszak, de más gyülöletvezérelte büncselekmények esetében is pontos adatok álljanak rendelkezésre (emberölés, testi sértés). Ami többféleképpen is történhetne: akár a gyülölet-büncselekmények statisztikai fogalmának bevezetésével; vagy akár a Btk. tényállásaihoz ragaszkodva, a jelenlegi rendszert kiegészítve az elöítéletes indíték általános kategóriának bevezetésével, de szükségszerűen rendszeresítve a gyülöletbüncselekményekkel leggyakrabban kapcsolatba hozható tényállásokra (a jelenlegi rendszerben gyüjtött büncselekmények mellett a rongálás, zaklatás, személyi szabadság megsértése, rágalmazásra, jogellenes fogvatartás, alárendelt megsértése, szexuális erőszak és szexuális kényszerítés büncselekményeire vonatkozóan is $\left.{ }^{686}\right)$. Indokolt még az adatgyüjtést valamennyi áldozati csoportra lebontva végezni, valamint az adatgyüjtési rendszerek egységes ügyszámokkal összekapcsolhatóvá tétele is fontos, ezáltal biztosítva az ügyek teljes nyomon követhetőségét a nyomozás megindulástól a bírósági eljárás lezárultáig. Szintén nagyon fontos ezen adatok teljes nyilvánossága, ugyanis a jelenlegi rendszerben csak tényállás szerinti bontásban van hozzáférés a

${ }^{683}$ Submission by Háttér Support Society for LGBT People in Hungary for the OSCE ODIHR 2010 annual report on hate crimes. http://www.hatter.hu/kiadvanyaink/osce-hatecrime-2010 (2013. december 2.)

684 GYEM: Az új Büntetö törvénykönyv gyülölet-büncselekményekre vonatkozó rendelkezéseinek kialakitása során figyelembe veendö szempontok 2012, 4.

685 Dombos-Udvari 2014, 17. illetve bövebben lásd OKRI: Áldozatkutatás http://www.okri.hu/content/view/191/165 (2015. március 26.)

${ }^{686}$ Dombos-Udvari 2014, 8. 
bünügyi statisztikai adatokhoz. ${ }^{687}$ Végül amint a FRA is javasolta az elöítélet-vezérelte büncselekményekre vonatkozó hivatalos adatgyüjtési mechanizmusokat ki kellene egészíteni a büncselekmények áldozatává válását vizsgáló felmérésekkel, hogy fény derüljön az olyan aspektusokra is, mint a nem bejelentett büncselekmények jellege és mértéke, az áldozatok tapasztalatai a bünüldöző szervekkel kapcsolatban, a bejelentés elmaradásának okai és a gyülölet-büncselekmények áldozatainak jogtudatossága. ${ }^{68}$

Magyarországnak nemzetközi kötelezettségei is vannak az adatgyüjtést illetően az Európai Parlament és a Tanács 2012/29/EU irányelve alapján. ${ }^{689}$ A 64. bekezdésben foglaltak szerint az irányelvben meghatározott jogok terén történő hatékony szakpolitikai döntéshozatalnak egyik alapvető eleme a rendszeres és megfelelő statisztikai adatgyüjtés. Ezért a tagállamoknak közölniük kell a Bizottsággal a büncselekmények áldozataira vonatkozó nemzeti eljárások alkalmazásával kapcsolatos releváns statisztikai adatokat, beleértve legalább a feljelentett büncselekmények számát és típusát, valamint amennyiben ezek az adatok ismertek és rendelkezésre állnak, az áldozatok számát, életkorát és nemét. Az irányelvben meghatározottak nemzeti jogba történő átültetésére a tagállamoknak legkésőbb 2015. november 16-ig kell intézkedni. Magyarország még nem léptette hatályba az irányelvvel összefüggésben a szükséges törvényi, rendeleti és közigazgatási rendelkezéseket, az általános rendőrségi feladatok ellátására létrehozott szervnek nincs az irányelv által megkövetelt eljárásrendje a specifikus védelmi szükségletekkel rendelkező áldozatok beazonosítására. ${ }^{690}$

\section{Jó gyakorlatok}

A gyülölet-büncselekményekkel szembeni fellépés terén elsősorban - a korábban már sokszor hivatkozott - GYEM említendő. 2012 januárjában jött létre a Gyülöletbüncselekmények Elleni Munkacsoport (GYEM). A munkacsoportot öt civil

\footnotetext{
${ }^{687}$ Illetve a kézirat lezárásának napjáig (2014. december 10.) még ezen adatokhoz sincs hozzáférés, mert a crimestat.b-m.hu oldal egy ideje nem elérhető. Jelen írás készítése idején az oldal nem müködött (2014. november-december). De az átlátszó.hu közérdekủ adatigénylése alapján úgy tünik, hogy az oldal már 2013 novemberében sem müködött. http://kimittud.atlatszo.hu/request/bm-statisztika-portal (2014. december 6.)

${ }^{688}$ Lásd FRA: Gyülölet-büncselekmények az Európai Unióban. 2012.

${ }^{689}$ Az Európai Parlament és Tanács 2012/29/EU irányelve (2012 október 25.) a bűncselekmények áldozatainak jogaira, támogatására és védelmére vonatkozó minimumszabályok megállapításáról és a 2001/220/IB tanácsi kerethatározat felváltásáról (Directive 2012/29/EU of the European Parliament and of the Council of 25 October 2012 establishing minimum standards on the rights, support and protection of victims of crime, and replacing Council Framework Decision 2001/220/JHA), HL L 315/57, 2012.11.14.

${ }^{690}$ ORFK: 2011-2013-as időszakra vonatkozó jelentés. 29000/8268-5/2014/Ált.
} 
szervezet ${ }^{691}$ hozta létre, a közös fellépés érdekében. A munkacsoport munkájában a jelenleg hat szervezet képviselöi mellett a területen jártas szakemberek is részt vesznek. ${ }^{692}$ A GYEM fő célkitüzése a gyülölet-büncselekmények visszaszorítása, amelyet az alábbi tevékenységekkel igyekszik megvalósítani: a gyülöletbüncselekmények elleni hatékonyabb állami fellépés jogszabályi és intézményi feltételeinek megteremtése; az áldozatok bátorítása a jogi eljárások indítására; a gyülölet-büncselekmények szemben elutasító társadalmi közeg kialakítása. A munkacsoport rendszeresen véleményez jogszabályokat, és tesz javaslatokat a hatósági fellépés megerősítése érdekében. Kutatások mellett képzések összeállításával és megtartásával is foglalkozik. ${ }^{693}$ A munkacsoport 2013-ban elkészítette a közösség tagja elleni erőszak tényállásának alternatív kommentárját, ${ }^{694}$ amelyben rámutatott, arra, hogy a jogalkotó a 2011-es módosítással ismerte el, hogy az egyes társadalmi csoportok elleni előítéletes fellépés esetén a büntetőjogi szankcionálással nem szabad megvárni, amíg a konfliktus nyílt erőszakká eszkalálódik; az alacsonyabb intenzitású, erőszakkal vagy kényszerítéssel nem járó magatartások esetén is indokolt a büntetőjogi üldözés. A jogalkotó ezért - lényegében a garázdaság szabálysértési tényállásának elöítéletes indítékkal való bővítése révén - a riadalom keltésére alkalmas kihívóan közösségellenes magatartást is e tényállás hatókörébe vonta, ha annak indítéka a sértett valamely társadalmi csoporthoz tartozása. A törvényjavaslat indokolása ${ }^{695}$ szerint a kihívóan közösségellenes magatartás tanúsításával megvalósítható büncselekmény esetén nem szükséges, hogy az elkövető az ilyen magatartást a csoport tagja ellen tanúsítsa, elegendő, ha az dolog ellen irányul. Lobbitevékenységével összhangban a Btk. nevesítetten is védi a szexuális irányultság, nemi identitás és fogyatékosság szerinti csoportokat a közösség tagja elleni eröszak (Btk. 216. §) és a közösség elleni uszítás (Btk. 332. §) tényállásai keretében, illetve továbbra is büntetendő a közösség tagja elleni erőszak előkészülete. Szintén a lobbitevékenységével összhangban 2013. július 1-jétől a közösség tagja elleni erőszak büncselekménye kapcsán indult nyomozásokat a megyei (fővárosi) rendőr-főkapitányságok kell, hogy végezzék. A munkacsoport 2013-ban

\footnotetext{
${ }^{691}$ Amnesty International Magyarország, Háttér Társaság, Magyar Helsinki Bizottság, Nemzeti és Etnikai Kisebbségi Jogvédő Iroda (NEKI), Társaság a Szabadságjogokért (TASZ)

${ }^{692}$ Demeter Áron, AI Magyarország; Dinók Henriett, MTA TK Jogtudományi Intézet; Dombos Tamás, Háttér Társaság; Jovánovics Eszter, TASZ; Ivány Borbála, Magyar Helsinki Bizottság; Pap András László, MTA TK Jogtudományi Intézet; Udvari Márton, NEKI; Uszkiewicz Erik, ELTE Állam- és Jogtudományi Kar

${ }^{693}$ GYEM szórólap.

${ }^{694}$ Átol [et al.], 2013, 81-82.

${ }^{695} \mathrm{~T} / 6958$. törvényjavaslat indokolás.
} 
elkészítette a közösség tagja elleni erőszak tényállásának részletes kommentárját. Számos szakmai konferenciát szervezett, ${ }^{696}$ emellett a GYEM tagjai szakmai és tudományos folyóiratokban is publikáltak a témakörben. Mindemellett több mint 70 rendörnek tartottak a csoport tagjai képzéseket, köztük a gyülölet-büncselekmények elleni szakvonal összes tagjának és a budapesti rendőri vezetőknek. Emellett, ami igazán előremutató, és a rendőrség részéről is jó gyakorlatként emelhető ki, hogy az Országos Rendör-főkapitányság gyülölet-büncselekmény szakvonal-vezetőjének kezdeményezésére rendszeresen egyeztet a munkacsoport a rendőrség és a Belügyminisztérium képviselőivel valamint független szakértők bevonásával, hogy az egyes vitatott eseteket megbeszéljék és közelítsék az álláspontokat. ${ }^{697}$

A joggyakorlat szempontjából leginkább nemrég indult és többnyire még kiforratlan kezdeményezések említhetőek, mint például a szakvonal kialakítása vagy a hamarosan induló - a Norvég Civil Támogatási Alap által finanszírozott - „Kezdeményezés a gyülölet alapú incidensek rendészeti kezelésének, valamint megelőzésének fejlesztésére" címü projekt. A projekt által kezelni kívánt probléma a gyülöletmotiválta incidensek Magyarországi növekedése. A különböző egyenruhás „masírozások” az esetek túlnyomó részében az adott településen élő kisebbségi csoportok ellen irányulnak. Éppen ezért a program a helyi társadalmi béke megőrzése és az erőszakos atrocitások megelőzése érdekében a helyi közösségeket és az eseményeket biztosító rendőri állományt igyekszik majd felkészíteni a gyülöletincidensek megfelelő kezelésére. Fontos eleme a programnak, hogy a közrendvédelmi parancsnoki állomány felkészítse, mind elméleti és gyakorlati szempontból egy a gyöngyöspatai helyzethez hasonló esemény komplex kezelésére, különös figyelemmel a kisebbséghez tartozó közösség tagjaival történő megfelelő eljárásmód elsajátítására. A képzéssorozatot amely valamennyi megyei rendőr-fökapitányság és a Készenléti Rendőrség érintett vezetői állományának bevonásával és együttmüködésével történik - a projektmegvalósító Európai Roma Rendvédelmi Bajtársi Közhasznú Egyesület munkatársai végezik majd, a rendőrség és a GYEM szakértőinek bevonásával. Külön érdeme a kezdeményezésnek, hogy széles körü rendőrségi és civil együttmüködésre

696 Például: MTA Rendészeti Albizottságával, lásd: http://gyuloletellen.hu/aktualitasok/gyuloletbuncselekmenyek-az-akademia-rendeszeti-albizottsaganak-ulesen (2014. december 4.); Magyar Rendészettudományi Társasággal és a Nemzeti Közszolgálati Egyetem Rendészettudományi Karával, lásd: http://gyuloletellen.hu/aktualitasok/konferencia-gyulolelet-buncselekmenyekrol (2014. december 4.) 697 Bővebben lásd GYEM: A Munkacsoport két éve az eredmények tükrében, http://gyuloletellen.hu/aktualitasok/munkacsoport-ket-eve-az-eredmenyek-tukreben (2014. december 5.) 
épít. Ezen együttműködés keretében pedig a régóta hiánycikknek számító gyülöletbüncselekmények rendőrségi kezelésével foglalkozó rendőrségi protokoll kidolgozására is vállalkozik a 2015 októberéig tartó projektidőszakban.

Az adatgyüjtés területéről jó gyakorlatként említendő, hogy egy önkéntes szakértőkből álló csoport éves jelentéseket készít antiszemita incidensekről. ${ }^{698}$ Az adatgyüjtés leginkább az internet tudatos és strukturált figyelésével és az incidensek regisztrálásával végezték. Ezen megfigyelések adatait havi rendszerességgel is publikálják elsősorban a zsidó közösségi vezetők számára. A havi jelentések minden regisztrált incidenssel egyenként foglalkoznak, míg az éves jelentések a különböző struktúrában a legfontosabb események kiemelése mellett az összefoglalásra törekednek. A hírek forrásai elsősorban a legnagyobb internetes hírportálok és közösségi oldal, lokális hírlapok, radikális weblapok, blogok és parlamenti közvetítések. A jelentések belső használatra készülnek, célközönségük a zsidó közösség vezetői és aktivistái, magyar és nemzetközi jogvédő szervezetek, nemzetközi lobbi csoportok.

Összefoglalóan elmondható, hogy a magyar jogalkotás és jogalkalmazás alapvetően progresszív irányt vett az elmúlt években, de rengeteg még a tennivaló. A jogi szabályozás számos területen csiszolható még, amellyel eredményesebbé lehetne tenni, mind a jogalkalmazást, mind az adatgyüjtés. A legfontosabb kérdések a Btk. által le nem fedett gyülölet-büncselekmények, így a rongálás és zaklatás tényállásának kiegészítése/átalakítása.

A jogalkalmazás területén rendkívül sok fejlesztendő terület van jelenleg. A rendőrséget illetően a szakvonal végleges formájának kialakításától, az állomány tagjainak képzésein keresztül a nyomozati protokollok kidolgozásáig. Amint erre a szakvonal jelentésében is rámutat, ${ }^{699}$ indokolt lenne az elöítéletesség jeleinek megismertetése a végrehajtó állománnyal, így képzéseket és tájékoztató anyagok eljuttatását követően az indikátorok alkalmazásával helyesen, gyülölet-büncselekménynek minősítenék az adott cselekményeket. Az ügyészség esetében ugyanúgy képzésekre és ügyészségi utasításokra lenne szükség e területen. Végül a bíróságok tekintetében elsősorban a helyes jogértelmezés érdekében a Kúriának kellene lépéseket tennie, főként a védett

698 MAZSIHISZ-Fórum az Antiszemitizmus Ellen: Antiszemita incidensek Magyarországon, 2014. Nyilvánosan nem hozzáférhető anyag.

${ }^{699}$ ORFK: 2011-2013-as időszakra vonatkozó jelentés, 29000/6903-2/2015. Ált. 
csoportok fogalmát illetően, a nyílt listából adódó bizonytalanságok, túlzottan tágra szabott védelmi keretek megszüntetése és magának a motivációnak a helyes értelmezése érdekében. Mindemellett a jogalkalmazóknak fel kellene tárni a hibákhoz vezető utat. Az igazságszolgáltatás esetében is elkerülhetetlen a „nyomon követés” egyfajta önrevízió keretében. Ha egyes tényállások alkalmazása tekintetében az mutatkozik, hogy a hibák száma kiugró, akkor a jogalkalmazóknak kísérletet tenni arra, hogy a tevékenség felülvizsgálatával feltárja milyen tényezők vezettek a hiábhoz. Ezt követő helyesbítéssel pedig olyan változásokat hozzanak létre, amelyek meggyőzik a társadalmat arról, hogy az igazságszolgáltatás minden tőle telhetőt megtesz a tévedések lehetőségének a minimumra szorítása érdekében. ${ }^{700}$

Az adatgyüjtés területén vár a legtöbb feladat Magyarországra. A rendszer jelenlegi formájában szemlátomást nem alkalmas a gyülölet-büncselekmények valós kiterjedésének felmérésére. Márpedig a jogalkotónak és a jogalkalmazó szerveknek is tényszerü adatokra van szüksége ahhoz, hogy felismerjék a probléma valós súlyát. Magyarország nemzetközi kötelezettségei is azt diktálják, hogy megbízható, nyilvános és releváns statisztikai adatok álljanak rendelkezésre a gyűlölet-büncselekményekre vonatkozóan.

Végül megjegyezendő, hogy a rendőrség kifejezetten jó irányba halad. Annak elismerése, hogy a területen jártas civilekkel való együttmüködés elösegítheti a munkájuk eredményességét mindenképpen elöremutató és a nemzetközi normák felé elmozdulást tükröző hozzáállás.

${ }^{700}$ Lásd Hack Péter: A büntetöhatalom függetlensége és számonkérhetösége. Budapest: Magyar Közlöny Lap- és Könyvkiadó, 2008. ill. Hack 2007, 4. 


\section{Összegzés, javaslatok}

A gyülölet-büncselekmények elleni fellépésre vonatkozó európai uniós és nemzetközi joganyagokat, ajánlásokat, külföldi és hazai jogot és jogalkalmazást, valamint az ezekhez kapcsolódó szakirodalmat áttekintve egyértelmü, hogy a gyülöletvezérelte büncselekményekre vonatkozó jogszabályok önmagukban kevésnek bizonyulnak a hatékony fellépés biztosítására. A büntető jogszabályoknak az azokat kiegészítő jogon kívüli intézkedésekkel együttesen lehet valós társadalmi hatása. A jogalkotás, jogalkalmazás, adatgyüjtés, áldozatsegítés és társadalmi tudatformálás egy komplex stratégiaként képes csak csatornába terelni a társadalomban meglévő indulatokat. Mindennek pedig előfeltétele, hogy megfelelő adatokkal és pontos ismeretekkel rendelkezzünk a gyülölet-büncselekmények áldozatairól, e büncselekmények elterjedtségéről. A hatósági kezelésére vonatkozó megbízható adatok összegyüjtése, elemzése és nyilvánosságra hozatala alapvető jelentőségü mind a széles társadalom, mind az érintett hatóságok tudatformálásához. A megbízható adatgyüjtési rendszer elősegíti a probléma teljes megértését és a hatékony fellépést. A megbízható adatok kulcsfontosságúak a gyülölet-bűncselekményekkel kapcsolatos szakpolitikák fejlesztéséhez, és segítik a lobbitevékenységet végző és áldozatok segítésével foglalkozó szervezetek munkáját. Az elöítélet-vezérelte büncselekmények elleni hatékony fellépést tehát két, egymást kiegészítő eszköz szolgálná: a jogszabályi tilalom, valamint az elöítéletek felszámolását szolgáló egyéb jogi és nem jogi eszközök.

Az egyes országok vizsgálatát követően megállapítható, hogy a büntető jogszabályokat egy hosszabb folyamat eredményeként alakították ki. A jogszabályok alkalmazása során felmerülő problémákra pedig módosításokkal, a jogalkalmazó szervekre szabott egyéni megoldásokkal válaszoltak, mindezt kiegészítve az áldozatoknak és a társadalom tagjainak szóló felvilágosító kampányokkal. A dolgozat képet adott a gyülöletbüncselekmények és állami kezelésük magyarországi helyzetéről, a hatékony fellépést akadályozó tényezőkről. A jelenlegi magyar jogszabályok és jogalkalmazás, a nemzetközi mintákkal egybevetve, négy - egymásra épülő - részterületen igényel korrekciót: jogalkotás; jogalkalmazás; adatgyüjtés; áldozattámogatás és társadalmi tudatformálás. 
A négy terület közül a jogalkotás igényli viszonylag a legkevesebb korrekciót. A hatályos jogszabályok alapvetően képesek lennének biztosítani a hatékony - a jelenleginél sokkal hatékonyabb - fellépést. ${ }^{701}$ A jogalkalmazási tevékenység későbbiekben részletezett - felülvizsgálata és a jogalkalmazást végző szervek számára nyújtott támogató jellegü intézkedések javarészt kompenzálhatnák a jogalkotásból eredő problémákat.

\section{1) Jogalkotás}

Első lépésként egy egységes - nemzetközi és hazai - gyülölet-büncselekmény fogalom kialakítása nagyban hozzájárulna a jogalkotás és jogalkalmazás hatékonyságának növeléséhez. Elősegítené nem csupán a hazai együttmüködést, de a gyülöletmotiválta cselekményekkel szembeni nemzetközi fellépést is. ${ }^{702}$

A Btk.-t illetően a közösség tagja elleni erőszak és egyéb büntetőrendelkezések kapcsán merülnek fel korrekciós pontok.

\section{A) Közösség tagja elleni eröszak}

Az első és legfontosabb kérdés a védett csoportok köre. Amint arra a dolgozat rámutatott, tárgyilagos mérlegelés szerinti akár ésszerü indokot képezhetne, ha a kisebbségekre szükítené le a jogalkotó a gyülölet-büncselekmények szabályozását; de nem a számszerü kisebbség értelmében, hanem a sérülékenység, a hátrányos helyzet, a történelmi tapasztalatok, a stigmatizáltság, a jelenkori társadalom elöítéletessége, valamin a rendszerszintű diszkrimináció fogalmi síkjain értelmezve. Ennek azonban a jelenlegi szabályozás és - különösen - a joggyakorlat nem felel meg. A védett csoportok körének „túltágítása” és a tényállás teljes kiüresedése többféleképpen is elkerülhető lenne.

\section{Zárt lista alkalmazása}

\footnotetext{
${ }^{701}$ Lásd pl. Dombos-Udvari 2014, 5.

702 A Facing Fact európai projekt folytatásaként 2015. március 3-4. között Brüsszelben tartott konferencián (,European Conference for a victim centered approach to tackling hate crimes”) nyolcvanhárom civil és nemzetközi szervezeti, rendőrségi, ügyészségi és egyéb állami képviselői, megfogalmazott ajánlásaik között elsőként e javaslatot fogalmazták meg a gyülölet-büncselekmények elleni fellépés hatékonyságának mérföldköveként. Lásd http://www.facingfacts.eu/article/press-releasefacing-facts-gives-significant-boost (2015. április 28.)
} 
Jogszabály módosítással, zárt lista alkalmazásával feloldható lenne a fenti probléma. Amint az angol tapasztalatok és minta mutatja, a zárt lista alkalmazásával biztosítható azon csoportok védelme, amelyek esetében a történelmi adottságok és a gyakran előforduló incidensek indokolttá teszik ezt. Ezzel pedig kiiktatható az a jogalkalmazási bizonytalanság, ami jelenleg is tapasztalható, főként a „magyarellenes” indíték kapcsán.

\section{Nyílt lista pontosítása}

A jelenlegi „lakosság egyes csoportjai” fordulat megtartásával is biztosítható a szabályozás, eredeti, kisebbségvédő funkciója. Ezt például az értelmező rendelkezések között elhelyezett fogalomeghatározással is megvalósítható lenne. ${ }^{703}$

\section{Nyílt lista és jogalkalmazók számára iránymutatás}

A jelenlegi jogszabályi keretek mellett is biztosítható a kisebbségvédő funkció. A Legfőbb Ügyész által kiadott körlevél, illetve a Kúria jogegységi döntése a „lakosság egyes csoportjai” fordulat értelmezése kapcsán ugyanúgy képes lenne megoldani a védett csoportokkal kapcsolatos jogalkalmazási problémákat. Azonban figyelembe véve a jelenlegi jogalkalmazási tendenciákat, a jogalkalmazóknak először a jelenlegi álláspont felülvizsgálatát kellene elvégezniük, tekintettel a „magyarellenes” indíték kapcsán kialakult konzekvens bírói gyakorlatra.

A védett csoportok mellett számos kérdés felvetődik a közösség tagja elleni erőszak tényállása kapcsán.

A hazai szakirodalomban a minősített esetek szabályozására vonatkozóan is találhatunk kritikát. Ugyanis a 216. § (3) bekezdése komolyan aránytalanságot hoz létre azáltal, hogy úgy épül rá mindkét alapesetre, hogy azok súlya között a minősített tényállás nem tesz különbséget eltérő büntetési tételekkel. Emellett az első alapesetekre épülve egyes minősítő körülmények nem is értelmezhetők (pl. sértett sanyargatása, jelentős érdeksérelem). Ez a hiba már az 1978. évi Btk.-ban is szerepelt, és a jogalkotó elmulasztotta kijavítani. ${ }^{704}$

\footnotetext{
${ }^{703}$ Lásd például GYEM: Javaslatok az új büntető törvény... 2012, 5.

${ }^{704}$ Lásd Karsai 2013, 454.
} 
Az előkészülettel kapcsolatban problémás lehet a közösség elleni erőszakra irányuló előkészület és a közösség elleni uszítás (Btk. 332. §) elhatárolása. Az uszítás mint elkövetési magatartás 2004 óta létező extrém szük értelmezése miatt az erőszakra irányuló előkészülettől szinte alig elhatárolható. Emellett abszurd ellentmondást okoz a büncselekmények büntetési tételének összevetése is, hiszen az egyén támadására közvetlenül irányuló elökészület büntetési tétele enyhébb, mint a köznyugalmat absztrakt módon veszélyeztető közösség elleni uszításé, amelynek következtében a verbális uszítóval ellentétben az, aki kést is ragad, és az utcára indul a célba vett személyek megtámadására (közösség tagja elleni erőszak előkészületét megvalósítva), enyhébb büntetési tétel alá esik. ${ }^{705}$

Végül tisztán látható, hogy nem alakult ki egységes joggyakorlat a halmazati kérdések kapcsán sem, és a jogirodalomra sem támaszkodhatunk az ellentmondások feloldása érdekében, hiszen ezen álláspontok is jelentősen eltérnek. Ezek alapján pedig akár azt is feltételezhetjük, hogy a problémák nem a jogalkalmazás szintjére, hanem a jogszabályokra vezethetők vissza és a jogalkotóra vár a kérdés megoldása. Mindezek tekintettel javasolt az értelmezések összhangját megteremtő lépéseket tenni.

B) Egyéb büntetőrendelkezések

A rongálás és zaklatás tényállásának kiegészítése/átalakítása is indokolt lenne az elöítélet motiváció figyelembe vétele érdekében. A rongálással kapcsolatos tapasztalatok azt mutatják, hogy a jogszabályi hiányosságok miatt a jogalkalmazás nem képes arra, hogy értékelje az előítélet-motivációból elkövetett dolog elleni erőszakot, amely nem pusztán az adott dolog, hanem - közvetve - a védett csoport tagja(i) ellen is irányul. Ilyen esetekben a hatóság nem a Btk. 216. § alapján nyomoz arra való hivatkozással, hogy konkrét személyeket nem érintett a cselekmény. Ettől függetlenül persze a bíróság súlyosító körülményként vehetné figyelembe az elöítélet-motivációt, azonban - mivel a tényállás nem tartalmazza az indítékot - a nyomozás erre az elemre nem terjed ki, így többnyire a bíró sem lesz olyan információk birtokában, amely alapján értékelhető lenne a súlyosító körülmény.

Az előítéletes zaklatás esetében is hasonló helyzet, mint a rongálás tényállásánál. A gyülölet-büncselekményként elkövetett zaklatást sem értékeli a jog, illetve a

\footnotetext{
${ }^{705}$ Erre a jogalkotói hibára Szomora Zsolt hívta fel a figyelmet. Lásd Szomora 2013, 42.
} 
jogalkalmazó a zaklatás (Btk. 222. §) tényállásán belül. Ezen szabályozási és jogalkalmazási hiányosság elhárítására is többféle megoldás kínálkozik, akár egy új fordulat formájában a közösség tagja elleni erőszak tényállásában, akár minősített esetként a rongáláson és zaklatáson belül. Amint azt a nemzetközi példák is mutatják a rongálás és zaklatás esetében is előfordul az előítélet-motívum minősített esetként történő szabályozása. ${ }^{706} \mathrm{Az}$ Egyesült Királyságban például a rongálás és a zaklatás esetében is minősített körülményként szabályozzák, ha az elkövetőt elöítélet motiválja, vagy elöítéletes érzelmeket mutat. ${ }^{707}$

A bírói gyakorlat konzekvensen arra az álláspontra helyezkedik, hogy az aljas indok magában foglalja az elöítélet-motivációt. Azonban a jogi képviseletet is ellátó civil szervezetek tapasztalata azt mutatja, hogy a jogalkalmazók sokszor nem ismerik fel az előítélet által vezérelt büncselekményeket. E probléma megoldása érdekében e szervezetek kétféle javaslattal is elöálltak. Egyrészt az aljas indok minősítő körülményéröl leválasztható lenne a „gyülölet-büncselekmények szempontjából védett csoportok tagjával szemben, a csoporthoz tartozás miatt történő elkövetés" ${ }^{708}$ A másik megoldás az aljas indok pontosítása például egy új értelmező rendelkezés formájában, amely az aljas indok lehetséges formái között tartalmazná a rasszista, antiszemita, homofób, transzfób és egyéb előítélet motívumokat. ${ }^{709}$ Emellett az elöítélet motiváció elkülönítése adatgyüjtési szempontból is indokolt lenne.

A jogalkotás kapcsán, a külföldi mintákat figyelembe véve megállapítható, hogy egészen eltérő megoldásokat alkalmaznak az államok. A különböző jogalkotási modellek mindegyikére, illetve vegyes rendszerekre is találunk példákat, és nincs is egyetlen tökéletesnek nevezhető megoldás sem. Egy jogszabály akkor válik a leghatékonyabbá és egyben kikényszeríthetővé, ha figyelemmel van az adott ország történelmi tapasztalataira, társadalmi berendezkedésére. Azonban a meglévő tapasztalok mindképp vezérfonalul szolgálhatnak a hatékony szabályozási háttér kialakítása során. Anglia esetében a vegyes rendszer például kifejezetten hatékonynak bizonyult, hozzájárulva a jogalkalmazás és adatgyüjtés sikereihez is.

\section{2) Jogalkalmazás}

\footnotetext{
${ }^{706}$ GYEM: Javaslatok az új büntetö törvény... 2012, 7-10.

${ }^{707}$ Crime and Disorder Act 1998 30. és 32. szakasz.

${ }^{708}$ GYEM: Javaslatok az új büntetö törvény... 2012, 15.

${ }^{709}$ Uo. 16.
} 
A jogalkalmazás területén rendkívül sok fejlesztendő terület van jelenleg. A jogalkalmazó szervek munkájának segítése két fő irányból lenne megoldható: a teljes állománynak és a szakvonal tagjainak szóló intézkedésekkel.

\section{A) Teljes állomány}

Az ORFK utasítás formájában adhatna iránymutatást gyülölet-büncselekmények kezelésére. Az iránymutatás kitérhetne a gyülölet-büncselekmények nyomozására, az áldozatok támogatására és a rendőrség megelőzéssel kapcsolatos feladataira is. ${ }^{710}$ Indokolt lenne az elöítéletesség jeleinek megismertetése a végrehajtó állománnyal, képzések és tájékoztató anyagok eljuttatásával a helyes minősítés érdekében. ${ }^{711}$ Elősegítene a gyülölet-büncselekményekkel szembeni hatékony fellépést például a tagok rendszeres továbbképzése a gyülölet-büncselekmények hatékony felderítésére a nemzetközi gyakorlatban elterjedt ún. indikátoralapú nyomozási technikáról, valamint a gyülölet-büncselekmények áldozatainak speciális szükségleteiről. Emellett képzésekre és figyelemfelhívó programokra lenne szükség helyi szinten is, hogy a helyi rendőrök felismerjék a gyülölet-bűncselekményeket és így az ügyek eljuthassanak a speciális szakértelemmel rendelkező szakvonal tagokhoz. Már a nyomozati szak elején pontosabban kellene rögzíteni az előítéletes indítékra vonatkozó információkat, akár az angol minta követésével az áldozat percepciója kiemelt fontosságú lehetne az eljárás megindításakor. Ha már az eljárás kezdeti szakaszában rögzítik a lehetséges motivációt, akkor kisebb az esélye a későbbi félreminősítéseknek. Egy másik megoldás, amit Angliában alkalmaznak, hogy gyülölet-büncselekményként kell rögzíteni minden olyan büncselekményt, amely az áldozat percepciója alapján előítélet által motivált. Mindezek fényében a leghatékonyabb megoldás, ha a lehető legtágabb megközelítést alkalmazzák a kezdeti besorolás során. ${ }^{712}$

Szintén megfontolandó az a javaslat, miszerint a nyomozás során indokolt lenne, hogy „a rendörség alkalmazza az elkövetö(k) beazonositására és az elöitéletes inditék bizonyítására alkalmas valamennyi nyomozati cselekményt, igy különösen az elkövetö hátterére, elöéletére vonatkozó adatok beszerzését, illetve a nemzetközi jogsegély-

\footnotetext{
${ }^{710}$ Lásd pl. Dombos-Udvari 2014, 6.

${ }^{711}$ ORFK: 2011-2013-as időszakra vonatkozó jelentés, 29000/6903-2/2015. Ált.

712 EESZ/DIEJH Hate rime Data-Collection ... 2014. 15-16.
} 
megkereséseket". ${ }^{713}$ Végül a teljesítményértékelési rendszerbe beépíthetnének olyan teljesítménymutatókat, amelyek a nehezebb jogi megítélésü ügyek esetén is ösztönzik a rendőröket és ügyészeket. ${ }^{714}$

B) Szakvonal

A szakvonal álláspontom szerint az egyik kanadai modell alapulvételével, sokkal hatékonyabban müködhetne. A kanadai Edmonton városában (és még több városban is) alkalmazott megoldás egyfajta vegyes szervezeti modellt alkalmaz. Az egység tagjai folyamatosan figyelemmel kísérik a különböző helyi szélsőséges csoportok és személyek tevékenységét, segítséget nyújtanak, illetve maguk is végeznek nyomozati cselekményeket, különböző oktatási feladatokat látnak el, valamint a jó gyakorlatok kialakításában és terjesztésében is aktívan részt vesznek. Az egység tagjai alapvetően a belső informatikai rendszeren belül értesülnek a potenciális gyülöletbűncselekményekről. A járőrök, illetve a rendőrség más tagjai a rendszerben megjelölik, ha előítélet-motiváció gyanúja merül fel, így a gyülölet-büncselekmények elleni egység azonnal értesül az esetről. ${ }^{715}$ Innentől kezdve kétféle alternatíva kínálkozik a nyomozati munkát illetően. Az esetek többségében csupán felügyeleti tevékenységet látnak el, de a nyomozást alapvetően az a körzet végzi, ahol a büncselekményt elkövették. Ilyen esetben a büntetőeljárást végig figyelemmel kísérik, szakmailag felügyelik, és segítséget nyújtanak a bizonyítékok gyüjtésében. Ha az ügy mélyebb nyomozást igényel, akkor teljesen átveszik a nyomozást. ${ }^{716}$ A szakvonal tagjainak rendszeres találkozóival és kapcsolattartásával pedig egységessé tehető országos szinten a fellépés.

Elösegítené a jelentési hajlandóságot, ha az áldozatok könnyen hozzáférhetnének a szakvonal tagjainak elérhetőségeihez és akár közvetlenül náluk is feljelentést tehetnének. Ez általánosságban történhetne a fénykép, elérhetőség közzétételével, nemzetközi minta alapján. Azonban jelen esetben csupán az elérhetőségek és nevek közzététele lehetséges, ugyanis egyes tagok a szakvonallal kapcsolatos feladatok mellett olyan tevékenységet is ellátnak, amely miatt fényképük nem hozható nyilvánosságra a

\footnotetext{
${ }^{713}$ Dombos-Udvari 2014, 6.

${ }^{714}$ Uo. 6.

715 Az kérdéses, hogy utóbbi a magyar Robotzsaru rendszerben megoldható-e. A rendszer teljes körü ismeretének hiányából fakadóan, a dolgozat keretei között nem tudunk állást foglalni.

716 Forrás: Dan Woodall-lal, a gyülölet-büncselekmények elleni egység tagjával 2014 augusztusában doktori kutatásom céljából - folytatott interjúkból származnak a fent található, az edmontoni rendőrség gyülöletbüncselekmény-elleni egységére vonatkozó információk.
} 
rendőrség honlapján. Többek között ebböl kifolyólag is a szakvonal kapcsán elsősorban azt kell eldönteni, hogy a szakvonal tagok kijelölésével egyben leveszik-e a vállukról az egyéb bűncselekményekkel kapcsolatos feladatokat. Egyrészt a többes feladatkör a fenti problémákhoz vezethet. Másrészt, ha a szakvonal megragad csupán például a kijelölés szintjén, azaz megjelölnek egy személyt megyei szinten, aki plusz feladatként megkapja a gyülölet-büncselekményekkel kapcsolatos feladatokat, akkor borítékolható, hogy a túlzott munkateher mellett képtelen lesz hatékonyan ellátni a feladatot (ahogy ez tapasztalható is a szakvonal jelenlegi müködésében).

A szakvonal hatékony müködéséhez az első lépés tehát, hogy megyei szinten legalább egy fő kizárólag a gyülölet-büncselekményekkel szembeni egységes fellépésért felel. Éppen utóbbi probléma kiküszöbölése érdekében javítani kell a szakvonal müködésének személyi feltételeit, különös tekintettel a fluktuáció csökkentésére és a tagok munkaterhelésének csökkentésére.

Ugyan a rendörség kifejezetten jó irányba halad a civilekkel való együttmüködés területén. Annak elismerése, hogy a területen jártas civilekkel való együttmüködés elősegítheti a munkájuk eredményességét mindenképpen előremutató és a nemzetközi normák felé elmozdulást tükrözö hozzáállás. Ezért kifejezetten javasolt ezen együttmüködés kereteinek bővítése és végső soron a civil szervezeti-rendőrségi együttmüködés akár olyan szintre emelése, amely a polgárőrséggel kapcsolatban állami szinten létezik.

\section{3) Adatgyüjtés}

Az adatgyüjtés, sajnos, igencsak kezdetleges, ami az elöítélet-vezérelte büncselekményeket illeti, illetve rendszintü problémák is tapasztalhatók. Az elmúlt évek statisztikáit tekintve nagyon csekély arányban jelennek meg gyülölet-büncselekmények. A gyülölet-büncselekményekre vonatkozóan állami szerveknél célzott adatgyüjtés nem folyik. Az adatgyüjtés területén vár a legtöbb feladat Magyarországra. Éppen ezért a rendszer jelenlegi formájában szemlátomást nem alkalmas a gyűlölet-büncselekmények valós kiterjedésének felmérésére. Márpedig a jogalkotónak és a jogalkalmazó szerveknek is tényszerü adatokra van szüksége ahhoz, hogy felismerjék a probléma valós súlyát. Magyarország nemzetközi kötelezettségei is azt diktálják, hogy 
megbízható, nyilvános és releváns statisztikai adatok álljanak rendelkezésre a gyülöletbüncselekményekre vonatkozóan.

Az első lépés a gyülölet-büncselekmények egységes statisztikai fogalmának bevezetése, a gyülölet-büncselekmények körébe tartozó valamennyi büncselekménytípusra kiterjedően. ${ }^{717}$ Amint a német tapasztalatok is mutatják, hatalmas elörelépést jelentett az egységes statisztikai fogalom bevezetése és hatóságok sokkal megbízhatóbb képet kapnak ma már a gyülölet-büncselekmények elterjedtségére vonatkozóan.

Egy másik jelentős probléma az adatgyüjtéssel kapcsolatban, hogy az adatbázisok teljesen függetlenek egymástól, így az abban szereplő ügyek nem is köthetőek egymáshoz. Így nem is lehet végigkövetni egy büncselekmény sorsát a bejelentéstől a büntetés kiszabásáig. Erre tekintettel mindenképp indokolt összekapcsolni a rendőrségi, ügyészségi és bírósági statisztikai adatgyüjtéseket.

Az ENYÜBS jelenlegi formájában szintén alkalmatlan a teljes körü adatgyüjtésre. Vagy általános jelleggel kellene feltüntetni az előítéletes motivációt, mint Kanadában (ahol elkövetési módszerként külön megjelölhető független a büncselekmény típusától) vagy ki kellene egészíteni a jelenlegi büncselekményeket más olyan tényállásokkal, ahol az elöítélet motiváció még felmerülhet. ${ }^{718}$

Mindenképp ajánlott éves jelentést készíteni - angol mintára - a gyülöletbüncselekményekkel kapcsolatos statisztikákból, amely kitér az esetek előfordulásának számára, a feljelentések sorsára és a kiszabott szankciókra is. Angliában, 2013-ban a Belügyminisztérium, Központi Statisztikai Hivatal és az Igazságügyi Minisztérium első ízben - átfogó közös jelentést publikált, amely a különböző forrásokból származó statisztikai adatokat összegzi. ${ }^{719}$ Egy ilyen kezdeményezés átvétele mindenképp megfontolásra érdemes. Szintén pozitívum az angol rendszerben, hogy rendszeres időközönként vesznek fel nagymintás áldozatkutatást, amely a gyülöletbüncselekmények előfordulására, jelentésére vonatkozóan is tartalmaz kérdéseket, és

\footnotetext{
${ }^{717}$ Lásd pl. Dombos-Udvari 2014, 8.

${ }^{718}$ Ilyen büncselekményként jelöli meg Dombos-Udvari 2014. az alábbiakat: zaklatás, rongálás, személyi szabadság megsértése, rágalmazás, jogellenes fogvatartás, alárendelt megsértése, szexuális erőszak, szexuális kényszerítés. Lásd Dombos-Udvari 2014, 8.

${ }^{719}$ Home Office, Office for National Statistics and Ministry of Justice: An Overview of Hate Crime in England and Wales, 2013. december, http://report-it.org.uk/files/ons_hate-crime-report_2013.pdf (2014. szeptember 7.)
} 
közelebb visz a valós adatokhoz. Magyarországon a Központi Statisztikai Hivatal végezhetne el egy ilyen áldozatkutatást meghatározott időközönként.

Mindemellett további kutatások segíthetnék a hatékony fellépést. Egyrészt a gyakorta áldozattá váló védett csoportok tagjai körében lehetne a gyülölet-büncselekményekkel, illetve a hatóság fellépésével kapcsolatos tapasztalataikról kutatás végezni, másrészt szükséges volna a rendőrök, ügyészek és bírák körében is az e csoportokkal kapcsolatos előítéletek feltérképezése. ${ }^{720}$

4) Áldozattámogatás és társadalmi tudatformálás

A fenti komplex rendszer támogatásául különböző megelőző és tudatformáló kezdeményezések is elengedhetetlenek. Ezek főként az alábbi területeket érinthetik: társadalmi figyelemfelhívó és tudatosságnövelő kezdeményezések, oktatási programok; bejelentési hajlandóságot növelő programok; hatósági és civil szervezeti együttmüködést kialakító és fejlesztő programok; az adatgyüjtést területét érintő kezdeményezések; különféle tudatosságnövelő, érzékenyítő és nyomozati eljárást érintő képzések a rendőrségen belül. Például szolgálhat az a németországi kezdeményezés, amelynek keretében a helyi önkormányzatok a helyi civil szervezetekkel együttműködve akciótervek keretében léptek fel a jobboldali szélsőségekkel szemben, különböző oktatási, tudatosságnövelő kampányok szervezésével. ${ }^{721}$ A rendőrségbe vetett általános bizalom növelésére, és a gyülölet-büncselekmények bejelentésének fontosságára történő célzott figyelemfelhívásra példa az angol True Vision, online bejelentési rendszer, amelyet a rendőrség, kormányzat és egyéb partnerintézmények közösen fejlesztettek ki és hoztak létre. A bejelentések megtételének lehetősége mellett az oldal különféle információval látja el az áldozatokat, illetve az áldozatoknak vagy szervezeteknek lehetőséget kínál arra, hogy az incidenst közvetlenül a hatáskörrel rendelkező rendőrségnél tegyék meg. Egy hasonló komplex megoldás a hazai problémákat megoldásához is nagyban hozzájárulna. Habár érdemes megjegyezni, hogy az áldozattámogatás jelenlegi állapotát tekintve bármilyen kisebb jellegü intézkedés is nagy elörelépést jelentene.

\footnotetext{
${ }^{720}$ Dombos-Udvari 2014, 8.

${ }^{721}$ Więcej-Opferpersektive 2009, 35.
} 
Összefoglalóan elmondható, hogy majd minden területen nagyobb figyelem övezi e büncselekményeket, mint néhány éve, és ezáltal részben progresszív irányt vett a jogalkotás és jogalkalmazás, de még mindig heves politikai és jogalkalmazói „ellenállás” tapasztalható a gyülölet-büncselekményekkel kapcsolatos diskurzusban. A jogalkalmazók továbbra is ódzkodnak a tényállás alkalmazásától, míg a kérdéskör mögött meghúzódó politkai akaratra csekély rálátás nyílik. Első lépésként mindenképp szükség lenne annak elimserésére, hogy a gyülölet-büncselekmények Magyarországon nem egy évi 15-20 eset számban megnyilvánuló problémát jelentenek, hanem ennnél sokkal súlyosabb a helyzet. Ennek beismerése vezethet egy határozottabb állásponthoz, amellyel elismernék a gyülölet-büncselekményekkel szembeni fellépés jelentőségét és szükségességét, mert végeredményben ez a mai napig nem történt meg.

Mindezek fényében mind a jogi szabályozás, mind a jogalkalmazás számos területen igényel még korrekciót, kiegészítve a fenti támogató programokkal. A gyülöletbüncselekményekkel szembeni fellépés hatékonysága kizárólag egy komplex stratgéia keretében valósítható meg, amellyel egyben az alapul szolgáló társadalmi problémák is kezelhetők lennének. Mint látható a gyülölet-büncselekményekkel kapcsolatos fellépés természetesen nem csupán (büntető)jogi feladat, de a büntetőjogi szabályozás tudatos, megfontolt, a társadalmi adottságokhoz igazodó alakításával az értékvédő jogág sokat tehet a társadalomban rejlő problémák megoldása érdekében.

A kézirat lezárása: 2015. agusztus 11. 


\section{Felhasznált irodalom:}

\section{Irodalom:}

1) ACPO: Hate Crime Operational Guidance. 2014, http://www.acpo.police.uk/documents/edhr/2014/140509\%20Hate\%20Crime\%20 Op\%20Guidance.pdf (2014. szeptember 20.)

2) ACPO: Hate Crime: Delivering a Quality Service. Good Practice and Tactical Guidance. 2005. http://www.bedfordshire.police.uk/pdf/tacticalguidance.pdf

3) Alapvető Jogok Biztosának Hivatala: AJB Projektfüzetek. A válság vesztesei - a paragrafusok fogságában projekt. 2013/3. (szerk.: Szajbély Katalin) http://www.ajbh.hu/documents/10180/124834/valsag_vesztesei_2013.pdf/11a861 9c-6093-47c7-89fd-90a9db7e34b9?version=1.1 (2015. június 28.)

4) Alapvető jogok biztosának hivatala: Beszámoló az alapvető jogok biztosának és helyetteseinek tevékenységéröl 2014. https://www.ajbh.hu/documents/10180/2119301/AJBH+Besz\%C3\%A1mol\%C3\% B3\%202014/e4cb6abb-2b16-4f67-bcdfe24ccb74cca2; jsessionid=A007B79F919184B39100BAEFFBD8C291 ?version=1. 0 (2015. február 10.)

5) Alapvető jogok biztosának hivatala: Beszámoló az alapvető jogok biztosának és helyetteseinek 2012. évi tevékenységéröl. http://www.ajbh.hu/documents/10180/129110/AJBH+Besz\%C3\%A1mol\%C3\%B 3\%202012/9215dc04-4031-451e-b79c-eff2e2e63925 (2015. február 10.)

6) Alapvető jogok biztosának javaslatai az új Büntető Törvénykönyv tervezetének társadalmi vitára bocsátásakor. Közérdekủ adatigénylés keretében a Háttér Társaság által megkért levél. Hiv.szám: XX-BKFO/47/2012.

7) Alke Glet: „The German Hate Crime Concept: An Account of the Classification and Registration of Bias-Motivated Offences and the Implementation of the Hate Crime Model into Germany's Law Enforcement", Internet Journal of Criminology, 2009, http://www.internetjournalofcriminology.com/Glet_German_Hate_Crime_Concep t_Nov_09.pdf (2014. november 5.) 
8) Amnesty International: Eröszakos támadások a romák ellen Magyarországon. Itt az idő a rasszista inditék kivizsgálására. 2010. 10. http://www.amnesty.hu/data/file/1279-

eroszakos_tamadasok_a_romak_ellen_eur270012010hu.pdf?version=1415642342 (2015. augusztus 1.)

9) Anti-Defamation

League:

Pyramid

of Hate. http://www.adl.org/assets/pdf/education-outreach/Pyramid-of-Hate.pdf (2015. augusztus 4.)

10) Athena Intézet: Gyülölet-büncselekmény adatbázis. http://athenaintezet.hu/gyuloletbuncselekmeny_lista (2013. november 30.)

11) Átol Dorottya [et al.]: „Közösség tagja elleni erőszak. Alternatív kommentár”, Fundamentum, 2013/3. 79-92.

12) ATV: Ezres tömeg vonult Devecserben a „cigánybünözés” ellen. 2012. http://www.atv.hu/belfold/20120805_devecser (2015. július 27.)

13) Az alapvető jogok biztosának jelentése az AJB-1199/2013. számú ügyben. 2013.

14) B.-A.-Z. Megyei Bűnmegelőzési Alapítvány, Bűnmegelőzési Szolgálat, Rendészeti hírlevél melléklete, Bünmegelözési ismeretek. http://www.bunmegelozes.eu/pdf/rendfebrmell.pdf (2013. szeptember 26.)

15) Balogh Lídia - Pap András László: „A homofób és transzfób indíttatású gyülöletbüncselekmények előfordulása, valamint a jogi fellépés keretei Magyarországon" in Takács Judit (szerk.): Homofóbia Magyarországon. Budapest: L’Harmattan, 2011. 128-139.

16) Balogh Lídia [et al.]: Antidiszkriminációs és esélyegyenlöségi alapismeretek, Budapest: L'Harmattan, 2009.

17) Barbara Perry - Patrik Olsson: "Hate Crime as a Human Rights Violation", in Barbara Perry and Paul Iganski (szerk.): Hate Crimes: The Consequences of Hate Crime, Vol 2, Westport: Praeger, 2009. 175-191.

18) Barbara Perry - Shahid Alvi: „'We are vulnerable': The in terrorem effects of hate crimes" International Review of Victomology, 2011/18. 57-71.

19) Barbara Perry (szerk.): Hate and Bias Crime, A Reader, New York: Routledge, 2003.

20) Barbara Perry: „Counting - and Countering - Hate Crime in Europe” European Journal of Crime, Criminal Law and Criminal Justice 2010/4. 349-367. 
21) Barbara Perry: In the Name of Hate. Understanding Hate Crimes. New YorkLondon: Routledge 2001.

22) Bárd Petra: „A gyülölet-büncselekmények hatékony üldözésének társadalmi feltételrendszere" in Borbíró Andrea [et al.] (szerk.): A büntetö hatalom korlátainak megtartása: a büntetés mint végső eszköz. Tanulmányok Gönczöl Katalin tiszteletére. Budapest: ELTE Eötvös Kiadó, 2014. 29-40. http://www.eltereader.hu/media/2014/05/Gonczol_READER.pdf (2015. március 5.)

23) Bárd Petra: „Gyülölt csoportok” http://szuveren.hu/jog/gyulolt-csoportok (2015. március 7.)

24) Belovics Ervin [et al.]: Büntetöjog I. - A 2012. évi C. törvény alapján. Budapest: HVG Orac Kiado, 2012.

25) Belovics Ervin-Tóth Mihály: Büntető eljárásjog. Budapest: HVG-ORAC, 2013.

26) Belügyminisztérium Koordinációs és Statisztikai Osztály, Legfőbb Ügyészség Informatikai Főosztály: Tájékoztató a 2012. évi bünözésröl. http://www.mklu.hu/repository/mkudok5892.pdf (2015. március 7.)

27) Bócz Endre: Négy évtized az ügyészségen. Pályám emlékezete. Budapest: Pallas, 2010.

28) Boross Zsigmond: „A gyülölet-büncselekmények aktuális magyarországi helyzete” Belügyi Szemle, 2013/12. 5-19.

29) Böszörményi Jenő (szerk.): Az ENSZ kisebbségi kézikönyve. Budapest, 2004. http://www.hunsor.se/dosszie/kissebbsegiKK.pdf (2014. március 5.)

30) Bradford and District: Hate Crime Strategy 2013-2016. http://www.bhca.info/documents/Bradford\%20Hate\%20Crime\%20Strategy\%202 013-16\%20-\%20final.pdf (2014. június 11.)

31) Bradford People First: Hate Crime Training. http://www.bradfordpeoplefirst.org.uk/hate-crime-training/ (2014. június 11.)

32) Busch Béla: „A személyiség büntetőjogi védelme, különös tekintettel a fegyveres testületek keretében megvalósuló deliktumokra II.” Rendészet és emberi jogok, 2011/2. 47-79.

33) Canadian Centre for Justice Studies: Hate Crime in Canada: An Overview of Issues and Data Sources. 2001. http://publications.gc.ca/Collection-R/Statcan/85551-XIE/0009985-551-XIE.pdf (2015. március 2.) 
34) CEJI - Zsidó Hozzájárulás a Befogadó Európához (A Jewish Contribution to an Inclusive Europe): Tegyünk láthatóvá a gyülölet-büncselekményeket. Nézzünk szembe a tényekkel! Útmutató a gyülölet-büncselekmények és elöitélet motiválta incidensek monitorozásához. 2012. http://www.ceji.org/media/facing-factsguidelines-hungarian.pdf (2014. Június 7.)

35) Chris Chapman: „The Role of Hate Speech and Hate Crime in the Escalation of Identity Conflict" in Peter Grant (szerk.): State of the World's Minorities and Indigenous People 2014. Minority Rights Group International. 34-39.

36) College of Policing: National Policing Hate Crime Strategy, 2014. http://www.report-it.org.uk/files/national_policing_hate_crime_strategy.pdf

37) Community Security Trust: A Guide to Fighting Hate Crime. http://www.thecst.org.uk/docs/Hate\%20Crime\%20booklet\%20\%20Web\%20version.pdf

38) Comparative Hate Crime Research Report, Oxford Pro Bono Publico, April 2014. http://ohrh.law.ox.ac.uk/wordpress/wp-content/uploads/2014/05/Oxford-ProBono-Publico-Comparative-Hate-Crime-Research-Report-April-2014.pdf

39) Council of Europe: Hungary: progress needed on media freedom, antidiscrimination measures and migrants' rigths. 16 December 2014. http://www.coe.int/en/web/commissioner/-/hungary-progress-needed-on-mediafreedom-anti-discrimination-measures-and-migrantsrights?inheritRedirect=true $\&$ redirect $=\mathrm{http} \% 3 \mathrm{~A} \% 2 \mathrm{~F} \% 2 \mathrm{Fwww} . \operatorname{coe} . \mathrm{int} \% 2 \mathrm{Fen} \% 2 \mathrm{~F}$ web\%2Fcommissioner\%2Fnews2014\%3Fp_p_id\%3D101_INSTANCE_Xlv41K37yewf\%26p_p_lifecycle\%3D0\% 26p_p_state\%3Dnormal\%26p_p_mode\%3Dview\%26p_p_col_id\%3Dcolumn1\%26p_p_col_count\%3D1 (2015. február 9.)

40) Crime Survey for English and Wales. http://www.crimesurvey.co.uk

41) CST: Antisemitic Incidents 2011. http://www.thecst.org.uk/docs/Incidents\%20Report\%202011.pdf (2014. október 29.)

42) Dan M. Kahan: „Two Liberal Fallacies in the Hate Crimes Debate” Law and Philosophy, 2001/2. 175-193.

43) Daniel Aisaka - Rachel Clune (szerk.): „Hate Crime Regulation and Challenges"The Georgetown Journal of Gender and the Law, 2013/2. 470-487. 
44) Danish Security and Intelligence Service, Politiets Efterretningstjenestes, PET https://www.pet.dk/English.aspx (2014. június 9.)

45) Danka Anita: „Rossz helyen lenni rossz időben, avagy mit üzennek a gyülöletbüncselekmények?" Föld-rész, 2009/3-4. 92-96.

46) Dhammika Dharmapala - Nuno Garoupa: „Penalty Enhancement for Hate Crimes: An Economic Analysis"American Law and Economics Review, 2004/1. $185-207$.

47) DIHR:

$$
\text { Action }
$$

against

Hate

Crimes. http://humanrightsvia.inforce.dk/focus+areas/equal+treatment/the+horizontal+app roach/projects/action+against+hatecrimes (2014. június 11.)

48) Dinók Henriett: „A gyülölet-büncselekmények: dogmatika és joggyakorlat”, Belügyi Szemle, 61. évfolyam, 2013. 52-67.

49) Dombos Tamás - Udvari Márton: Gyülölet-büncselekmények Magyarországon. Problémák, javaslatok, jó gyakorlatok. 2014. http://helsinki.hu/wpcontent/uploads/tanulmany.pdf (2015. március 26.)

50) Dombos Tamás „Gyülölet-büncselekmények Magyarországon: Jogi szabályozás, statisztikai adatok, sértetti csoportok" c. előadása, elhangzott: Magyar Tudományos Akadémia IX. Osztály Állam- és Jogtudományi Bizottság Rendészeti Albizottsága, 2013. március 8. A gyülölet-büncselekmények dogmatika és joggyakorlat címü tudományos ülés

51) EBESZ/DIEJH: Hate Crime Data-Collection and Monitoring Mechanisms. A Practical Guide. 2014. http://www.osce.org/odihr/datacollectionguide?download=true (2015. március 7.)

52) EBESZ/DIEJH: Hate Crime Laws. A Practical Guide, 2009. www.osce.org/odihr/36426 (2013. november 10.)

53) EBESZ/DIEJH: Hate Crime Monitoring. http://hatecrime.osce.org/what-do-weknow

54) EBESZ/DIEJH: Hate Crimes in the OSCE Region -- Incidents and Responses, $\begin{array}{llll}\text { Annual Report } & \text { for } & 2010, & \end{array}$ tandis.odihr.pl/hcr2010/pdf/Hate_Crime_Report_full_version.pdf (2014. március 7.)

55) EBESZ/DIEJH: Hate Crimes in the OSCE Region: Incidents and Responses. $\begin{array}{llll}\text { Annual } & \text { Report } & 2012 . & \end{array}$ 
http://tandis.odihr.pl/hcr2012/pdf/Hate_Crime_Report_full_version.pdf (2013. november 25.)

56) EBESZ/DIEJH: Prosecuting Hate Crimes. A Practical Guide. 2014. munkaanyaga. http://www.osce.org/odihr/prosecutorsguide? download=true $(2015$. április 15.)

57) EBESZ/DIEJI: Trainging Against Hate Crimes for Law Enforcement. Programme description. http://www.osce.org/odihr/tahcle?download=true (2013. november 25.)

58) EBH: Egyenlő Tájékoztató az Egyenlő Bánásmód Hatóság 2013. évi tevékenységéről. http://www.egyenlobanasmod.hu/article/view/tajekoztato-azegyenlo-banasmod-hatosag-2013-evi-tevekenysegerol-3 (2015. február 10.)

59) ECRI 1. sz. általános ajánlása: Küzdelem a rasszizmus, az idegengyülölet, az antiszemitizmus és az intolerancia ellen (ECRI General Policy Recommendation No. 1: Combating racism, xenophobia, antisemitism and intolerance) CRI(96)43 rev. 1996. http://www.europatanacs.hu/pdf/ECRI_1.pdf (2014. február 19.)

60) ECRI 11. sz. általános ajánlása: A rasszizmus és a faji megkülönböztetés ellen a rendfenntartás területén folytatott küzdelemröl (ECRI General Policy Recommendation No. 11: Combating racism and racial discrimination in policing) CRI(2007)39, 2007. http://www.europatanacs.hu/pdf/ECRI_11.pdf (2014. február 20.)

61) ECRI 13. sz. általános jelentése: Cigányellenesség és a romákkal szembeni diszkrimináció elleni küzdelem (ECRI General Policy Recommendation No. 13: Combating anti-Gypsyism and discrimination against Roma) CRI(2011)37, 2011. http://www.coe.int/t/dghl/monitoring/ecri/activities/gpr/en/recommendation_n13/e -RPG\%2013\%20-\%20A4.pdf (2014. március 1.)

62) ECRI 3. sz. általános ajánlása: Küzdelem a romákkal/cigányokkal szembeni rasszizmus és intolerancia ellen (ECRI General Policy Recommendation No. 3: Combating racism and intolerance against Roma/Gypsies) CRI(98)29 rev. 1998. http://www.europatanacs.hu/pdf/ECRI_3.pdf (2014. február 19.)

63) ECRI 4. sz. általános ajánlása: A potenciális áldozatok hátrányos megkülönböztetéssel és rasszizmussal kapcsolatos tapasztalatairól és benyomásairól végzett országos felmérések (ECRI General Policy Recommendation No. 4: National surveys on the experience and perception of 
discrimination and racism from the point of view of potential victims) CRI(98)30, 1998. http://www.europatanacs.hu/pdf/ECRI_4.pdf (2014. február 19.)

64) ECRI 5. sz. általános ajánlása: A muszlimokkal szembeni intolerancia és diszkrimináció elleni küzdelemről(ECRI General policy recommendation No. 5:Combating intolerance and discrimination against Muslims) CRI(2000)21, 2000. http://www.europatanacs.hu/pdf/ECRI_5.pdf (2014. február 19.)

65) ECRI 7. sz. általános ajánlása: A rasszizmus és a faji megkülönböztetés elleni küzdelem a nemzeti jogalkotásban (ECRI General Policy Recommendation No. 7: National Legislation to Combat Racism and Racial Discrimination) CRI(2003)8, 2002. http://www.europatanacs.hu/pdf/ECRI_7.pdf (2014. február 19.)

66) ECRI 9. sz. általános ajánlása: Az antiszemitizmus elleni küzdelemről(ECRI General Policy Recommendation No. 9: The fight against antisemitism) CRI(2004)37, 2004. http://www.europatanacs.hu/pdf/ECRI_9.pdf (2014. február 19.)

67) ECRI Magyarországról szóló első jelentés (ECRI's country-by-country approach: $\begin{array}{lllll}\text { Report on } & \text { Hungary) } & \text { CRI }\end{array}$ http://www.coe.int/t/dghl/monitoring/ecri/Country-by-country/Hungary/HUNCbC-I-1997-053-HU.pdf (2014. február 12.)

68) ECRI Magyarországról szóló harmadik jelentése (Third Report on Hungary) CRI (2004) 25, 2004. http://www.coe.int/t/dghl/monitoring/ecri/Country-bycountry/Hungary/HUN-CbC-III-2004-25-HUN.pdf (2014. február 12.)

69) ECRI Magyarországról szóló második jelentés (Second Report on Hungary) CRI (2000) 5, 2000. http://www.coe.int/t/dghl/monitoring/ecri/country-bycountry/hungary/HUN-CbC-II-2000-005-HUN.pdf (2014. február 12.)

70) ECRI Magyarországról szóló negyedik jelentése (ECRI Report on Hungary, fourth monitorting cycle) CRI (2009) 3, 2009. http://www.coe.int/t/dghl/monitoring/ecri/Country-by-country/Hungary/HUNCbC-IV-2009-003-HUN.pdf (2014. február 19.)

71) ECRI Magyarországról szóló ötödik jelentése (ECRI Report on Hungary, fourth $\begin{array}{lllll}\text { monitorting } & \text { cycle) } & \text { CRI } & \text { (2015) }\end{array}$ https://www.coe.int/t/dghl/monitoring/ecri/Country-by-country/Hungary/HUNCbC-V-2015-19-HUN.pdf (2015. június 26.)

72) ECRI: „Ethnic” statistics and data protection in the Council of Europe countries, Study Report by Patrick Simon, Strasbourg, 2007. 
www.coe.int/t/dghl/monitoring/ecri/activities/themes/Ethnic_statistics_and_data_ protection.pdf (2014. február 19.)

73) Edmonton Police Service: an exciting policing career awaits you in Edmonton, Alberta.

Canada. http://www.joineps.ca/ApplicationProcess/ /media/Join\%20EPS/Files/An\%20exc iting\%20policing\%20career\%20awaits\%20you.ashx (2014. október 29.)

74) EIGE: A Nemek Közötti Egyenlöség Európai Intézetének éves jelentése, 2010. http://eige.europa.eu/sites/default/files/AR-HU.pdf (2014. március 31.)

75) Elizabeth A. Stanko: „Re-conceptualising the Policing of Hatred: Confessions and Worrying Dilemmas of a Consultant" Law and Critique, 2001/13. 309-329.

76) Elizabeth Burney - Gerry Rose: "Racist offences - how is the law working? Implementation of the legislation on racially aggravated offences in the Crime and Disorder Act 1998", Home Office Research Study 244, July 2002. http://webarchive.nationalarchives.gov.uk/20110218135832/rds.homeoffice.gov.u k/rds/pdfs2/hors244.pdf (2015. február 24.)

77) Enyedi Zsolt - Fábián Zoltán - Sik Endre: „Nőttek-e az elöítéletek Magyarországon? Antiszemitizmus, cigányellenesség és xenofóbia változása az elmúlt évtizedben" in Kolosi [et al.] (szerk.): Társadalmi riport 2004. Budapest: TÁRKI, 375-399. http://www.tarki.hu/adatbank-h/kutjel/pdf/a809.pdf (2015. augusztus 1.)

78) Equinet European Network of Equality Bodies: Stop Hate Crimes kampány. http://www.equineteurope.org/Stop-Hate-Crimes-campaign-Denmark

(2014. június 10.)

79) ERRC - NEKI -TASZ: Jelentés a 2009. február 23-án, Tatárszentgyörgyön történt kettős gyilkosság körülményeiről és az eljáró hatóságok munkájáról. Budapest. $2009.2 \quad$ http://dev.neki.hu/wpcontent/uploads/2013/05/tat\%C3\%A1rszentgy\%C3\%B6rgyi-jelent\%C3\%A9s.pdf (2015. július 28.)

80) FRA: Discrimination and Hate Crimes against Jews in EU Member States: experiences and perceptions of antisemitism, 2013. http://fra.europa.eu/sites/default/files/fra-2013-discrimination-hate-crime-againstjews-eu-member-states_en.pdf (2014. március 5.) 
81) FRA: Esettanulmány. A romák lakóhelyi szegregációja elleni küzdelem, Magyarország. 2009. http://fra.europa.eu/sites/default/files/fra_uploads/602ROMA_Housing_Case-final-HU.pdf (2015. július 10.)

82) FRA: Gyülölet-büncselekmények az Európai Unióban, 2013. http://fra.europa.eu/sites/default/files/fra-factsheet_hatecrime_hu_final.pdf (2014. március 30.)

83) FRA: Making hate crime visible in the European Union: acknowledging victims' rights, 2012. http://fra.europa.eu/sites/default/files/fra-2012_hate-crime.pdf (2014. március 30.)

84) FRA: Zsidók hátrányos megkülönböztetéssel és gyülölet-büncselekményekkel kapcsolatos tapasztalatai az Európai Unió tagállamaiban, 2013. 3-4. http://fra.europa.eu/sites/default/files/fra-2013-factsheet-jewish-peopleexperiences-discrimination-and-hate-crime-eu_hu.pdf (2014. március 3.)

85) Frederick M. Lawrence: Punishing Hate: Bias Crimes Under American Law, Cambridge, Ma: Harvard University Press, 1999.

86) Fundamental Rights Conference: Combating Hate Crime in the EU. Giving Victims a face and a voice. Vilnius, Litvánia, 2013. novemeber 12-13., Working Group reporting back. http://fra.europa.eu/sites/default/files/frc_2013_day_2_wg_iii_working_group_ha rvest_capacity_building_and_training.pdf (2014. november 3.)

87) Gary Reid: The Role of the Police in Adressing Hate Crime: The Case of the $\begin{array}{llll}\text { Police } & \text { Service } & 2013 .\end{array}$ http://www.enargywebzine.eu/spip.php?article306 (2014. augusztus 7.)

88) General Social Survey on Victimization (GSS), 2009. http://www.statcan.gc.ca/pub/85-002-x/2010002/article/11340-eng.htm (2014. augusztus 8.)

89) George Orwell: Burmai napok (ford. Máthé Elek), Budapest: Terebess Kiadó, 1998.

90) Georgina Ashworth: Of Violence and Violation Women and Human Rights, London: Change, 1986.

91) Godfred Chongatera: „Hate-Crime Victimization and Fear of Hate Crime Among Racially Visible People in Canada: The Role of Income as a Mediationg Factor” Journal of Immigrant and Refugee Studies, Vol. 11., 2013, 44-64. 
92) Government of Canada, Statistics Canada: Police-reported hate crime in Canada, 2012. http://www.statcan.gc.ca/pub/85-002-x/2014001/article/14028-eng.htm\#r1 (2014. augusztus 7.)

93) Görgényi Ilona [et al.]: Magyar Büntetőjog - Különös rész. Budapest: Complex Kiadó, 2013.

94) Gregory M. Herek [et al.]: „Victim Experiences in Hate Crimes Based on Sexual Orientation" Journal of Social Issues, 2002/2. 243-259.

95) Gregory R. Nearpass: „The Overlooked Constitutional Objection and Practical Concerns to Penalty-Enhancement Provisions of Hate Crime Legislation" Albany Law Review, 2003/2. 547-573.

96) GYEM által kezdeményezett közérdekü adatigénylés keretében rendelkezése bocsátott jelentés. ORFK: 2011-2013-as időszakra vonatkozó jelentés, 29000/6903-2/2015. Ált.

97) GYEM: A Gyülölet-büncselekmények elleni munkacsoport véleménye a rendörség nyomozó hatóságainak hatásköréröl és illetékességéröl szóló rendelet tervezetéröl, http://gyuloletellen.hu/sites/default/files/hataskorirendelet_2013-0605.pdf (2013. szeptember 25.)

98) GYEM: A Munkacsoport két éve az eredmények tükrében. 2014. http://gyuloletellen.hu/aktualitasok/munkacsoport-ket-eve-az-eredmenyektukreben (2014. december 5.)

99) GYEM: Az új Büntetö törvénykönyv gyülölet-büncselekményekre vonatkozó rendelkezéseinek kialakítása során figyelembe veendö szempontok. 2012. http://gyuloletellen.hu/sites/default/files/hatteranyag_2012-02-22.pdf szeptember 25.)

100) GYEM: Esetek, “Milla”. http://gyuloletellen.hu/node/40 (2015. április 21.)

101) GYEM: Európa Tanács: Képezni kell a rendőröket, ügyészeket, bírákat. 2015. http://gyuloletellen.hu/aktualitasok/europa-tanacs-kepezni-kell-rendoroketugyeszeket-birakat (2015. február 11.)

102) GYEM: Javaslatok az új Büntető Törvénykönyv gyülölet-büncselekményekre vonatkozó szabályozására. 2012. gyuloletellen.hu/sites/default/files/btkvelemeny_2012-03-06.pdf (2013. szeptember 25.)

103) GYEM: Jogalkalmazási problémák a gyülölet-büncselekményekkel kapcsolatos eljárásokban. A Gyülölet-büncselekmények Elleni Munkacsoport (GYEM) 
tapasztalatai.

http://gyuloletellen.hu/sites/default/files/ejk_esetosszefoglalo.pdf november 26.)

104) GYEM: Közérdekű adatigénylés, Legfőbb Ügyészség, Ig. 106/31/2014. Legf. Ü. szám.

105) GYEM: Közérdekű adatigénylés, Legfőbb Ügyészség, Ig. 42/8/2015. Legf.Ü. szám

106) Hack Péter: A büntetőhatalom függetlensége és számonkérhetösége. Budapest: Magyar Közlöny Lap- és Könyvkiadó, 2008.

107) Hack Péter: Az igazságszolgáltatás kudarcai. Vizsgálatok és megoldások az angolszász jogrendszerben. Az előadás elhangzott a Magyar Büntetőjogi Társaság rendezvényén, 2007. április 19-én. http://www.mbjt.hu/HackPeter20070419.pdf (2015. május 10.)

108) Halmai Gábor: Kommunikációs jogok. Budapest: Új Mandátum, 2002.

109) Harald Weilnböck: Hate Crime and Radicalisation: the German Political Experience and the Schellenberg Report. 2012. http://www.niacro.co.uk/filestore/documents/hate_crime_project_papers/08_Hate _Crime_and_Radicalisation__the_German_political_experience_and_the_Schellenberg_Report.pdf (2014. november 3.)

110) Háttér Társaság: Submission by Háttér Support Society for LGBT People in Hungary for the OSCE ODIHR 2010 annual report on hate crimes. http://www.hatter.hu/kiadvanyaink/osce-hatecrime-2010 (2013. december 2.)

111) Havas Gábor - Kertesi Gábor - Kemény István: „The Statistics of Deprivation. The Roma in Hungary"Hungarian Quarterly, 36. 1995. No. 1. 67-80.

112) Heidi M. Hurd: „Why Liberals Should Hate »Hate Crime Legislation«” Law and Philosophy, 2001/2. 215-232.

113) Helen Ahm Lim: "Beyond the Immediate Victim: Understanding Hate Crimes as Message Crimes" in Barbara Perry and Paul Iganski (szerk.): Hate Crimes: The Consequences of Hate Crime, Vol 2, Westport: Praeger, 2009. 107-122.

114) Helsinki Bizottság: „A közösség tagja elleni erőszak (Btk. 174/B. §) bírósági aktaelemzéssel” című kutatás kézirata 
115) Helsinki Bizottság: Etnikai mocskolódás és megkövezés „,békés jelleggel”. 2012. http://helsinki.hu/etnikai-mocskolodas-es-megkovezes-\%E2\%80\%9Ebekesjelleggel\%E2\%80\%9D (2015. július 28.)

116) Hollán Miklós: „A személyes tulajdonságok és körülmények tana” in Hajdú József (szerk.): 90 éves a szegedi jogászképzés, Szeged, 2013.

117) Home Office, Office for National Statistics and Ministry of Justice: An Overview of Hate Crime in England and Wales, 2013. december, http://reportit.org.uk/files/ons_hate-crime-report_2013.pdf (2014. szeptember 7.)

118) Human Rights Watch: The State Response to "Hate Crimes" in Germany. Human Rights Watch Briefing Paper, 2011, Police Response to Hate Crimes. http://www.hrw.org/news/2011/12/09/state-response-hate-crimes-germany (2014. november 5.)

119) HVG: Börtönbe zárná a Jobbik a melegeket, http://hvg.hu/itthon/20120411_jobbik_tervezet (2013. szeptember 26.)

120) HVG: Feljelentésen gondolkodik a pályaudvaron verekedö örök ügyvédje. 2015. http://hvg.hu/itthon.bunugy/20150421_palyaudvaron_verekedo_orok (2015.július 20.)

121) HVG: Toroczkaival vonul a Jobbik a halálbüntetés mellett. 2012. http://hvg.hu/itthon.parlament/20120805_Jobbik_Devecser (2015. július 27.)

122) IACP: Responding to Hate Crimes: A Police Officer's Guide to Investigation and Prevention. http://www.theiacp.org/HateCrimesOfficerGuide (2015. február 5.)

123) ILGA: Joining Forces to Combat Homophobic and Transphobic Hate Crime: Cooperation between Police Forces and LGBT Organizations in Europe. 2010.

124) ILGA: Project by carried out by the DIHR: Tracing and Tackling Hate Crime against LGBT Persons. http://www.ilgaeurope.org/home/issues/hate_crime_hate_speech/projects/dihr (2014. Június 11.)

125) Index: Elfogták a romák elleni támadások gyanúsítottjait. 2009. http://index.hu/bulvar/2009/08/21/elfogtak_a_romak_elleni_tamadasok_gyanusito ttjait/ (2015. július 27.)

126) Index: Fiatalkorúak rugdostak meg egy hajléktalant. 2013. http://index.hu/belfold/2013/11/16/fiatalkoruak_rugdostak_meg_egy_hajlektalant/ (2015. július 20.) 
127) Index: Jogerős: feloszlatták a Szebb Jövőért Egyesületet. 2014. http://index.hu/belfold/2014/10/08/jogeros_feloszlatjak_a_szebb_jovoert_egyesul etet/ (2015. július 19.)

128) Iris Marion Young: „Five Faces of Oppression” in Dean Harris (szerk.): Multiculturalism from the margins. Westport: Bergin and Garvey, 1995. 65-86.

129) Jack McDevitt [et al.]: „Consequences for Victims. A Comparison of Bias- and Non-Bias-Motivated Assaults" American Behavioral Scientist, 2001/4. 139-151.

130) James B. Jacobs: "The Emergence and Implications of American Hate Crime Jurisprudence", In. Barbara Perry (ed.): Hate and Bias Crime, A Reader, New York: Routledge, 2003. 409-426.

131) James Weinstein: „First Amendment challenges to hate crime legislation: Where's the speech?" Criminal Justice Ethics, 1992/2. 6-20.

132) Jan van Dijk [et al.]: The Burden of Crime in the EU. Research Report: A Comparative Analysis of the European Crime and Safety Survey (EU ICS) 2005. http://www.unicri.it/services/library_documentation/publications/icvs/publications /EUICS_-_The_Burden_of_Crime_in_the_EU.pdf (2015. március 10.)

133) Jane Roberts Chapman: "Violence Against Women as a Violation of Human Rights" Social Justice, 1990/2. 54-70.

134) Jeannine Bell: Policing Hatred. Law Enforcement, Civil Rights, and Hate Crime. New York University Press, 2002.

135) Jeffrey Ian Ross: „Hate Crime in Canada: Growing Pains with New Legislation” in Mark S. Hamm (szerk.): Hate Crime: International Perspectives on Causes and Control, Cincinnati: Anderson Publishing, 1994, 151-172.

136) Jessica Malloy-Thorpe - David Hemken (szerk.): „Hate Crime Regulation and Challenges" The Georgetown Journal of Gender and the Law, 2012/2. 290-306.

137) Jordan Blair Woods: „Taking the »Hate« Out of Hate Crimes: Applying Unfair Advantage Theory to Justify the Enhanced Punishment of Opportunistic Bias Crimes", UCLA Law Review, 2008/2. 489-541.

138) Jovánovics Eszter - Pap András László: „Kollektív bünösség a 21. század Magyarországán: magyarellenesség vádja cigányokkal szemben két emblematikus perben" Fundamentum 2013/3. 153-157.

139) Jovánovics Eszter: Az egyik szerint garázda a másik szerint rasszista. http://ataszjelenti.blog.hu/2013/10/15/az_egyik_szerint_garazda_a_masik_szerint _rasszista (2015. március 19.) 
140) Julia Sandler: Hate Motivation as an Aggravating Factor on Sentence: An Overview of the Legal 2010. http://www.law.utoronto.ca/documents/conferences2/CombatingHatred10_Sandle r.pdf (2014. szeptember 10.)

141) Kállai Ernő, nemzeti és etnikai kisebbségi jogok országgyűlési biztosának levele Navracsics Tibor, közigazgatási és igazságügyi miniszternek. 2011. április 5. http://www.kisebbsegiombudsman.hu/data/files/202083196.pdf (2015. június 26.)

142) Kállai Ernő: Megszüntetve a kisebbségi ombudsman összegzése. Budapest, 2011. http://www.kisebbsegiombudsman.hu/data/files/223773024.pdf (2015. június 28.)

143) Karen Franklin: „Good Intentions: The Enforcement of Hate Crime PenaltyEnhancement Statutes" American Behavioral Scientist. 2002/1. 154-172.

144) Karsai Krisztina (szerk.): Kommentár a Büntetö Törvénykönyvhöz (Kommentár a Büntetö Törvénykönyvröl szóló 2012. évi C. törvényhez). Budapest: Complex Kiadó, 2013.

145) Kis János: „Az állam semlegessége. Újabb nekifutás” Fundamentum, 2011/3. 522.

146) Kis Norbert - Hollán Miklós: Büntetőjog I. -- Az anyagi büntetőjog általános része, Büntetöjogi ismeretek a közszolgálati szakemberképzés számára. Budapest: Dialóg Campus, 2008.

147) Kis Norbert - Hollán Miklós: Büntetőjog I. - Az anyagi büntetőjog általános része - Alapismeretek a közigazgatási szakemberképzés számára. 2. átdolgozott kiadás, Budapest: Dialóg Campus Kiadó, 2013.

148) Kis Norbert - Hollán Miklós: Büntetőjog II. - Az anyagi büntetőjog különös része. Alapismeretek a közszolgálati szakemberképzés számára. Budapes-Pécs: Dialóg Campus Kiadó, 2011.

149) Koltay András (szerk.): A gyülöletbeszéd korlátozása Magyarországon. Budapest: CompLex, 2013.

150) Koltay András: „A gyülöletbeszéd korlátozásának elméleti szempontjai” Iustum aequum salutare, 2011/3. 111-124.

151) Koltay András: „A nagy magyar gyülöletbeszéd-vita: a »gyülöletre uszítás« alkotmányos mércéjének azonosítása felé”Állam- és Jogtudomány, 2013/1-2. 91123. 
152) Koltay András: „A nagy magyar gyülöletbeszéd-vita: A »gyülöletre uszítás« alkotmányos mércéjének azonosítása felé” Állam- és Jogtudomány, 2013/1-2.91123.

153) Koos Postma: „A cigányokkal szembeni előítélet alakulása Magyarországon"Regio- Kisebbség, politika, társadalom. 1998/1., 109-127. (ford. Victor Mónika)

154) Kovács Mónika: „Az elöítéletek okai és mérséklésük lehetőségei: a szociálpszichológiai nézőpont”Alkalmazott pszichológia, 2010/1-2. 7-27.

155) Központi Statisztikai Hivatal: 2011. évi népszámlálás. 3. Országos adatok. 7. http://www.ksh.hu/docs/hun/xftp/idoszaki/nepsz2011/nepsz_orsz_2011.pdf 2015. augusztus 4.)

156) Krémer Ferenc hozzászólása, Magyar Tudományos Akadémia IX. Osztály Államés Jogtudományi Bizottság Rendészeti Albizottsága, 2013. március 8. A gyülöletbüncselekmények - dogmatika és joggyakorlat címü tudományos ülésen

157) Kulcsár Anna: Közösség tagja elleni eröszakért szabadságvesztés. http://mno.hu/belfold/kozosseg-tagja-elleni-eroszakert-szabadsagvesztes-1160147 (2013. október 30.)

158) Law Commission: Consultation Paper No. 213, Hate crime: The Case for Extending the Existing Offences. A Consultation Paper. 2013. http://lawcommission.justice.gov.uk/docs/cp213_hate_crime_amended.pdf (2015. június 15.)

159) Lázár Guy: „A felnőtt lakosság nemzeti identitása a kisebbségekhez való viszony tükrében” in Terestyéni Tamás (szerk.): Többség - kisebbség. Tanulmányok a nemzeti tudat témaköréböl. Budapest: Osiris - MTA-ELTE Kommunikációelméleti Kutatócsoport, 1996. 9-115.

160) Lázár Guy: „A kisebbségek szerepe a nemzeti identitás kialakulásában”Regio Kisebbség, politika, társadalom. 1995/1-2., 28-63.

161) Magyar Értelmezö Kéziszótár, Budapest: Akadémia Kiadó, 1992. 491.

162) Majtényi Balázs: „Az ENSZ és a kisebbségek védelme” Kisebbségkutatás, 2003/1. http://www.hhrf.org/kisebbsegkutatas/kk_2003_01/cikk.php?id=489 (2014. február 11.)

163) Mario Peucker: The hate crime concept in Germany and how to improve the knowledge on the extent of hate crimes, Paper prepared for the OSCE meeting "Tolerance Implementation Meeting: Addressing the hate crime data deficit" 
(Vienna, 8-10 November 2006), Bamberg 2006. http://www.efms.unibamberg.de/pdf/Hate_crime_concept_final.pdf

164) MAZSIHISZ-Fórum az Antiszemitizmus Ellen: Antiszemita incidensek Magyarországon, 2014.

165) Medián: Fagypont körül. 2009. http://www.median.hu/object.2a6fb495-9b954bb7-89ff-1a5942f27c9f.ivy (2015. augusztus 7.)

166) Mészáros Ádám: „Jogfilozófia és igazságosság a büntetőjogban. Az in dubio mitius elve" Acta Publ. doct. jur. Tomus IV. Szeged, 2004. 391-413.

167) Metropolitan Police: Community Safety Unit. http://content.met.police.uk/Site/communitysafetyunit (2014. szeptember 7.)

168) Mia Dauvergne - Shannon Brennan: Police-reported hate crime in Canada, 2009, Juristat. Self-reported victimization data on hate-motivated incidents. http://www.statcan.gc.ca/pub/85-002-x/2011001/article/11469-eng.htm (2014. augusztus 8.)

169) Michael Stewart: Foreword: New Forms of Anti-Gypsy Politics: A Challengefor Europe. In Michael Stewart (szerk.): The Gypsy 'Menace'. Populism and the New Anti-Gypsy Politics. London: Hurst \& Company. 2012.

170) Ministry of Attorney General: End Hate Crime: B.C. Hate Crime Team Roles and Responsabilities. http://www.ag.gov.bc.ca/prosecutionservice/pdf/EndHateCrimes_booklet.pdf (2014. szeptember 10.)

171) Mohamed Al-Hakim: „Making Room for Hate Crime Legislation in Liberal Societies" Criminal Law \& Philosophy, 2010/3. 341-358.

172) Molnár Sándor: „A büntetés kiszabása során figyelembe vehető körülmények” Jogi Fórum, 2011. http://www.jogiforum.hu/files/publikaciok/molnar_sandor_bunteteskiszabas\%5B jogi_forum\%5D.pdf (2015. február 18.)

173) Nagy Ferenc: A magyar büntetőjog általános része. Budapest: HVG-ORAC, 2008.

174) Nathan Hall: „Law Enforcement and Hate Crime: theoritical perspectives on the complexities of policing 'hatred" in Neil Chakraborti (szerk.): Hate Crime. Concepts, policy, future directions. Willan Publishing, 2010, 149-168.

175) Neil Kressel: Mass Hate: The Global Rise of Genocide and Terror. Cambridge: Westview Press, 2002. 
176) Neményi Mária [et al.]: Az egyenlö bánásmóddal kapcsolatos jogtudatosság növekedésének mértéke - fókuszban a nök, a romák, a fogyatékos és az LMBT emberek. Kutatási zárójelentés. Budapest, 2011. április 30. http://www.egyenlobanasmod.hu/tamop/data/MTA_1hullam.pdf (2015. március 10.)

177) Németh Imre: „Elmélkedés a büntetendővé nyilvánítás értéktartalmáról” in Szoboszlai-Kiss Katalin-Deli Gergely (szerk.): Tanulmányok a 70 éves Bihari Mihály tiszteletére. Győr: Universitas-Győr Nonprofit Kft., 2013, 361-368.

178) Nemzeti és Etnikai Kisebbségi Jogok Országgyülési Biztosa: Beszámoló a Nemzeti és Etnikai Kisebbségi Jogok Országgyülési Biztosának tevékenységéröl, 1998. január 1.-1998. 31. http://www.kisebbsegiombudsman.hu/word/08-062008_13_55_16/beszámoló_2008.html (2014. február 19.)

179) Nemzeti Társadalmi Felzárkózási Stratégia - mélyszegénység, gyermekszegénység, romák - (2011-2020). KIM Társadalmi Felzárkózásért Felelős Államtitkárság. $\quad$ Budapest, 2011. http://romagov.kormany.hu/download/8/e3/20000/Strat\%C3\%A9gia.pdf (2015. augusztus 4.)

180) Népszabadság Online: Fegyelmi a romagyilkosok perének bírája ellen. 2014. http://nol.hu/belfold/fegyelmi-miszori-biro-ellen-1473095 (2015. július 29.)

181) Népszava Online: Romagyilkosságok: a Kúrián folytatódik a per. 2015. http://nepszava.hu/cikk/1056594-romagyilkossagok-a-kurian-folytatodik-a-per (2015. július 29.)

182) Nigdy Więcej - Opferpersepektive (szerk.): Hate Crime Monitoring and Victim Assistance in Poland and Germany. 2009. http://www.stiftungevz.de/fileadmin/user_upload/EVZ_Uploads/Publikationen/Englisch/poland_full_ english.pdf (2014. november 6.)

183) Novoszádek Nóra - Rácz Dominika: „Gyűlöletvezérelt büncselekmények európai szabályozási mintái” Föld-rész, 2009/3-4. 63-80.

184) OKRI: Áldozatkutatás. http://www.okri.hu/content/view/191/165 (2015. március 26.)

185) OKRI: Állásfoglalás a magyarországi bünözési helyzetről, az elkövetők etnikai hovatartozásának nyilvántartásáról és a „cigánybünözésről. Budapest: Országos Kriminológiai Intézet, 2009. 2-3. 
186) Origo: Életük végéig tartó börtönre itélték a cigánygyilkosokat. 2013. http://www.origo.hu/itthon/20130805-iteletet-hoznak-a-romagyilkossagokugyeben.html (2015. július 29.)

187) Origo: Ilyen országban élünk. 2014. http://www.origo.hu/filmklub/blog/kritika/20140520-ilyen-orszagban-elunk-iteletmagyarorszagon-kritika-hajdu-eszter-romagyilkossagok.html (2015. augusztus 1.)

188) Origo: Tárki: A magyarok többsége nem akarja, hogy cigányokkal barátkozzon a gyereke. 2011. http://www.origo.hu/itthon/20111205-a-tarki-felmerese-azidegengyuloletrol.html (2015. augusztus 11.)

189) Pap András László: „Overruling Murphy’s law on the free choice of identity and the racial-ethnic-national terminology-triad: Notes on how the legal and political conceptualization of minority communities and membership boundaries is induced by the groups' claims" in Kristin Henrard (szerk.): The interrelation between the right to identity of Minorities and their Socio-economic Participation, Leiden - Boston: Brill, 2013. 115-155.

190) Paul Iganski - Sporidoula Lagou: "How Hate Crimes Hurt More: Evidence from the British Crime Survey" in Barbara Perry and Paul Iganski (szerk.): Hate Crimes: The Consequences of Hate Crime, Vol 2. Westport: Praeger, 2009. 1-13.

191) Paul Iganski: „Regional overviews. Europe” in Peter Grant (szerk.): State of the World's Minorities and Indigenous People 2014. Minority Rights Group International. 162-187.

192) Paul Iganski: Racist Violence in Europe, Brussels, 2011. http://enarireland.org/wp-content/uploads/2013/07/Racist-Violence-in-Europe.pdf (2015. március 7.)

193) Paul L. Wachtel: Race in the Mind of America: Breaking the Vicious Circle Between Blacks and Whites. New York: Routledge. 1999.

194) PET: Crimes motivated by extremism. https://www.pet.dk/English/Counter\%20extremism/Crimes\%20motivated\%20by \%20extremism.aspx (2014. június 9.)

195) Philip Rosen:

Hate propaganda. 2000. http://www.parl.gc.ca/Content/LOP/researchpublications/856-e.htm (2014. október 5.)

196) Police Scotland: Specialist Crime Division. http://www.scotland.police.uk/aboutus/police-scotland/specialistcrime-division/ (2014. szeptember 8.) 
197) PSNI: Equality, Diversity and Good Relations Strategy 2012-2017. http://www.psni.police.uk/equality_diversity_good_relations_strategy.pdf (2014. szeptember 7.)

198) Ralf Michaels: „The Functional Method of Comparative Law” in Mathias Reimann-Reinhard Zimmermann (szerk.): The Oxford Handbook of Comparative Law, Oxford: Oxford University Press, 2006. 339-382.

199) Ralf Michaels: „The Functional Method of Comparative Law” in Mathias Reimann-Reinhard Zimmermann (szerk.): The Oxford Handbook of Comparative Law, Oxford: Oxford University Press, 2006. 339-382.

200) Report by Nils Muižnieks Commissioner for Human Rights of the Council of Europe Following His Visit to Hungary from 1 to 4 July 2014. CommDH(2014)21, Strasbourg, $16 \quad$ December 2014. https://wcd.coe.int/com.instranet.InstraServlet?command=com.instranet.CmdBlob Get $\&$ InstranetImage $=2662996 \&$ SecMode $=1 \&$ DocId $=2218468 \&$ Usage $=2 \quad(2015$. február 9.)

201) Report of the UN High Commissioner for Human Rights, A/HRC/19/41 (nineteenth session, 2011) Discriminatory laws and practices and acts of violence against individuals based on their sexual orientation and gender identity. http://www2.ohchr.org/english/bodies/hrcouncil/docs/19session/A.HRC.19.41_En glish.pdf (2014. február 19.)

202) Richard A. Berk - Elizabeth A. Boyd - Karl M. Hamner: „Thinking More Clearly About Hate-Motivated Crimes" in Barbara Perry (szerk.): Hate and Bias Crime, A Reader. New York: Routledge, 2003, 49-60.

203) Romagyilkosságok: társadalmi tanulságok címü, Setét Jenővel és Zolnay Jánossal folytatott beszélgetés. RTL Magyarul Baló című műsor. 2015. április 14. http://rtl.hu/rtl2/magyarul/romagyilkossagok-tarsadalmi-tanulsagok $(2015$. augusztus 2.)

204) Sara Steen - Mark A. Cohen: “Assessing the Public's Demand for Hate Crime Penalties" Justice Quarterly, 2004/1. 91-124.

205) Sarah Chapman: „Canada Recruits British Police Officers” Toronto News and Views. http://torontonews.wordpress.com/2007/12/31/uk-policemen-enticed-tocanada/ (2014. október 29.)

206) Scottish Police Authority: Specialist Crime Division launches. 2013. http://www.spa.police.uk/news/2013/march/183240/ (2014. szeptember 7.) 
207) Sentencing Council: Crown Court Sentencing Survey http://sentencingcouncil.judiciary.gov.uk/facts/sentencing-survey.htm (2014. november 6.)

208) Sentencing Guidelines Council: Overarching Principles: Seriousness. 2004. https://www.sentencingcouncil.org.uk/wpcontent/uploads/web_seriousness_guideline.pdf (2014. szeptember 8.)

209) Shea W. Cronin [et al.]: „Uncertainty, and Infrequency in Eight Police Departments Bias-Crime Reporting: Organizational Responses to Ambiguity" American Behavioral Scientist, Vol. 51. 2007. 213-231.

210) Szabó András: Recepció és kreativitás a büntetőjogban. http://www.philinst.hu/recepcio/htm/7/704.htm (2015. május 5.)

211) Szajbély Katalin - Tóth Judit: Kisebbségvédelem az Európai Unióban, Kisebbségkutatás, $2002 / 2$. http://www.hhrf.org/kisebbsegkutatas/kk_2002_02/cikk.php?id=1134 (2014. február 12.)

212) Szomora Zsolt: „Dogmatikai és alkotmányjogi megjegyzések a gyülöletbüncselekmények büntetőjogi szabályozásához” Belügyi Szemle, 2013/12. 36-51.

213) Tábori Zoltán: Cigány rulett, Budapest: Európa Könyvkiadó, 2014.

214) Tárki: Továbbra is erős roma-ellenes elöitéletek. 2006. http://www.tarki.hu/tarkitekinto/20060201.html (2015. augusztus 7.)

215) Társaság a Szabadságjogokért: A bírósás megtette dolgát, az állam még tétlenkedik, 2013. augusztus 6. http://tasz.hu/romaprogram/birosag-megtettedolgat-az-allam-meg-tetlenkedik-0 (2014. december 6.)

216) TASZ: A Társaság a Szabadságjogokért álláspontja a gyülölet-büncselekmények szabályozásáról. 2015. 2 http://tasz.hu/files/tasz/imce/tasz-gybcs-allaspontfinal_.pdf (2015. június 2.)

217) TASZ: Miskolci itélet: az ügyészség nem bizonyította a magyarellenes inditékot. http://tasz.hu/romaprogram/miskolci-itelet-az-ugyeszseg-nem-bizonyitottamagyarellenes-inditekot (2013. december 5.)

218) Ténymegállapító vizsgálati jelentés. A romák sérelmére elkövetett sorozatgyilkosság felderitésére irányuló nyomozást segítő nemzetbiztonsági szolgálati munka értékelése az Országgyülés Nemzetbiztonsági Bizottsága által felállított Tényfeltáró Munkacsoport vizsgálati munkája alapján. 2009. 
http://www.parlament.hu/internet/plsql/ogy_biz.keret_frissit?p_szerv=\&p_fomen u=20\&p_almenu=26\&p_ckl=38\&p_biz=A277\&p_rec=\&p_egys $=\& p \_n y e l v=H U$ (2015. július 25.)

219) The City of Calgary: Overview of Standards for Hate/Bias Crime Reporting and Investigation. 2008. http://www.albertahatecrimes.ca/09/images/file/Documents/Resources/Overview $\% 20$ of $\% 20$ Standards $\% 20$ for $\% 20 \mathrm{Hate} \% 20 \mathrm{Bias} \% 20 \mathrm{Crime} \% 20 \mathrm{Reporting} \% 20$ and $\%$ 20Investigation.pdf (2014. augusztus 7.)

220) The New York Times: A Better Response to Hate Crimes. June 8, 1991. www.nytimes.com/1991/06/08/opinion/a-better-response-to-hate-crimes.html (2014. október 2.)

221) Tim J. Berard: „Hate Crimes and Their Criminalization” Research in Social Problems and Public Policy, 2010/17. 15-40.

222) Tóth Mihály: "A dolog elleni erőszak fogalmának értékelése a gyakorlatban" Belügyi szemle, 1981/12. 29-32.

223) Tóth Mihály: “Gondolatok az »erőszak« büntetőjogi fogalmáról” Magyar Jog, 1981/6. 502-511.

224) UNESCO: Four Statements on the Race Questions, 1969. unesdoc.unesco.org/images/0012/001229/122962eo.pdf (2014. szeptember 3.)

225) Uszkiewicz Erik: „Mit (nem) mutatnak a számok?” Belügyi szemle, 2013/12. 8491.

226) Utasi Judit: „A gyülöletbünözés háttere” Kriminológiai Tanulmányok, 48. kötet 2011. 115-126.

227) Vas Népe Online: Elözetesben a romagyilkosságok gyanúsítottjai - Tagadják a büncselekmény elkövetését. 2009. http://vaol.hu/cimlapon/elozetesben-aromagyilkossagok-gyanusitottjai-tagadjak-a-buncselekmenyek-elkovetesetfotoval-1446317 (2015. július 28.)

228) Violence Prevention Network: Taking Responsibility - Breaking Away from Hate and Violence. http://www.violence-prevention-network.de (2014. augusztus 4.)

229) Wayne Sandholtz: „Humanitarian Intervention: Global Enforcement of Human Rights?” in Alison Brysk (szerk.): Globalization and Human Rights. Berkeley: University of California Press, 2002. 201-225. 
230) What happened in Ferguson? New York Times, 2014. november. http://www.nytimes.com/interactive/2014/08/13/us/ferguson-missouri-townunder-siege-after-police-shooting.html?_r=0 (2015. január 14.)

231) Wiener A. Imre: Elméleti alapok a Büntetötörvény Általános Része kodifikálásához, MTA Jogtudományi Intézetének kiadványa, Budapest, 2000. 9697.

\section{Joganyag, joggyakorlat:}

1) 16/2007. (ÜK. 12.) LÜ utasítás a Vádképviseleti Informatikai rendszer bevezetéséről

2) 18/2011. (IX. 23.) ORFK utasítás a Robotzsaru integrált ügyviteli, ügyfeldolgozó és elektronikus iratkezelő rendszer egységes és kötelező használatáról, jogosultsági rendjéről, az adatvédelem, valamint a rendszerfejlesztés előírásairól

3) 1961. évi V. törvény a Magyar Népköztársaság Büntető Törvénykönyvéről (1961es Btk.).

4) 1978. évi IV. törvény a Büntető Törvénykönyvről (1978. évi Btk.).

5) 2002. évi III. törvény az Európa Tanács keretében, 1997. november 6-án kelt, az állampolgárságról szóló Európai Egyezmény kihirdetéséröl www.complex.hu/kzldat/t0200003.htm/t0200003.htm (2014. május 8.)

6) 2012. évi C. törvény a Büntető Törvénykönyvről (Btk.).

7) 2012. évi II. törvény a szabálysértésekről, a szabálysértési eljárásról és a szabálysértési nyilvántartási rendszerről

8) 25/2013 (VI. 24.) BM rendelet a Rendőrség nyomozó hatóságainak hatásköréről és illetékességéről

9) 3/2013. számú BJE határozat

10) 55/2001. (XI. 29.) AB határozat, ABH 2001, 442-477.

11) 56. BK vélemény a büntetéskiszabás során értékelhető tényezőkről

12) 9/1990. (IV. 25.) AB határozat, ABH 1990, 46-49.

13) 96/2008. (VII. 3.) AB határozat, ABH 2008, 816-837.

14) A fogyatékossággal élő személyek jogairól szóló egyezmény (Convention on the Rights of Persons with Disabilities) A/61/611 (Magyarországon kihirdette a 2007. 
évi XCII. törvény.)

15) A Magyar Népköztársaság Büntető Törvénykönyve. Budapest: KJK, 1962. 245.

16) A Miniszteri Bizottság $\mathrm{CM} / \operatorname{REC}(2010) 5$. sz. ajánlása a tagállamok felé $a$ szexuális irányultság, illetve nemi identitás alapján történő diszkrimináció leküzdését célzó intézkedésekröl (Recommendation CM/Rec(2010)5of the Committee of Ministers to member stateson measures to combat discrimination on grounds of sexual orientation or gender identity)1081st meeting of the Ministers' Deputies, 2010. http://www.kormany.hu/download/3/8d/80000/CM-Rec-2010-5ajanlas.pdf (2014. február 16.)

17) A nőkkel szembeni megkülönböztetés minden formájának felszámolásáról szóló egyezmény (Convention on the Elimination of All Forms of Discrimination against Women), U.N.T.S. Vol. 1249, 1979, 13. (Magyarországon kihirdette az 1982. évi 10. törvényerejü rendelet.)

18) A Tanács 1035/97/EK rendelete a Rasszizmus és Idegengyülölet Európai Megfigyelöközpontjának létrehozásáról [Council Regulation (EC) No 1035/97 establishing a European Monitoring Centre on Racism and Xenophobia] HL L 151 ,

http://eur-

lex.europa.eu/LexUriServ/LexUriServ.do?uri=OJ:L:1997:151:0001:001:HU:HT ML (2014. február 17.)

19) A Tanács 168/2007/EK rendelete az Európai Unió Alapjogi Ügynökségének létrehozásáról [Council Regulation (EC) No. 168/2007 establishing a European Union Agency for Fundamental Rights] HL L 53/1, 2007.2.22. http://fra.europa.eu/sites/default/files/fra_uploads/351-reg_168-2007_hu.pdf (2014. február 25.)

20) A Tanács 2000/43/EK irányelve a személyek közötti, faji- vagy etnikai származásra való tekintet nélküli egyenlő bánásmód elvének alkalmazásáról (Council Directive 2000/43/EC Implementing the principle of equal treatment between persons irrespective of racial or ethnic origin) HL L 180, 2000.07.19. http://eur-

lex.europa.eu/LexUriServ/LexUriServ.do?uri=CELEX:32000L0043:hu:HTML (2014. február 16.)

21) A Tanács 2008/913/IB kerethatározata a rasszizmus és az idegengyülölet egyes formái és megnyilvánulásai elleni, büntetőjogi eszközökkel történö küzdelemröl (Council Framework Decision 2008/913/JHA on combating certain forms of 
expressions of racism and xenophobia by means of criminal law) HL L 328, 2008.12.16.

http://eur-

lex.europa.eu/LexUriServ/LexUriServ.do?uri=CELEX:32008F0913:HU:HTML (2014. február 12.)

22) Az Európa Tanács Parlamenti Közgyülése 1735 (2006) sz. ajánlása, A „,nemzet” fogalma, 2. www.mtaki.hu/data/files/208.pdf (2014. április 29.)

23) Az Európai Parlament állásfoglalása a rasszista és homofób eröszak fokozódásáról Európában (European Parliament resolution on the increase in racist and homophobic violence in Europe) P6_TA(2006)0273, 2006. http://www.europarl.europa.eu/sides/getDoc.do?pubRef=//EP//NONSGML+TA+P6-TA-2006-0273+0+DOC+PDF+V0//HU (2014. február 18.)

24) Az Európai Parlament és a Tanács 1922/2006/EK rendelete a Nemek Közötti Egyenlöség Európai Intézetének létrehozásáról [Regulation (EC) No 1922/2006 of the European Parliament and of the Council establishing a European Institute for Gender Equality] HL L 403, 2006.12.30. http://eurlex.europa.eu/LexUriServ/LexUriServ.do?uri=OJ:L:2006:403:0009:0017:HU:PD F (2014. március 31.)

25) Az Európai Parlament és a Tanács 2012/29/EU irányelve a büncselekmények áldozatainak jogaira, támogatására és védelmére vonatkozó minimumszabályok megállapításáról és a 2001/220/IB tanácsi kerethatározat felváltásáról (Directive 2012/29/EU of the European Parliament and of the Council establishing minimum standards on the rights, support and protection of victims of crime, and replacing Council Framework Decision 2001/220/JHA) HL L 315/57, 2012.11.14. http://eur-

lex.europa.eu/LexUriServ/LexUriServ.do?uri=OJ:L:2012:315:0057:0073:HU:PD F (2014. február 17.)

26) Az Európai Unió működéséről szóló szerződés egységes szerkezetbe foglalt változata (Treaty on the Functioning of the European Union) HL C 326/47, 2012.10.26. http://eurlex.europa.eu/LexUriServ/LexUriServ.do?uri=OJ:C:2012:326:0047:0200:HU:PD F (2014. február 28.)

27) BH 1980. 116.

28) BH 1981. 489. 
29) BH 1983. 177.

30) BH 1985.291.

31) BH 1987. 177.

32) BH 1990. 326.

33) $\mathrm{BH} 1994.646$.

34) BH 1999. 53.

35) BH 2000. 185.

36) BH 2000. 186

37) BH 2004. 269.

38) $\mathrm{BH} 2007.283$.

39) $\mathrm{BH} 2009.171$.

40) BH. 1982. 74.

41) BJE 3/2011. szám

42) Budapesti VI. és VII. kerületi Ügyészség, B. VI-VII. 3541/2012/2.

43) Büntető Törvénykönyv. Budapest: KJK, 1979, 215.

$\begin{array}{lllll}\text { 44) Crime } & \text { and } & \text { Disorder } & \text { Act }\end{array}$ http://www.legislation.gov.uk/ukpga/1998/37/part/II (2014. június 15.)

45) Criminal Justice Act 2003 http://www.legislation.gov.uk/ukpga/2003/44/pdfs/ukpga_20030044_en.pdf

46) Criminal Law (Consolidation) (Scotland) Act 1995 50/A. http://www.legislation.gov.uk/ukpga/1995/39/section/50A (2014. október 29.)

47) Debreceni Törvényszék, 25.B.48/2013/23. sz.

48) Debreceni Törvényszék, 25.B.48/2013/23. szám.

49) EBESZ/DIEJH: Hate Crime Laws. A Practical Guide.Warsaw, 2009. 50. http://www.osce.org/odihr/36426 (2013. december 3.)

50) ECtHR, Case of Milanović v. Serbia, No. 44614/07, 14 December 2010. http://echr.ketse.com/doc/44614.07-en-20101214/view/ (2014. február 15.)

51) ECtHR, Case of Nachova and Others v. Bulgaria, Nos. 43577/98 and 43579/98, 6 July 2005. http://hudoc.echr.coe.int/sites/eng/pages/search.aspx?i=00169630\#\{"itemid":["001-69630"]\} (2014. február 16.)

52) ECtHR, Case of Šečić v. Croatia, No. 40116/02, 31 August 2007. http://hudoc.echr.coe.int/sites/eng/pages/search.aspx?i=00180711\#\{"itemid":["001-80711"]\} (2014. február 15.) 
53) ECtHR, Case of Smith and Grady v. The United Kingdom, Nos. 33985/96 and 33986/96,

http://hudoc.echr.coe.int/sites/eng/pages/search.aspx $? \mathrm{i}=001$ -

58408\#\{"itemid":["001-58408"]\} (2014. február 14.)

54) ECtHR, Case of Vejdeland and Others v. Sweden, No. 1813/07, 9 August 2012. http://hudoc.echr.coe.int/sites/eng/pages/search.aspx?i=001109046\#\{"itemid":["001-109046"]\} (2014. február 14.)

55) ECtHr, Case of Vona v. Hungary, No. 35943/10, 9 July 2013. http://hudoc.echr.coe.int/sites/eng/pages/search.aspx?i=001122183\#\{"itemid":["001-122183"]\} (2013. november 26.)

56) Egyezmény az emberi jogok és alapvető szabadságok védelméről (European Convention for the Protection of Human Rights and Fundamental Freedoms) E.T.S. No. 005. (Magyarországon kihirdette az 1993. évi XXXI. törvény.)

57) Európai Unió Alapjogi Chartája (Charter of Fundamental Rights of the European Union) HL $\quad$ C $\quad 326 / 391, \quad$ 2012.10.26. http://eurlex.europa.eu/LexUriServ/LexUriServ.do?uri=OJ:C:2012:326:FULL:HU:PDF (2014. március 5.)

58) Joint Declaration by the European Parliament, the Council and the Commission against racism and xenophobia, OJ C 158, 25.6.1986. http://www.europarl.europa.eu/workingpapers/libe/102/text5_en.htm\#annex1 (2014. március 5.)

59) Joint Declaration by the European Parliament, the Council, OJ C 103 1, 27.4.1977.

http://www.europarl.europa.eu/charter/docs/pdf/jointdecl_04_77_en_en.pdf (2014. március 5.)

60) Keretegyezmény a nemzeti kisebbségek védelméről (Framework Convention for the Protection of National Minorities) ETS. No. 157, 1995. (Magyarországon kihirdette az 1999. évi XXXIV. törvény) http://www.hungarian-humanrights.eu/Strasbourgi\%20keretegyezmeny\%20a\%20kisebbsegek\%20vedelmerol\% 201995.pdf (2014. február 19.)

61) Miskolci Járásbíróság (megismételt I. fok) 22. B.2418/2011, Miskolci Törvényszék (megismételt II. fok) 3. Bf. 2023/2012.

62) Miskolci Járásbíróság 22. B. 2418/2011, Miskolci Törvényszék 3. Bf. 2023/2012. 
63) Miskolci Járásbíróság B.1157/2012/95, Miskolci Törvényszék Fkf.1099/2013/10, Debreceni Ítélőtábla Fkhar.248/2014/7.

64) Miskolci Törvényszék Fk.1188/2011/217, Debreceni Ítélőtábla Fkf.498/2013/13, Kúria Bhar.118/2014/11.

65) Miskolci Törvényszék, 14.Fkf.1099/2013/10.

66) Nemzetközi egyezmény a faji alapú hátrányos megkülönböztetés valamennyi formájának kiküszöböléséröl (International Convention on the Elimination of All Forms of Racial Discrimination) U.N.T.S. No. 9464, Vol. 660, 1969, 212. (Magyarországon kihirdette az 1969. évi 8. törvényerejü rendelet.)

67) Nemzetközi egyezmény a kínzás és más kegyetlen, embertelen vagy megalázó büntetések vagy bánásmódok ellen (Convention Against Torture and Other Cruel, Inhuman or Degrading Treatment or Punishment) U.N.T.S. No. 24841, Vol. 1465, 1987, 85. (Magyarországon kihirdette az 1988. évi 3. törvényerejü rendelet.)

68) OSCE Ministerial Council Decision No. 10/05 Tolerance and non-discrimination: promoting mutual respect and understanding, 6 December 2005. http://www.osce.org/mc/17462 (2014. február 18.)

69) OSCE Ministerial Council Decision No. 4/03 Tolerance and non-discrimination, 2 December 2003. http://www.osce.org/mc/19382 (2014. február 18.)

70) OSCE Ministerial Council Decision No. 621 Tolerance and the fight against racism, xenophobia and discrimination, 29 July 2004. http://www.osce.org/pc/35610 (2014. február 18.)

71) OSCE Ministerial Council Decision No. 9/09 Combating hate crimes, 2 December 2009. http://www.osce.org/cio/40695 (2014. február 14.)

72) OSCE Ministerial Council, Decision No. 13/06, Combating Intolerance and Discrimination and Promoting Mutual Respect and Understanding, Brussels, 5 December 2006. http://www.osce.org/mc/23114?download=true (2015. március 7.)

73) Parliamentary Assembly Recommendation 1222 (1993) on the fight against racism, xenophobia and intolerance. http://www.assembly.coe.int//Main.asp?link=http://www.assembly.coe.int/Docum ents/AdoptedText/TA93/EREC1222.HTM (2014. március. 5.)

74) Parliamentary Assembly Recommendation 1275 (1995) on the fight against racism, xenophobia, anti-Semitism and intolerance. 
http://assembly.coe.int/Main.asp?link=/Documents/AdoptedText/ta95/EREC1275. htm (2014. február 12.)

75) Pesti Központi Kerületi Bíróság Fk.27246/2010/83, Fővárosi Törvényszék Fkf.8472/2011/38, Kúria Bfv.590/2012/18.

76) Polgári és Politikai Jogok Nemzetközi Egyezségokmánya (International Covenant on Civil and Political Rights) U.N.T.S. No. 14668, Vol. 999, 1966, 172. (Magyarországon kihirdette az 1976. évi 8. törvényerejü rendelet.)

77) Protocol No. 12 to the Convention for the Protection of Human Rights and Fundamental Freedoms. CETS No.: 177, Rome, 4 November 2000. http://conventions.coe.int/Treaty/en/Treaties/Html/177.htm (2015. február 10.)

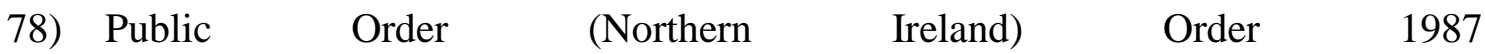
http://www.legislation.gov.uk/asp/2009/8/contents (2014. október 29.)

79) R. v. Baxter, [1997] O.J. No. 5811 (Prov. Div.)

80) R. v. Miloszewski [1999], B.C.J. No. 2710 (Prov. Ct.)

81) R. v. Sandouga, [2002] A.J. No. 1042 (C.A.)

82) Resolution of the European Parliament on racism, xenophobia, and anti-semitism, OJ C 323/154, 20.11.1994 and Resolution of the European Parliament on racism, xenophobia and anti-semitism, OJ C 308/140, 20.11.1995. http://www.europarl.europa.eu/workingpapers/libe/102/text5_en.htm\#annex1 (2014. március 5.)

83) T/2990. számú törvényjavaslat a Büntető Törvénykönyvről szóló 1978. évi IV. törvény módosításáról szóló

84) T/6218. számú törvényjavaslat a közrend, valamint az igazságszolgáltatás müködésének védelme érdekében szükséges egyes törvénymódosításokról

85) T/6958. számú törvényjavaslat a Büntető Törvénykönyvről

86) The Criminal Code of Finland. www.finlex.fi/en/laki/kaannokset/1889/en18890039.pdf.

87) UN CAT General Comment 2, U.N. Doc. CAT/C/GC/2/CRP. 1/Rev.4. (thirtyninth session, 2007), Implementation of article 2 by States Parties. http://www1.umn.edu/humanrts/cat/general_comments/cat-gencom2.html (2014. február 17.)

88) UN CEDAW General Recommendation No. 19 (eleventh session, 1992), Violence against women. 
http://www.un.org/womenwatch/daw/cedaw/recommendations/recomm.htm (2014. február 19.)

89) UN CERD Communication No. 46/2009 (eightieth session, 2012), Dawas and Shava

Denmark.http://www2.ohchr.org/english/bodies/cerd/docs/jurisprudence/CERD-

C-80-D-46-2009_en.pdf (2014. február 12.)

90) UN CERD General Recommendation No. 25 (fifty-sixth session, 2000) Gender related dimensions of Racial discrimination. http://www.unhchr.ch/tbs/doc.nsf/0/76a293e49a88bd23802568bd00538d83?Open document (2014. február 12.)

91) UN CERD, Communication No. 4/1991 (forty-second session, 1993), L.K. v. The Netherlands.http://www1.umn.edu/humanrts/country/decisions/CERD-DLR.htm (2014. február 17.)

92) UN Human Rights Committee Communication No. 488/1992, Toonen $v$. Australia, 4 April 1994.http://www.unhchr.ch/tbs/doc.nsf/0/d22a00bcd1320c9c80256724005e60d5 (2014. február 12.)

93) UN Human Rights Committee Communication No. 941/2000, Young v. Australia, 18 September 2003. http://www1.umn.edu/humanrts/undocs/941-2000.html (2014. február 12.)

94) UN Human Rights Council, A/HRC/17/19 (seventeenth session, 2011) Human rights, sexual orientation and gender identity. http://daccess-ddsny.un.org/doc/UNDOC/GEN/G11/148/76/PDF/G1114876.pdf?OpenElement (2014. február 17.)

95) UN Human Rights Council, A/HRC/18/17 (eighteenth session, 2011) Report of the Working Group on the Universal Periodic Review Hungary. http://daccessdds-ny.un.org/doc/UNDOC/GEN/G11/145/34/PDF/G1114534.pdf?OpenElement (2014. március 3.)

96) UN Human Rights Council, A/HRC/18/17/Add.1 (Eighteenth session) Report of the Working Group on the Universal Periodic Review. Hungary. Addendum. Views on conclusions and/or recommendations, voluntary commitments and replies presented by the State under review. 14 September 2011. http://www2.ohchr.org/english/bodies/hrcouncil/docs/18session/A-HRC-18-17Add1.pdf (2014. március 3.) 
97) UN Human Rights Council, CCPR/C/79/Add.110 (sixty-sixth session, 1999) Concluding Observations of the Human Rights Committee: Poland, para 23. http://www.unhchr.ch/tbs/doc.nsf/0/a61db0e519524575802567c200595e9c?Open document (2014. február 12.)

98) Veszprém Megyei Rendőr-főkapitányság, Bűnügyi Igazgatóság, Vizsgálati Osztály, 19000/156/2012.bü. sz. határozat. http://helsinki.hu/wpcontent/uploads/Devecser_hatarozat_201309.pdf (2015.július 29.)

99) Wisconsin v. Mitchell, www.law.cornell.edu/supct/html/92-515.ZO.html.

100) Yogyakarta alapelvek: Alapelvek a nemzetközi emberi jogi szabályok alkalmazásáról a szexuális irányultsággal és a nemi identitással kapcsolatban. Háttér Társaság (ford.) 2010 http://ypinaction.org/files/03/30/yogyakarta_hungarian.pdf (2014. május 5.)

101) Zalaegerszegi Járásbíróság B.404/2011/101, Zalaegerszegi Törvényszék Bf.152/2012/5, Pécsi Ítélőtábla Bhar.247/2012/18. 